\title{
14
}

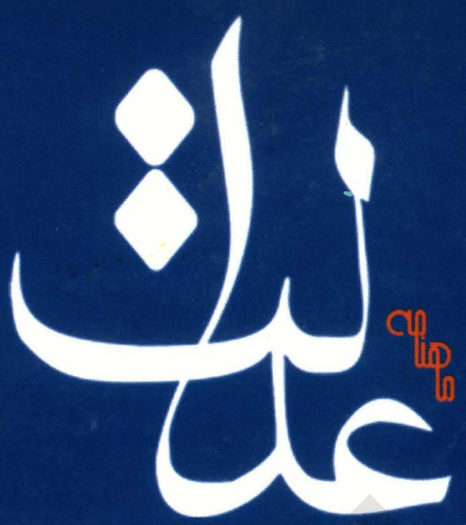

$$
\text { تخدلي وزارت نشر اتى اركّان }
$$

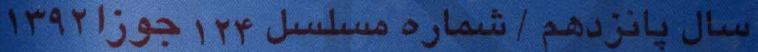




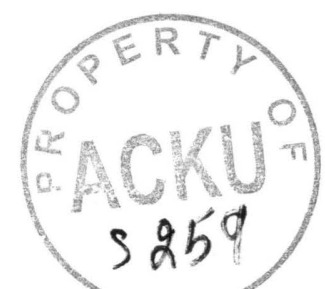

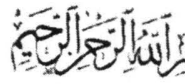

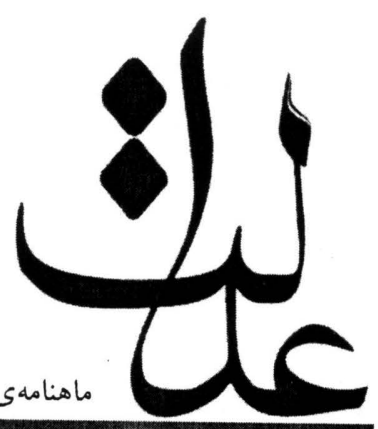

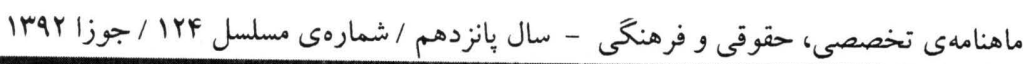

صاحب امتياز

هيأت تحرير:

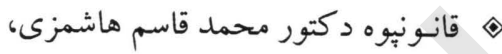

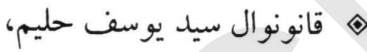

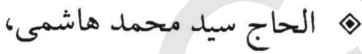
هـ د دور عبدالرؤف هروى، هائ،

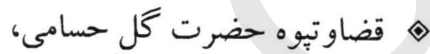

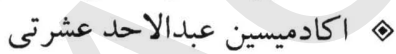
هـ قانونيال عبدالقدير قيومى،

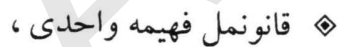
ه

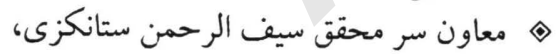
هـ قانونمل محمد رحيم دقيق، ه ه هانيم سروشل محمد،

\section{Website: www.moj.gov.af}

E-mail: adalat@moj.gov.af
وزارت عدليه د. ج ـ 1 .

مدير مسوول

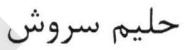

(•VVIT. I9VA)

ويراستار

عبدالقيوم قيومى

ديزاين جلد و صفحه آرايى

كريم قريشى آرايى

امور تايب و حروفجينى

عبدالكريم قريشى و محمد فهيم صادقى تاني

قيمت •ه افغانى 


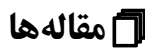

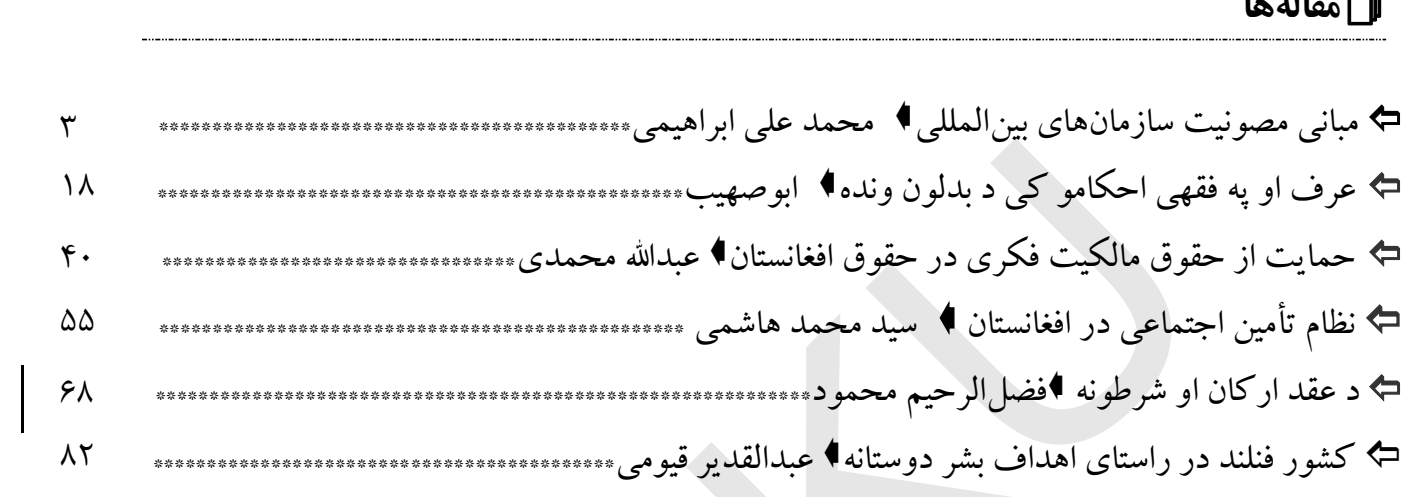

هـ

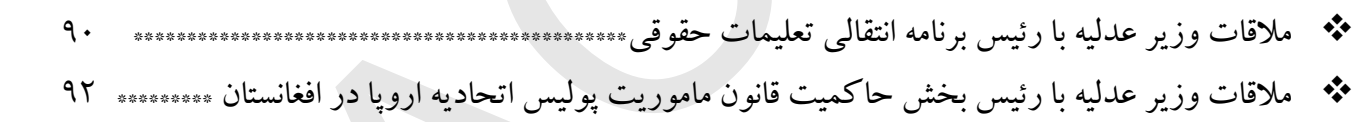




\title{
مبانى مصونيت سازمانهاى بينالمللى
}

\author{
قسمت اول
}

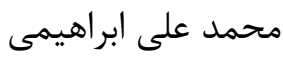

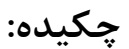

مصونيت سازمانهاى بينالمللى يكى از موضوعات مهام حقوق بينالملل است. در بحث

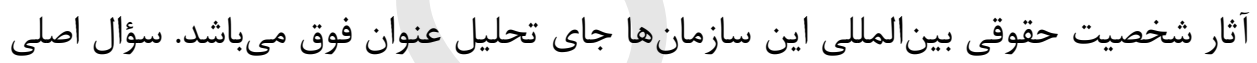

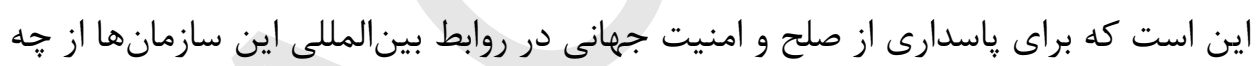

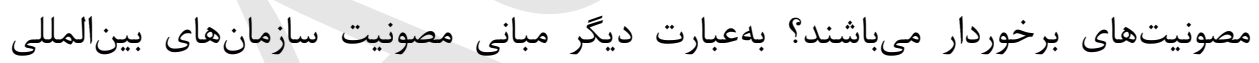

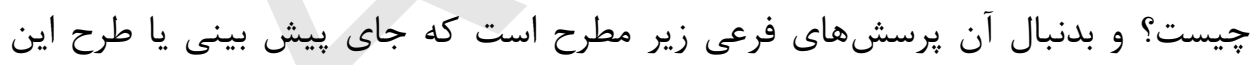

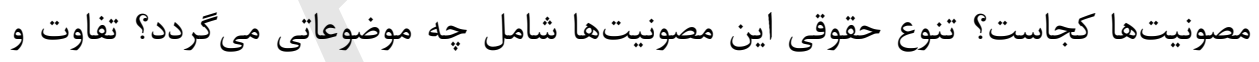

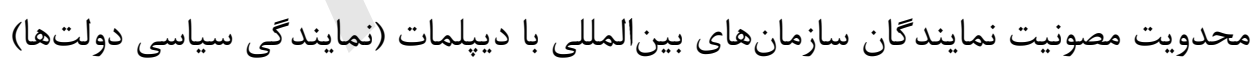
در جيست؟ محدو

يافتن پاسخ يرسش هاى فوق مى طلبد كه تحقيق كتابخانهاى ييرامون عنوان انجام شود تا

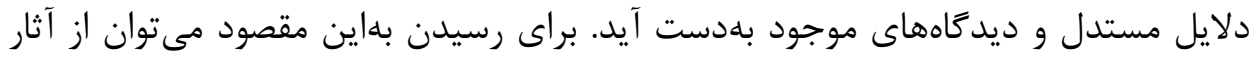

$$
\text { زير كمك كرفت: }
$$

$$
\begin{aligned}
& \text { ا. . در آمدى بر حقوق اسلامى ، يزوهشكاه حوزه و دانشگاه. }
\end{aligned}
$$

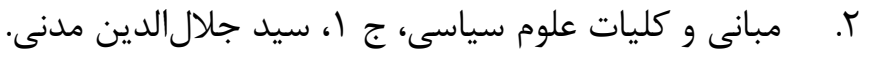


r. نقش اسلام در توسعه حقوق بينالملل، عبدالحكيم سليمى.

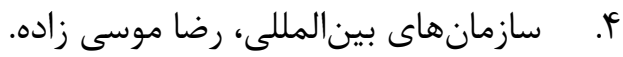

هـ. حقوق سازمانهاى بينالمللى، غفورى. 9. حقوق بينالملل عمومى، ضيايى بيكدلى.

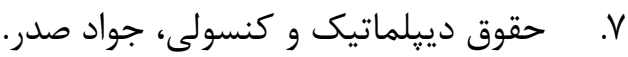

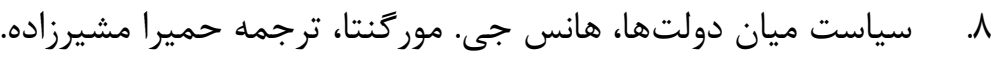
9 9. مبانى تحليل سياست بينالملل، كى جى هالستى، ترجمه بهرام مستقيمى و مسعود طارم سرى. و ... وازگًان كليدى: سازمانهاى بينالمللى، مصونيت، حقوق بينالملل، كنوانسيون و دكترين

\section{() مقدمه}

سازمانهاى بينالمللى يكى از واقعيتهايى است كه با آن مواجه هستيم. بخشى از

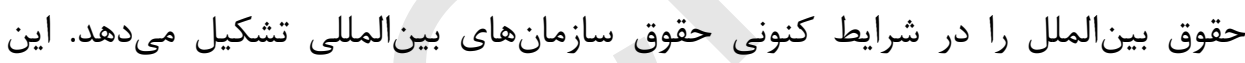

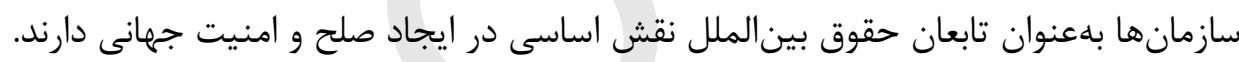

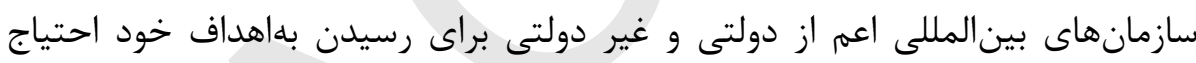

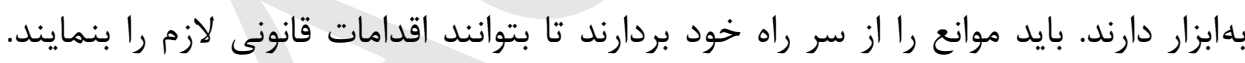

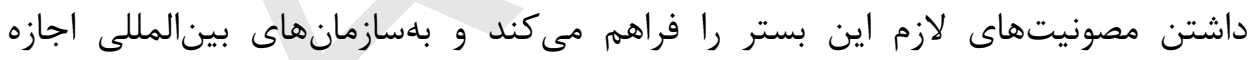

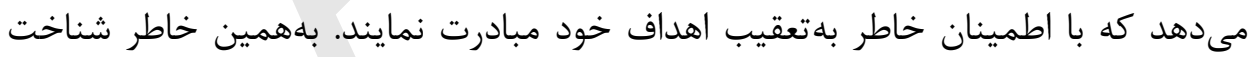

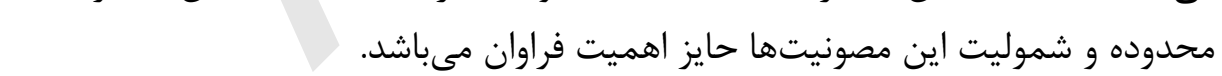

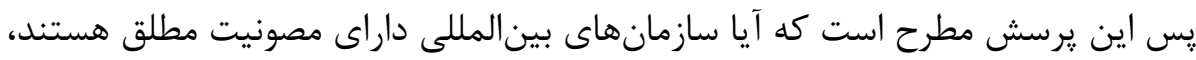

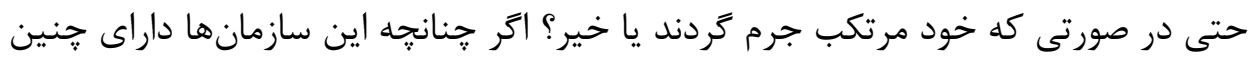

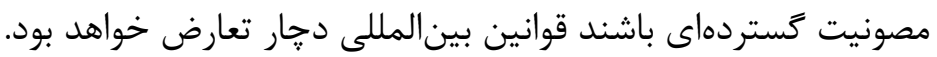

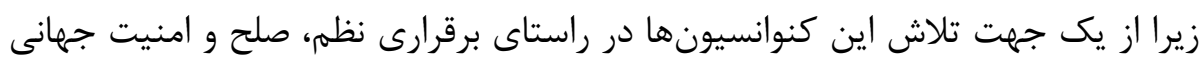

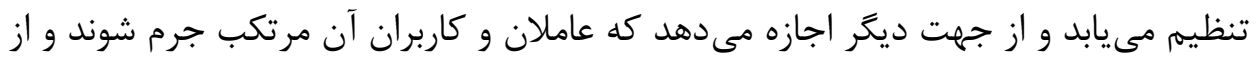


محاكمه عادلانه هم برى و رها باشند. اين تعارض موجب بىاعتبارى تشكلهاى بينالدولى

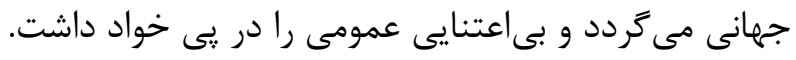

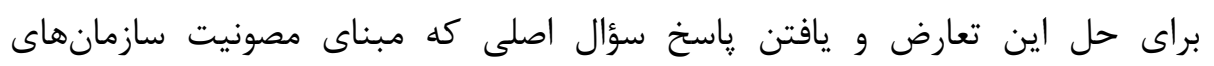

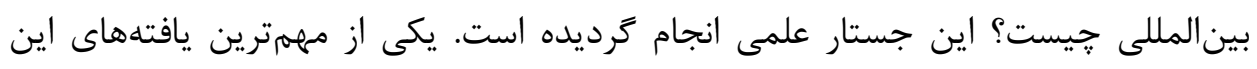

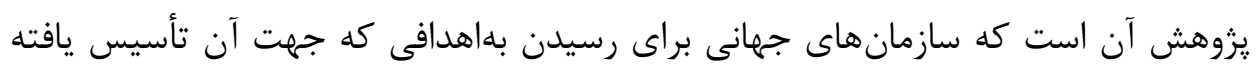

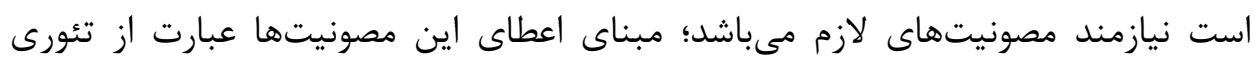

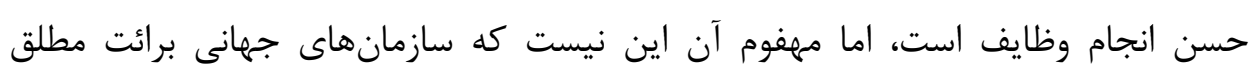

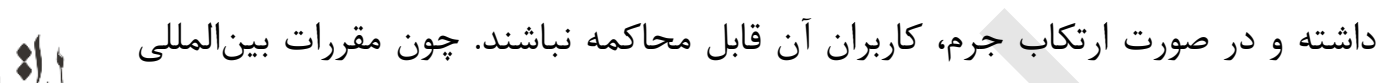

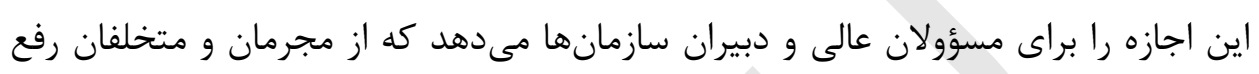

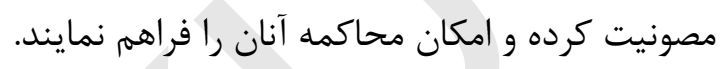

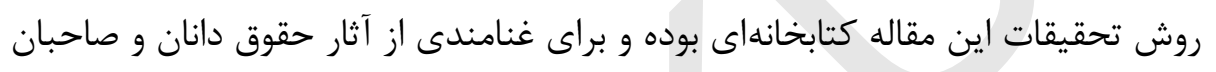

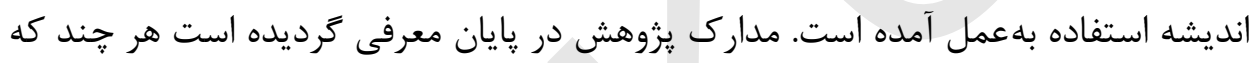
در ياورقى نيز ارجاع لازم داده شده است.

\section{r) كليات مفاهيم}

\section{(}

مبانى از لحاظ ساختار لغوى جمع مبنا است. مبنا در لغت بلمعناى اصل، ريشه، اساس،

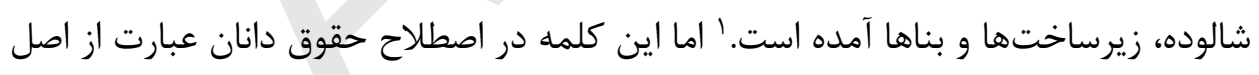

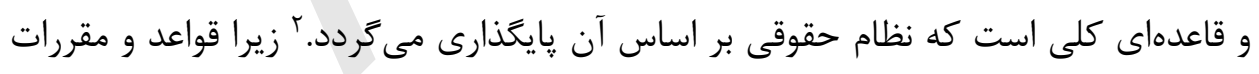

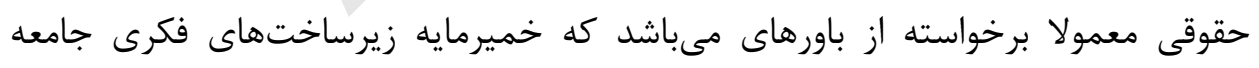

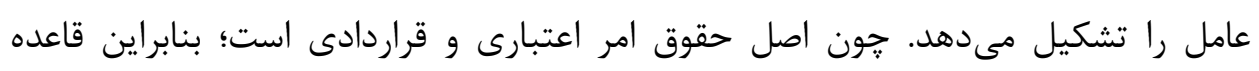

$$
\begin{aligned}
& \text { ' ' انورى، حسين، فرهنغ بزرى سخن، ج ل، حرف ميم. }
\end{aligned}
$$

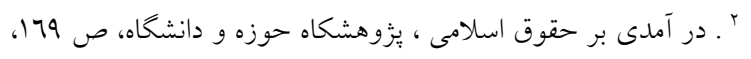


حقوقى اعتباراتى خواهد بود كه ريشه در باورها و اعتقادات مردم دارد. بههمين علت است

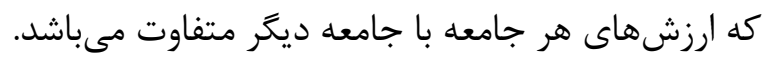

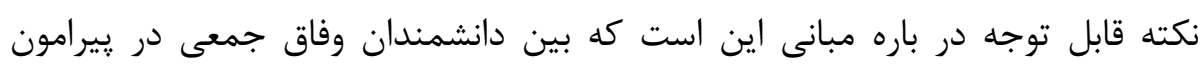

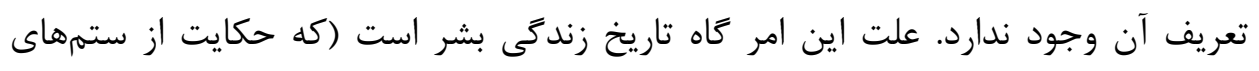

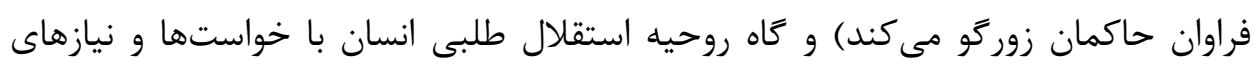

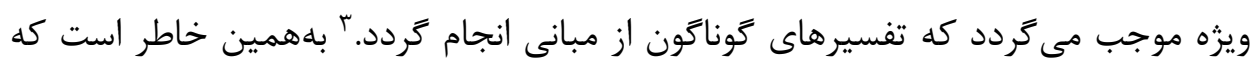

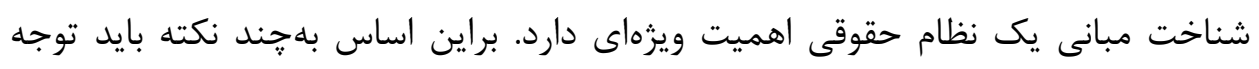

$$
\text { كرد: }
$$

1. محدوديت و توسعه احكام حقوقى، تابع روابط اجتماعى يك جامعه است.

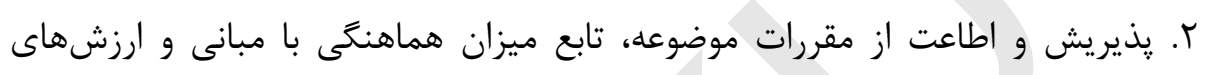
اجتماعى مى باشد. r. يكى از عوامل اختلافات و تعدد نظامهاى حقوقى دنيا عبارت از اختلافات مبانى آنها

$$
\text { با توجه بلموارد فوق مىتوان مبانى را جنين تعريف كرد: }
$$

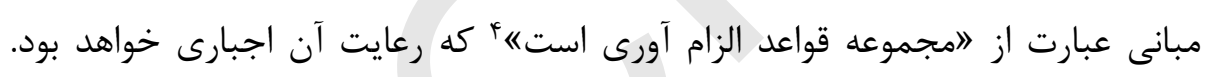

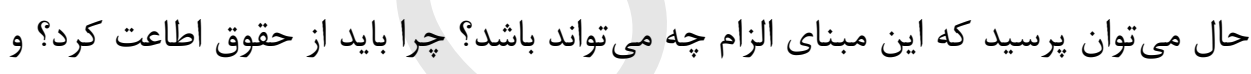

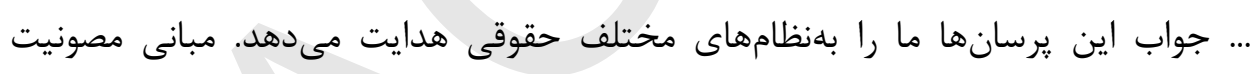

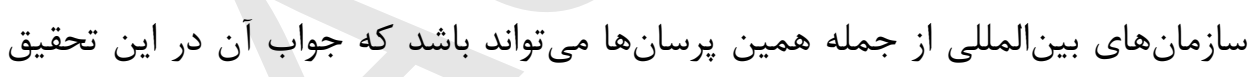

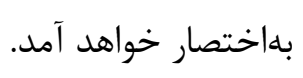

\section{(}

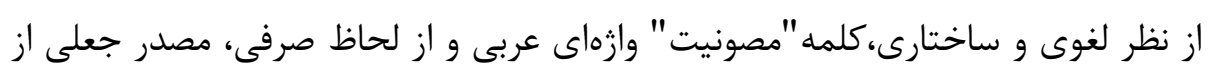

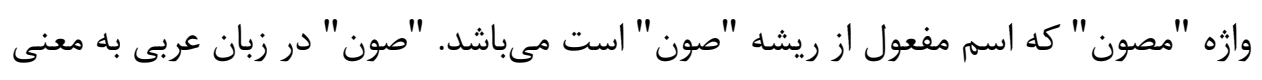


"حفظ كردن" بوده و به جيزى كه مورد محافظت قرار كرفته " مصون" كفتنه مىشوده از از

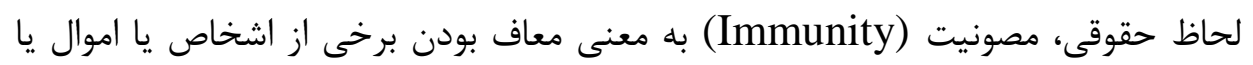
احوال، از قواعد عامه كشور در امور قضايى يا انتظامى يا مالياتى است.

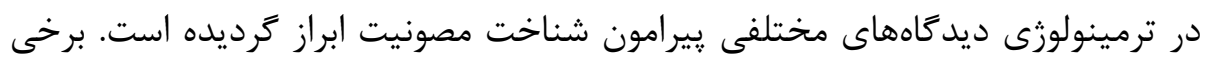

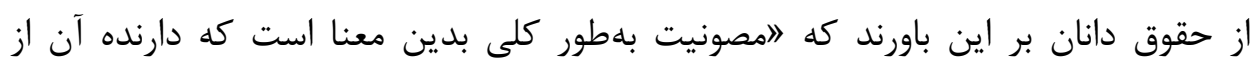

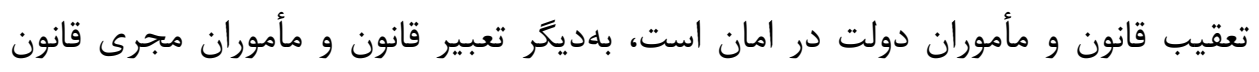

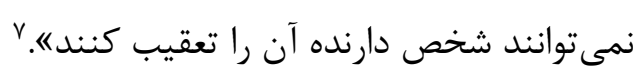

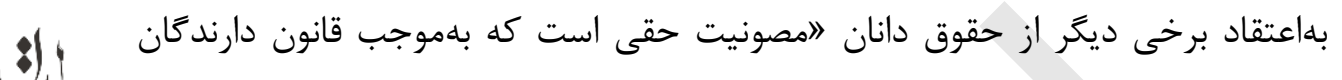

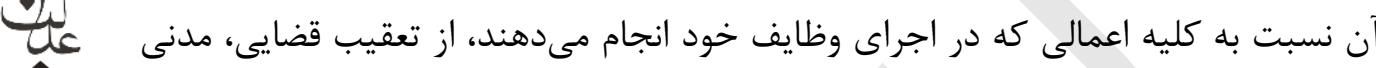

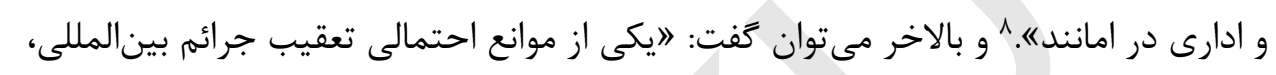

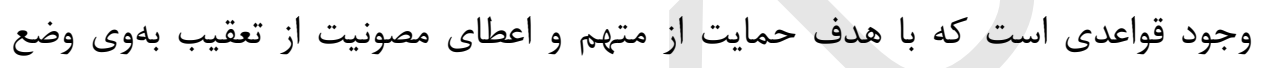

بيت القصيد اين نظر كاهها آن است كه وقتى مصونيت براى اشخاص حقيقى و حقون حقوقى

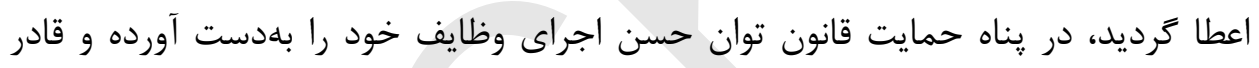

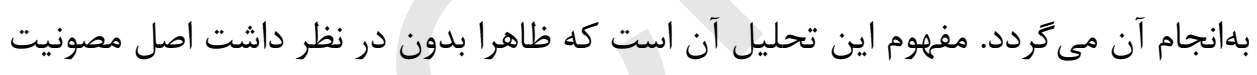

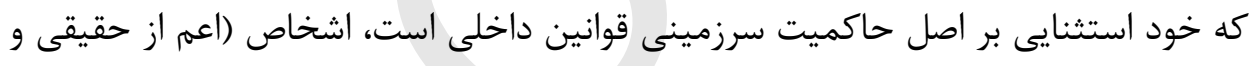

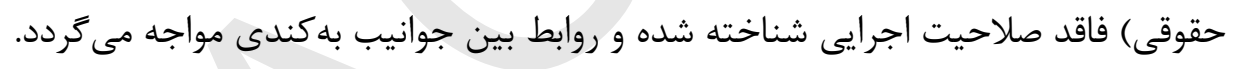

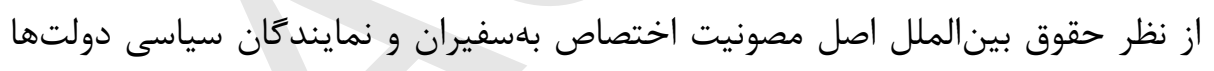

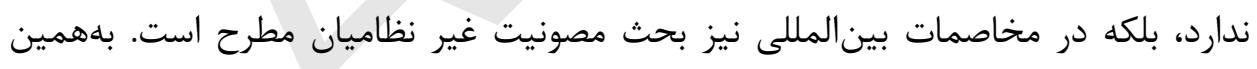

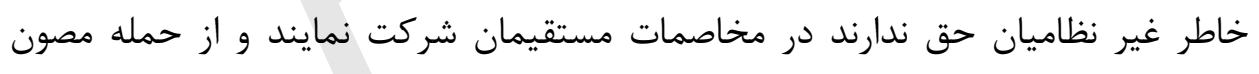

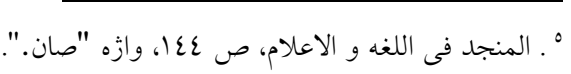

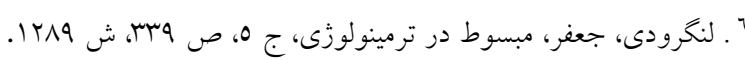

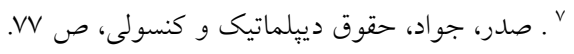

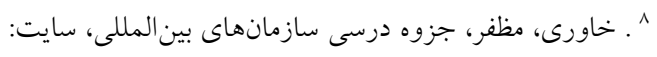

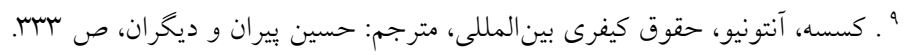


هستند، آنها در صورتى كه مستقيما در حمله شركت نمايند مصونيت را از دست

$$
\text { مى دهند. }
$$

بايد توجه داشت كه موضوع مصونيت يكى از مباحث مهمه حقوق بين الملل عمومى است

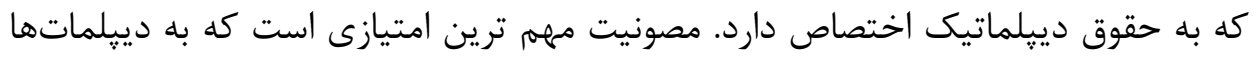

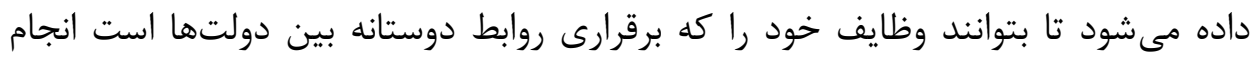

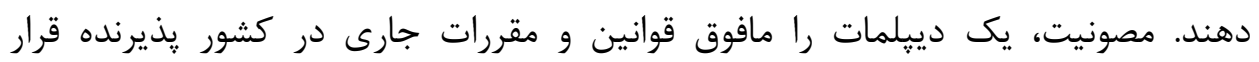

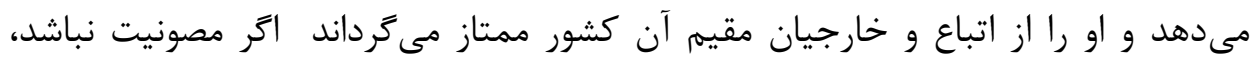

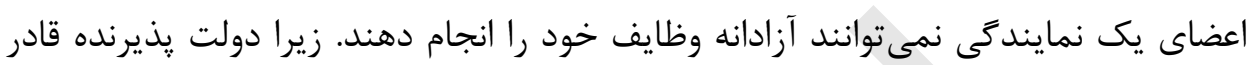

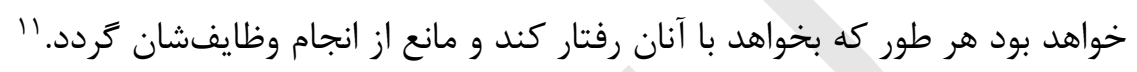

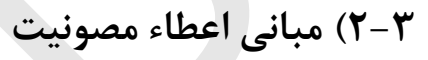

يكى از يرسشهاى اساسى اين است كه مصونيت براى نمايندًان دولتها و سازمان مانهاى

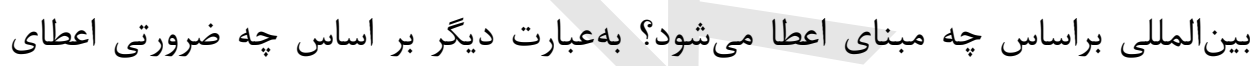

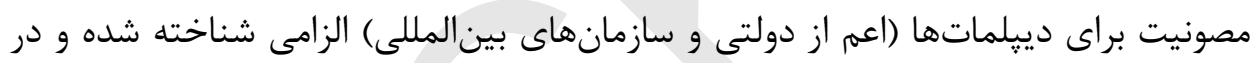

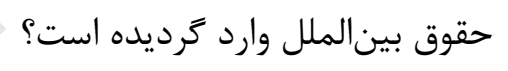

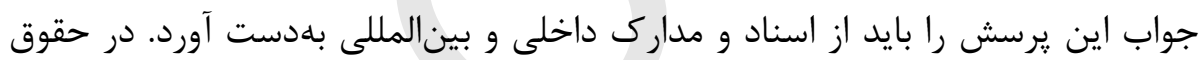

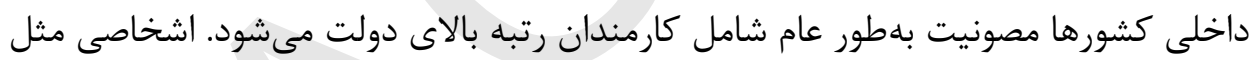

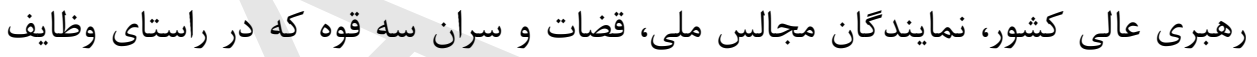

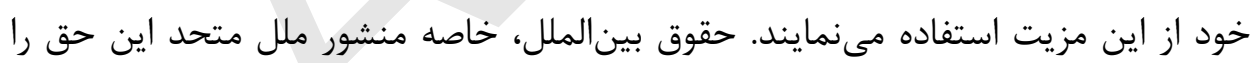

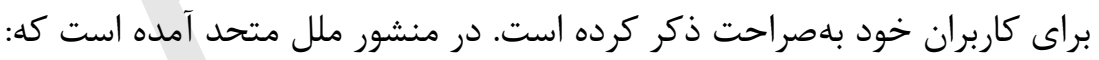

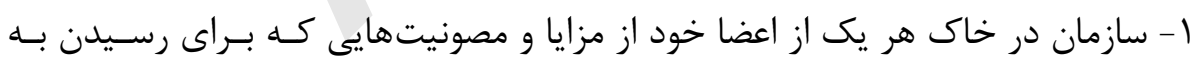

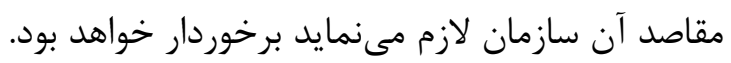

" . آنتونى ٍ.بو. راجرز بِل مالرب، قواعد كاربردى حقوق مخاصمات مسلحانه، ترجمه: كميته ملى حقوق بشر دوستانه، 
آ- نمايندكان اعضاى ملل متحد و كارمندان سازمان نيز از مزايا و مصونيتهايى كه براى

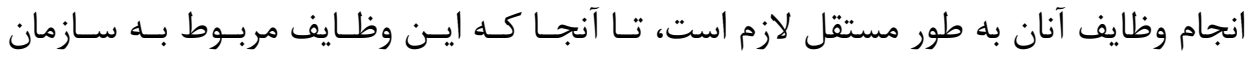

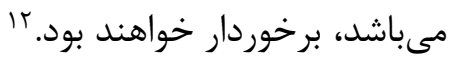

براين اساس توجيه حقوقى اعطاى مصونيت براى كاربران سازمانهاى بران بينالمانللى تفاوت

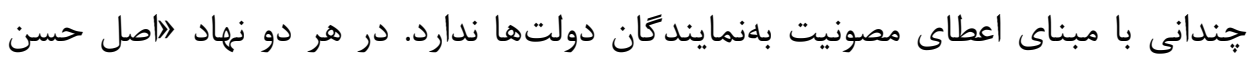

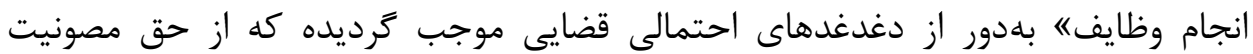

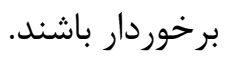

در عين حال درك درست و شناخت اساسى مبناى اعطاى مصونيت اقتضا دارد كه سابقه

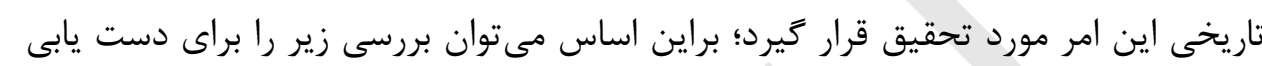
بهاصول كلى مبناى اعطاى مصونيت انجام داد.

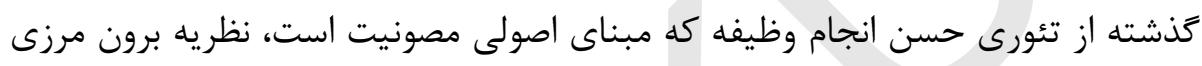

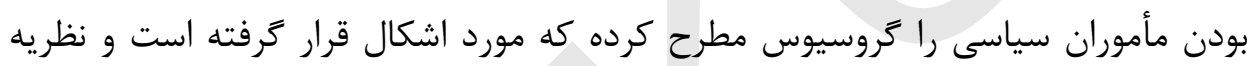

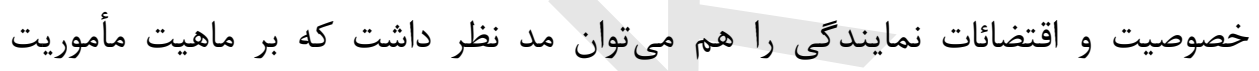

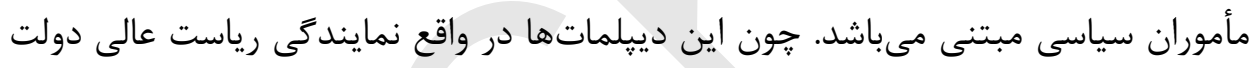

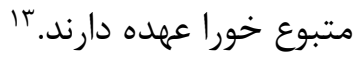

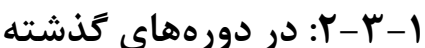

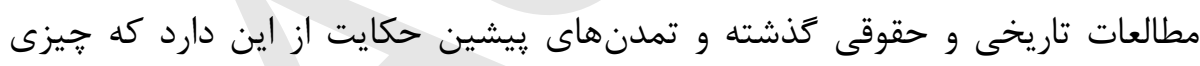

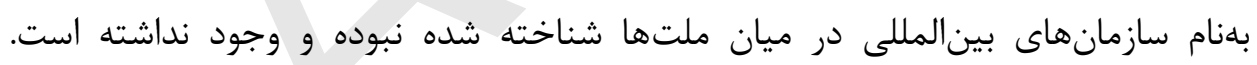

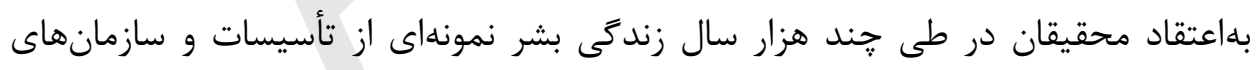

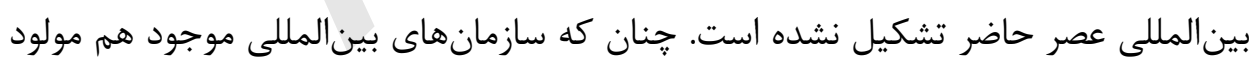

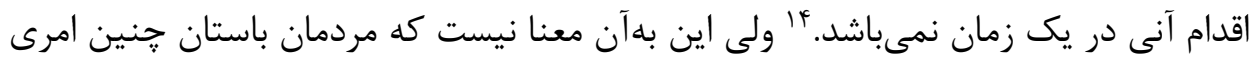

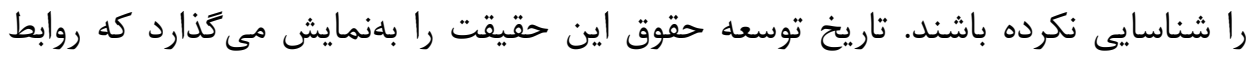

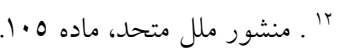

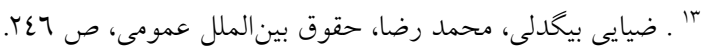

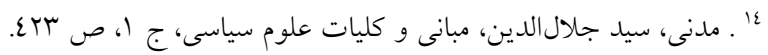


فى مابين دولتها فراز و فرودهاى زيادى داشته است. كشورها از طريق برقرارى روابط سعى

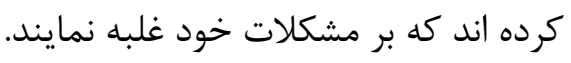

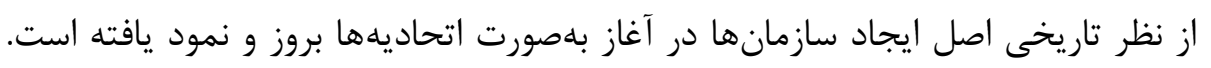

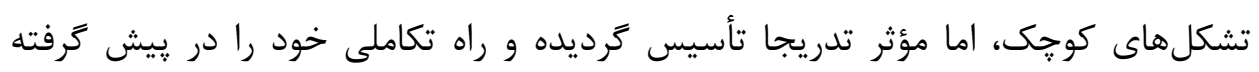

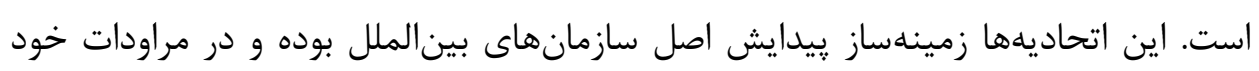

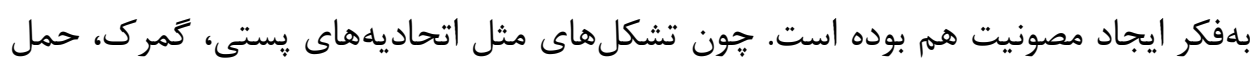

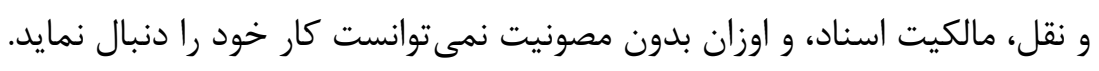

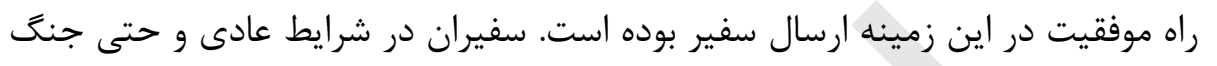

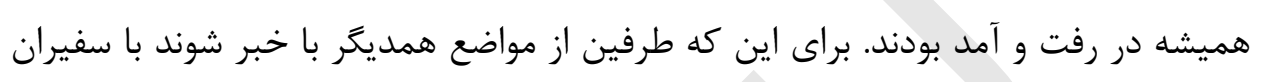

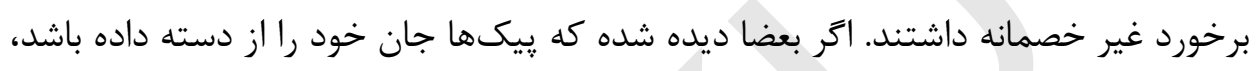

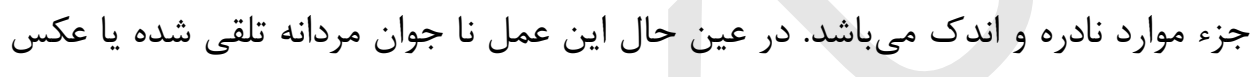

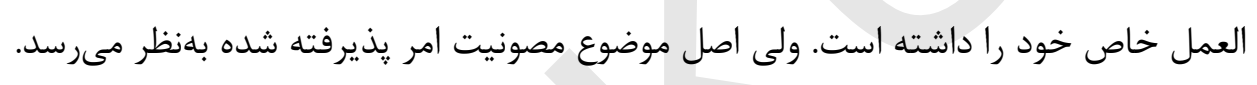

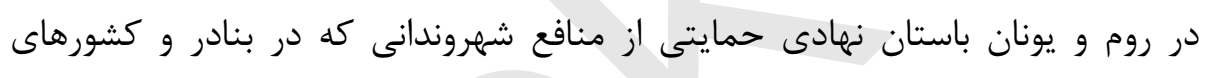

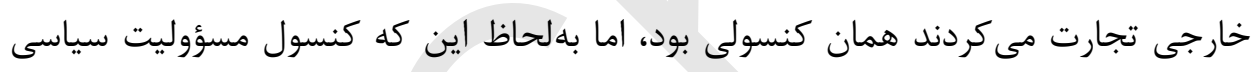

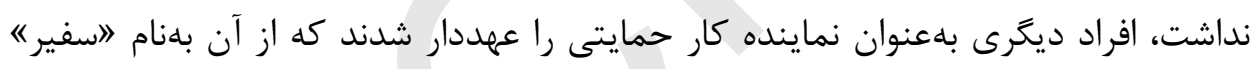

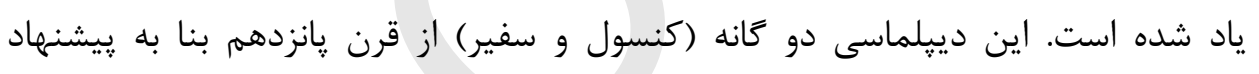

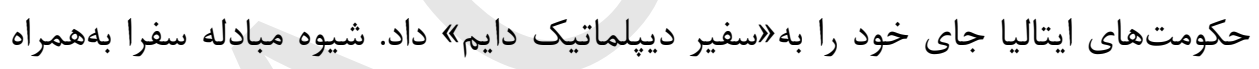

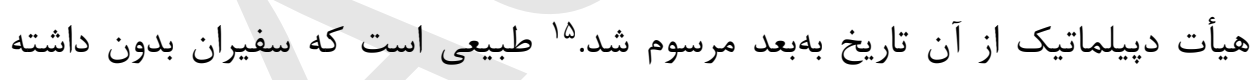
مصونيت از انجام درست وظايف خود باز مىماندند.

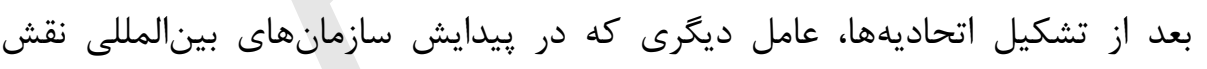

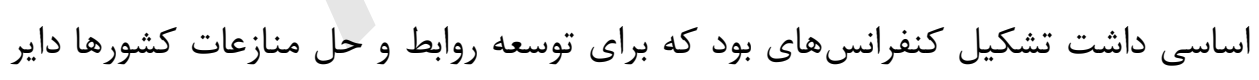

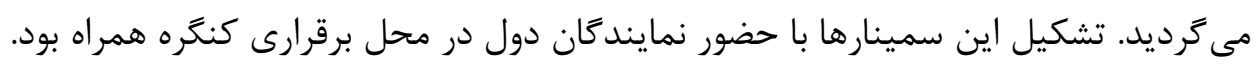

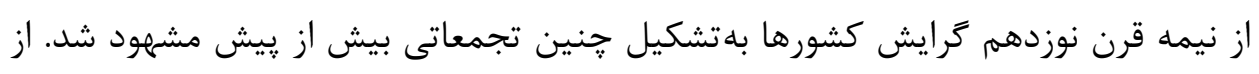

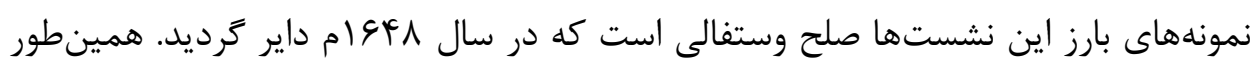

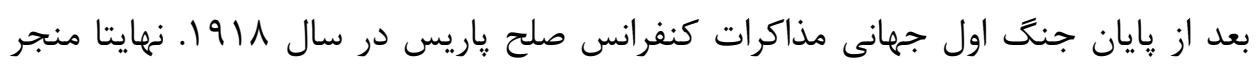

$$
\text { 10 . موسى زاده، رضا، سازمانهاى بين المللى، ص سب. }
$$


بلعانعقاد "امعاهدات ورساى" در سال 919 |م كرديد."1 دستيابى بلنتايج كل اين تلاشها بدون مصونيت امكان يذير نمىبود.

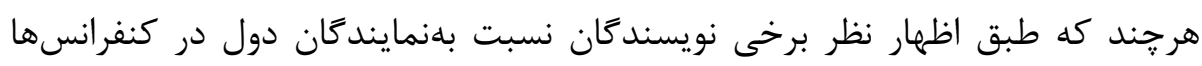

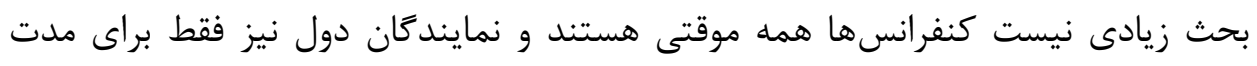

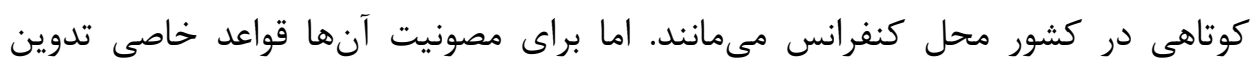

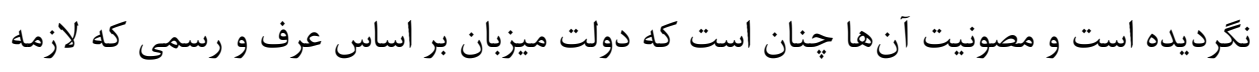

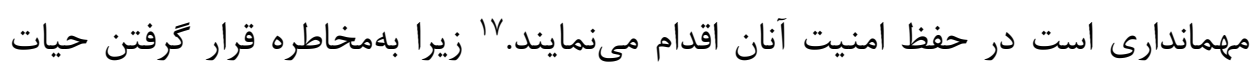
آنان موجب بد نامى ابدى كشور ميزبان مى كردد.

\section{r r-r-r}

همان كون كه كذشت در روزكار قديم مبناى اعطاى اين امتيازات و مصونيتها، نظريهى

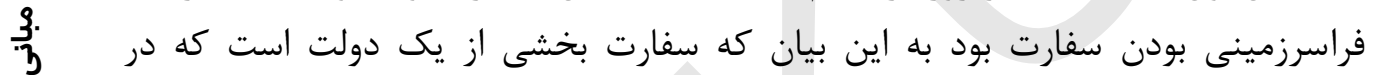

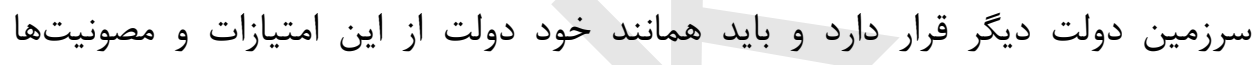

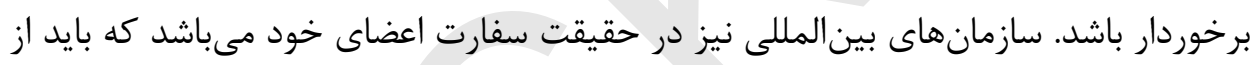

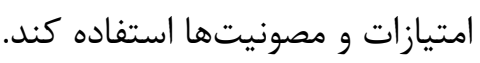

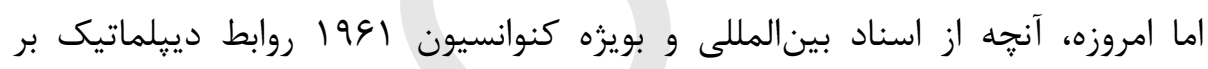

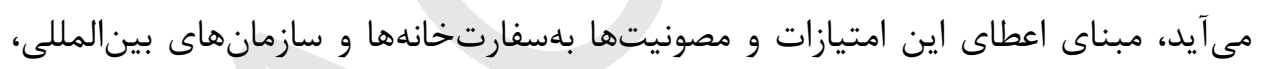

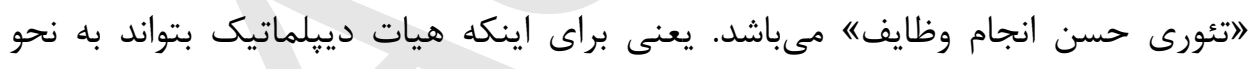

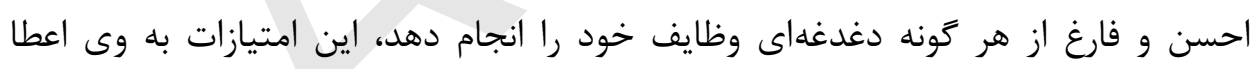

در رابطه با سازمانهاى بينالمللى نيز وضع به همين منوال مىباشد. يعنى براى اينكه

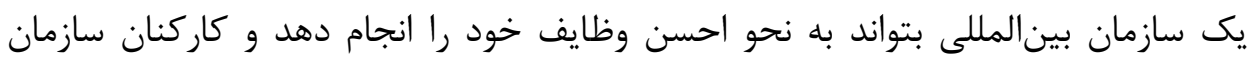

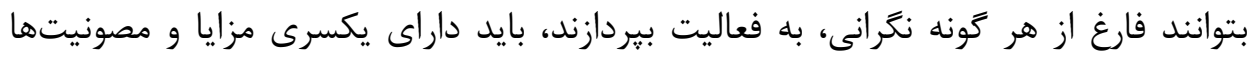

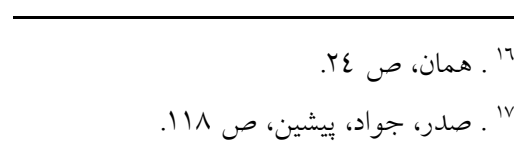


از آنجا كه معمولا نمايندكى سازمانها در دول مقر بهصورت دائمى است وضع آنان با

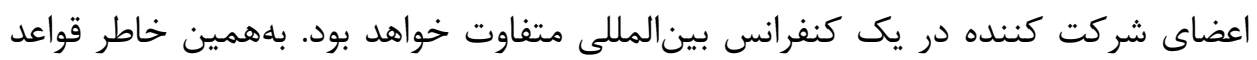
مربوط بهاين موضوع بسيار جديد و در حقيقت با تشكيل جامعه ملل ييدا شده است داست

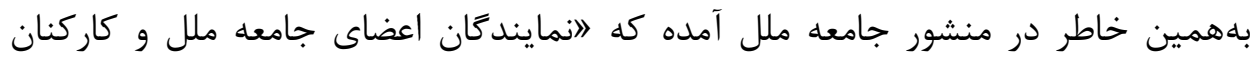

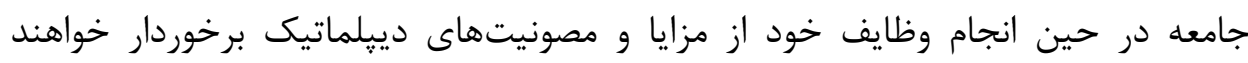

مفهوم جديد مزايا و مصونيتهاى سازمانهاى بينالمللى براى اولين بار در كنفرانس

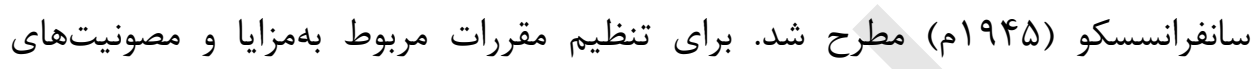

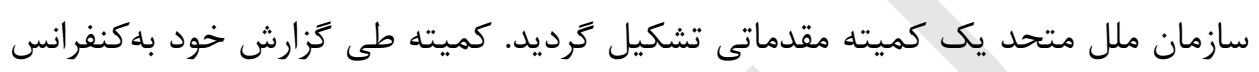

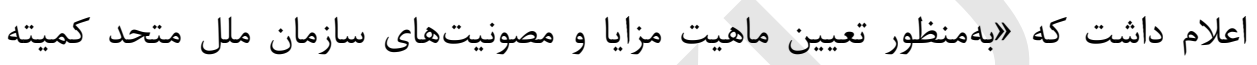

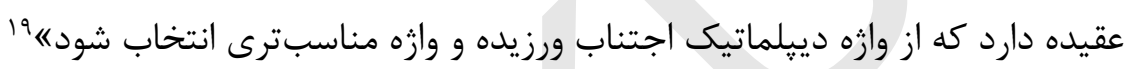

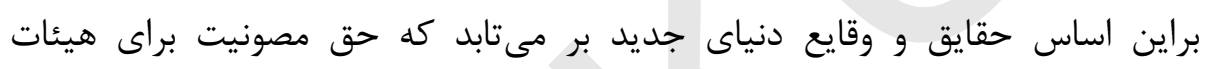

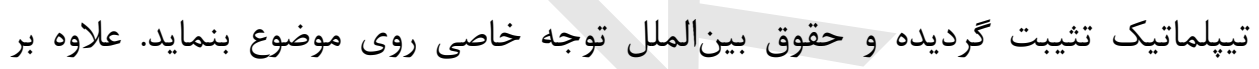

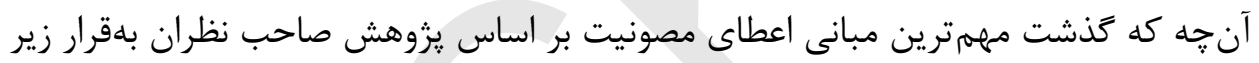
مىباشد:

ا. مصونيتهاى ناشى از حقوق بينالملل عرفى كه مستند بهدكترين معروف بهعمل دولت براى نمايند

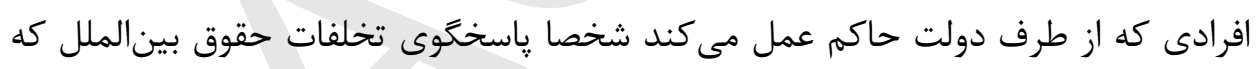

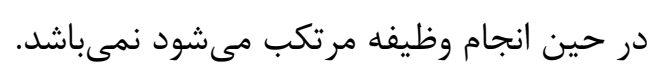

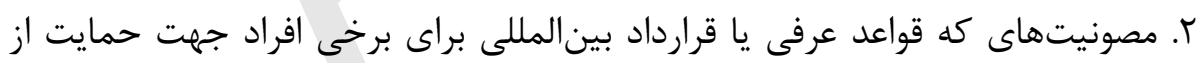

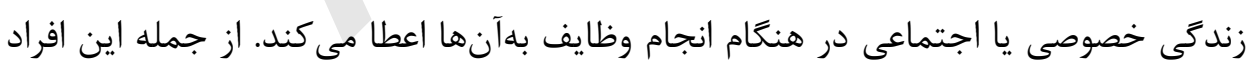

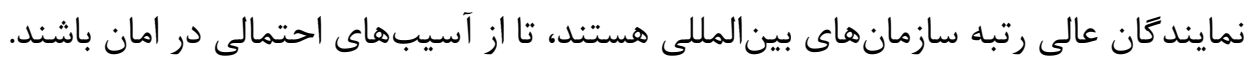


r. مصونيتهاى مقرر در قوانين داخلى كه معمولا بهسران دولتها، اعضاى پارلمان و

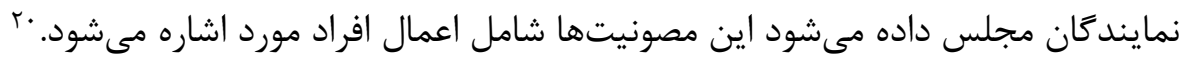

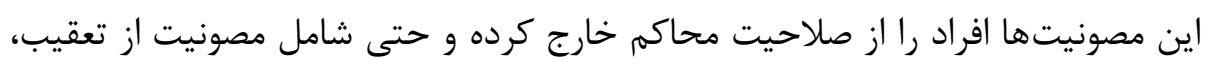

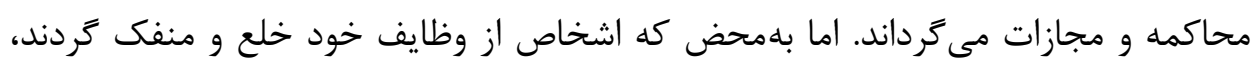

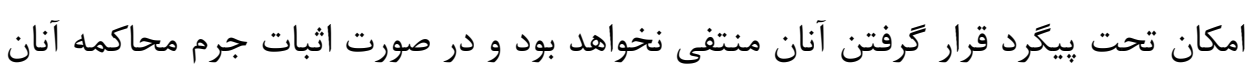

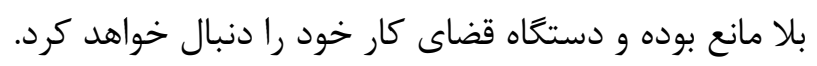

\section{r) جايعاه بيش بينى مصونيت سازمان هاى بين المللى}

اكنون سؤالى كه ممكن است مطرح شود اين است كه مصونيتهاى سازمانهاى بين

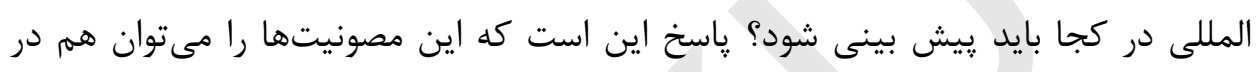

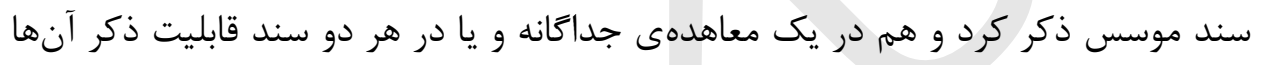

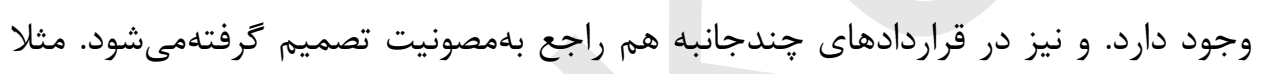

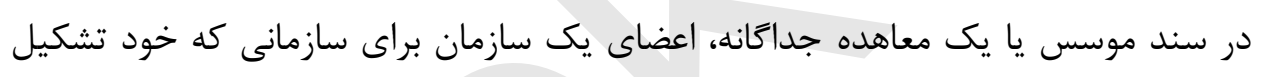

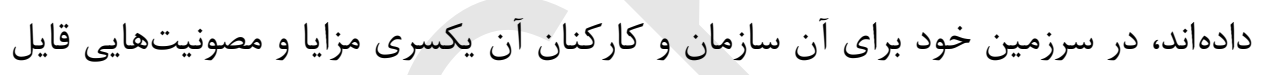

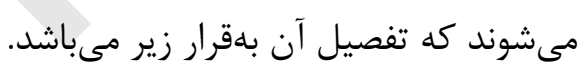

\section{(r-r) سند مؤسس يا مرام نامه سازمان هاى بينالمللى}

بهلطور نمونه، سازمان ملل متحد كه دومين سازمان بزرى بينالمللى بينالدولى است در

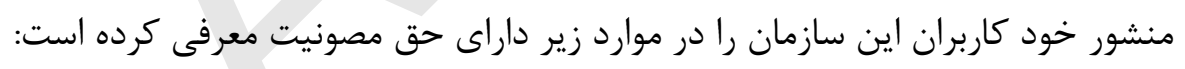

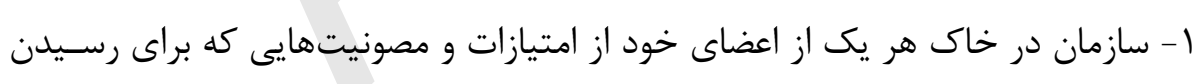

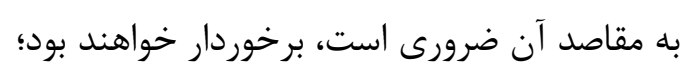

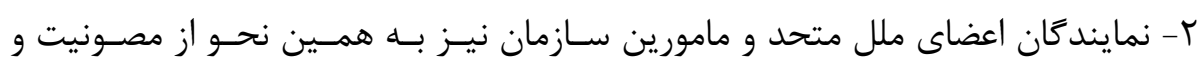

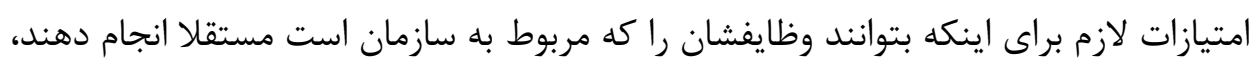

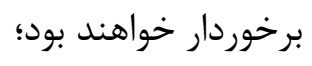


ب- مجمع عمومى مى تواند براى تعيـين جزئيـات اجـــاى بنــدهاى اول و دوم ايـن مـاده،

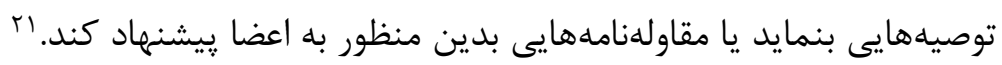

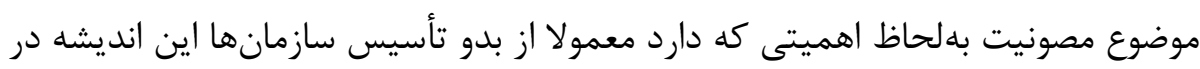
ذهن مؤسسان نقش مى بندد كه در سند تأسيس سازمان اين موضوع را ريش بيش بينى نمايند.

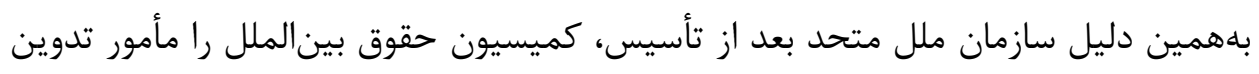

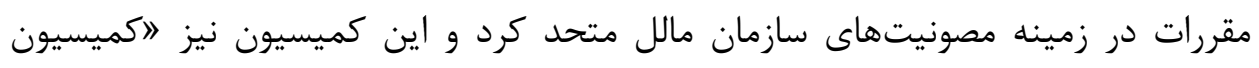

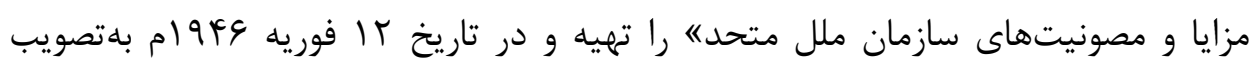
مجمع عمومى رساند. شتاب و اشتهاى سازمانهاى بينالمللى در اين زمنيه تا آنجا سرعت كرفته كه علىرغم

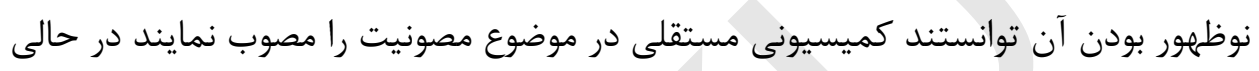

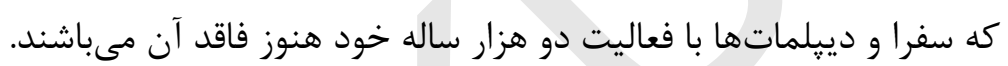

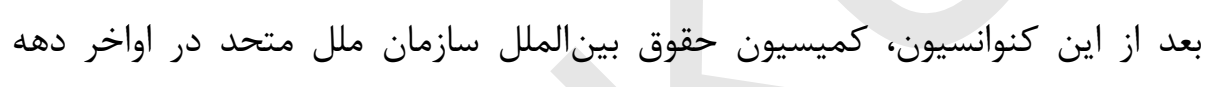

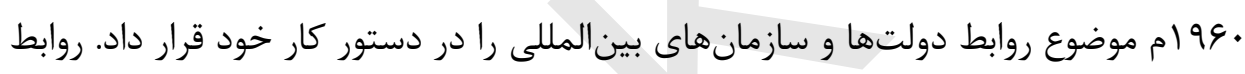

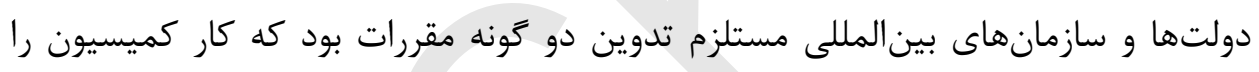

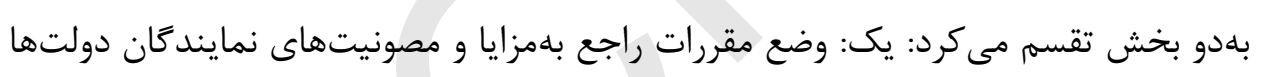

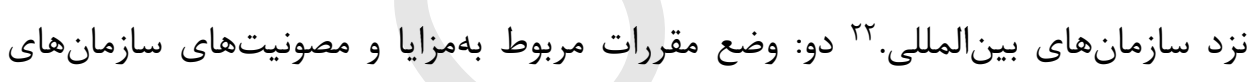

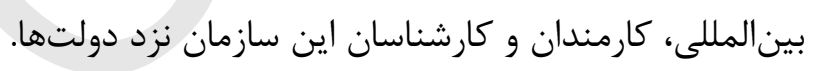

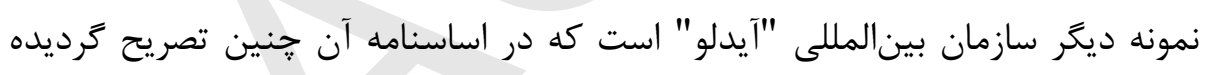
است:

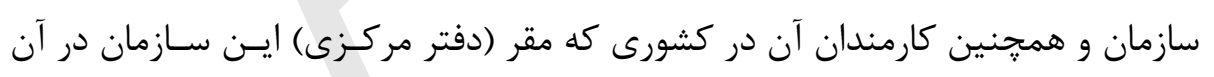

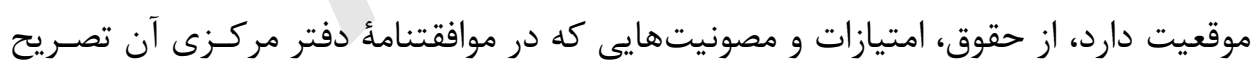

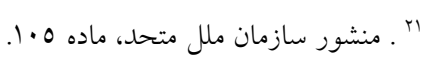

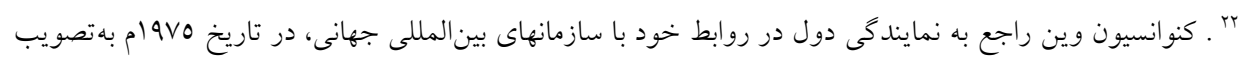

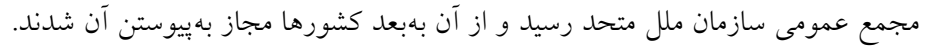


كرديده اند، برخوردار مىباشند. كشورهاى ديكر مى توانند حقوق، امتيازات و مصـئونيتهـاى

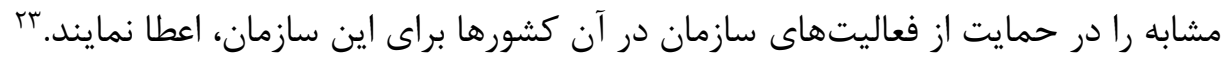

\section{r-Y معاهده فى مابين سازمان هاى بين المللى و دولت مقر}

كاهى نيز سازمان با دولتى كه مقر سازمان در آن قرار دارد، اقدام به انعقاد معاهده

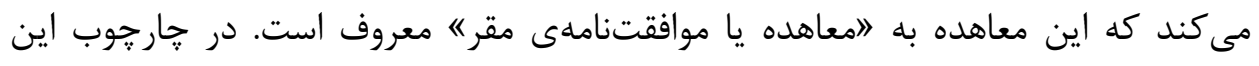

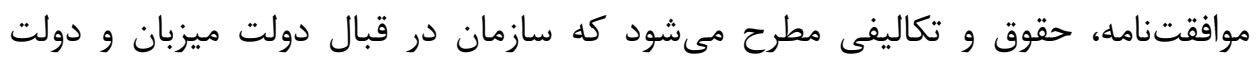

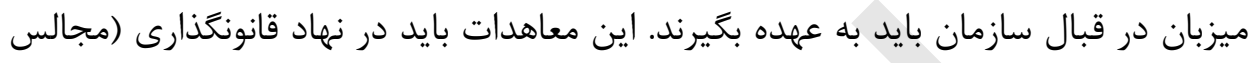

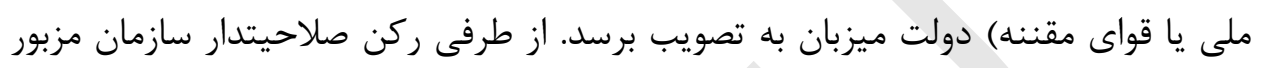

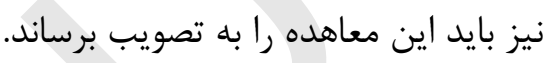

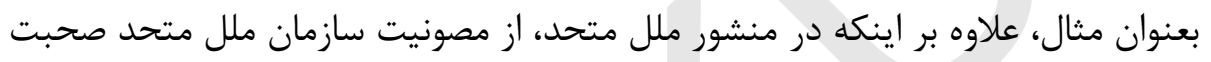

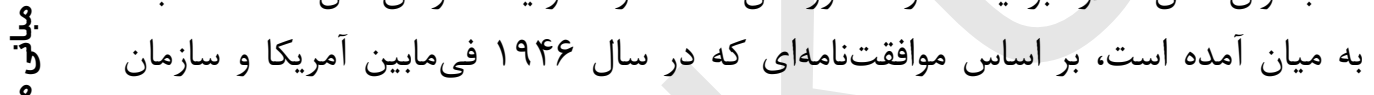

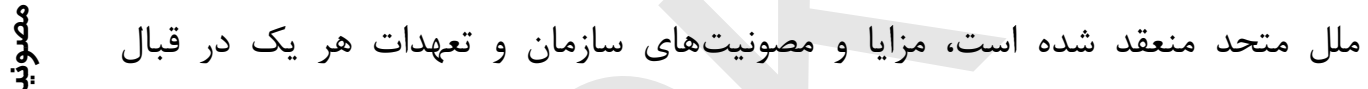

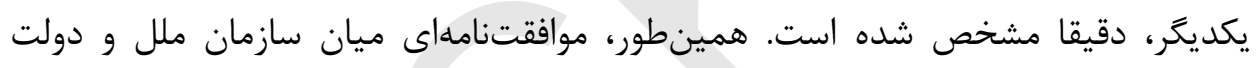

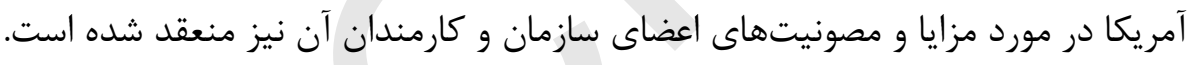

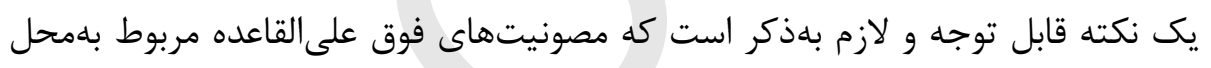

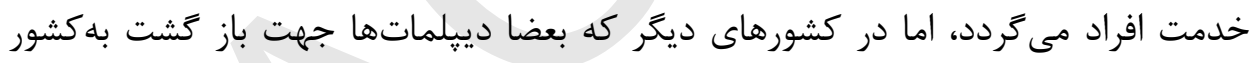

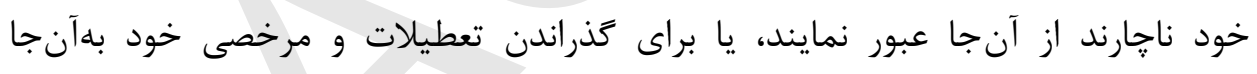
مسافرت مىنمايند نمى

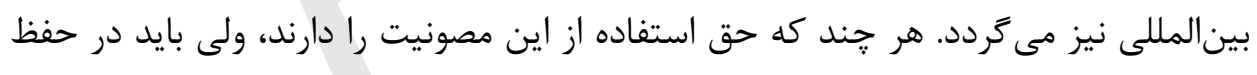

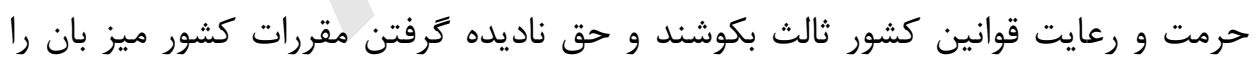
نخواهند داشت. حتومت رعايت

"rا. اساسنامه سازمان بين المللى انكشاف حقوق (IDLO)، ماده لـ مصوب 0 فبرورى 19M1، افغانستان، جريده رسمى

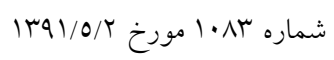

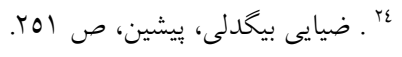




\section{ץ-ץ - معاهده جند جانبه ميان كشور رها و سازمان هاى بينالملل}

اصول حاكم بر مصونيت جون داراى اهميت فوقالعاده مهم است، گاهى بيش بينى آن

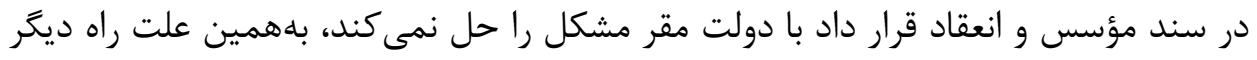

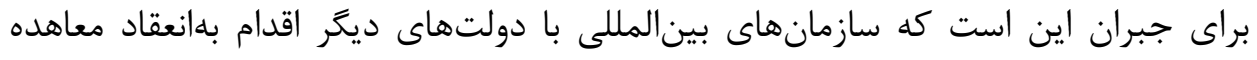

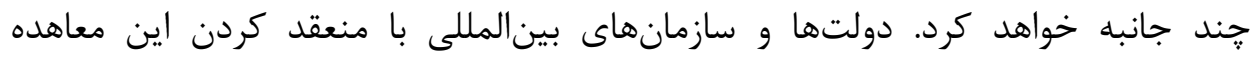

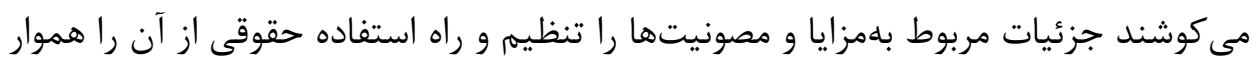
سازند.

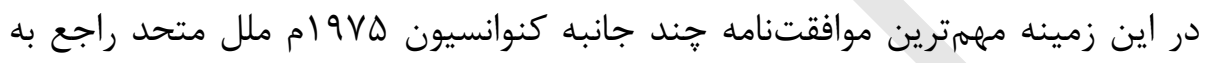

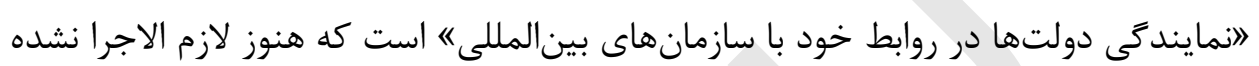

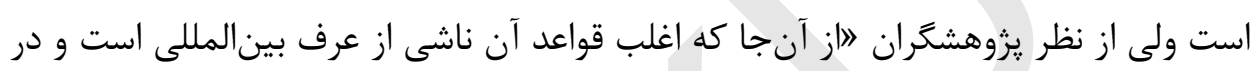

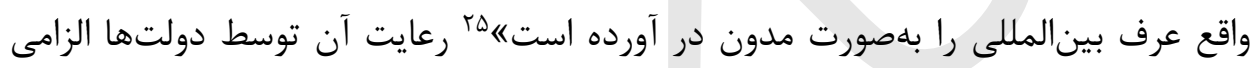
شناخته شده است.

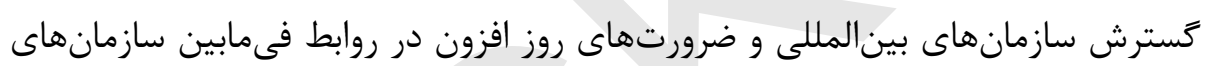

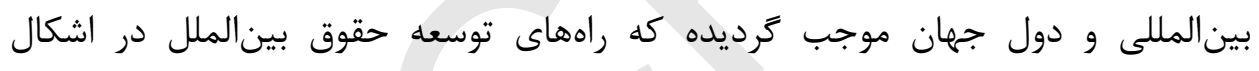

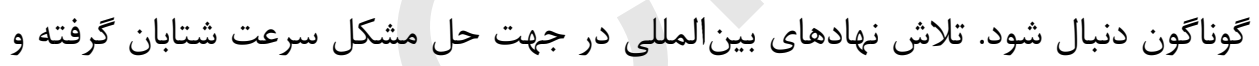

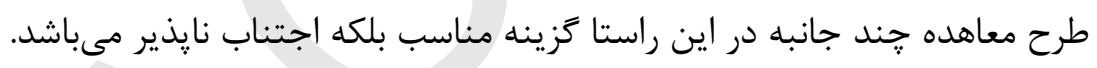

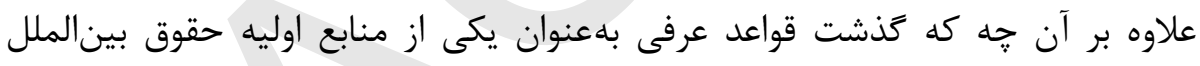

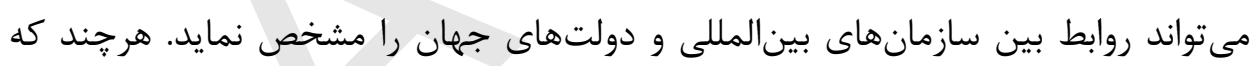

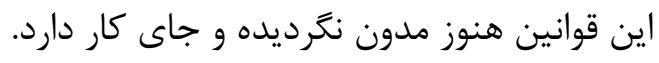

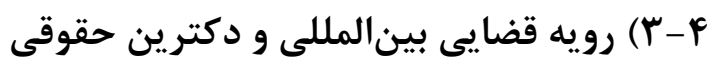

آراء قضايى محاكم (مخصوصا ديوانهاى بينالمللى) نيز قابليت اين را دارد كه بتواند حق

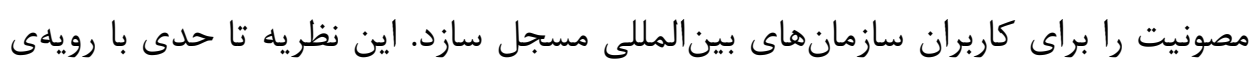
قضايى بينالمللى منطبق است. اين نظريه ناشى از يك نظر مشورتى مى مشود كه ديت ديوان 
بينالمللى دادَسترى در سال و\&9 ام تحت عنوان 》خسارات وارده به سازمان ملل متحد"

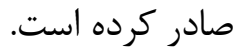

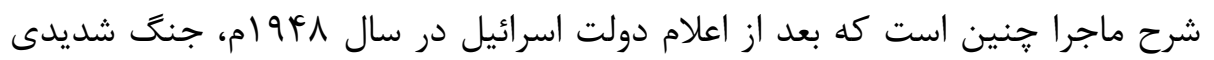

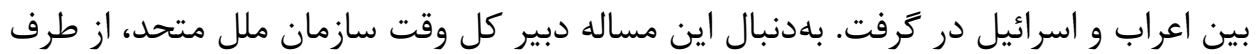

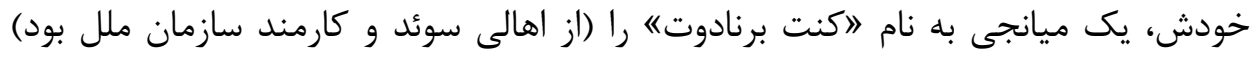
براى خاتمه دادن به اين وضعيت به سرزمينهاى اشغالى فرستاد. اين فرد در اسرائيل كشته

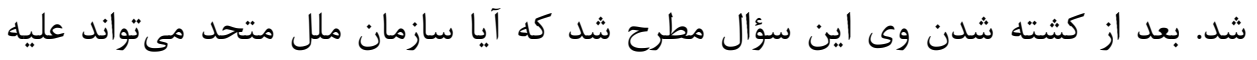

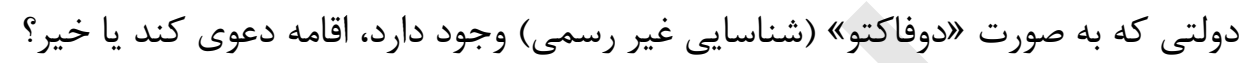

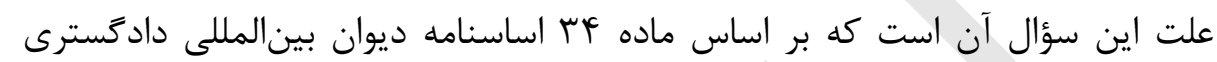

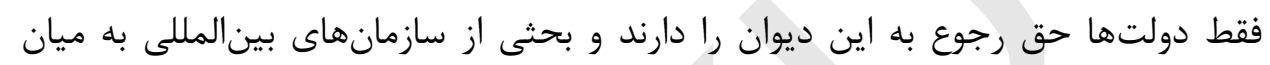

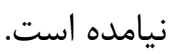
در اين قضيه، ديوان اعلام كرد كه ما براى تشخيص سازمانها نبايد به ماهيت افرادى كه

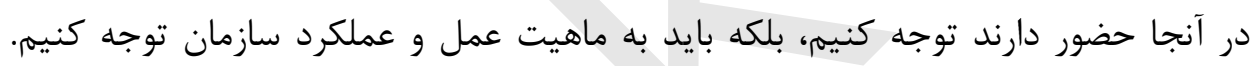

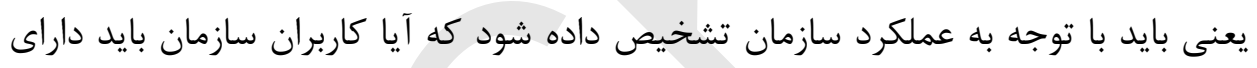
مصونيت باشند يا خير؟ نظر مشورتى ديوان در مورد داشتن حق دفاع سازمان ملل متحد از حقوق كاركنان خود

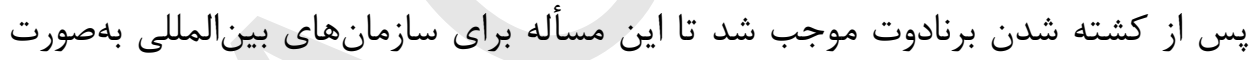
يك قاعده حقوقى در آيد و مورد عمل واقع شود.

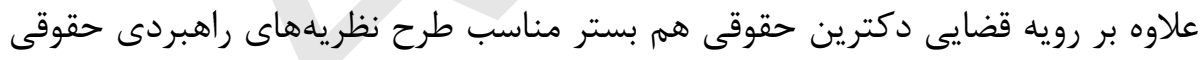

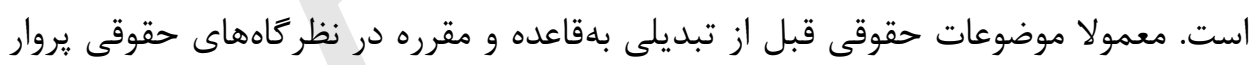

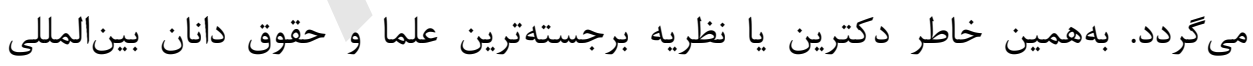

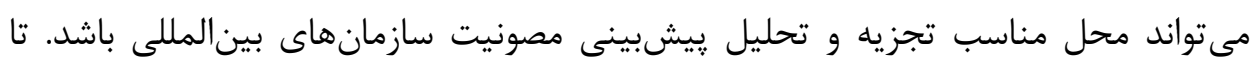

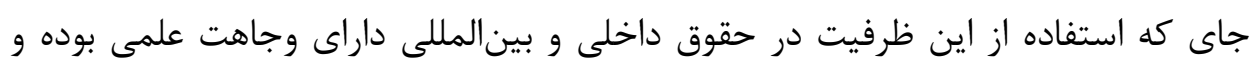
معتبر مىباشد.

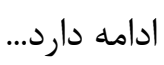




\section{مرف او لهه فقهب اهما هو كب هد بدلون ونهبه}

ابو صهيب

مقدمه - - - مقد

عرف هغه فقهب مصدر دى تب د احكامو بِه حكم او بدلون كي يوره ونله لري، تولو فقهاؤ ته

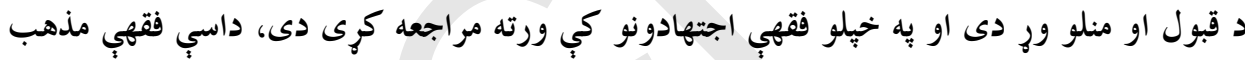

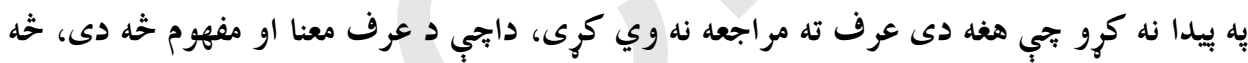

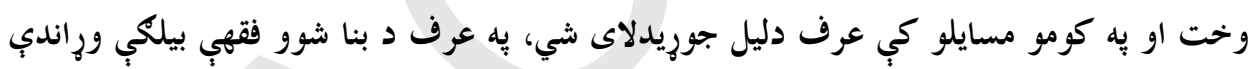

$$
\text { كيوب. }
$$

\section{د عرف لغوي او شرعي معنا:}

د عرف لغوي او اصطلاحي معنا: عرف به لغت كي دود، رسم او رواج ته ته ويل كيبري(') دغه راز

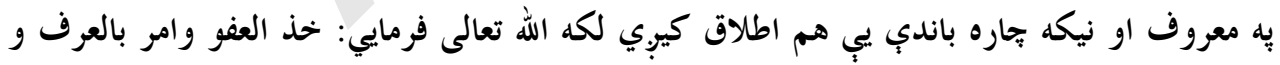

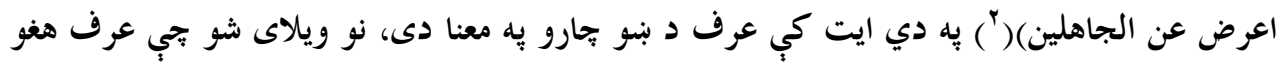

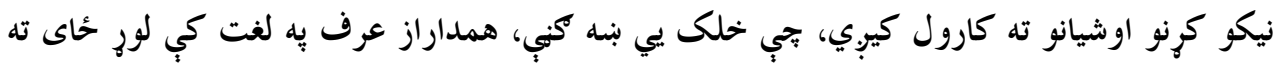

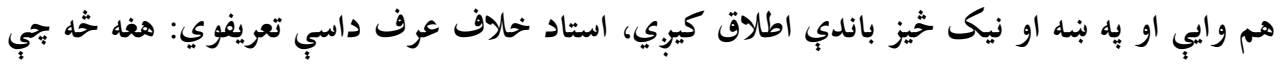

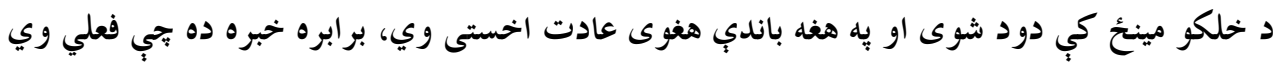

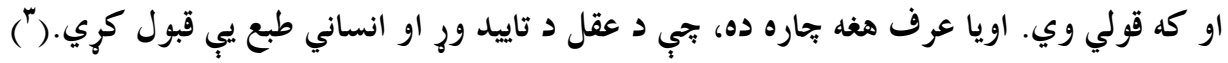


پس بِه عرف كي د جمهورو خلكو مشتركى عادات او يا د هغو ترمينح بِه غالبه تو كهه د هغو

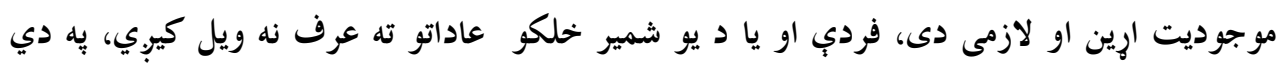

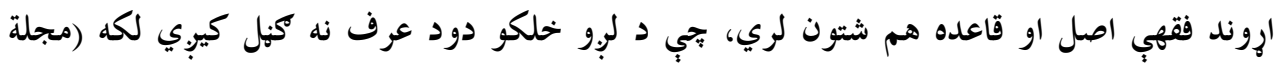

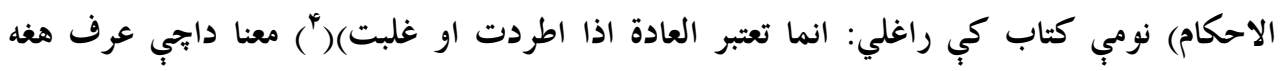

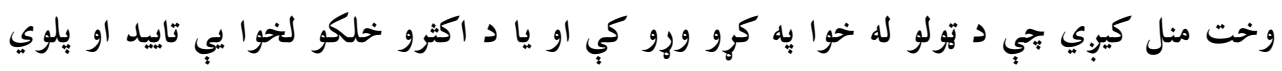

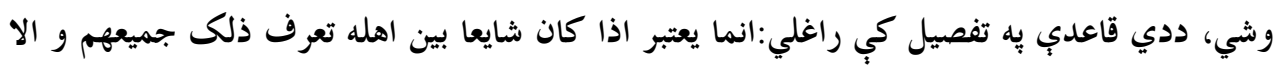

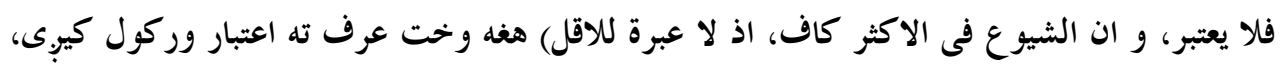

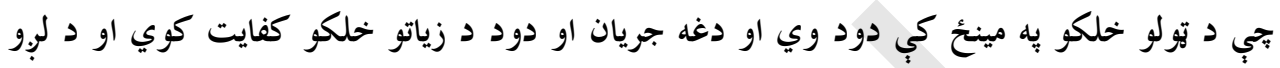

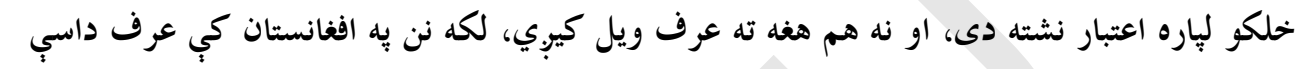

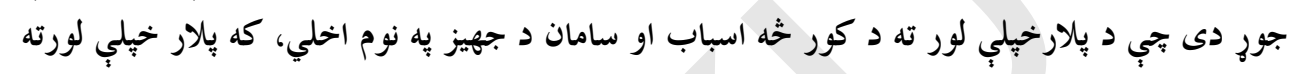

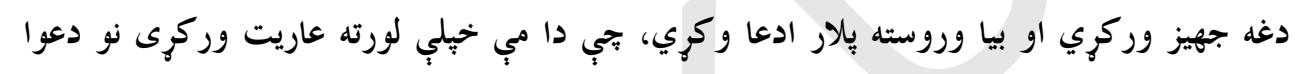

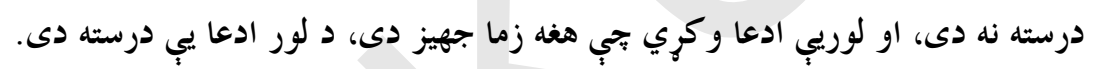

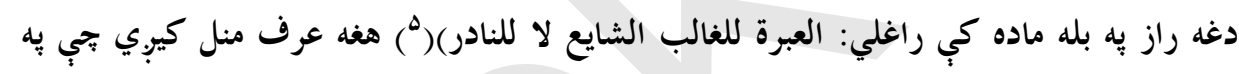

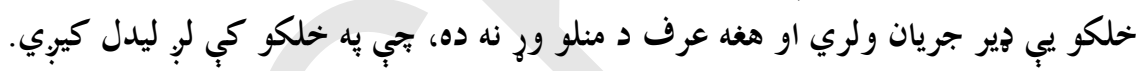

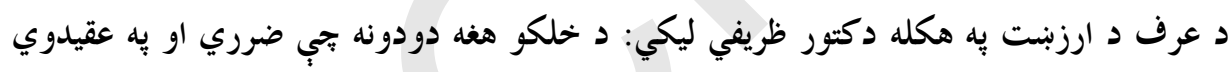

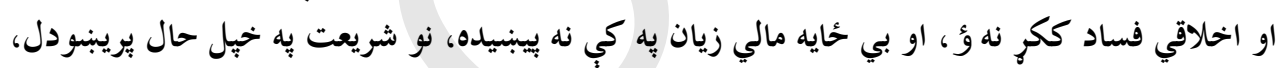

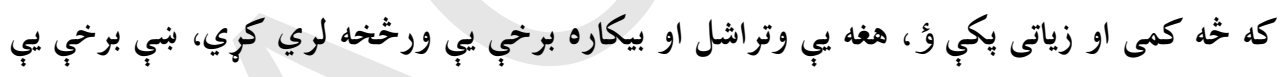

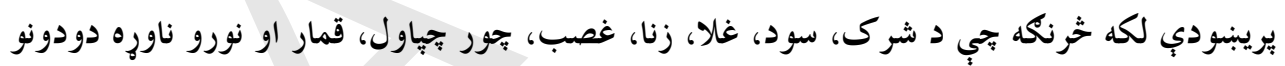

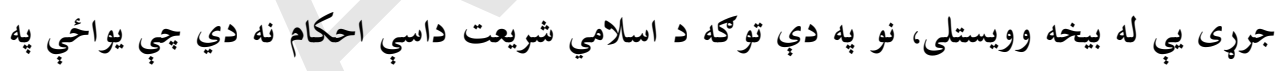

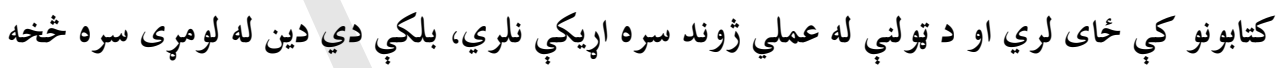

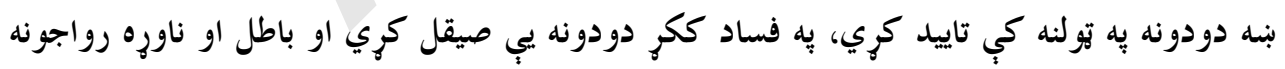

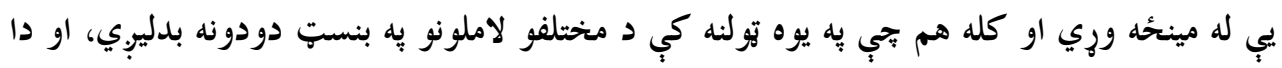

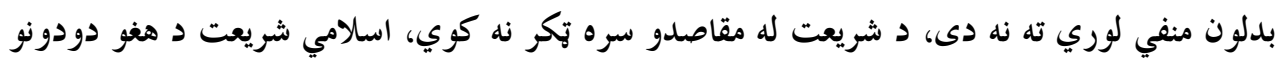

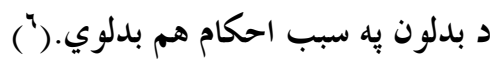

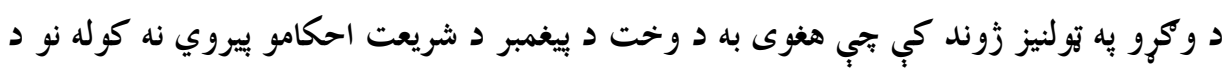

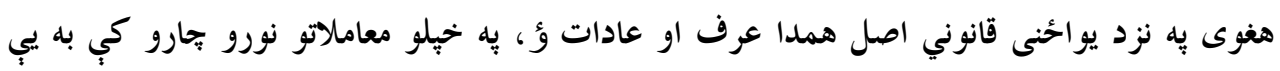

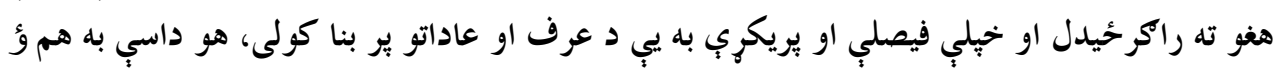


جي حُيني عرف او عادات د دين او شريعت خلاف ؤ او حُينب به دين سره موافق ؤ، زمونب. بِ هيواد

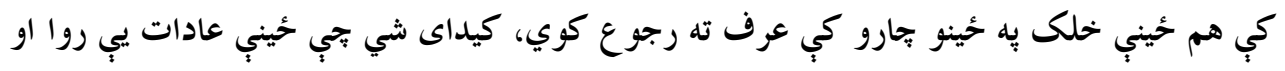

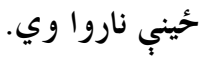

به اوسني وخت كي عرف او دودونه د حقوق بورهانو به نظر د دوضعي قوانينو يو مهم مصدر او

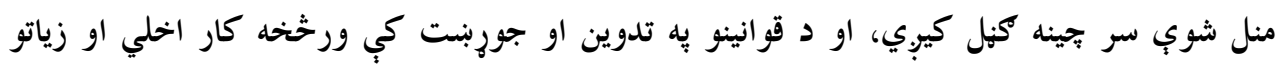

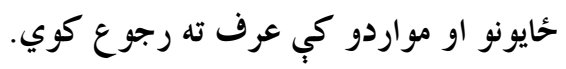

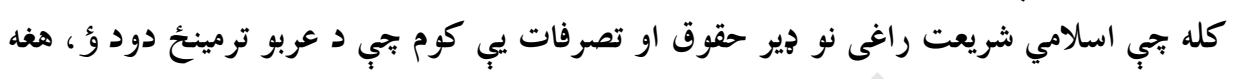

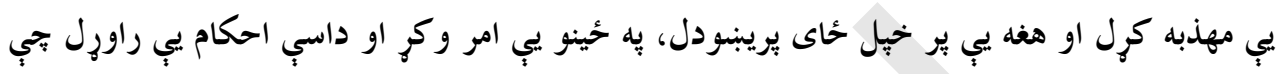

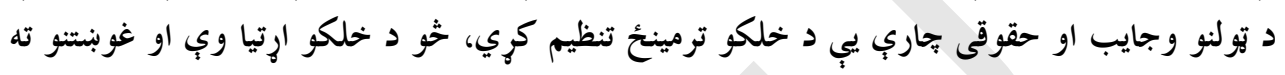

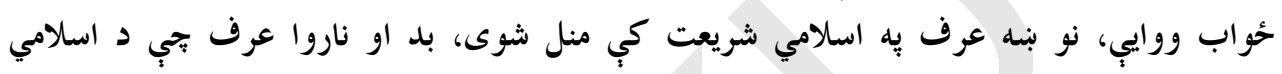

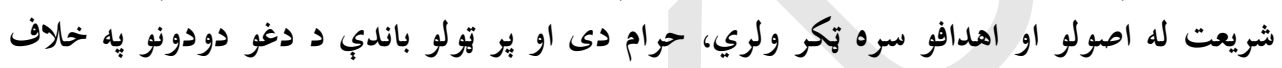

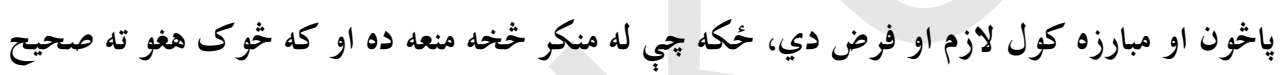

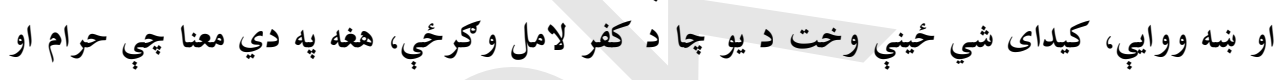

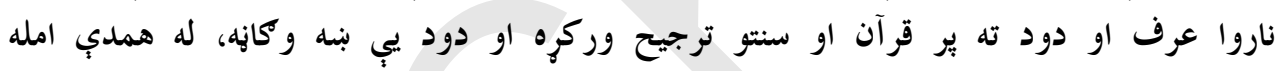

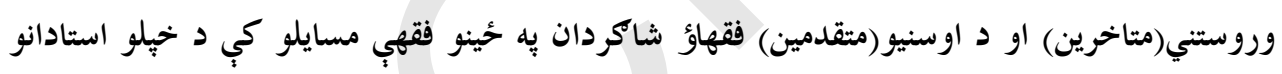

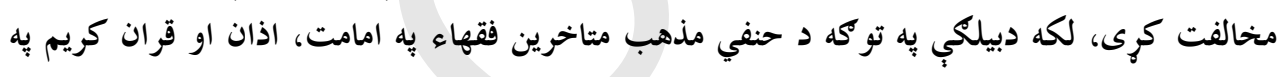

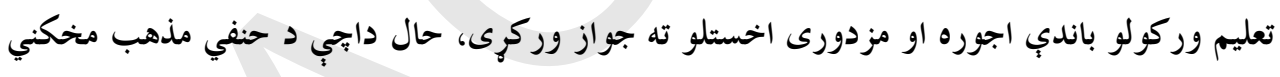

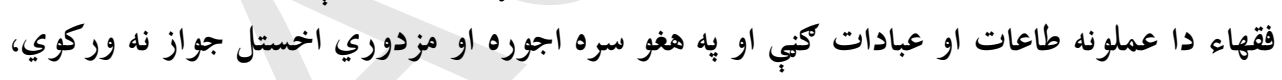

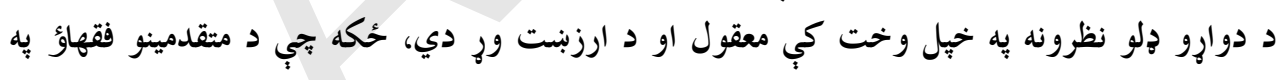

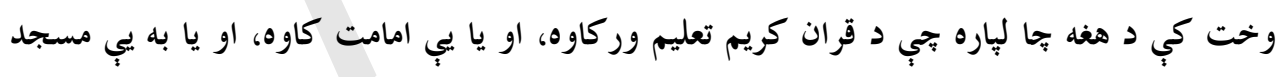

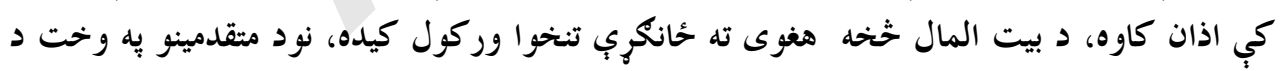

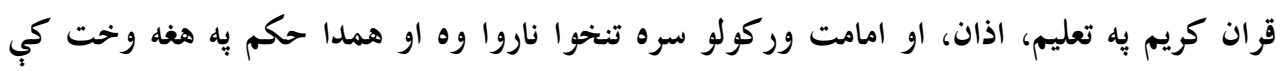

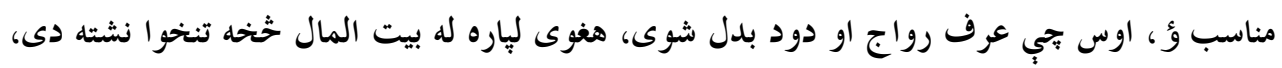

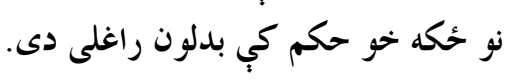

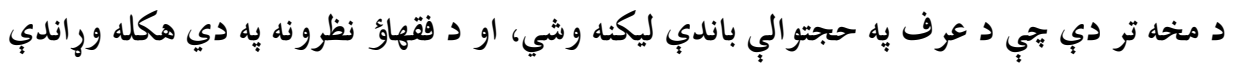

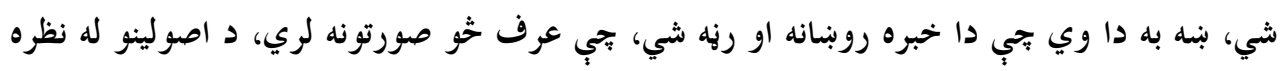


كوم عرف د بحث او خيرنب موضوع تشكيلوي، كه د خلكو عرف او عاداتو ته بنه خير شو او هغه د

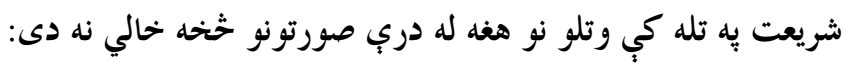

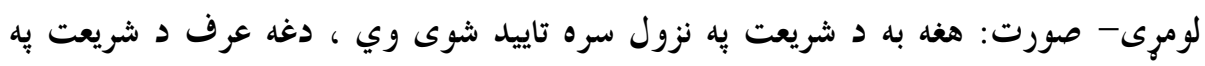

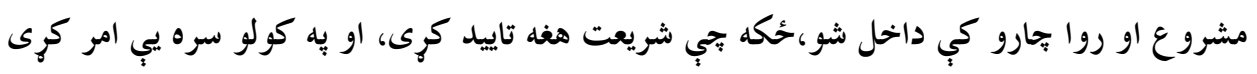

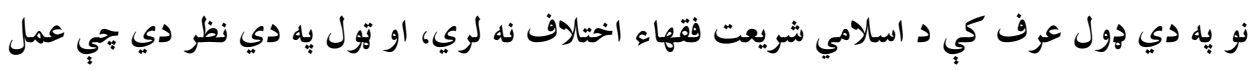

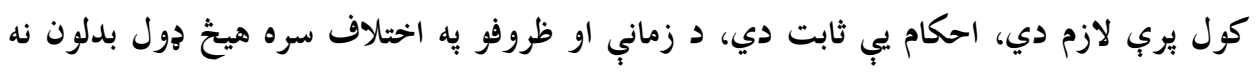

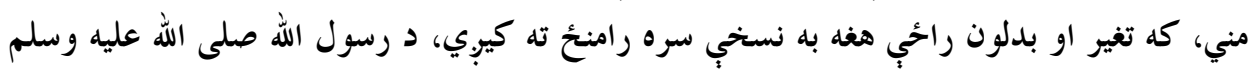

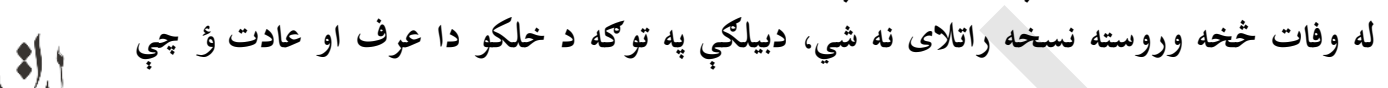

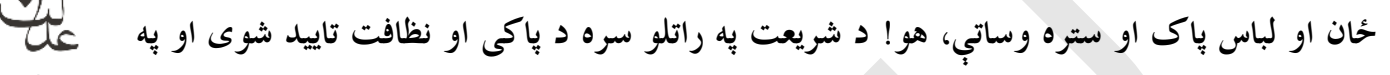

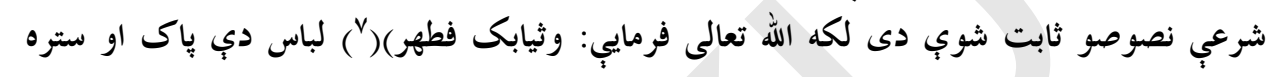

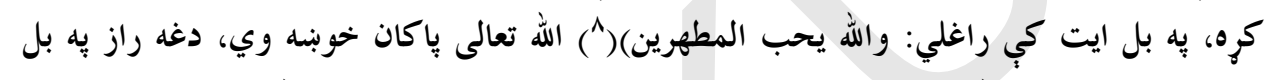

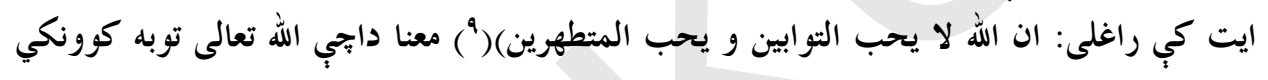

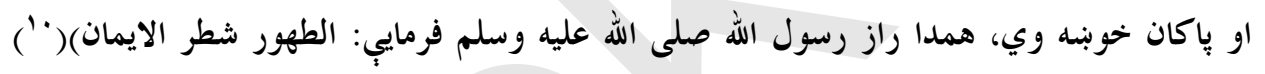

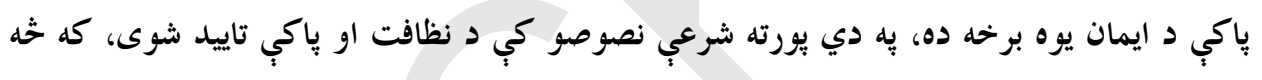

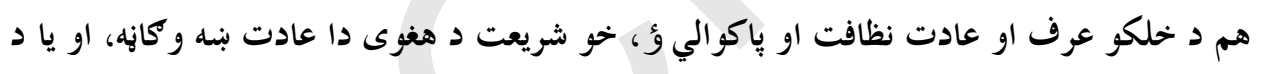

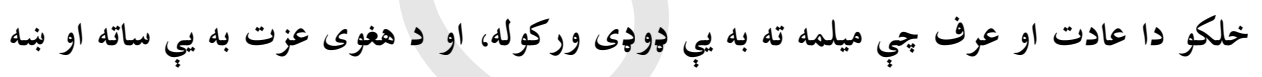

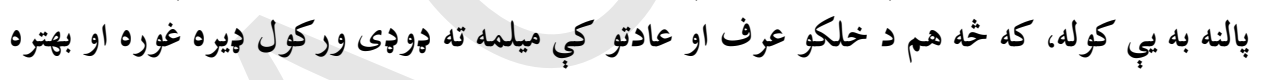

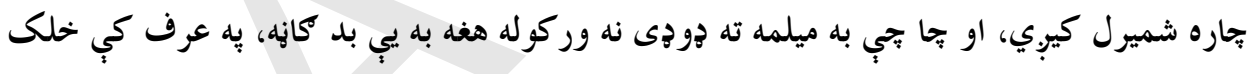

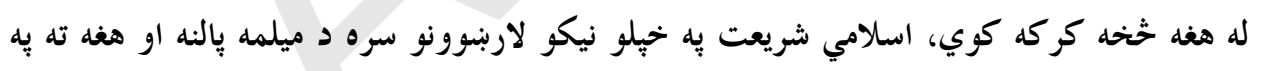

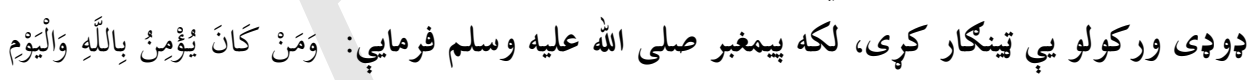

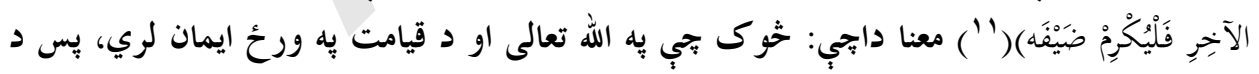

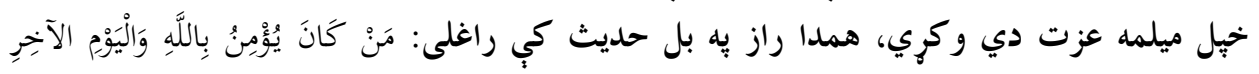

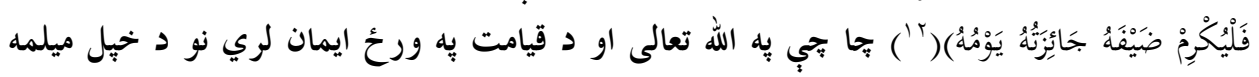

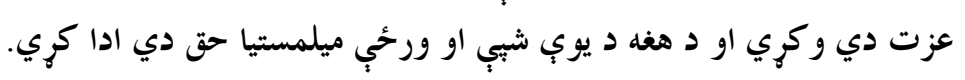

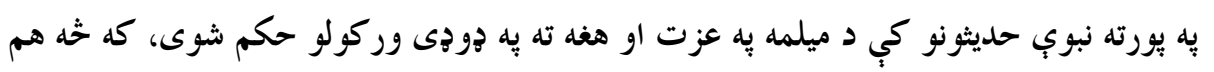

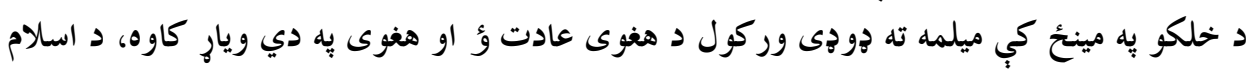

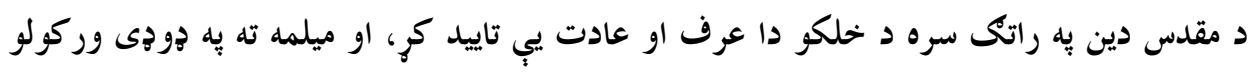




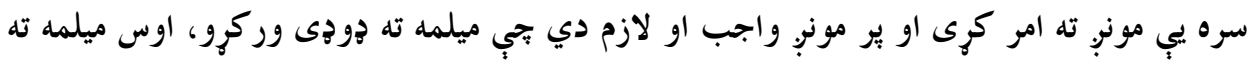

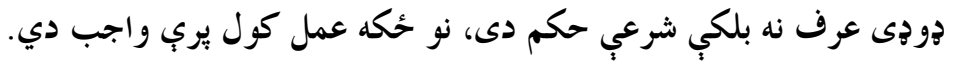

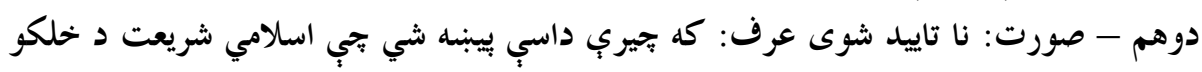

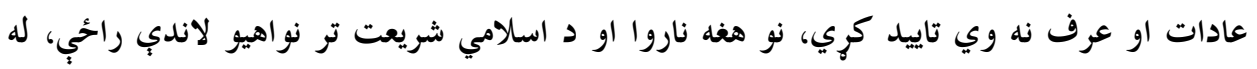

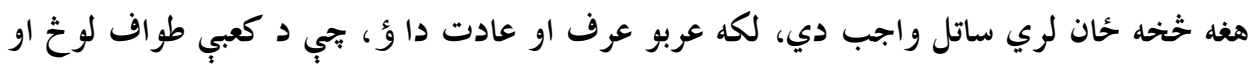

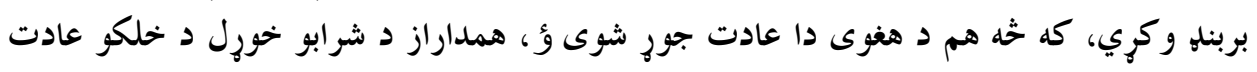

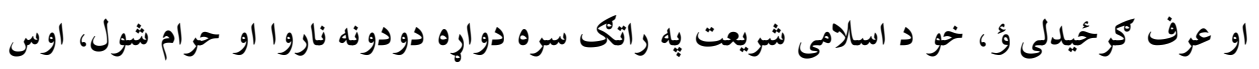

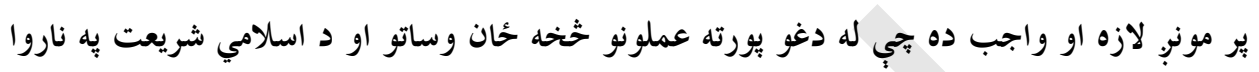

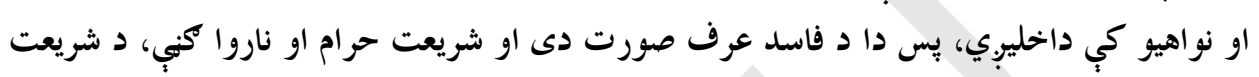

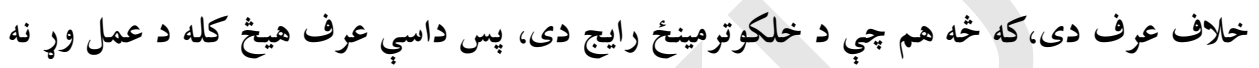

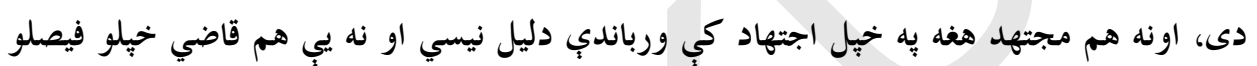
كي رعايت كوي.

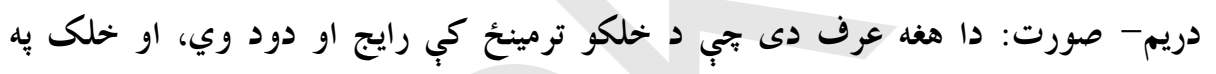

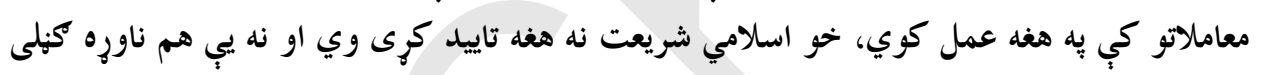

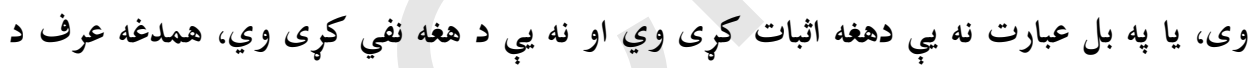

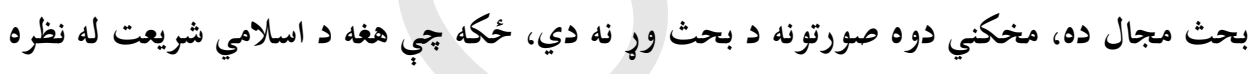
تاييد او يا نا تاييد شوي دي.

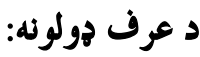

عرف بيلابيل جولونه لري، تجي حُينب يب به فقهب مسايلو كي د اعتبار وري دي او فقهاء ورته

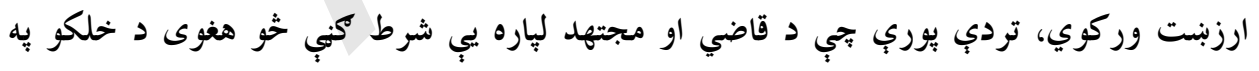

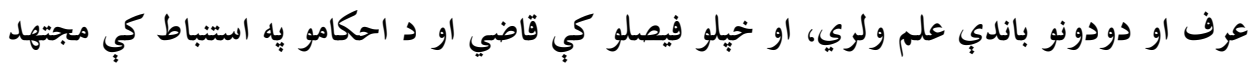

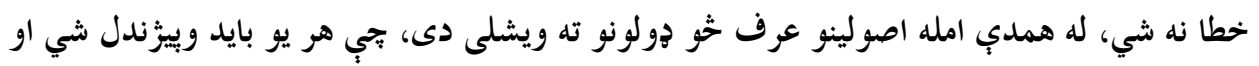

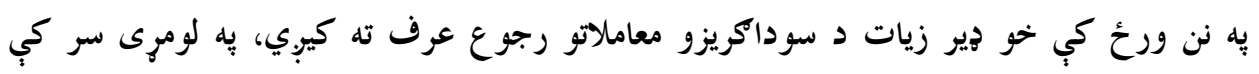

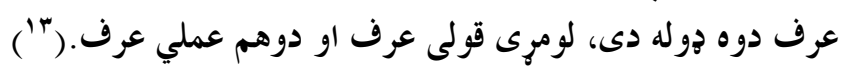

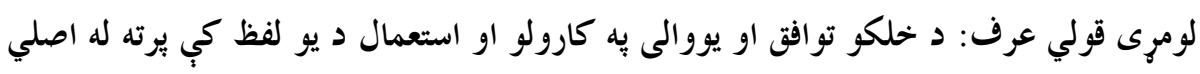

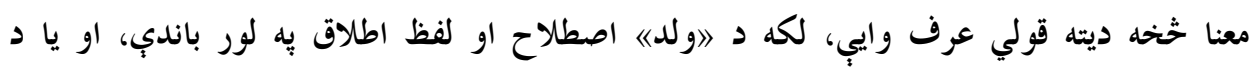




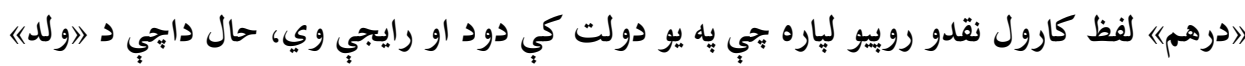

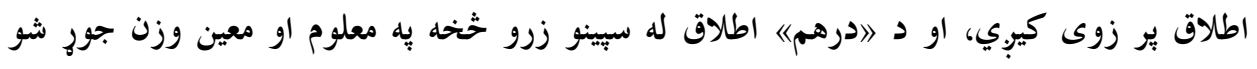

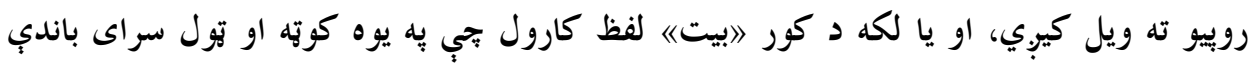
اطلاق كيبري.

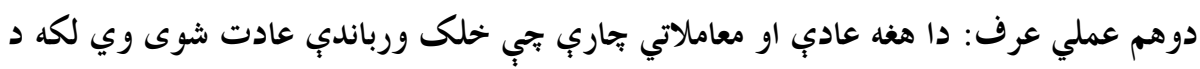

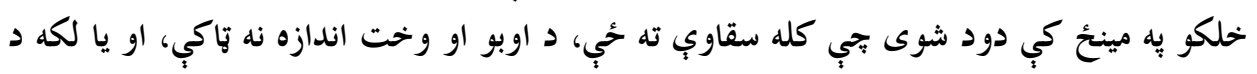

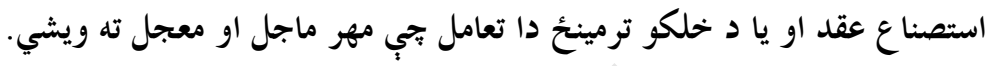

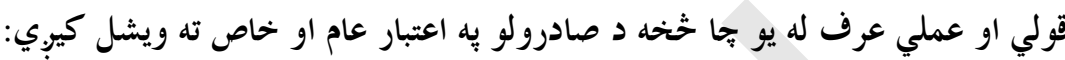

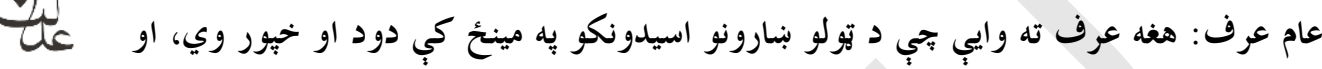

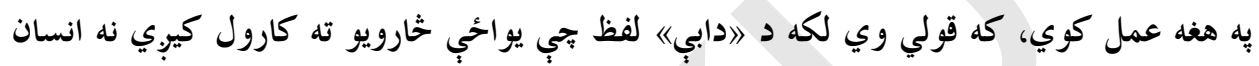

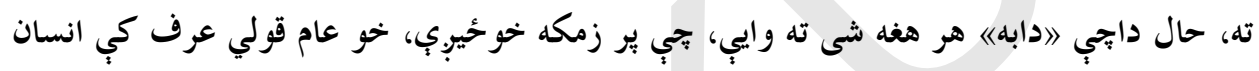

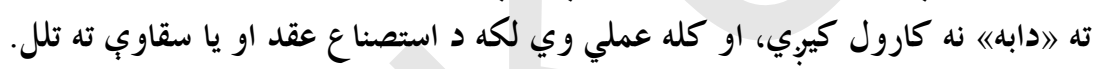

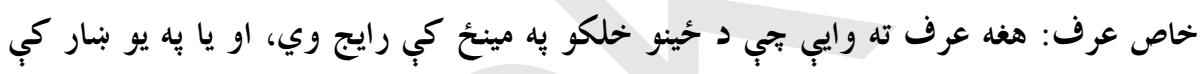

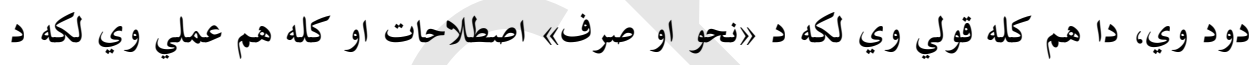
لورانو لِاره جهيزيه وركول.

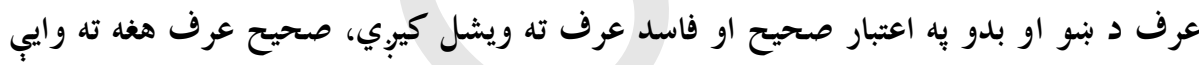

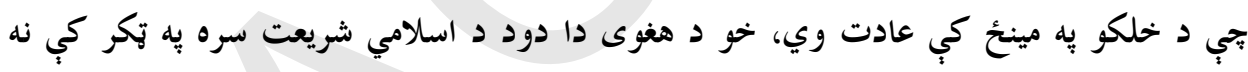

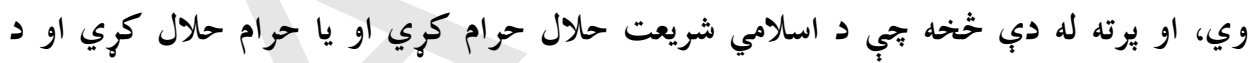

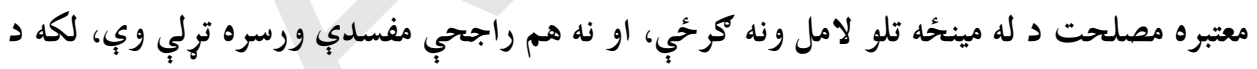

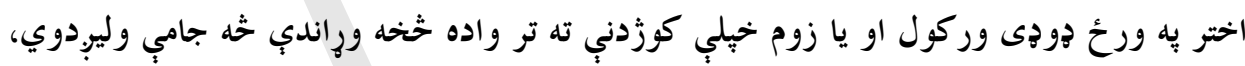
pr

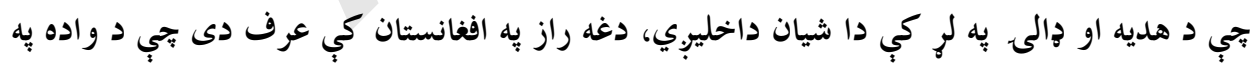

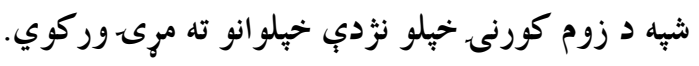

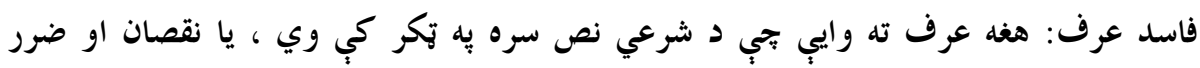

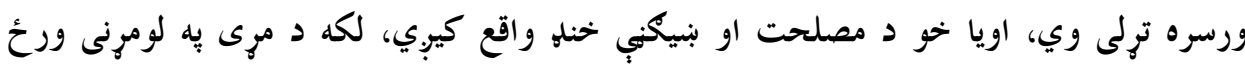

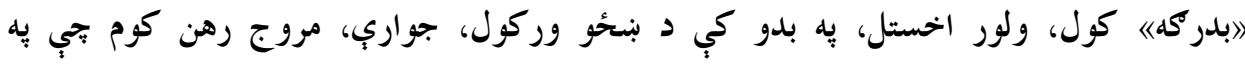

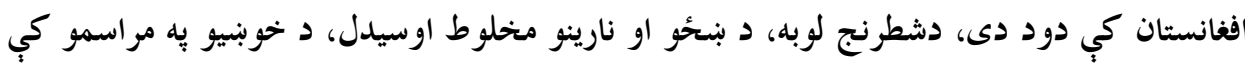

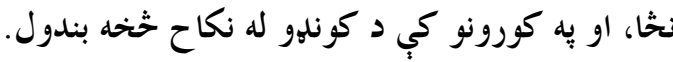


يه عرف باندي دليل نيول او به فقهب مسايلو كي هغه ته راكرخيدل، د فقهاؤ ترمينح اختلاف

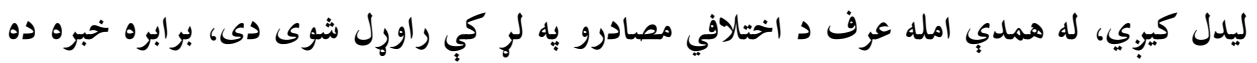

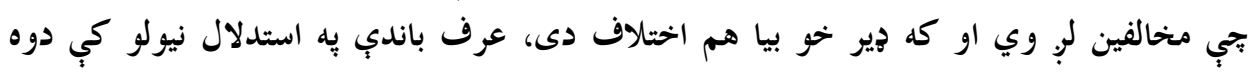

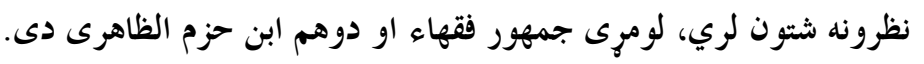

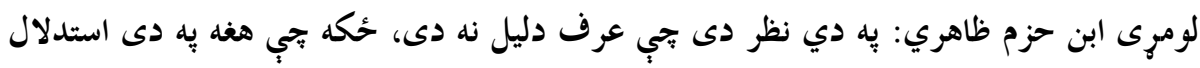

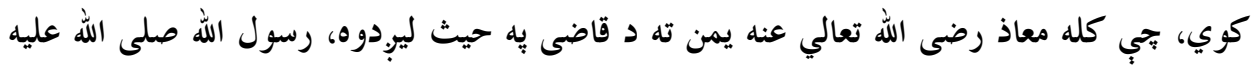

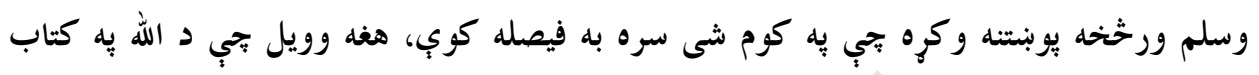

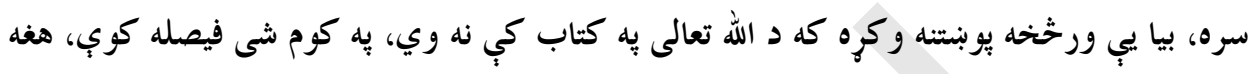

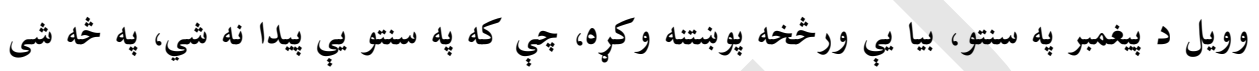

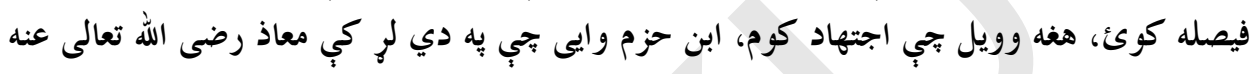

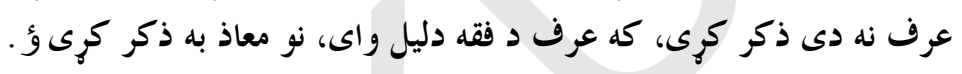

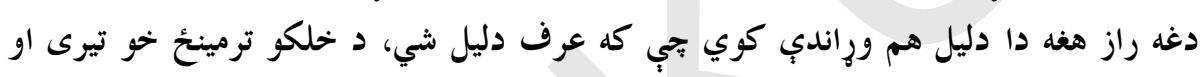
ظلم هم دود او عرف كرحيدلاى، نو هغه دي هم روا شي.

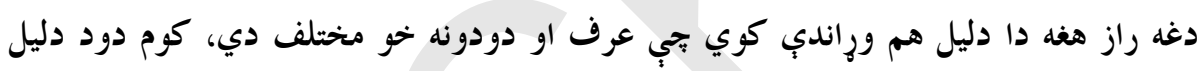
وكرحول شي، دلته خو اختلاف رامينح ته كيبري.

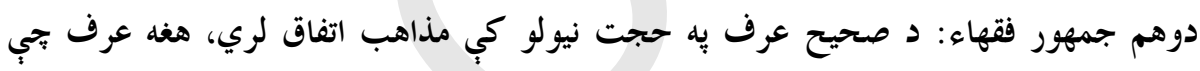

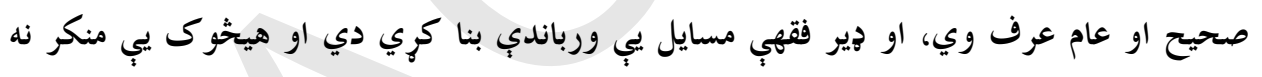
دي. (")

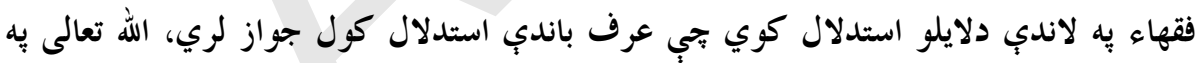

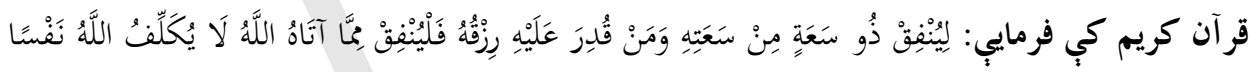

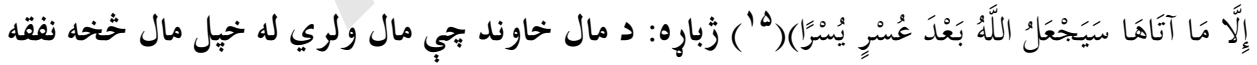

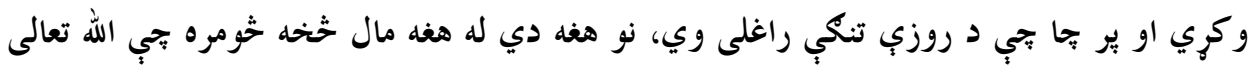

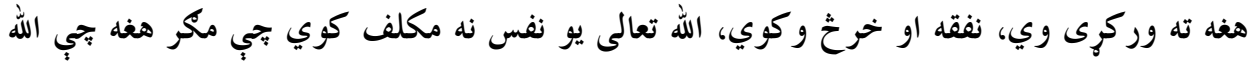

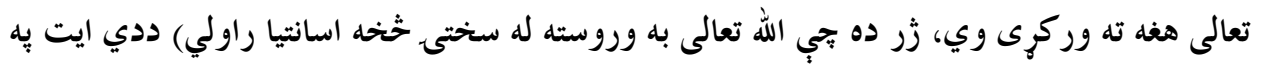

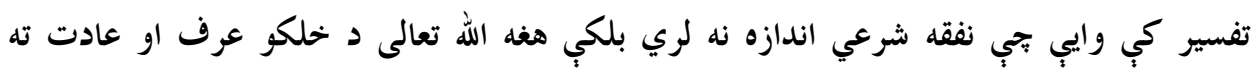

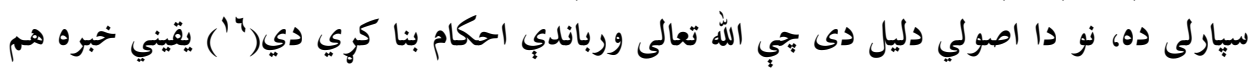

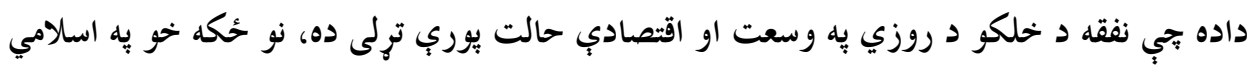


نصونصو كي د نفقي اندازه نه دى تاكل شوى او دا خبره عرف او دودته سبارل شوب ده، له همدي

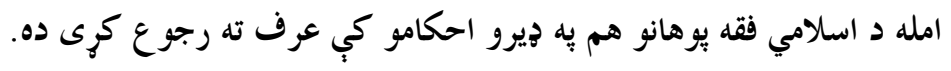

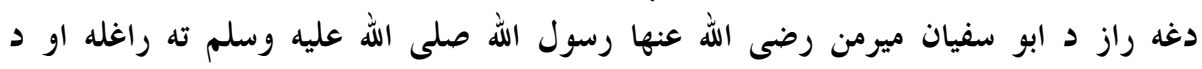

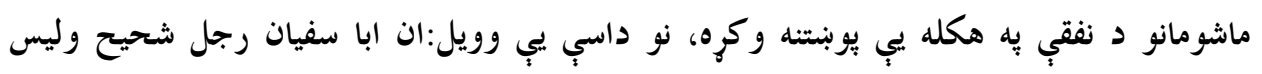

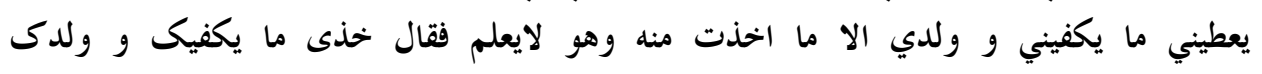

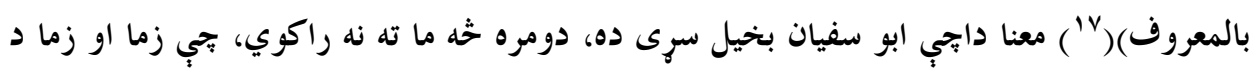

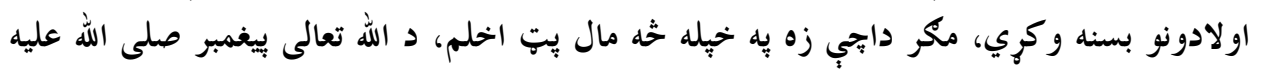

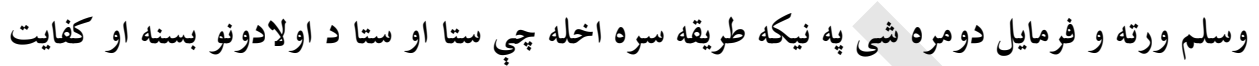

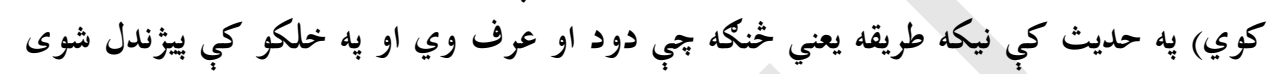

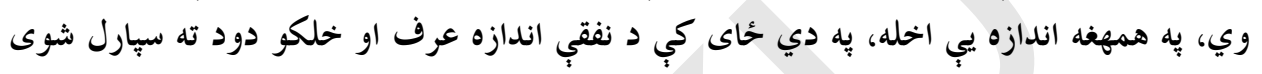

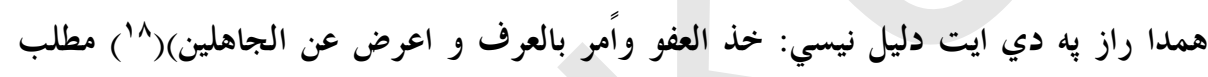

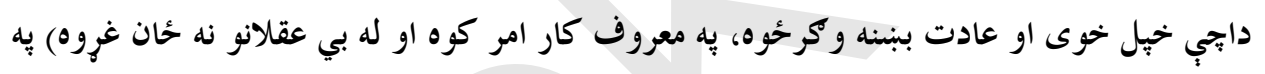

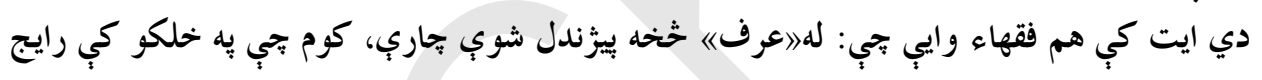

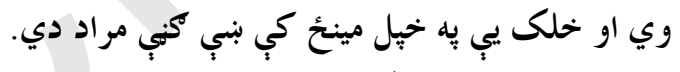

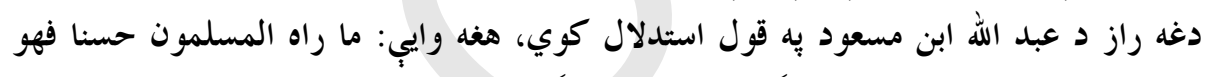

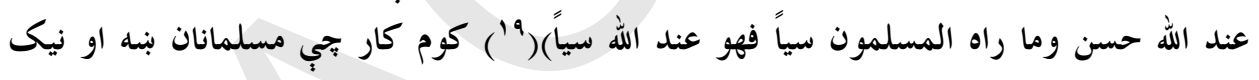

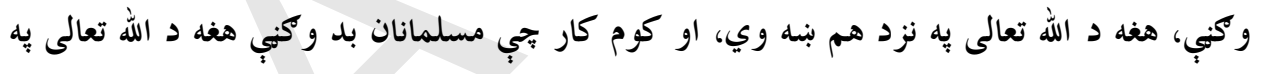

$$
\text { نزد هم بد وي. }
$$

د عرف يُه هكله عقلي دلايل:

ro

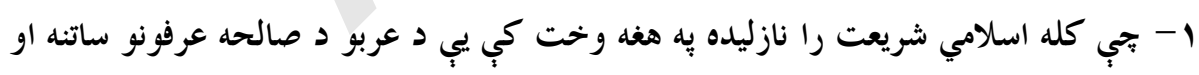

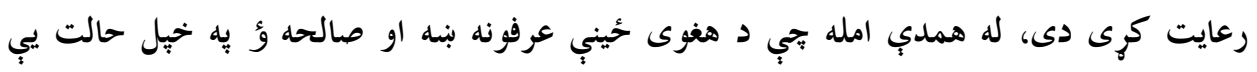

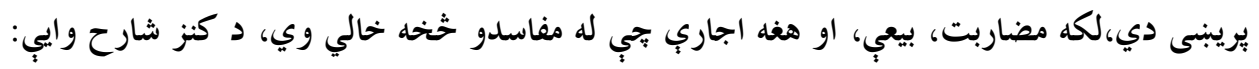

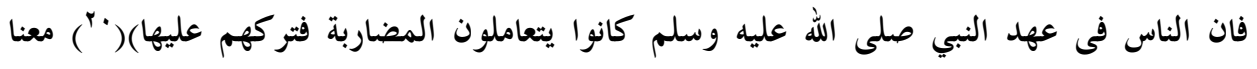

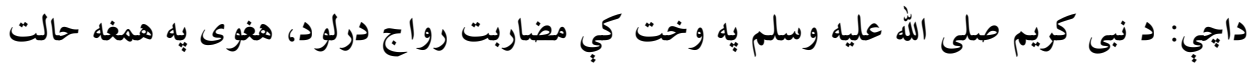

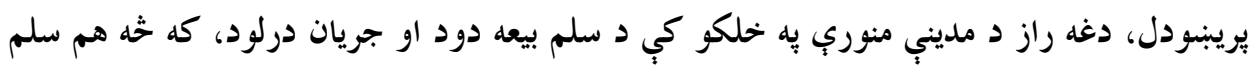

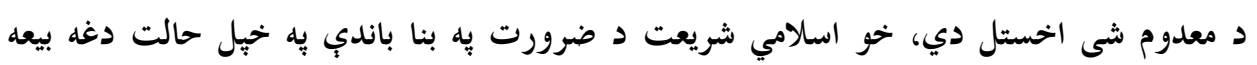




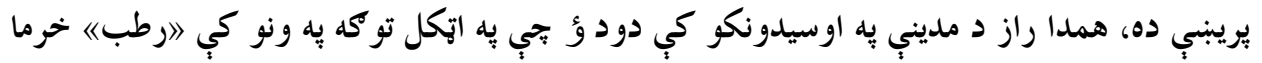

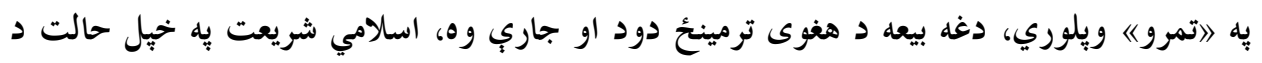

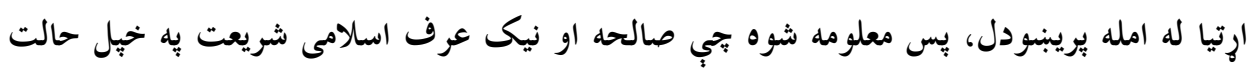

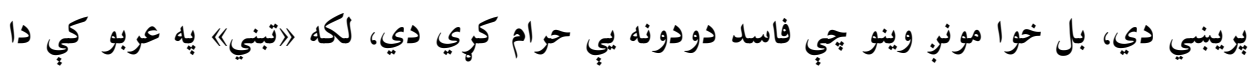

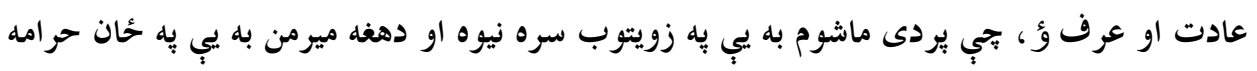

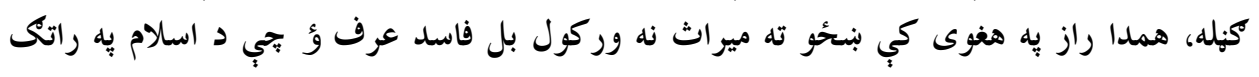

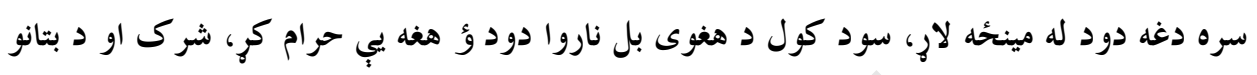
عبادت ناوره دودؤ هغه يبي حرام شو.

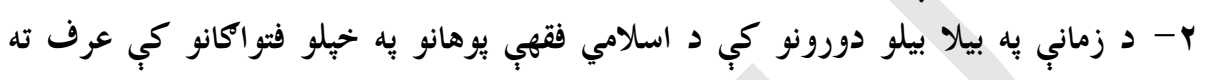

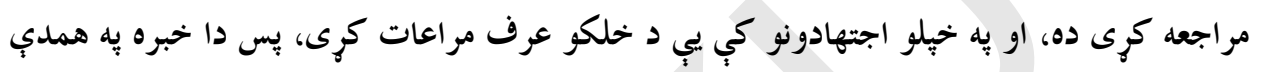

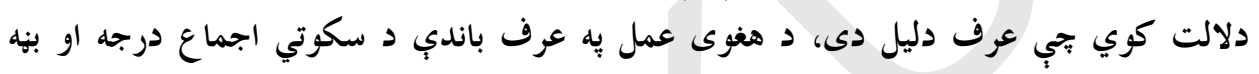

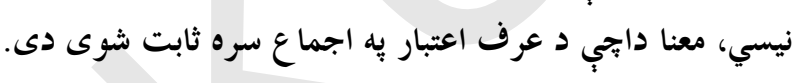

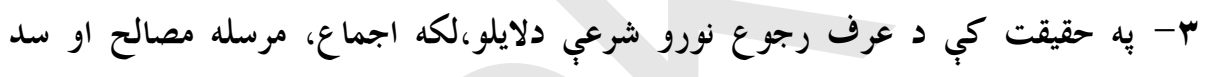
الذرايع ته كيبوي. دغه راز د فقهب مذهبونو د مشهورو فقهاؤ بِه كتابونو كب د هغوى ويناوي او ليكني صراحت

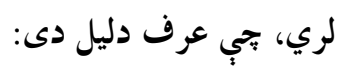

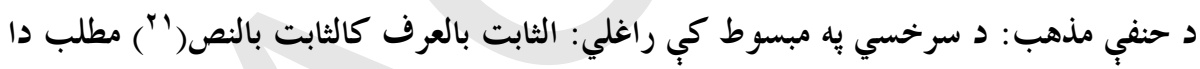

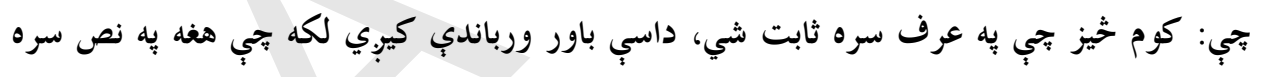

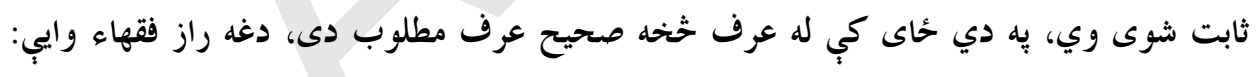

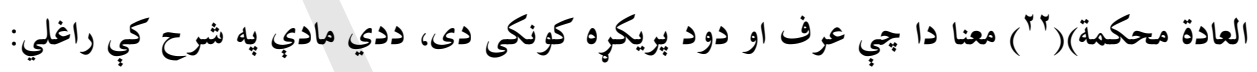

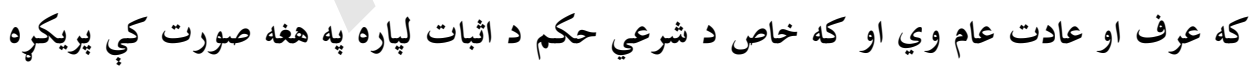

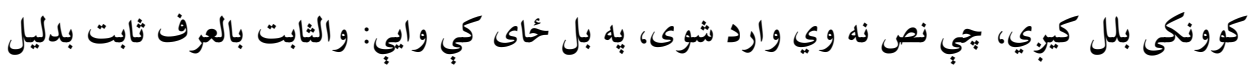

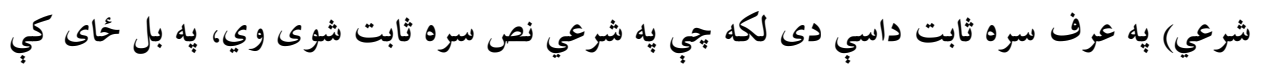

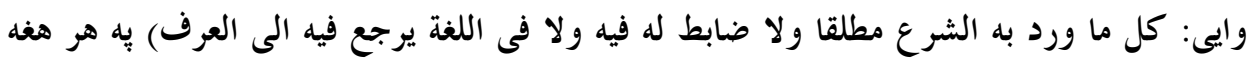

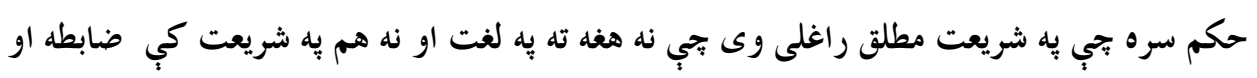

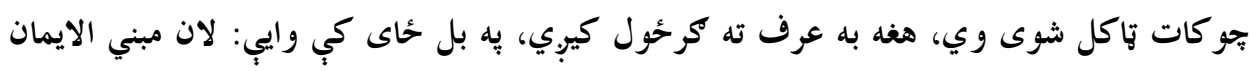

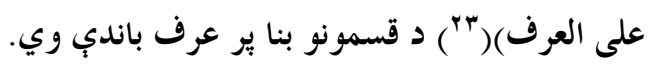




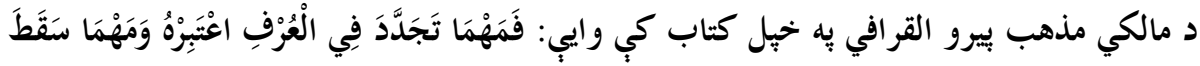

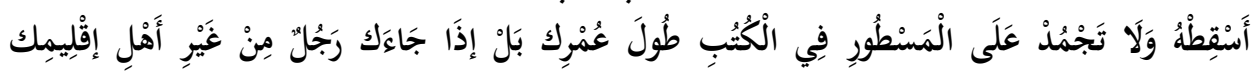

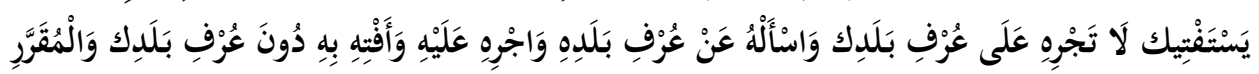

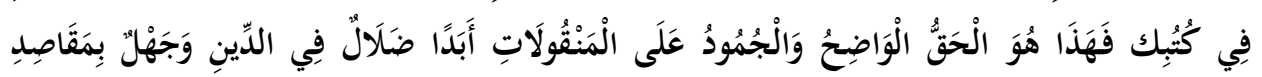

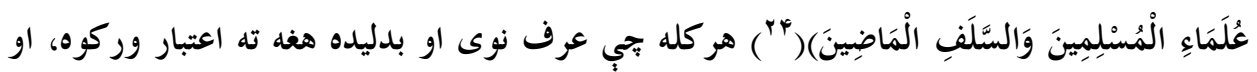

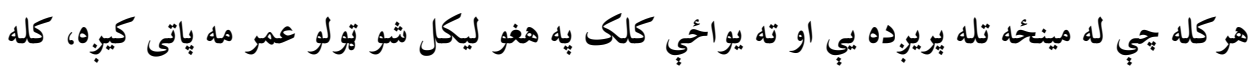

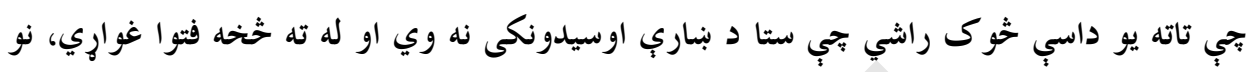

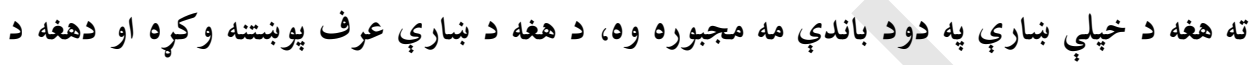

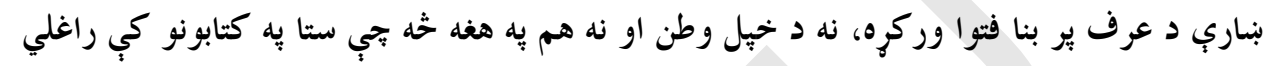

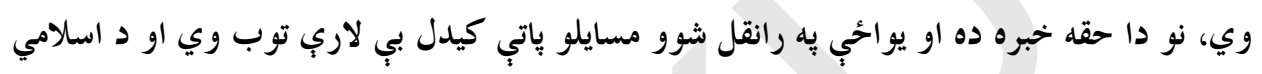
شريعت يوهانو به مقاصدو نه يوهيدل دي.

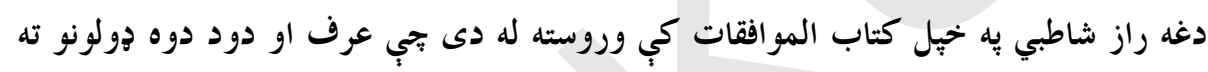

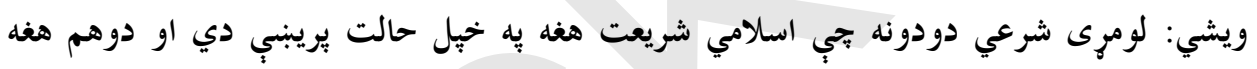

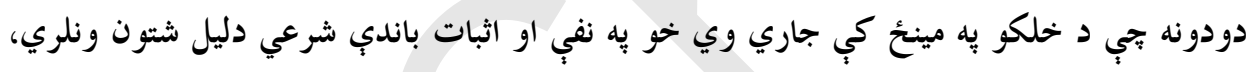

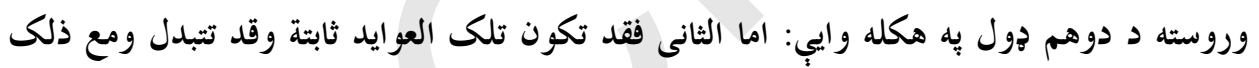

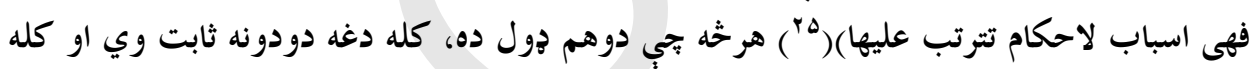

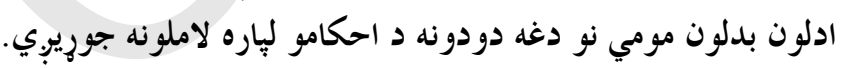

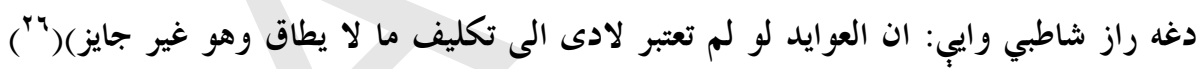

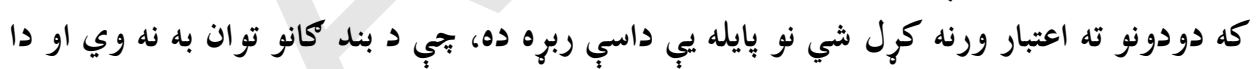
خو درسته نه ده. pr

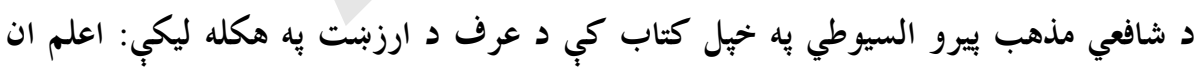

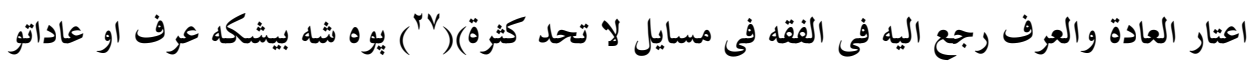

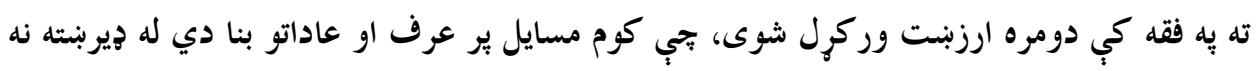
شميرل كيوي.

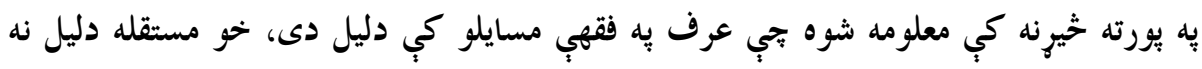

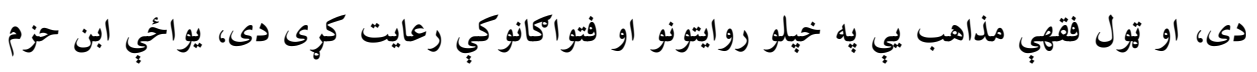


ظاهرى دى تجب به عرف باندي استدلال نه مني، خككه تجي د خلكو ترمينخ خو ظلم او تيرى هم دود وي، يس ايا هغه هم روا كرئي.

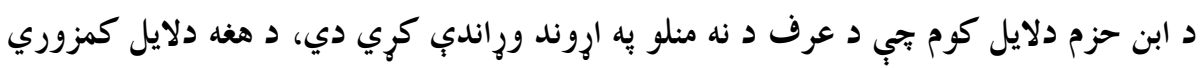

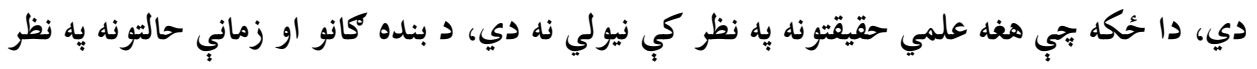

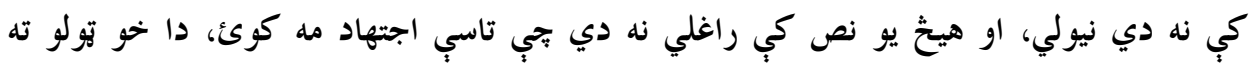

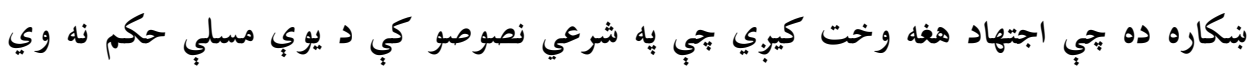

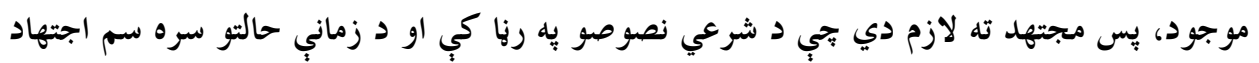

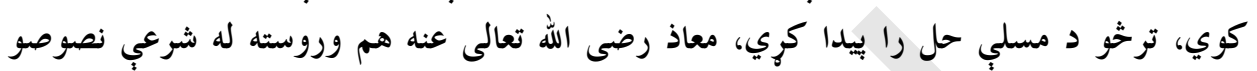

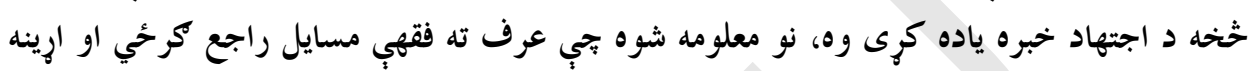

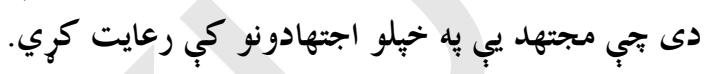

\section{د فرعي احكامو به بدلون كي د عرف ونلده}

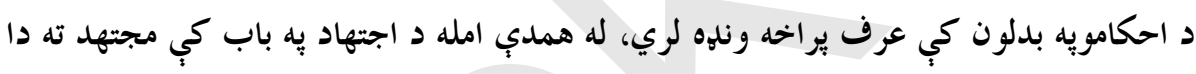

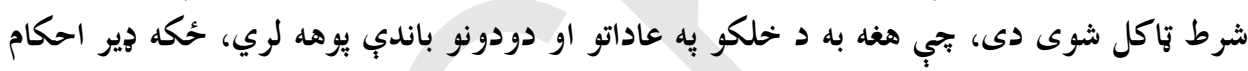

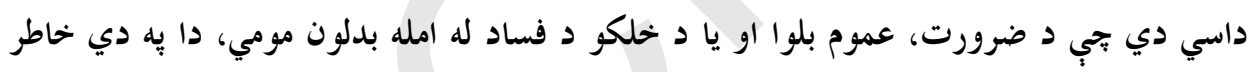

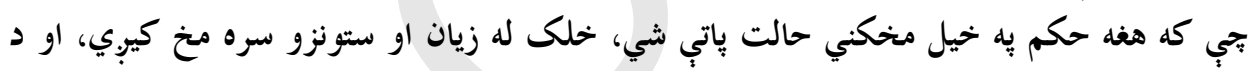

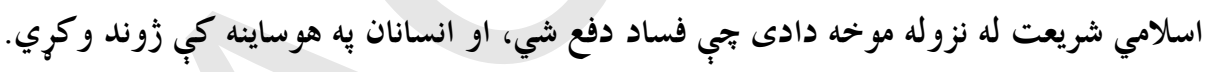

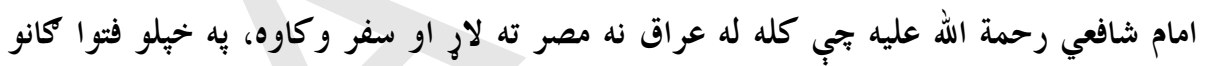

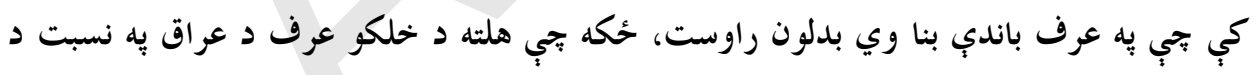

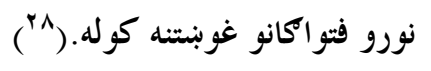

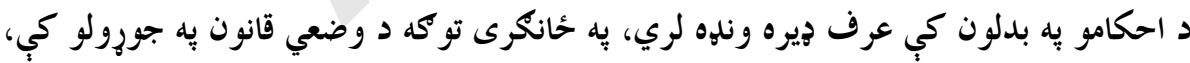

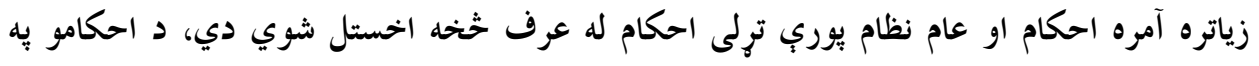

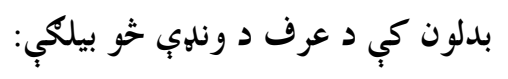

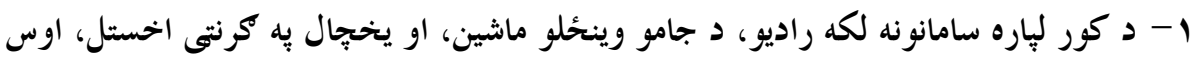

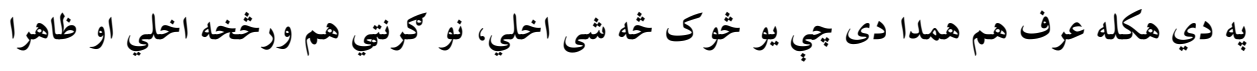

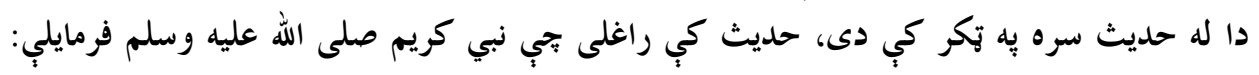




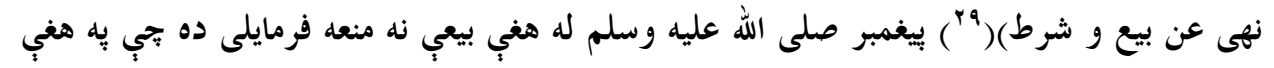
كي شرط كيبنودل شي.

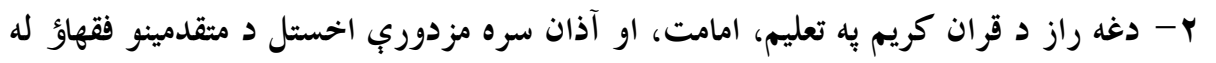

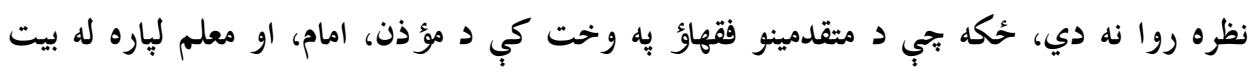

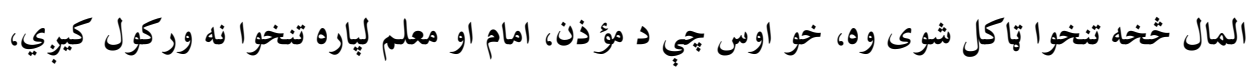

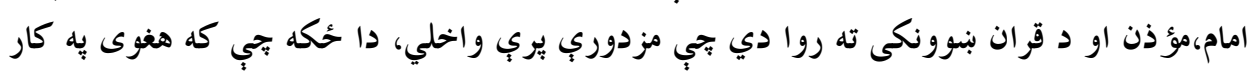
او كسب سره مشغول شي، اسلامي شعاير به ضايع شي.

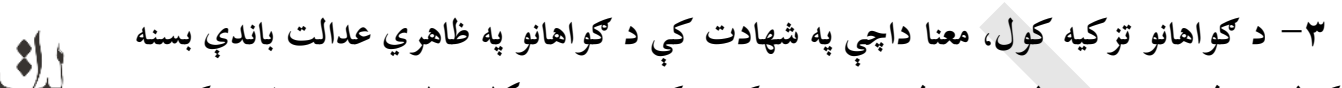

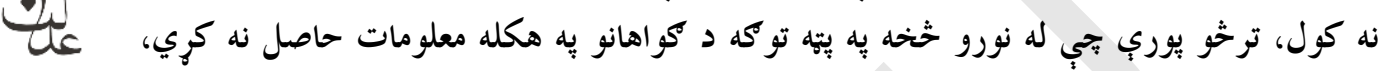

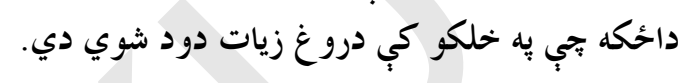

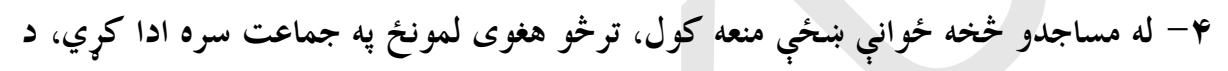

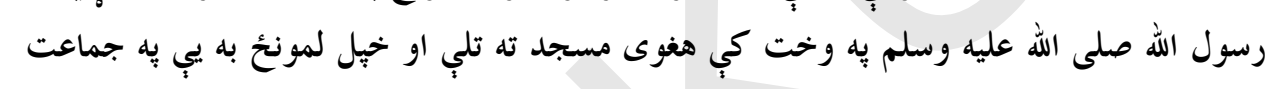

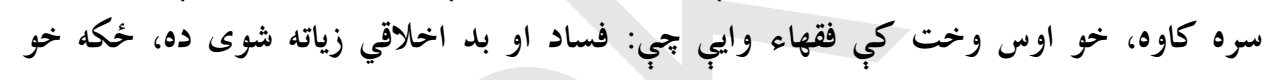
مساجدو ته له تكى خخه منعه شوي دي.

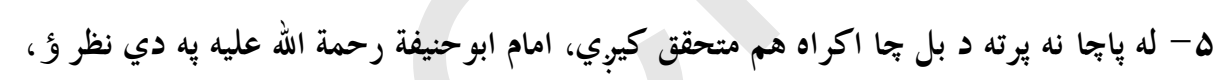

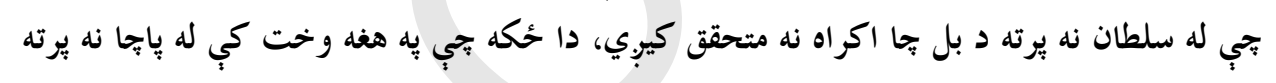

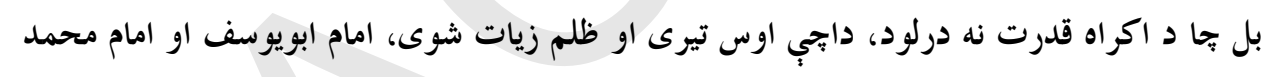

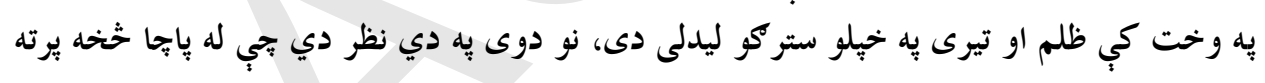

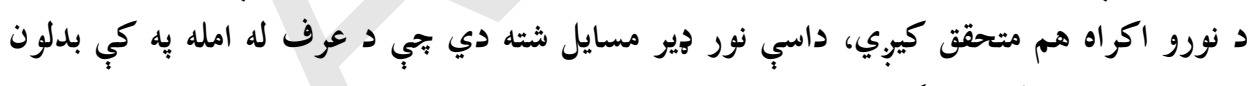

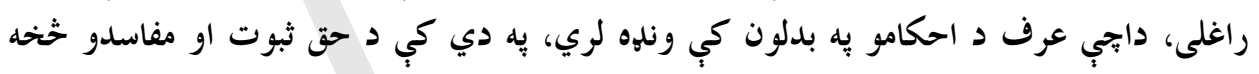

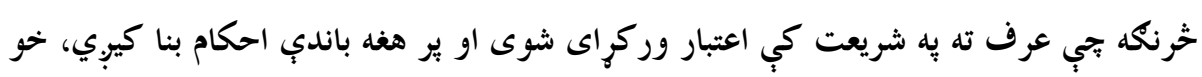

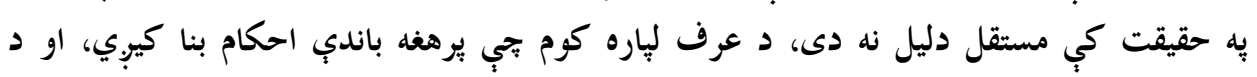

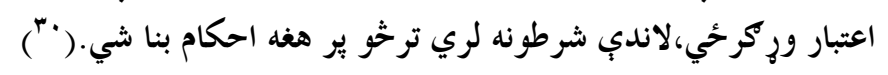

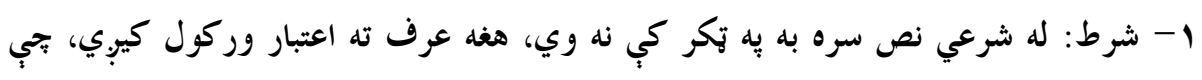

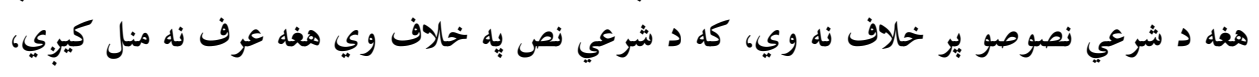

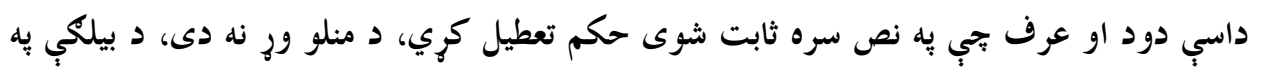


تو كه، سودي معاملات، كانسرت، ككلا كانب، او داسب نور فاسد دودونه او عرفونه، كه جيري نص

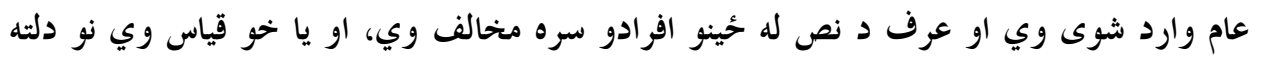

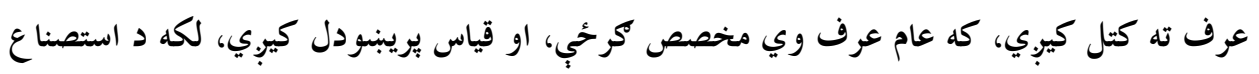
عقد او كه خاص عرف وي، جمهور فقهاء هغه ته اعتبار نه وركوي.

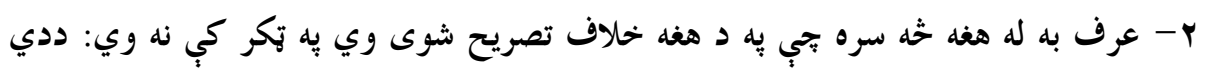

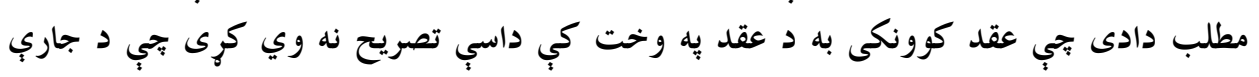

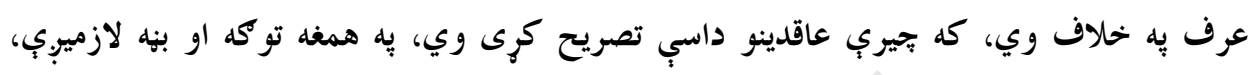

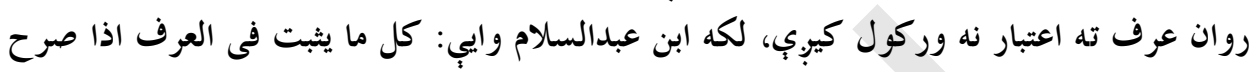

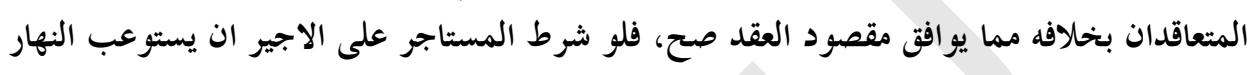

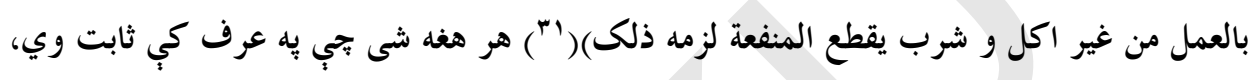

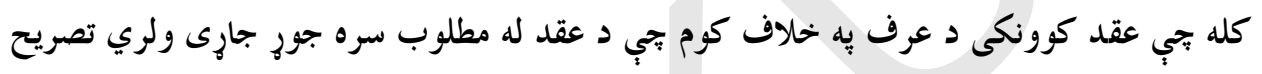

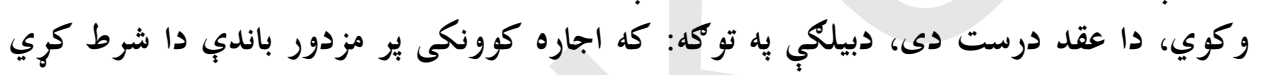

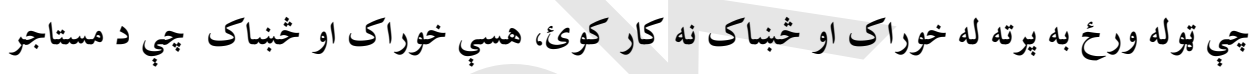

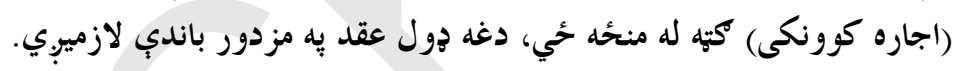

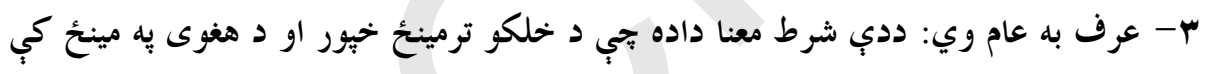

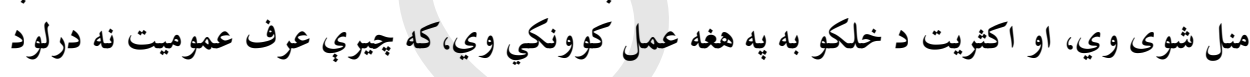

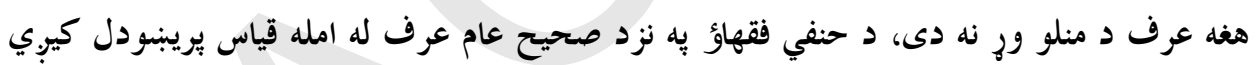

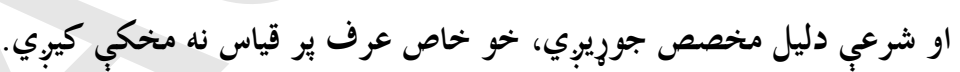

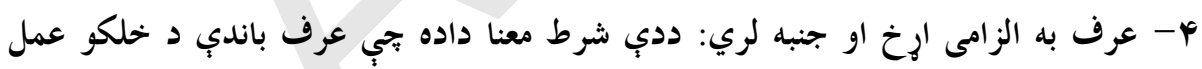
حتمي وي، كه عمل ورباندب ونه شي هغه عرف نه كنل كيري.

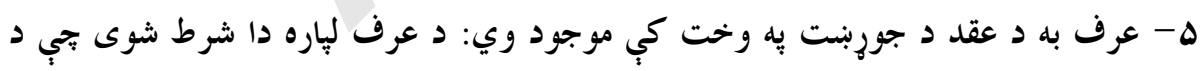

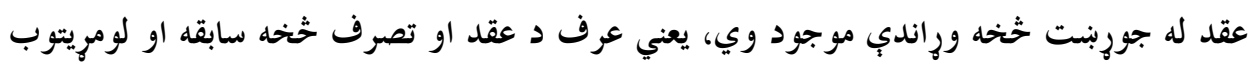

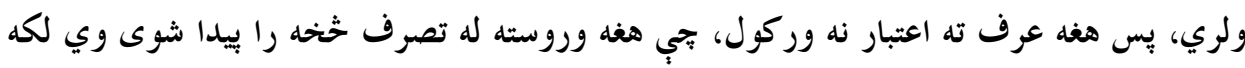

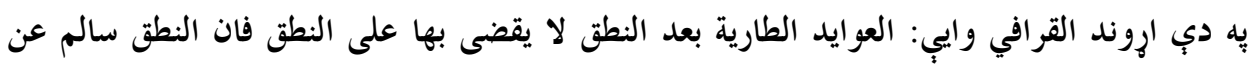

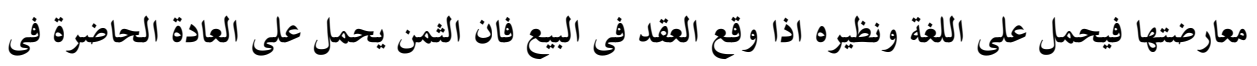

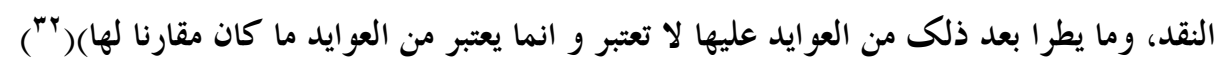


عرف به هغه تصرف او بيبنه باندب دليل نه شي جوريدلای، تي هغه تر عرف مخكي ايجاد

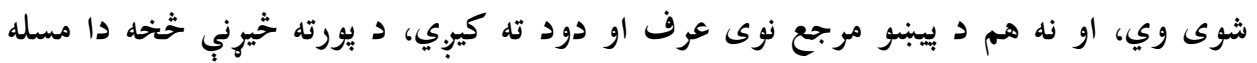

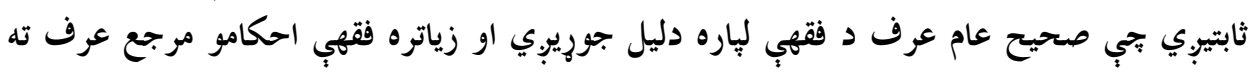
كيري تجب يه دي هكله تول فقهاء اتفاق لري.

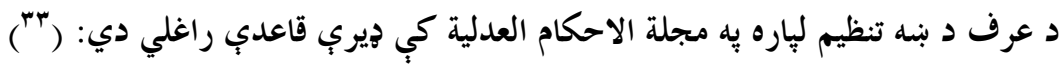

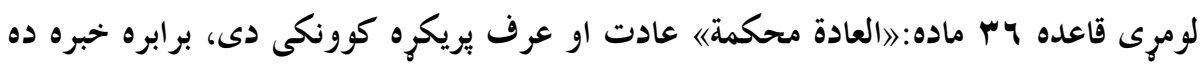
تجي عام وى او كه خحاص وي.

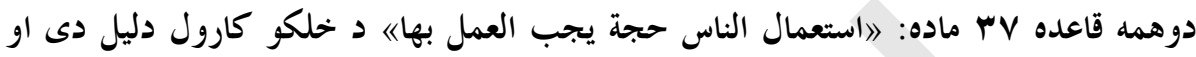
عمل كول ورباندب لازم دي.

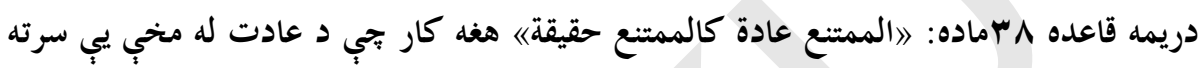

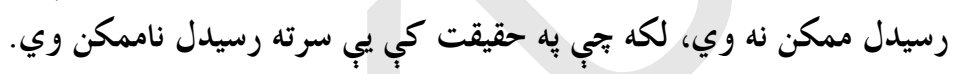

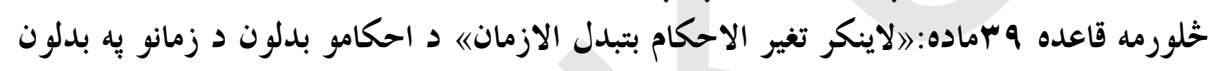
سره ناوره نه كنبل كيوب.

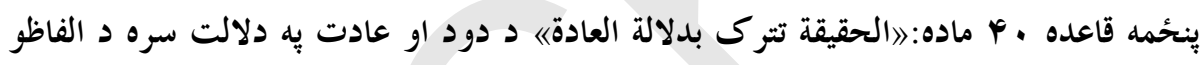
حقيقى معنا يرينبودل كيبوي.

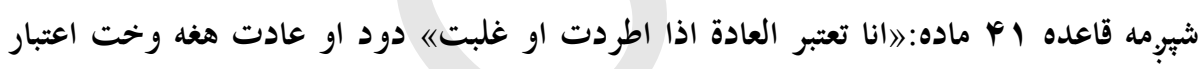
لري، جب د تولنب خلكو كب يب كارول عام او غالب شي.

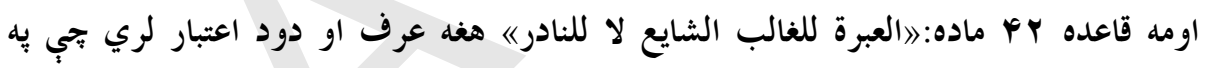

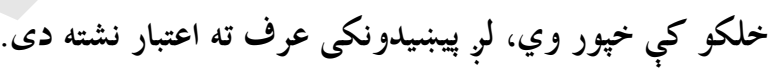

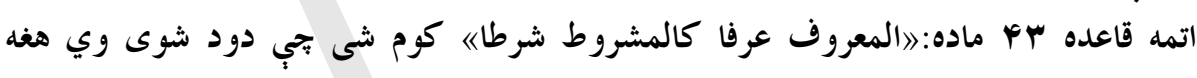

$$
\text { داسب كنل كيبوي لكه جب شرط شوى وي. }
$$

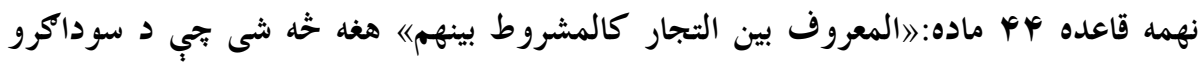

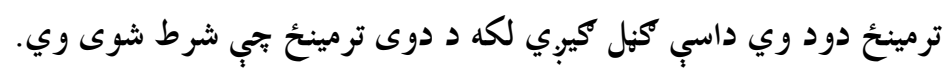

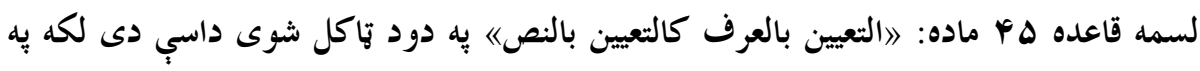
وينا تباكل شوى.

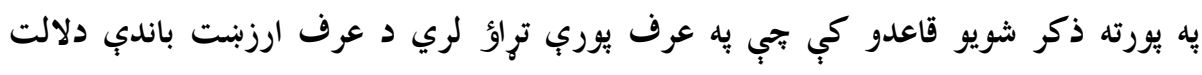




\section{به عرف باندي د بنا شويو احكامو بيلكي:}

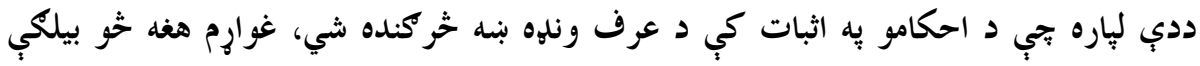

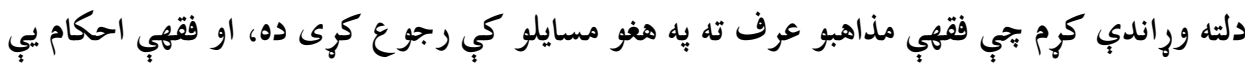

$$
\text { ورباندي بنا كري دي: }
$$

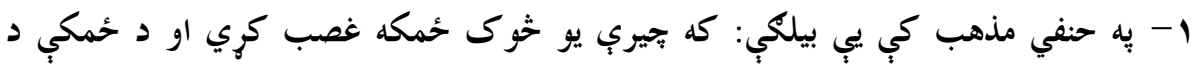

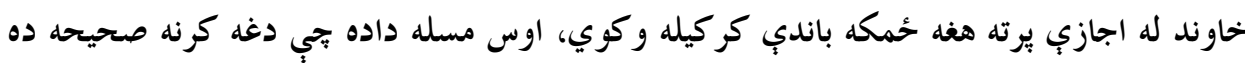

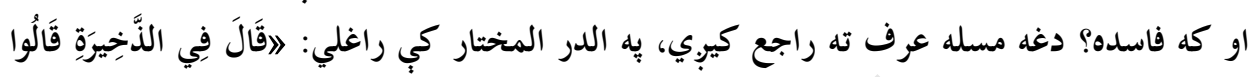

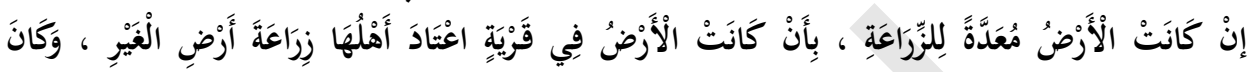

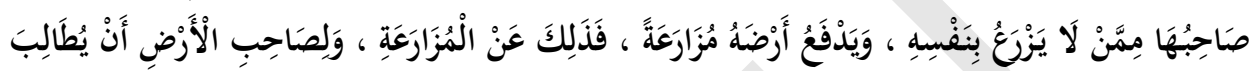

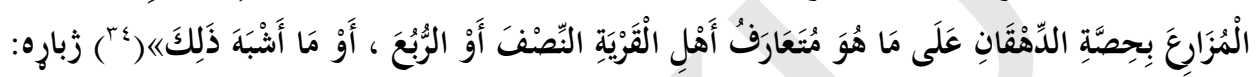

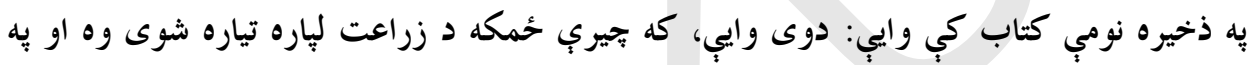

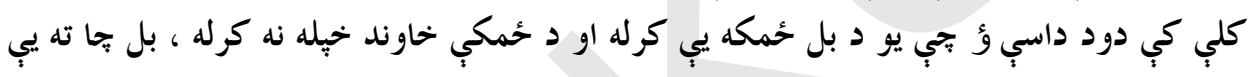

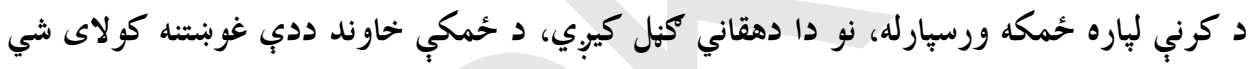

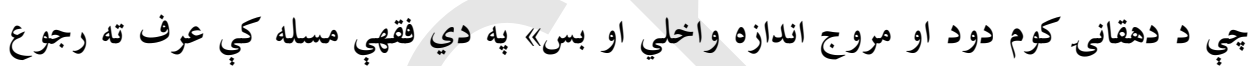
شوى ده.

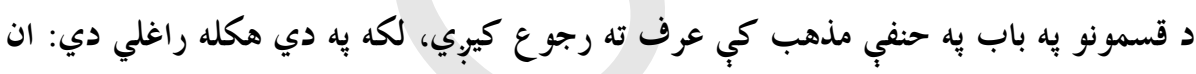

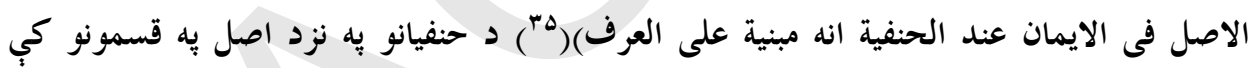

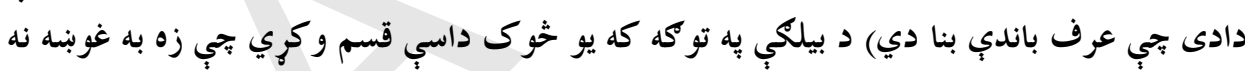

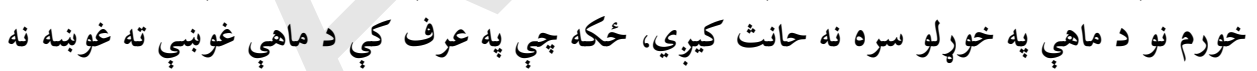

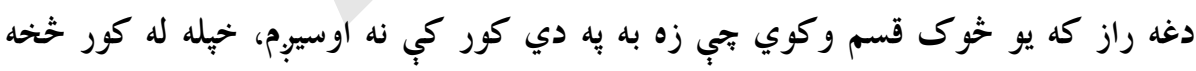

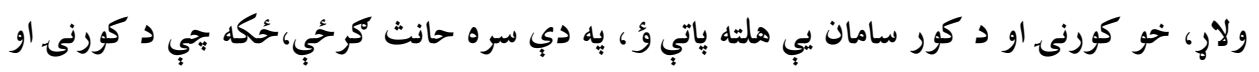

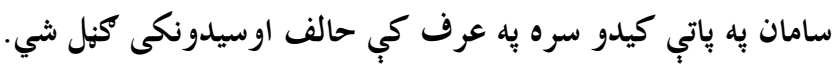

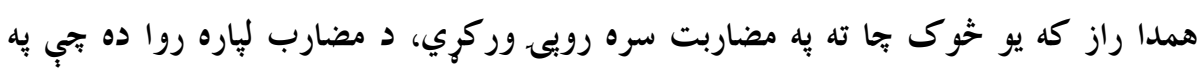

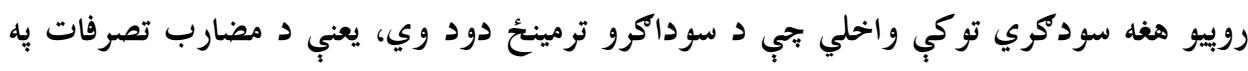
ريبو كي د سوداترو عرف ته راتهرئي 


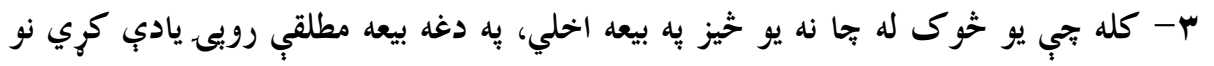

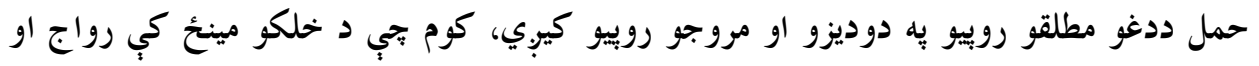

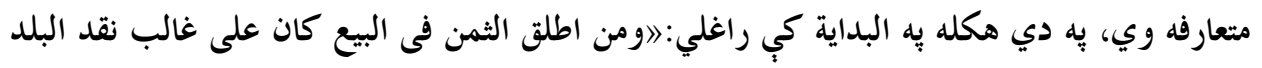

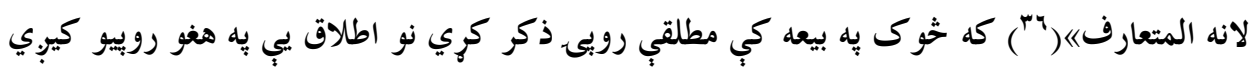
جي بِه بنار كي دود او رواج ولري.

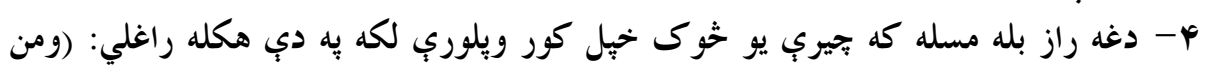

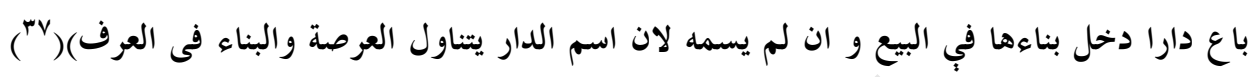

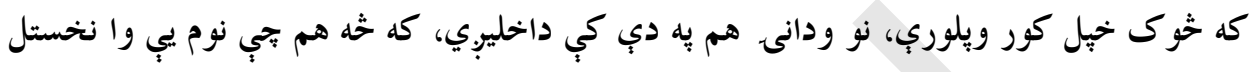

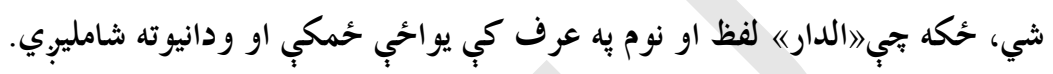

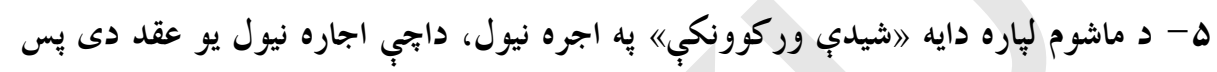

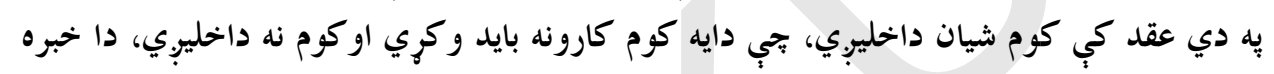

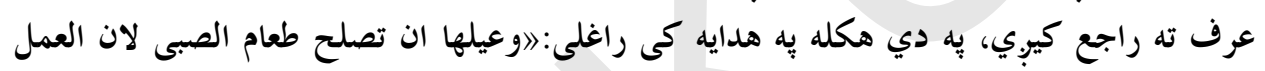

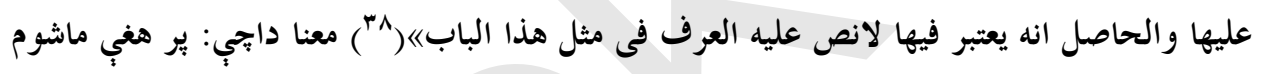

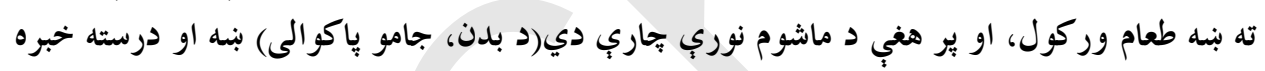

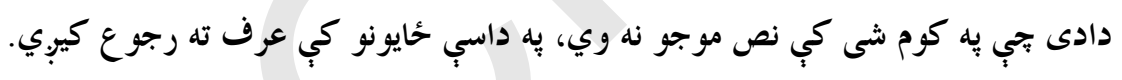

\section{به مالكي مذهب كي بيلكي:}

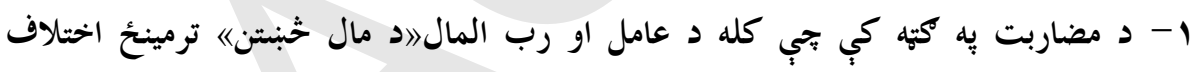

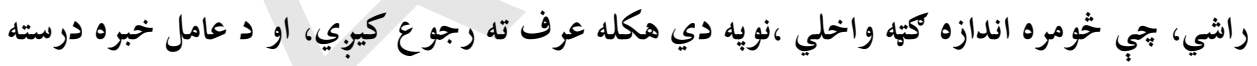

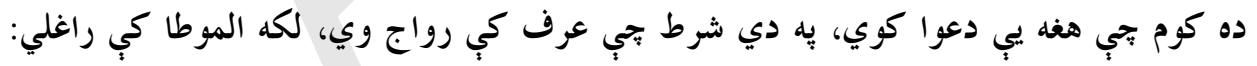

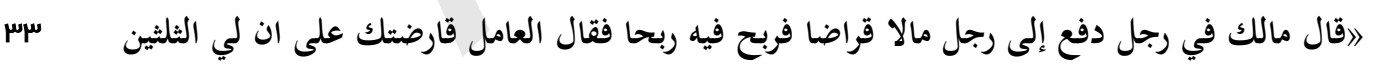

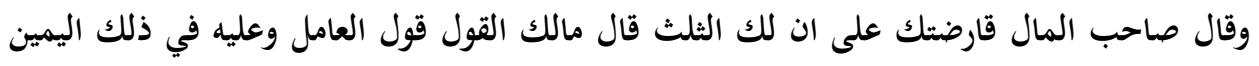

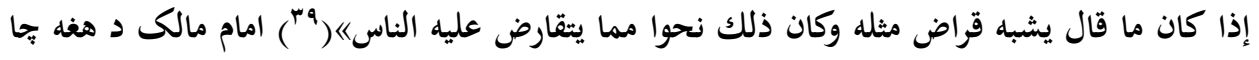

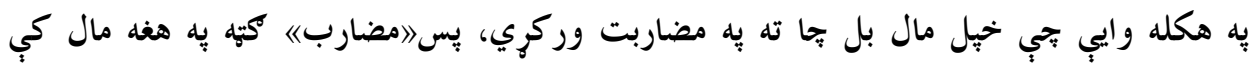

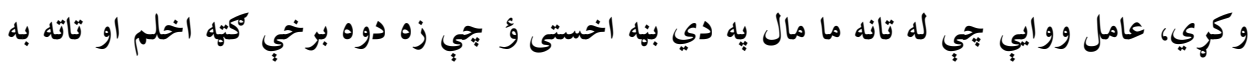

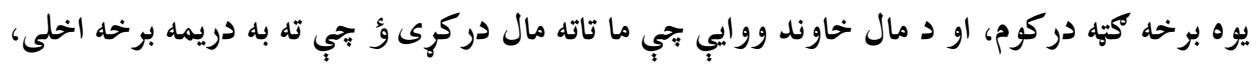


امام مالك وايب تجي دي حاى كي د عامل قول سره له قسمه درست دى، يه دي شرط جب كوم خه

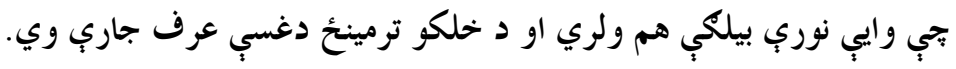

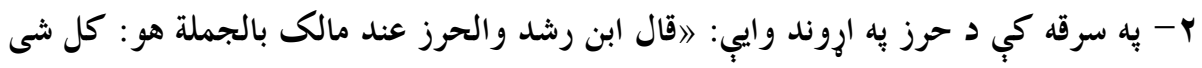

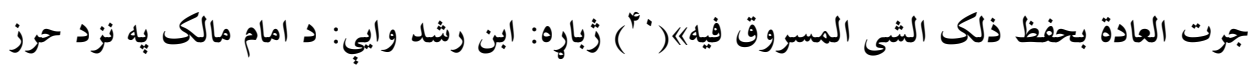

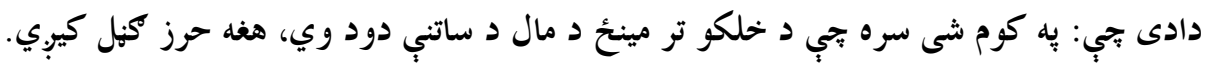

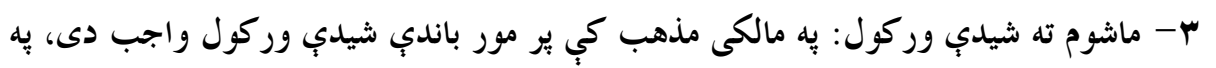

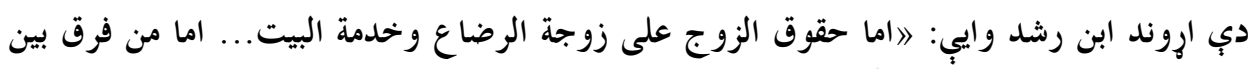

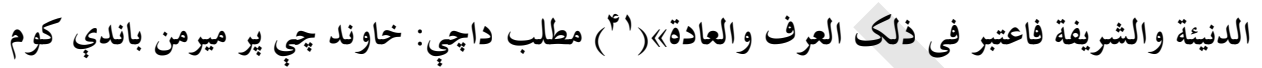

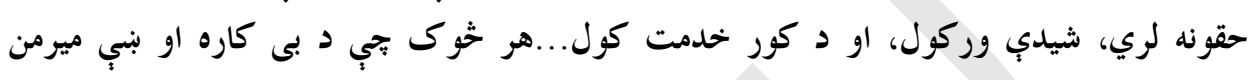

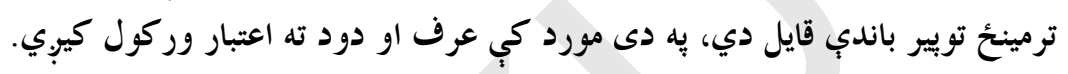

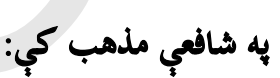

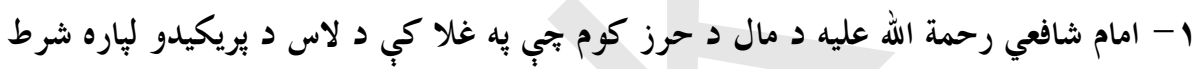

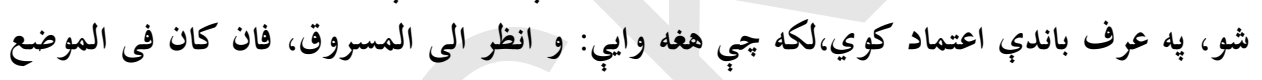

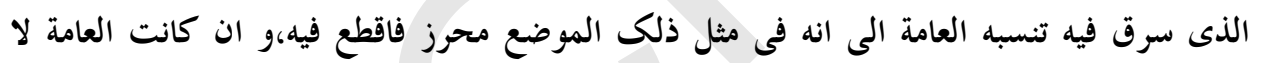

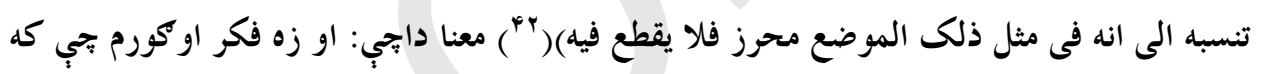

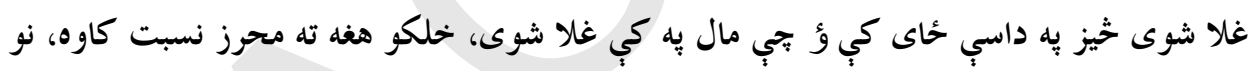

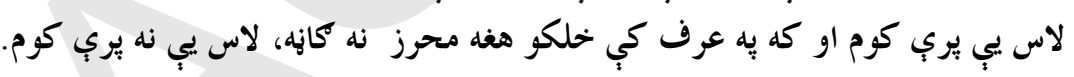

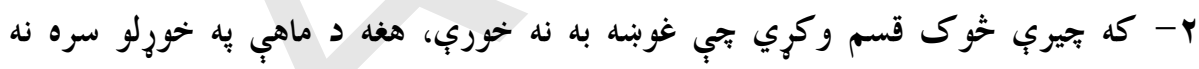

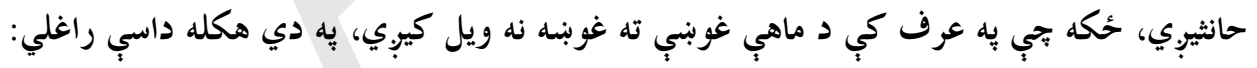

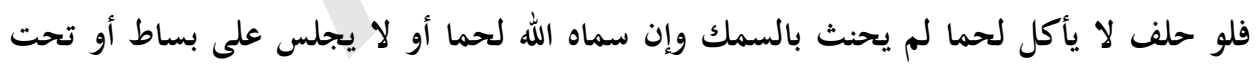

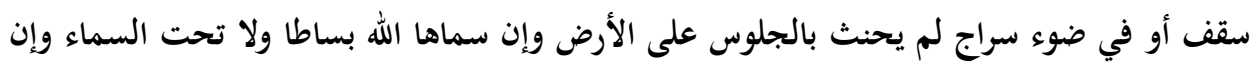

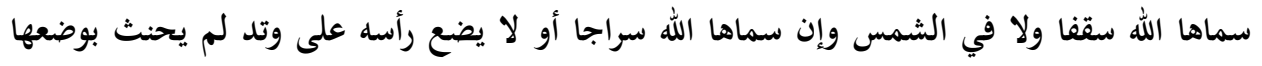

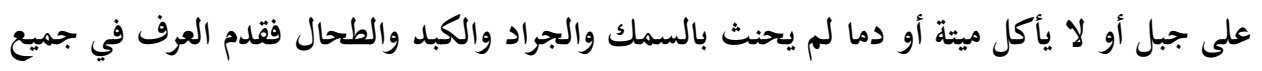

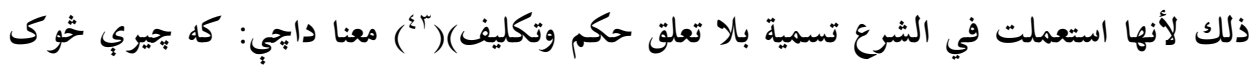

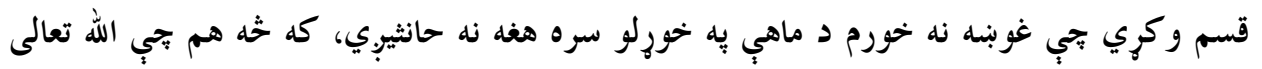

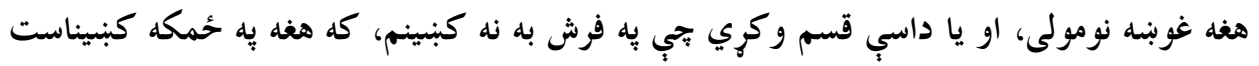


قسم ورباندي نه اوري، كه خه هم حُمكه الله تعالى فرش نومولى ده، همداراز تر اسمان لاندي يه

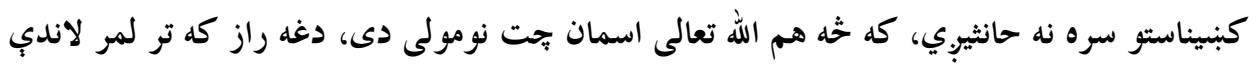

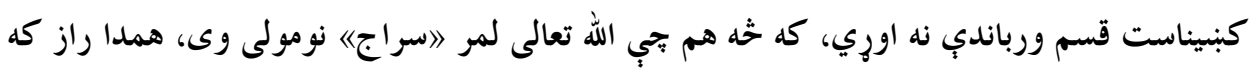

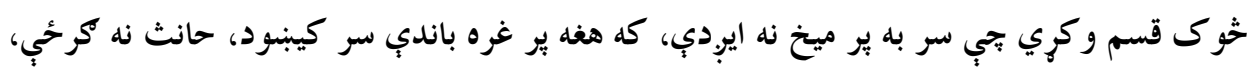

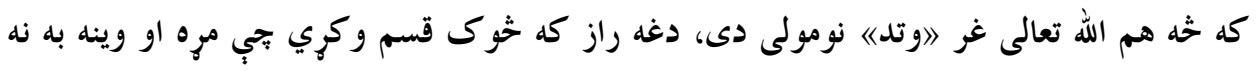

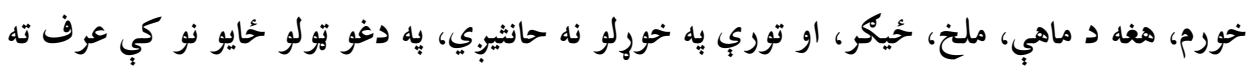

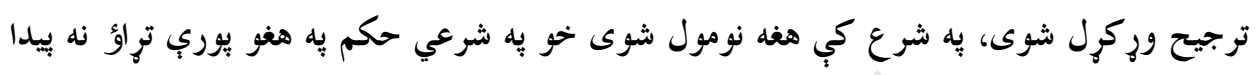

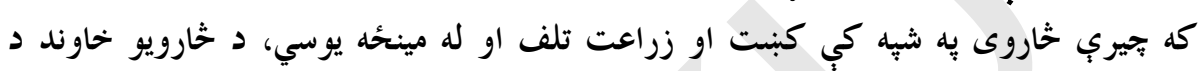

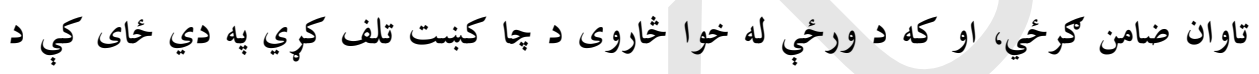

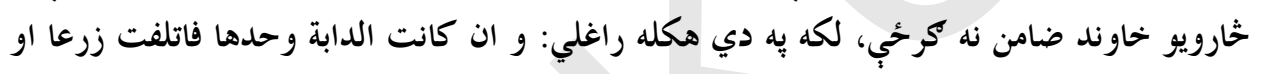

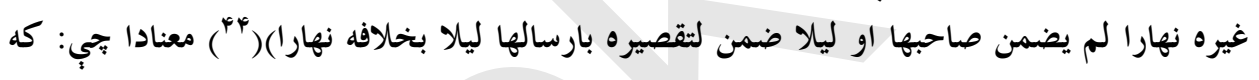

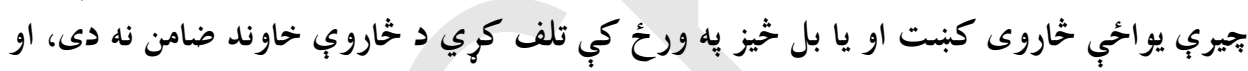

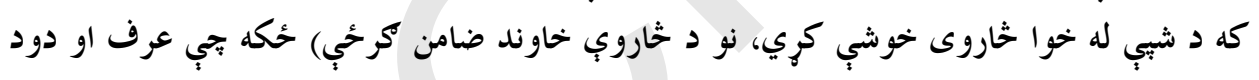

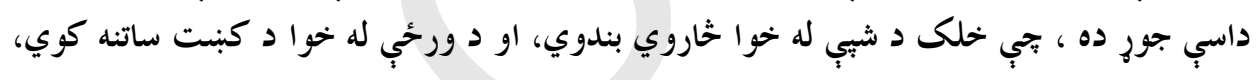

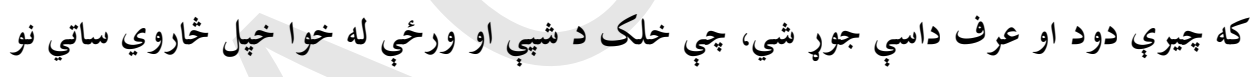

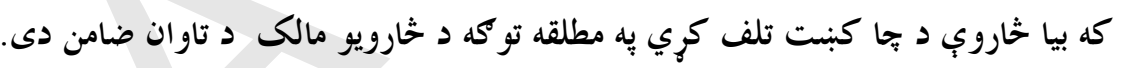

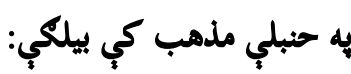

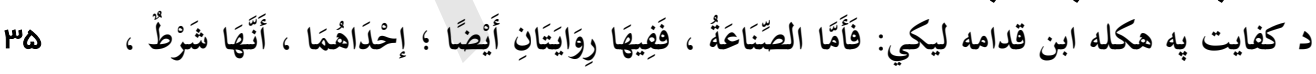

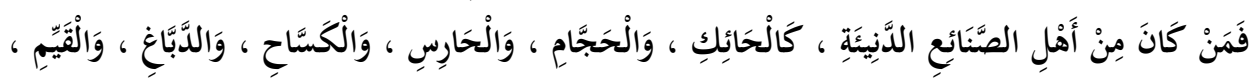

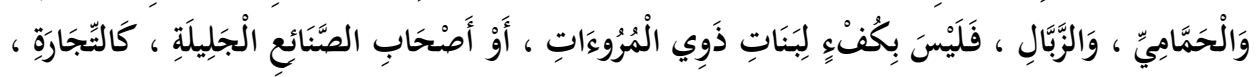

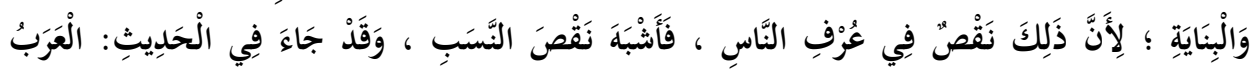

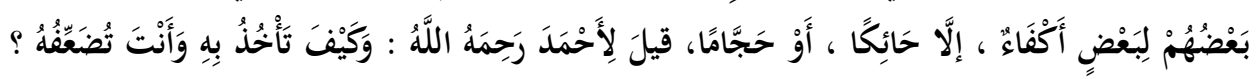

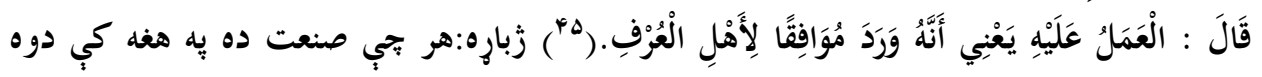

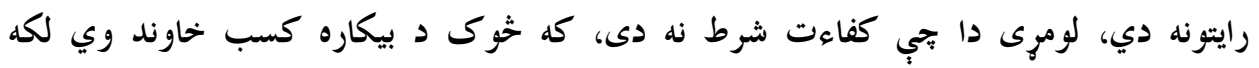


جاروكبن، وينه ويستونكى، رنكمال، سقاؤ او ديران ورونكى، دا د معززو او د بنو كسبونو

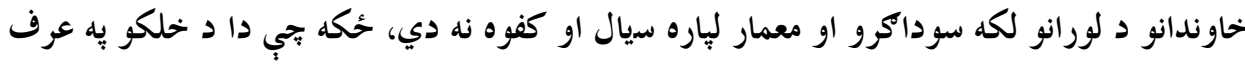

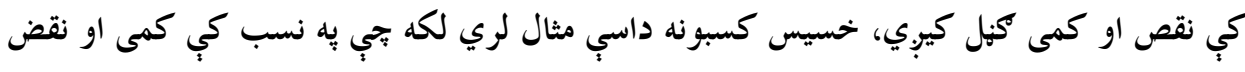

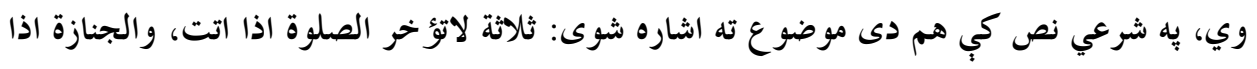

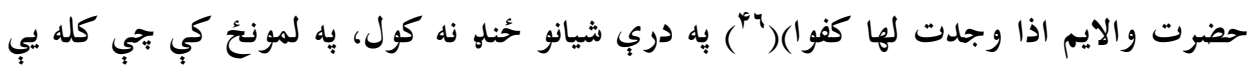

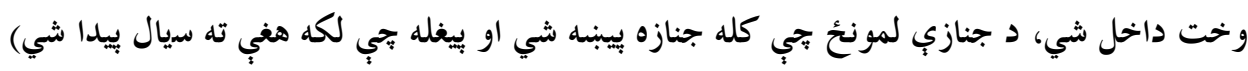

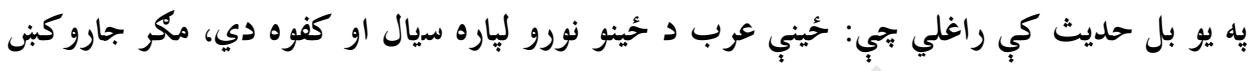

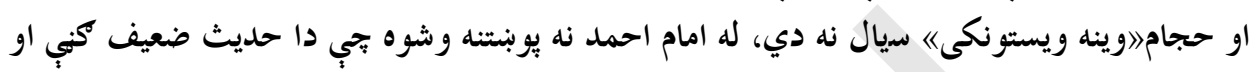

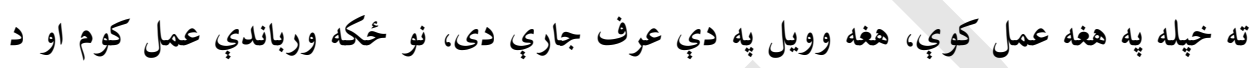
عرف سره برابر دا حديث راغلى.

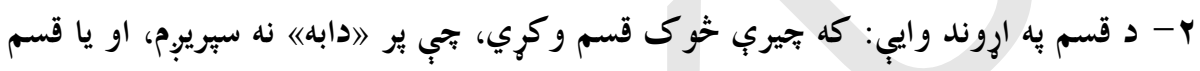

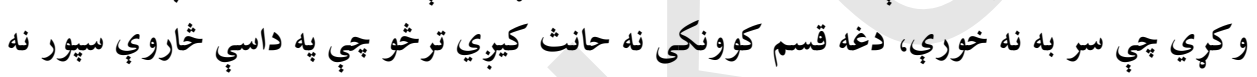

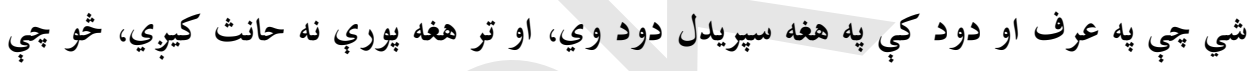

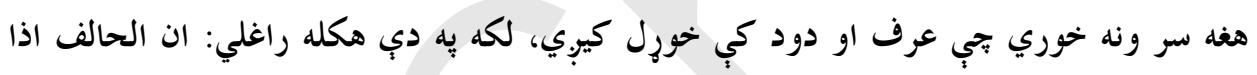

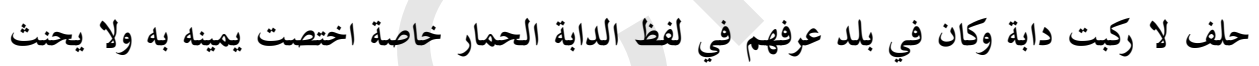
بركوب الفرس ولا الجمل وإن كان عرفهم في لفظ الدابة الفرس خاصة حملت يمينه عليها دون الحمار

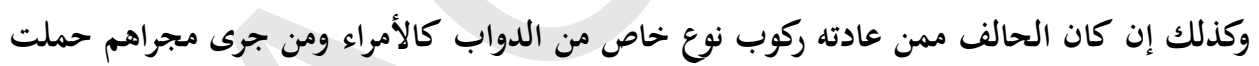

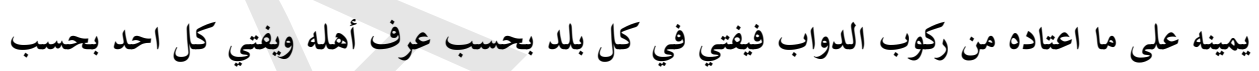

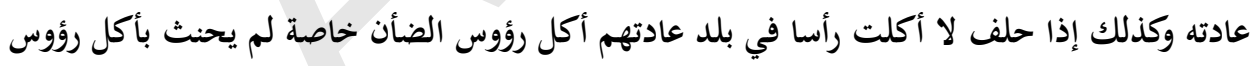

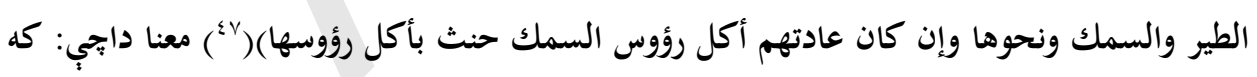

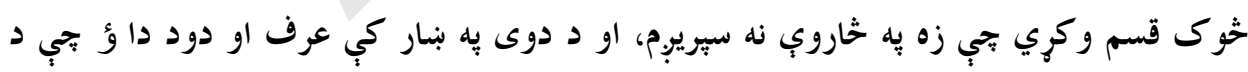

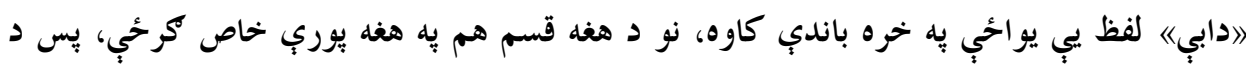

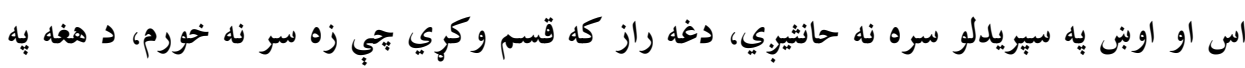

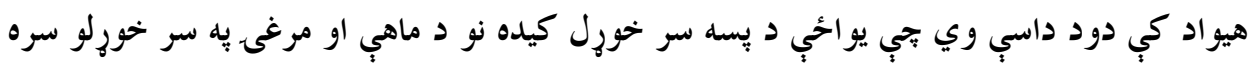

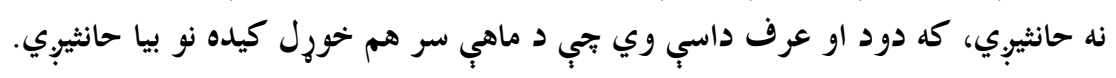

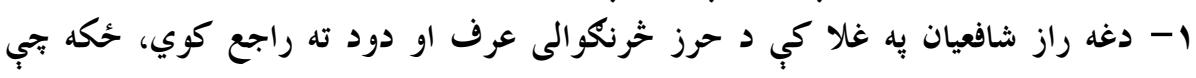

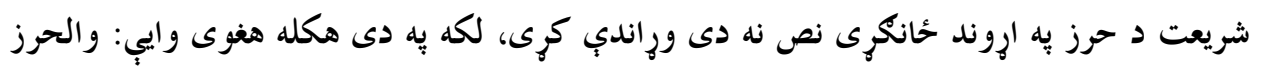


ما عد حرزا فى العرف فانه لما ثبت اعتباره فى الشرع من غير تنصيص على بيانه، علم انه رد ذلك الك الح

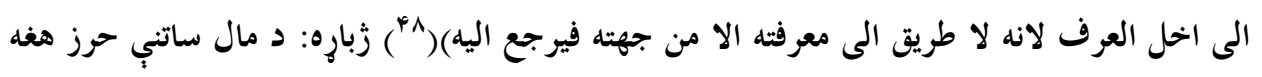

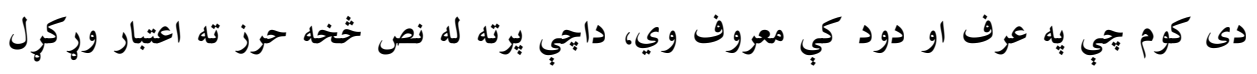

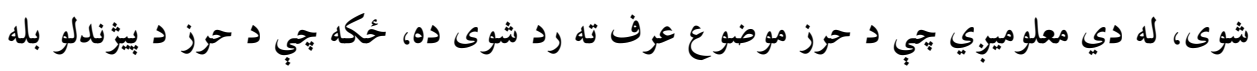

$$
\text { لاره شتون نه لري. }
$$

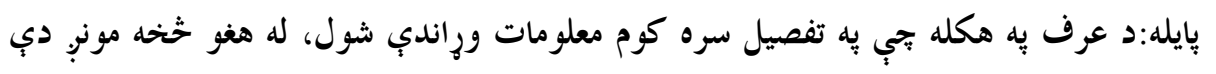

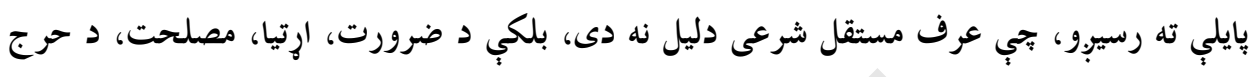

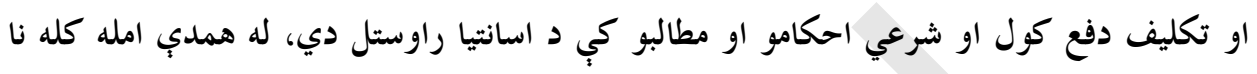

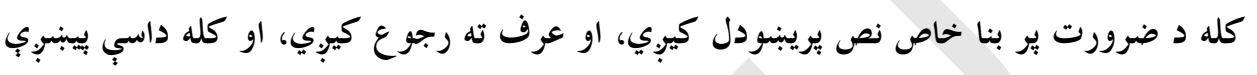

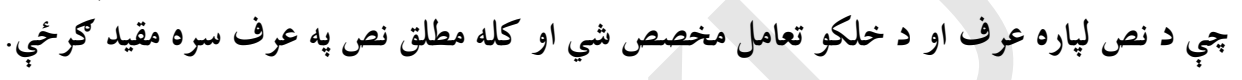

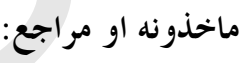

1-فرهنك جامع نوين، ترجمه المنجد عربي، مترجم احمد سياح، انتشارات اسلام، دويم جز، وه ب امخخ.

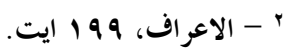

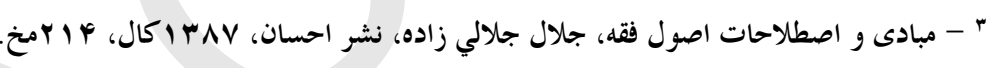

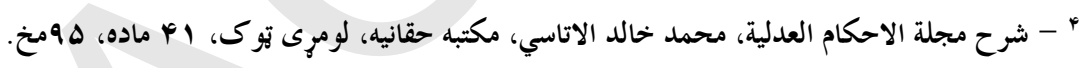

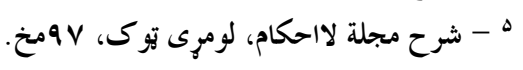

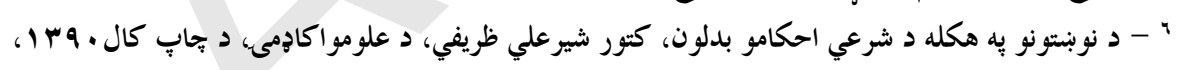

$$
\begin{aligned}
& \text { ميخ } \\
& \text { v - المدثر، هايت. } \\
& \text { ^ - التوبة، م ـ ا ايت. }
\end{aligned}
$$

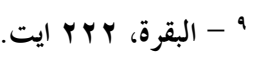

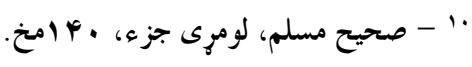

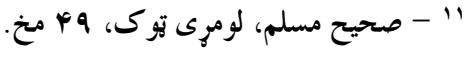

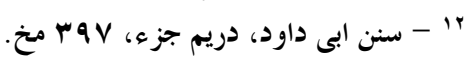

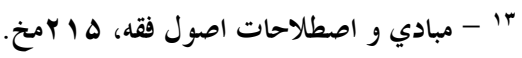

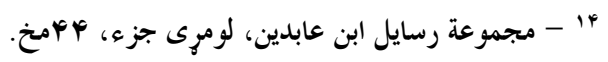




$$
\begin{aligned}
& \text { ها - الطلاق، V ايت. }
\end{aligned}
$$

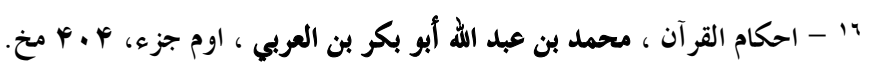

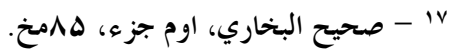

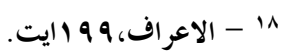

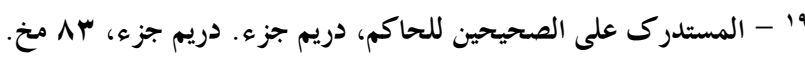

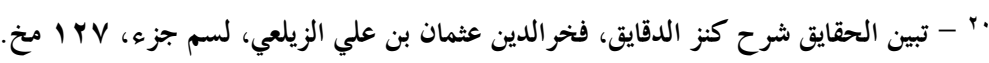

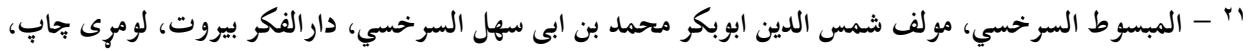

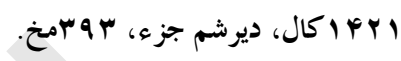

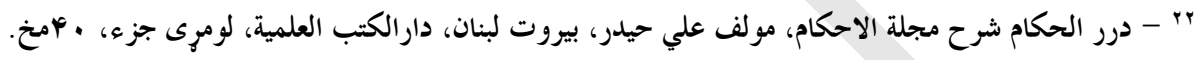

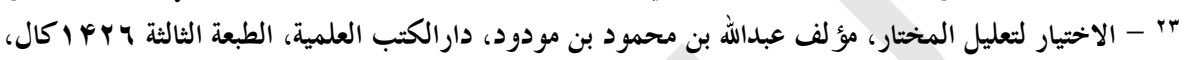
خلورم جزء، بآمخح.

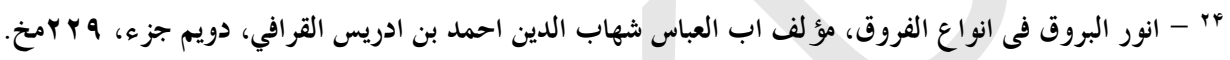

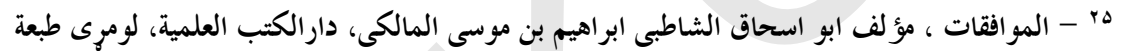

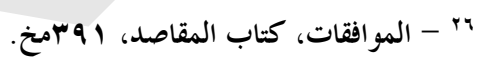

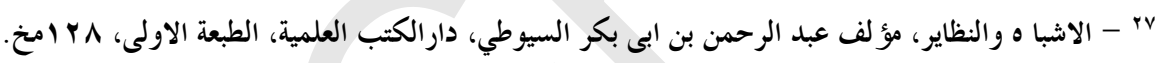

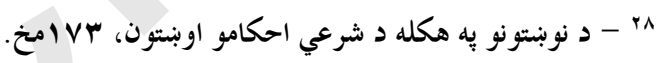

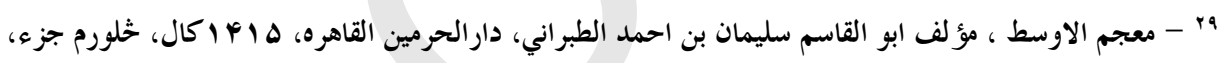

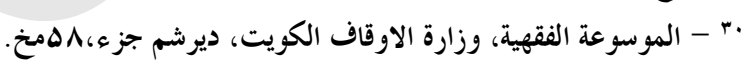

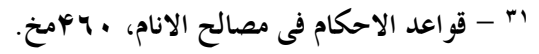

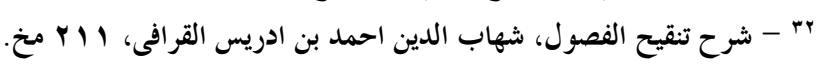

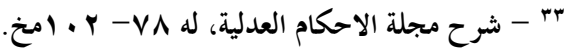

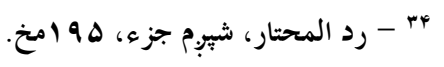

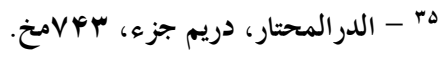

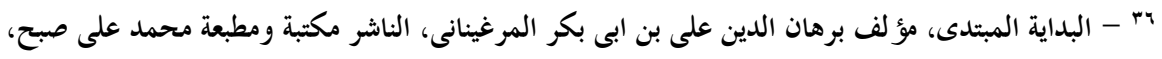




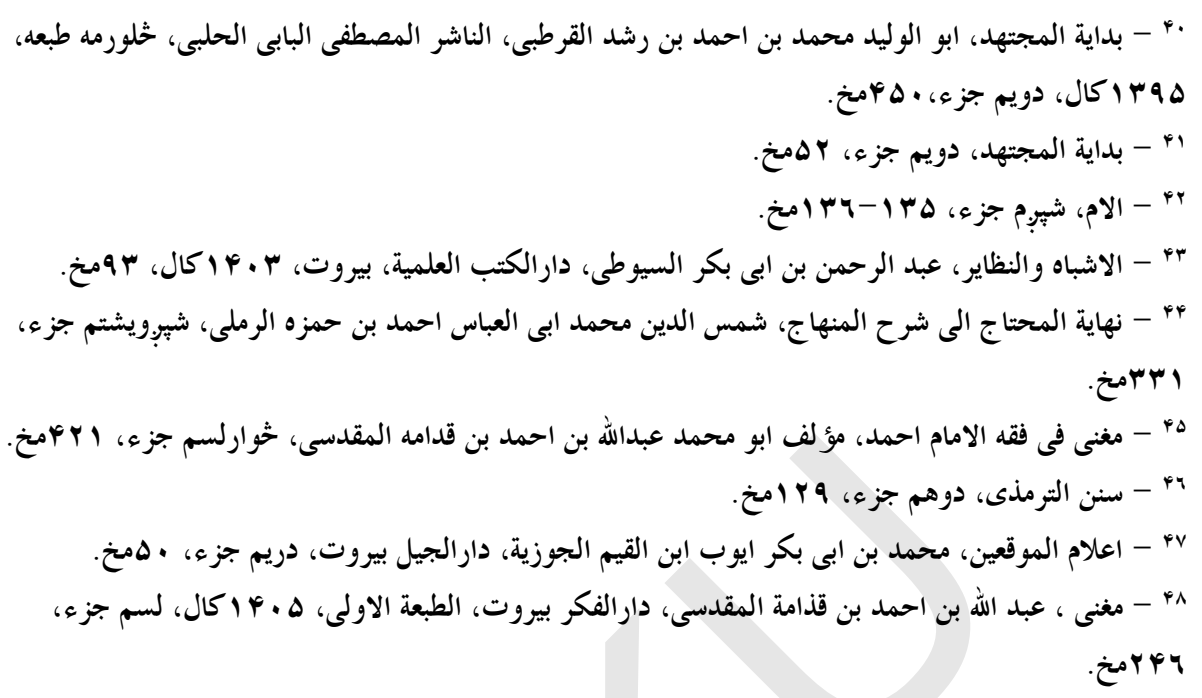

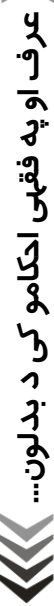

нq 


\section{حمايت از حقوق مالكيت فكرى در حقوق افغانستان}

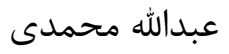

جكيده:

حقوق مالكيت فكرى، مفهوم حقوقى نوينى است كه /ز فعاليتها و محصولات فكرى در

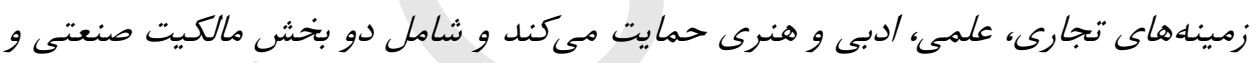

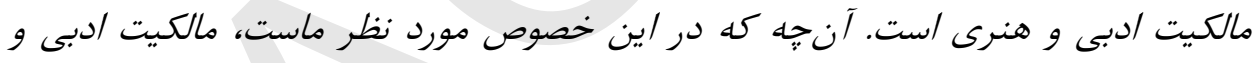

هنرى /ست.

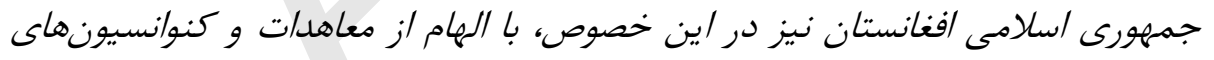

بين الملى در زمينه حقوق مالكيت فكرى به تدوين اصول و مقررات حمايتى از /ين حقوق در قوانين خويش برداخته /ست. در قانون حمايت /ز حقوق مولف، مصنف، هنرمنل و محقق

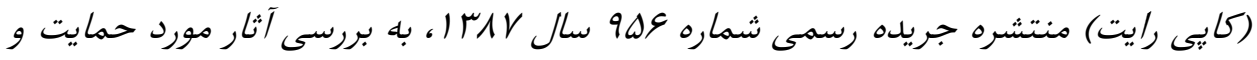

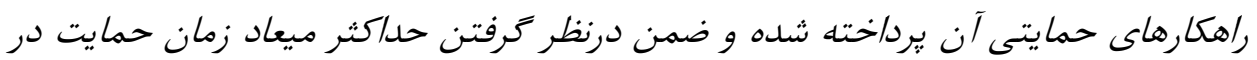

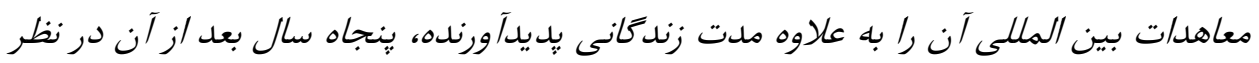


كرفته /ست. همجنين تدابير بازدارنده و ضمانت اجرايى براى حمايت /ز آن مقرر داشته /ست كه به حبس و جريمه نقدى مى توان اشاره نمود. وازكان كليدى: حقوق مالكيت فكرى، حقوق مالكيت ادبى و هنرى، نقض حقوق مالكيت فكرى، مالكيت ادبى و هنرى حوق مال

\section{مبحث اول: حقوق مالكيت فكرى}

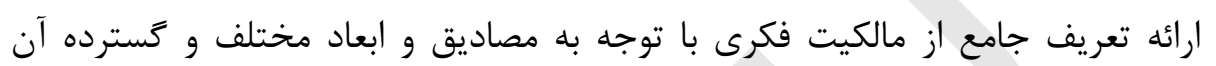

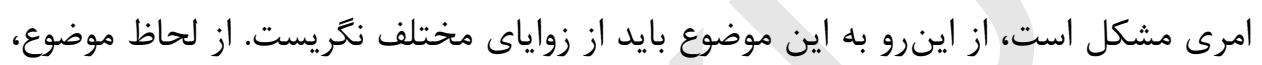

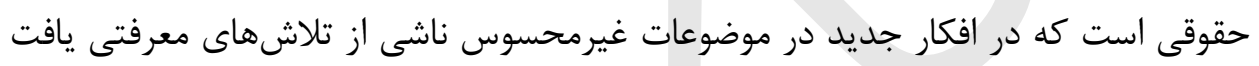

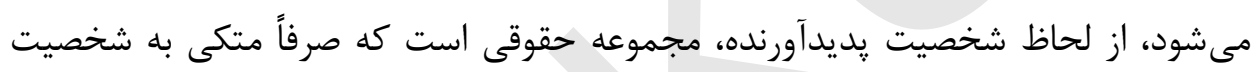

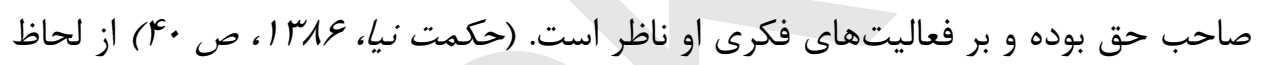
احكام مربوطه به مالكيت فكرى، به مجموعه حقوق بهرهبردارى انحصارى از نتايج خلاقيت-

$$
\text { هاى فكرى تعبير مىشود. }
$$

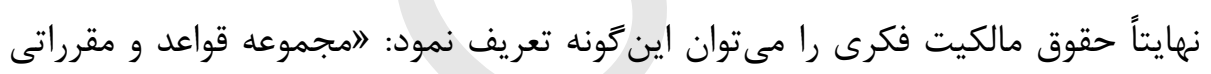

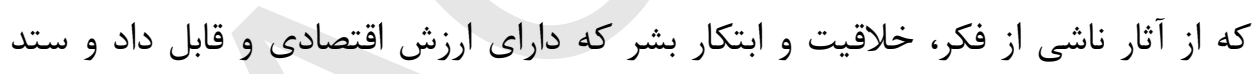

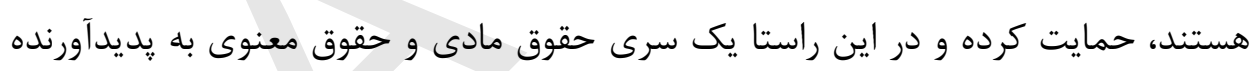
آن اعطاء مىنمايد. همايت كرده

دافر موافقتنامه راجع به جنبههاى تجارتى حقوق مالكيت فكرى (تريبس :

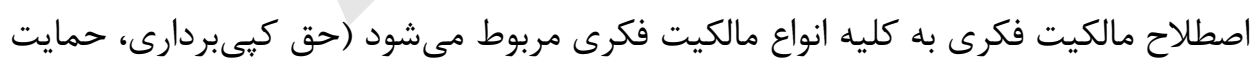

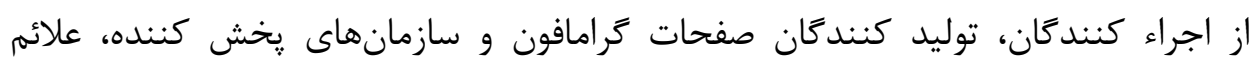

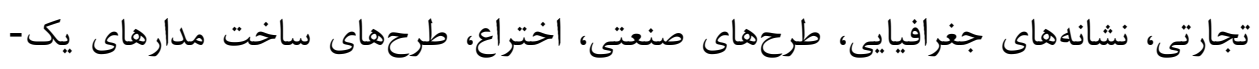
پار جه و حفاظت اطلاعات افشاء نشده).

حقوق مالكيت فكرى را بصورت معمول به دو قسم، حقوق مالكيت صنعتى و تجارتى و حقوق مالكيتهاى ادبى و هنرى تقسيم بندى نمودهاند. 
از مصداقهاى معمول حقوق مالكيت صنعتى و تجارتى مى توان به علايم تجارتى و

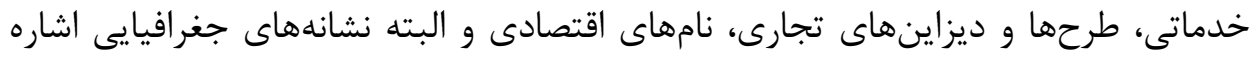

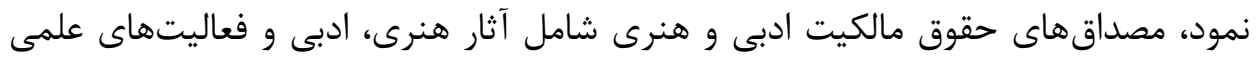
مانند كتابها، نقاشىها و طرحها، عكسها يا نغارهها و ... مى باشد.

\section{Industrial property, page ${ }^{\mathrm{k}}$ )}

\section{كفتتار دوم: جايعاه حقوق مالكيت فكرى}

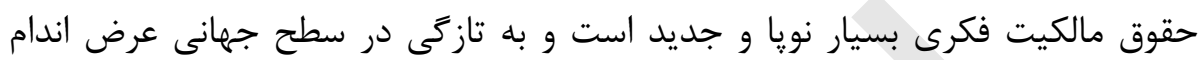

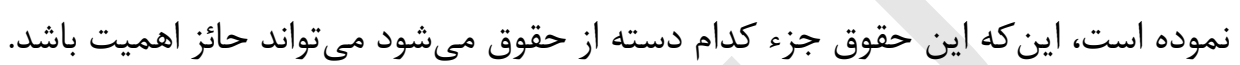

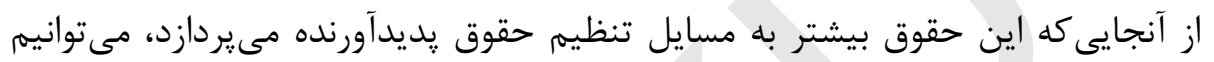

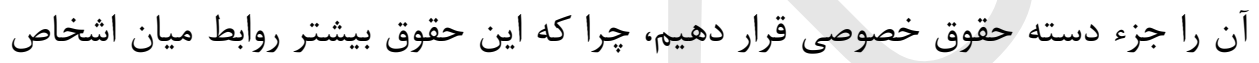

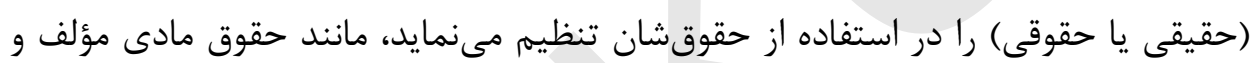

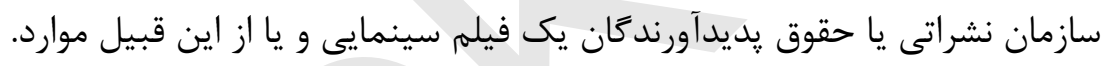

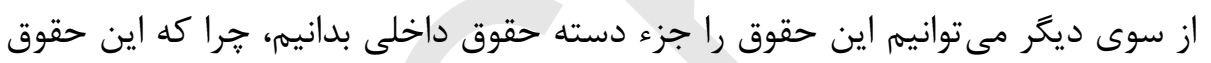

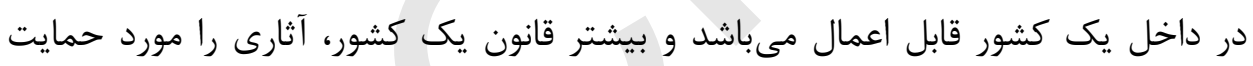

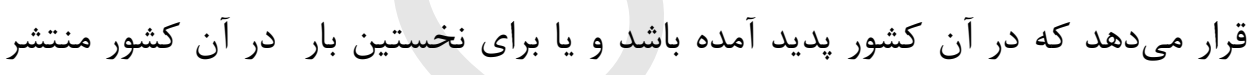

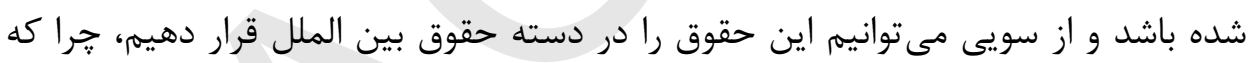

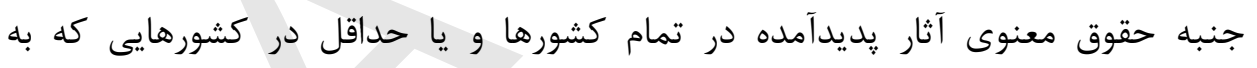

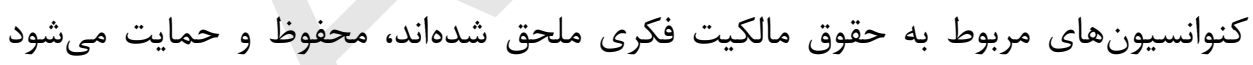

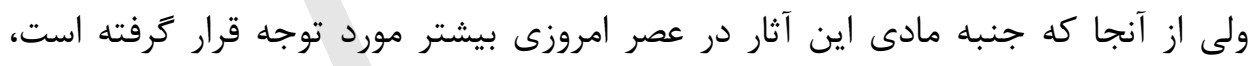

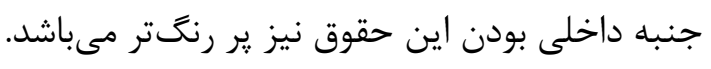

\section{مبحث دوم: حمايت از حقوق مالكيت فكرى در حقوق افغانستان}

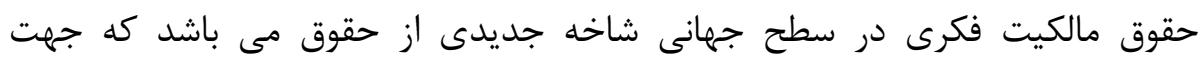

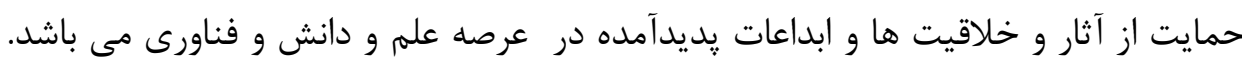

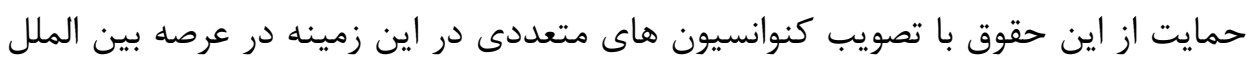

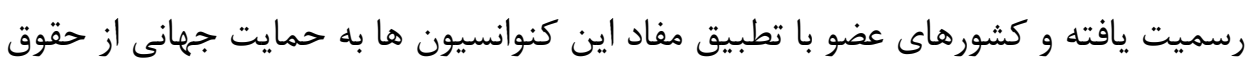


مالكيت فكرى اهتمام ورزيده اند. از جمله مهمترين اين كنوانسيون ها مى توان به

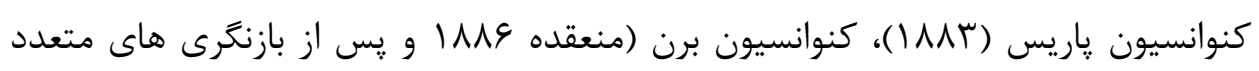

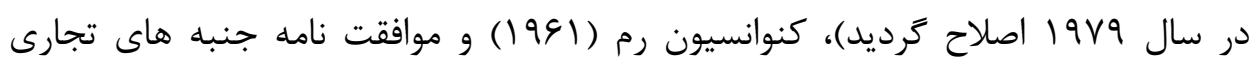

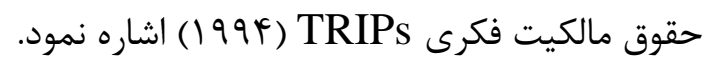

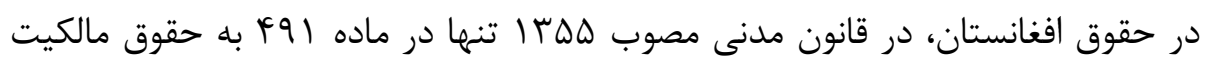

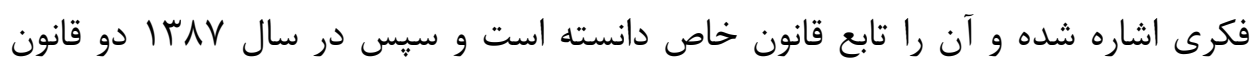

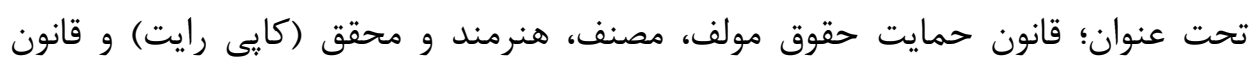

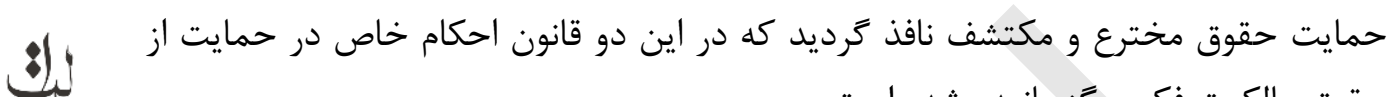
حقوق مالكيت فكرى كَنجانيده شده است.

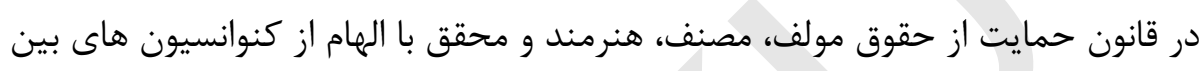

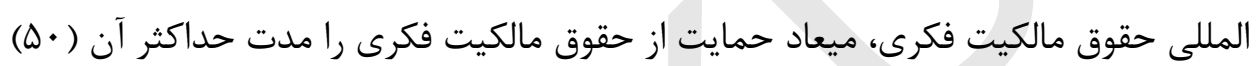

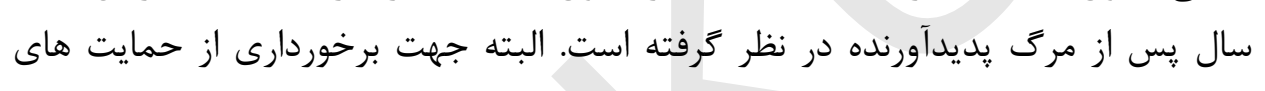

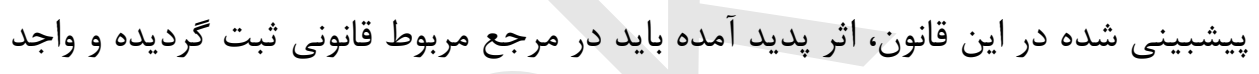
شرايط حمايت اين قانون گردد.

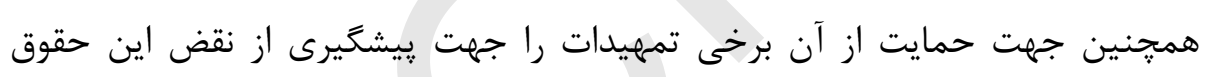

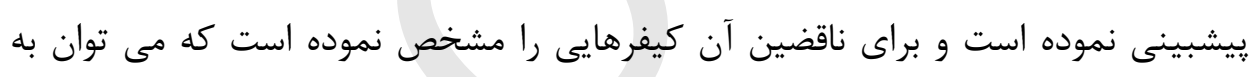

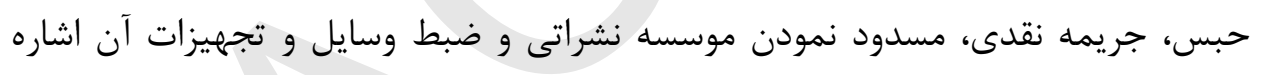

\section{كفتار اول: مدت حمايت}

منظور از مدت حمايت، مدت زمانى است كه اثر در قلمرو مالكيت خصوصى قرار دارد مات و

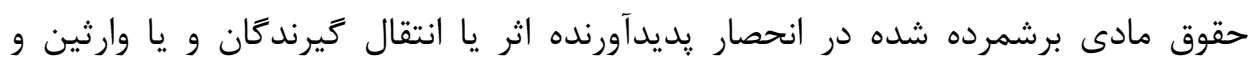

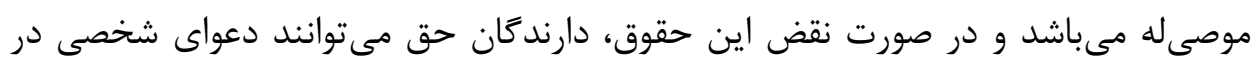

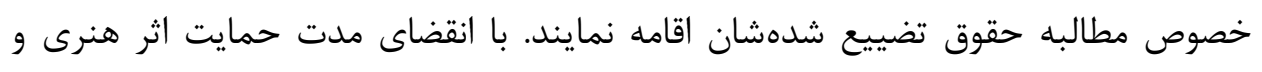

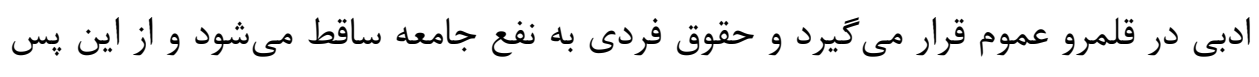

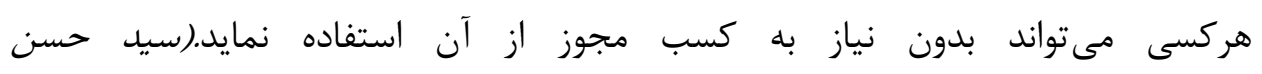

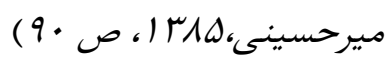


براساس بند ( ) ماده V كنوانسيون برن، مدت حمايت از اثر، طول حيات يديدآورنده به

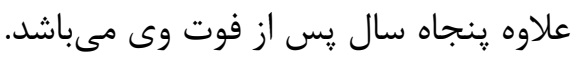

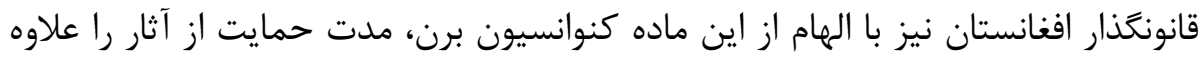

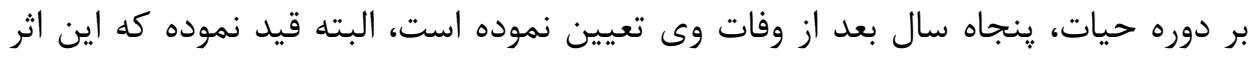
بايد طبع و نشر كرديده باشد. بند اول ماده شانزدهم قانون حمايت از حقوق مؤلف، مصنف،

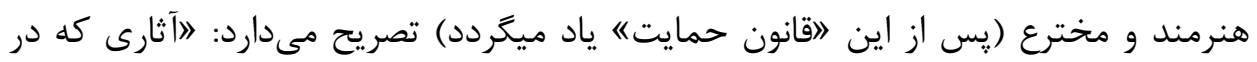

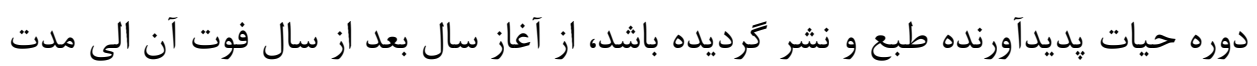

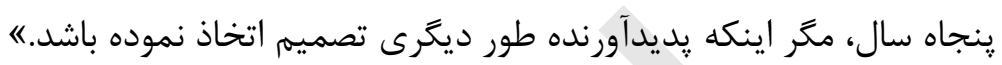

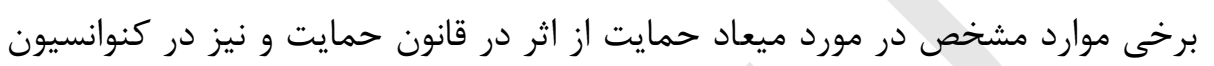
برن ذكر شده است كه به آنها اشاره مئنماييم:

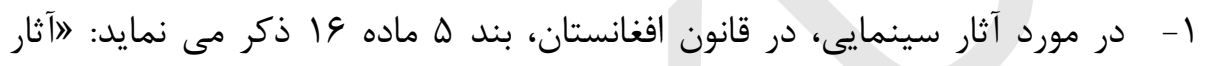

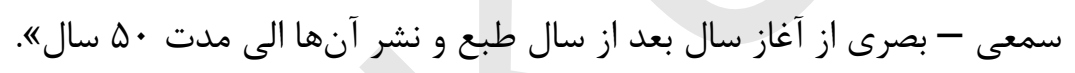

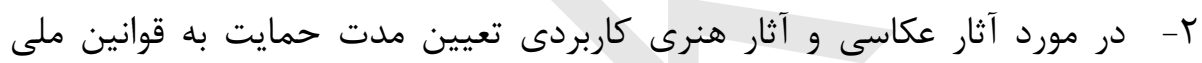

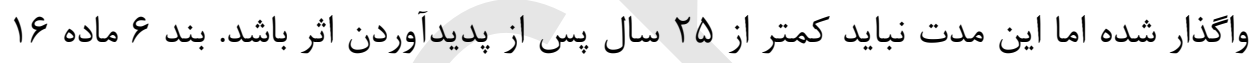

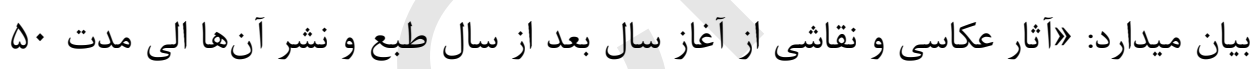

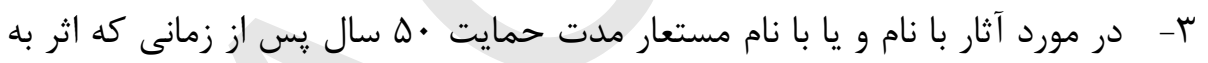

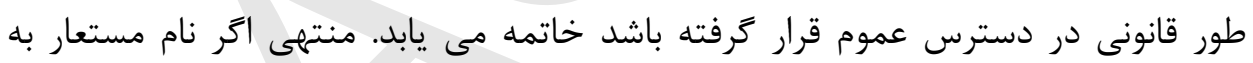
سال《.

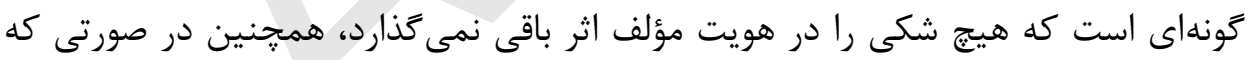

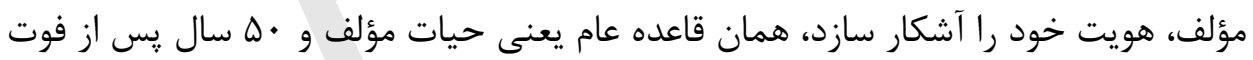

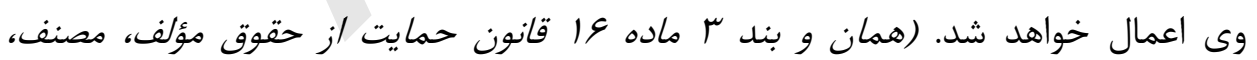

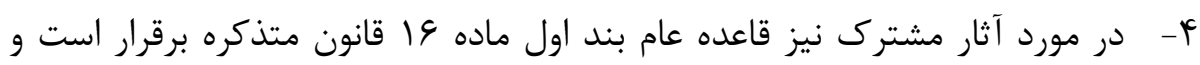

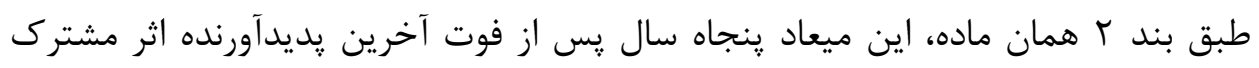
خواهد بود. موافقتنامه جنبههاى تجارتى حقوق مالكيت معنوى، در ماده با إ خويش، مدت حمايت

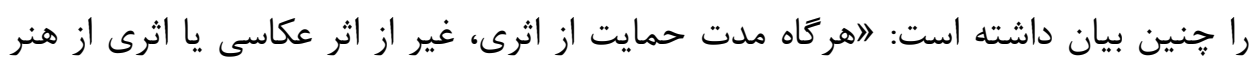




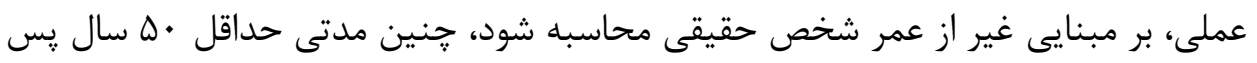

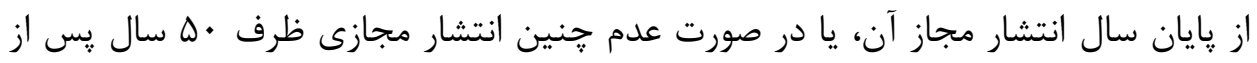

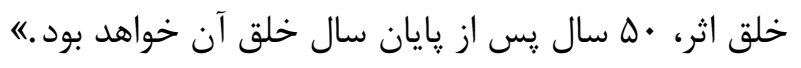

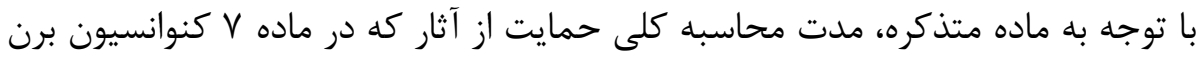

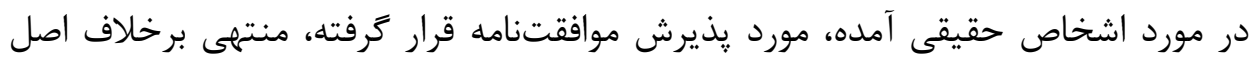

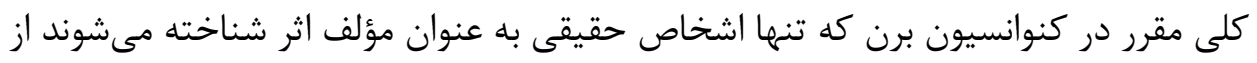

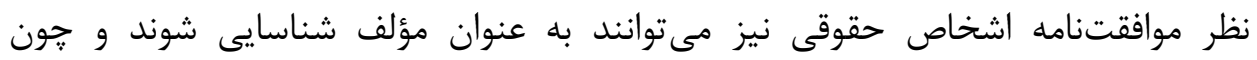

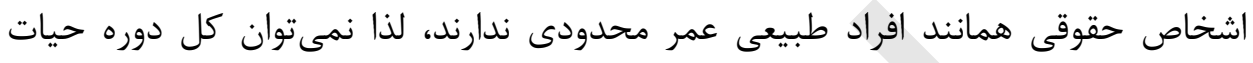

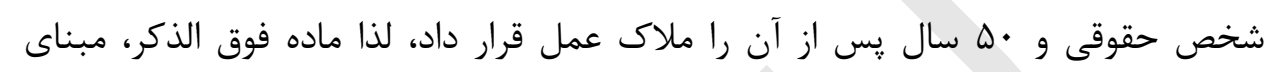

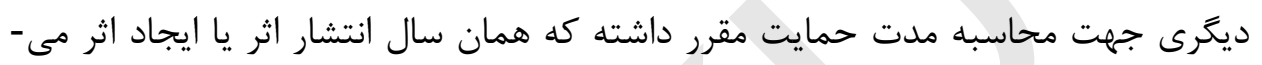

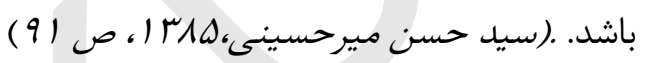

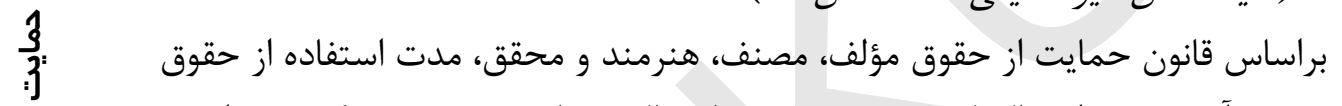

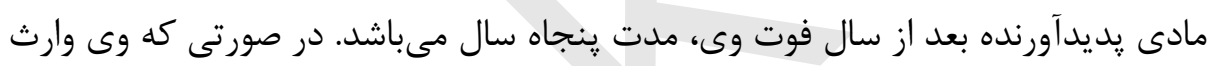

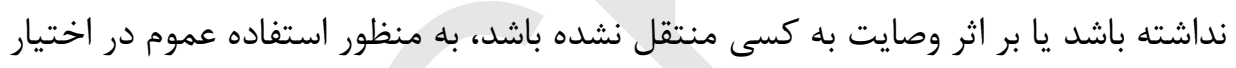

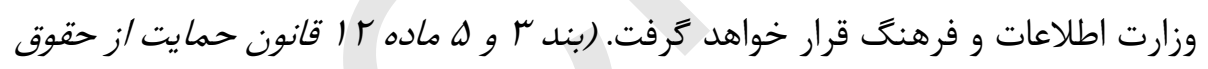
مؤلف، مصنف، هنرمنل و محقق)

\section{كَفتار دوم: حالات استفاده از اثر بدون نياز به جواز}

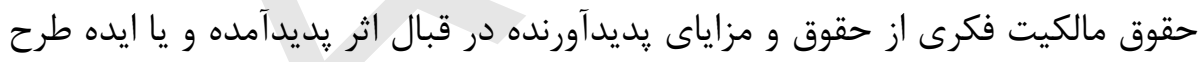

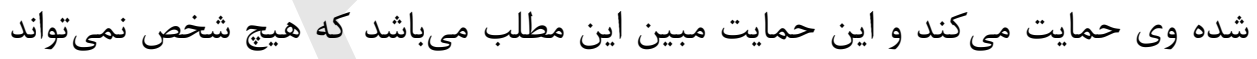

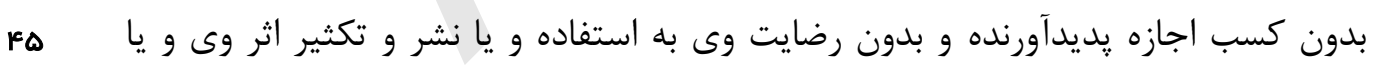

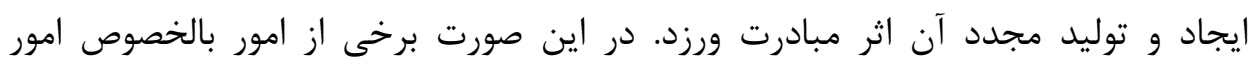

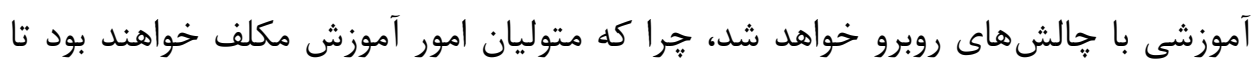

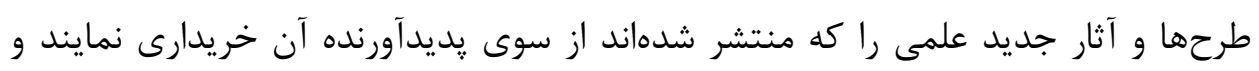

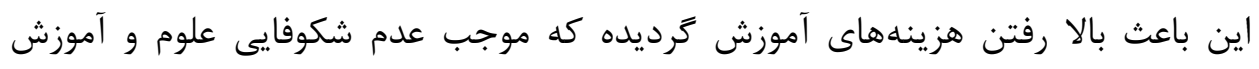

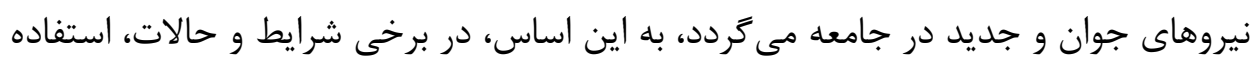

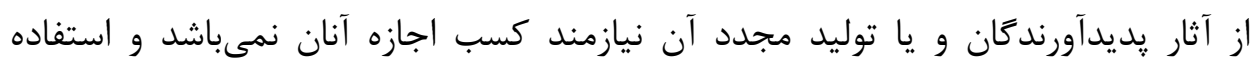


كننده مى تواند از آن استفاده لازم را ببرد، در اين كفتار به اين شرايط و حالات اشاره مى كردد:

قانونكذار افغانستان در ماده سى و نهم و جهلم قانون حمايت به مواردى يرداخته است

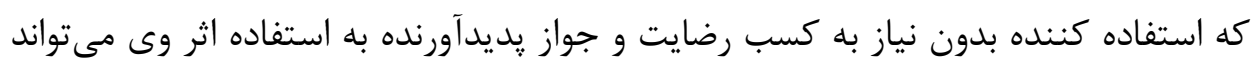

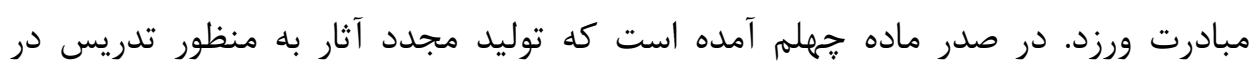

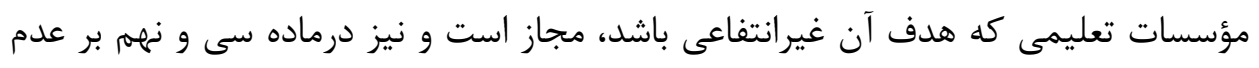

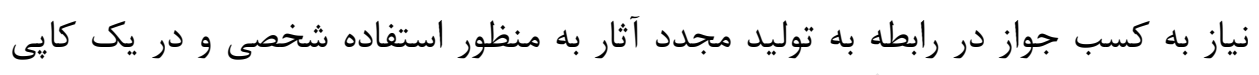

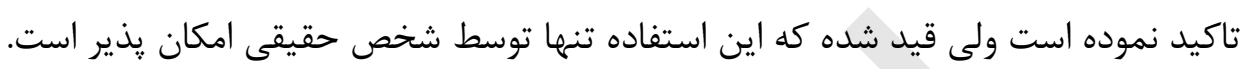
ماده سى و نهم بيان مى دارد:

")

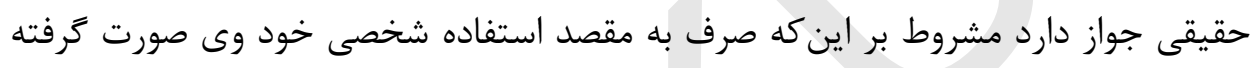
باشد....

در اين ماده به روشنى بيان نموده كه هر شخص حقيقى مى تواند از اثر تنها يك كايى را

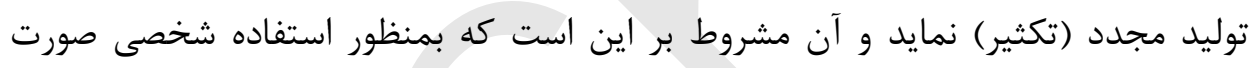

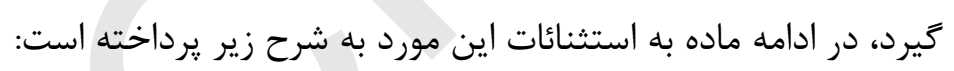

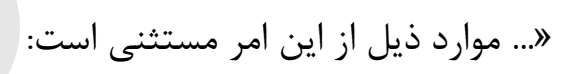
1- توليد مجدد اثر معمارى به شكل عمارت يا ساختمان ديخر.

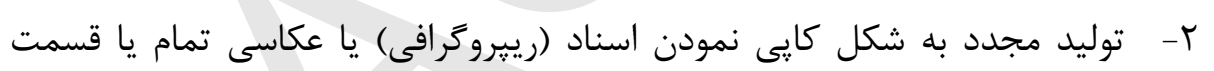

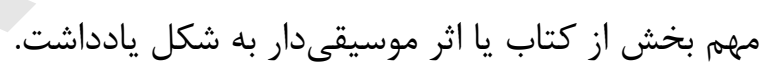

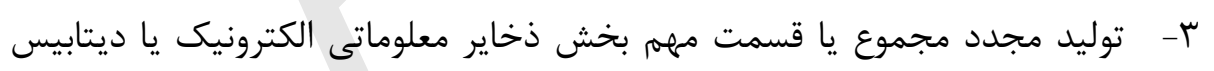

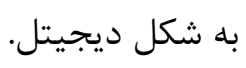

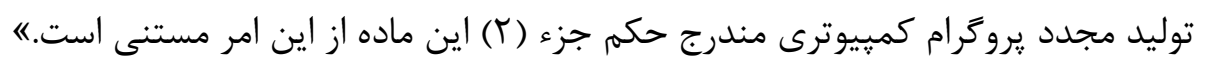

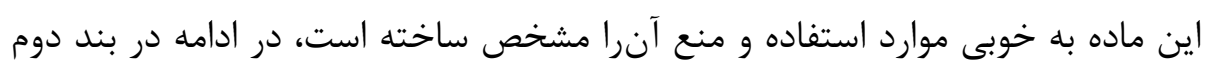

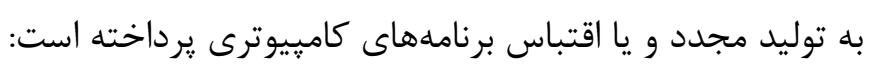

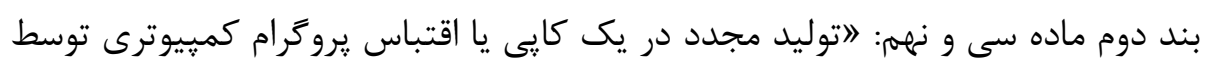

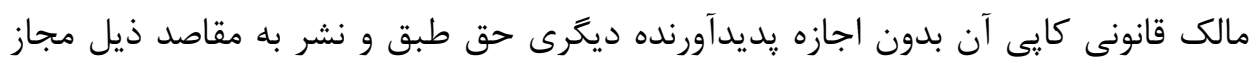
مىباشد: 


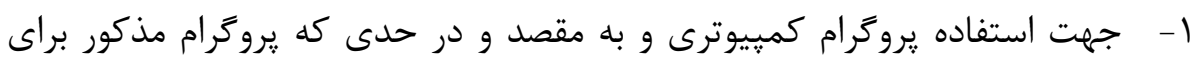

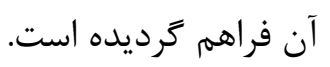

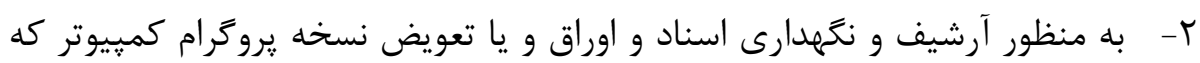

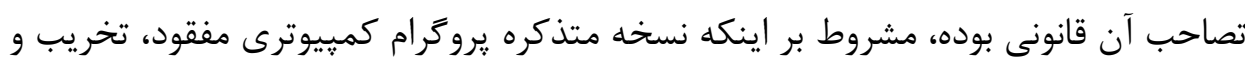

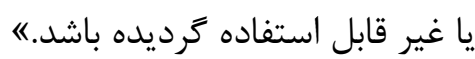

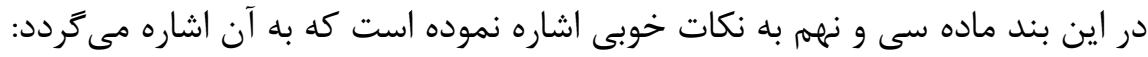

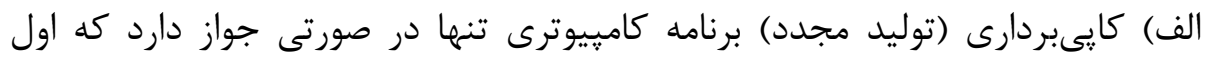

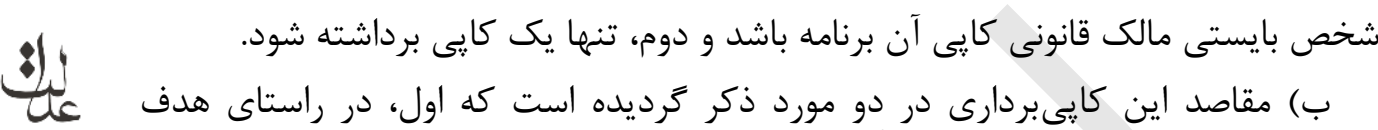

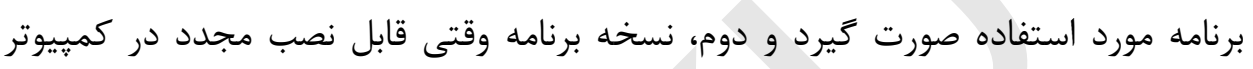

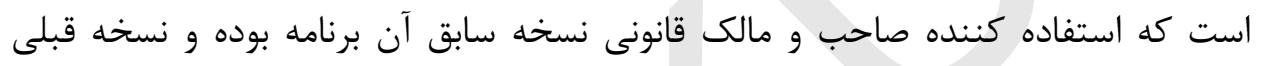

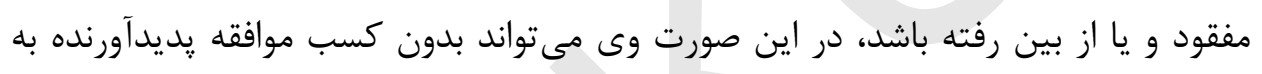

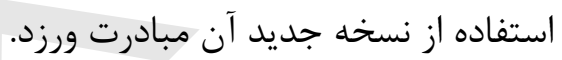

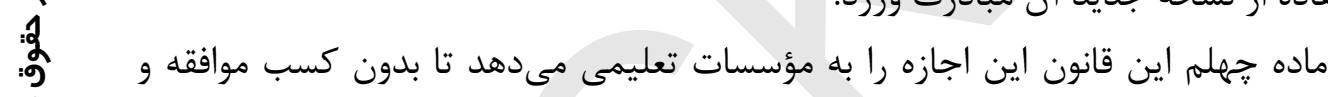

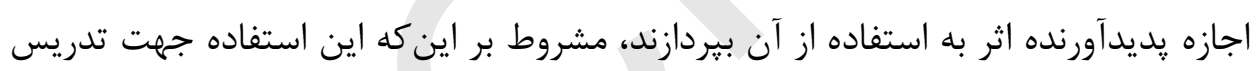

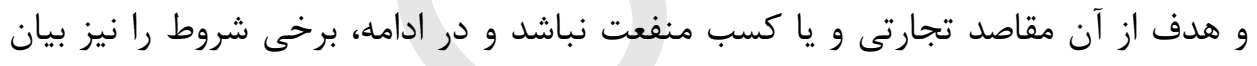
داشته است.

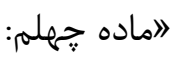

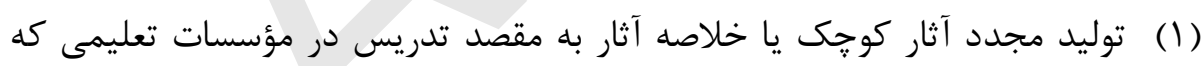

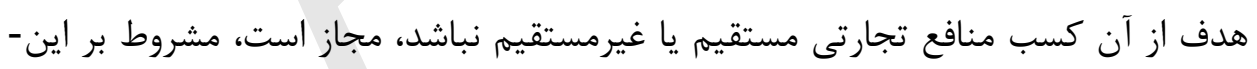
FV 1 - عمليه توليد مجدد به شكل يك مرتبهاى بوده و در صورت تكرار، موارد آن بايد جداعانه و از هم مجزا باشد.

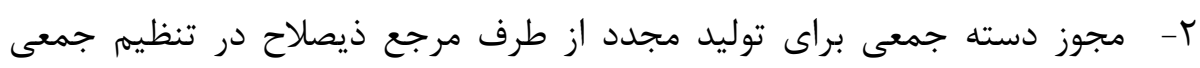

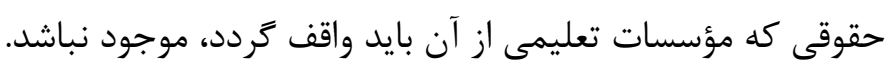

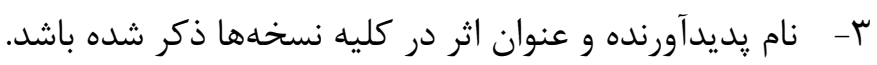


(T) (T)

1 - در صورتى كه متضمن منفعت مستقيم يا غيرمستقيم مادى نباشد.

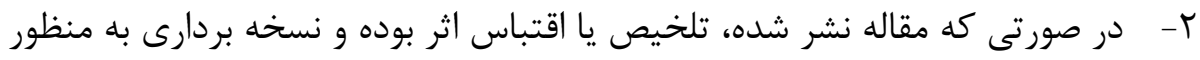

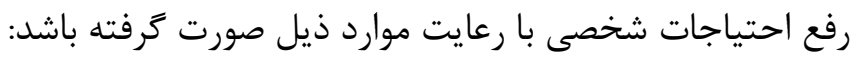

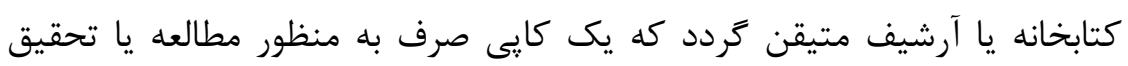

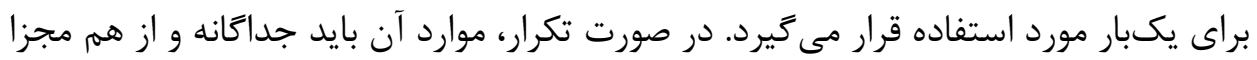

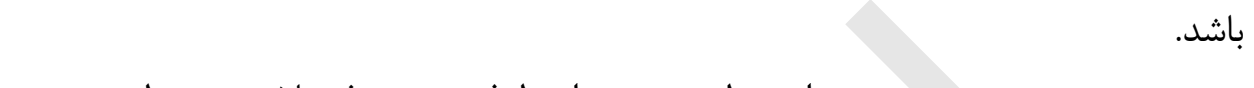
مجوز دسته جمعى براى توليد مجدد از طرف مرجع ذيصلاح در تنظيم جمعى آنى

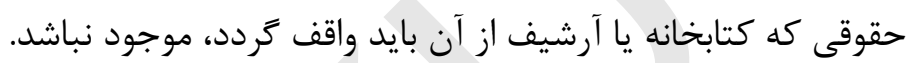

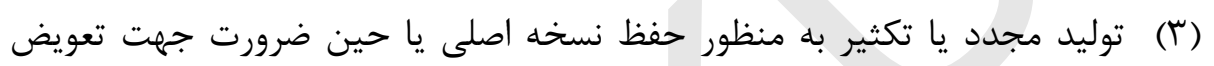

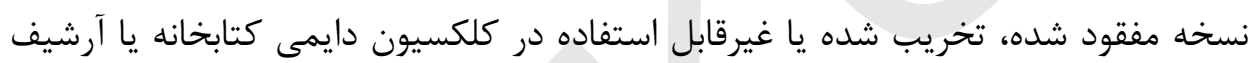
مشابه ديكر تحت شرايط ذيل جواز دارد:

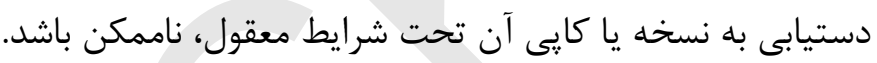

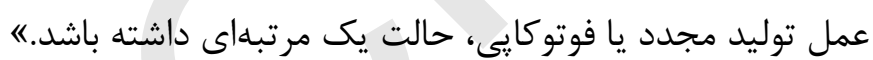

\section{كفتار سوم: ثبت آثار}

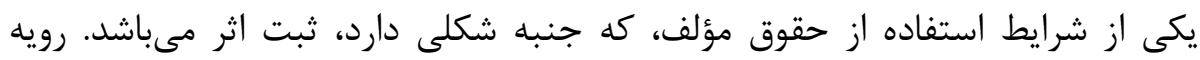

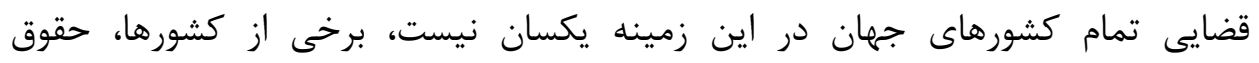

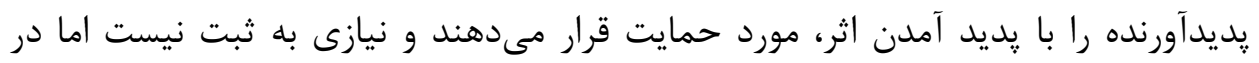

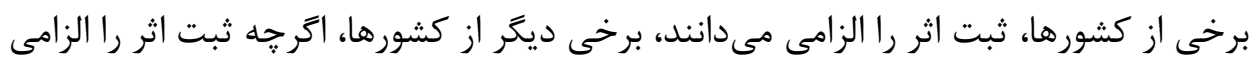

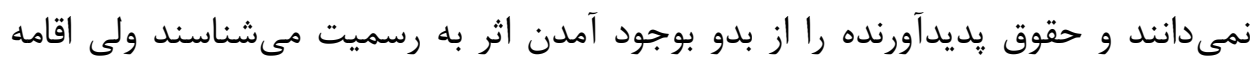


دعوا در زمينه را مستلزم ثبت اثر مىدانند، به اين ترتيب، شاكى بايستى ابتدا اثر خود را

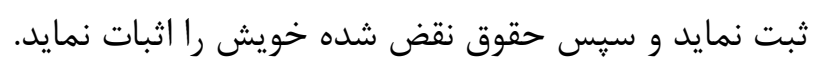

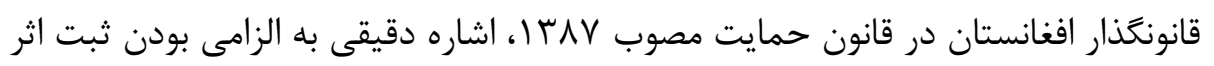

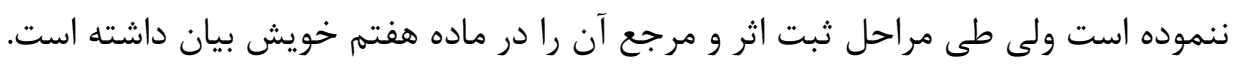

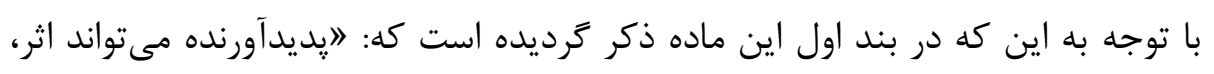

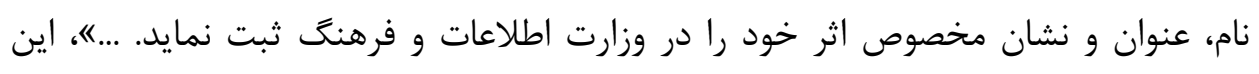

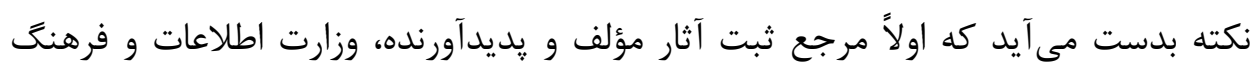

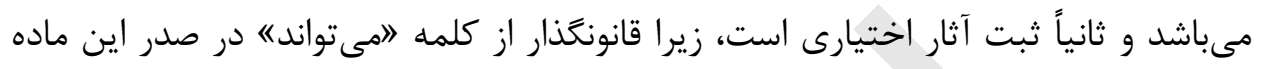

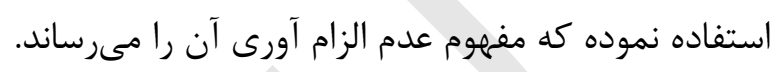

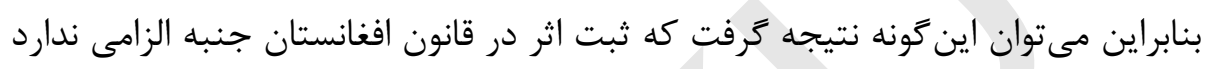

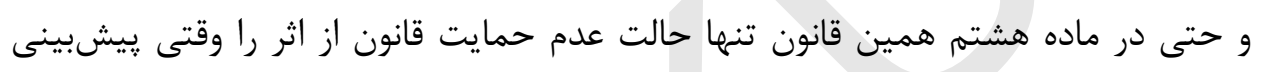

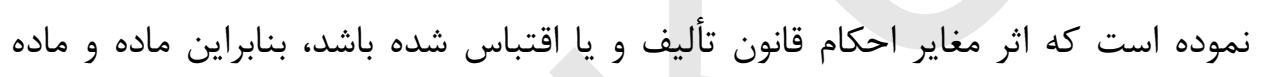

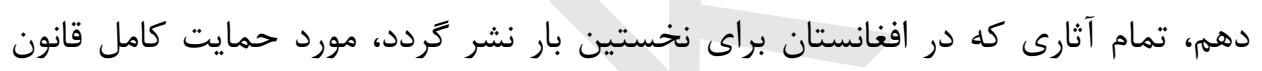

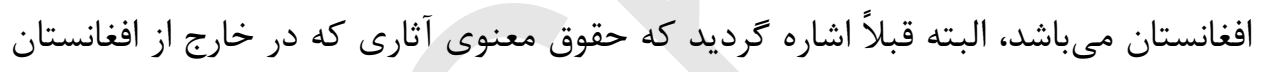

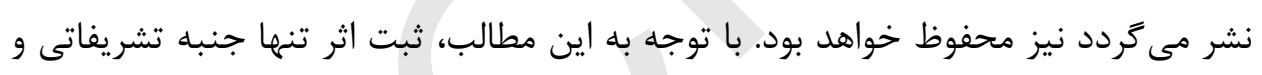

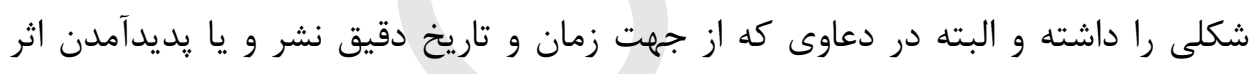

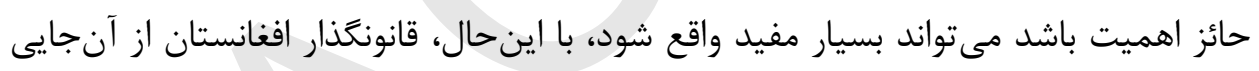

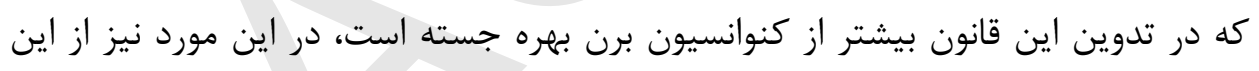

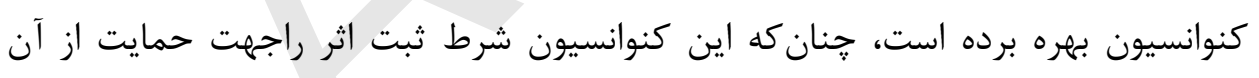

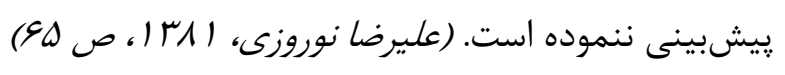

\section{مبحث سوم: نقض حقوق مالكيت ادبى و هنرى}

فصل ششم قانون حمايت از حقوق مولف، مصنف، هنوف مالديت ادبى ومندى و محقق (كايى رايت)، تحت

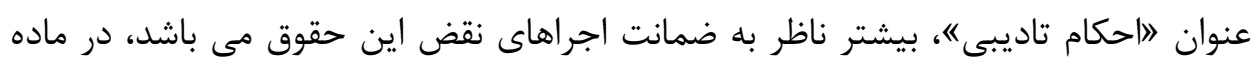

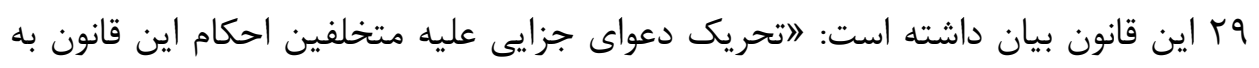

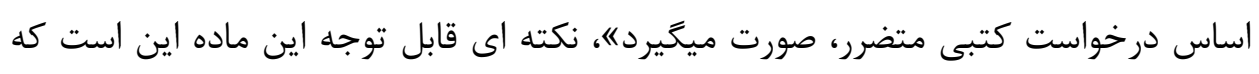

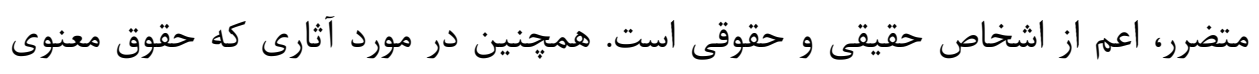




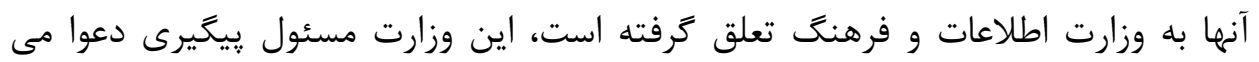

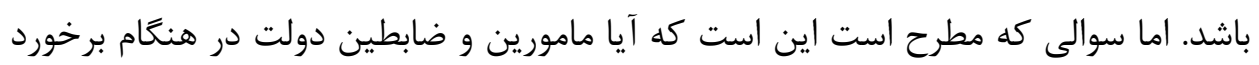

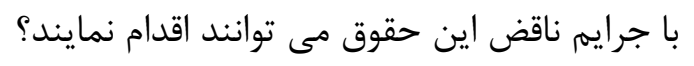

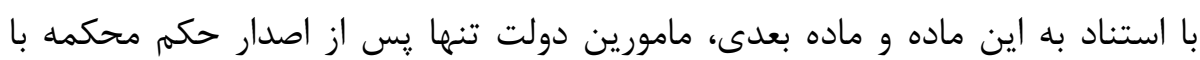

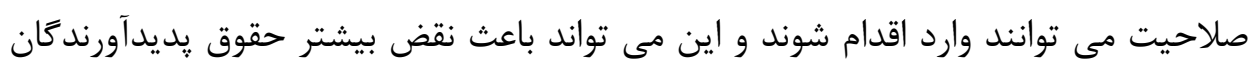

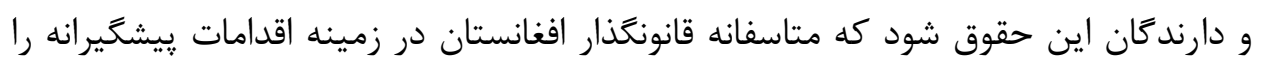

$$
\text { در نظر نكرفته است. }
$$

بند اول ماده سى ام اشخاص واجد شرايط طرح دعواى حقوقى ران ران اظظر به بديديدآورنده

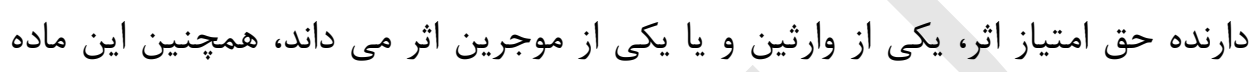

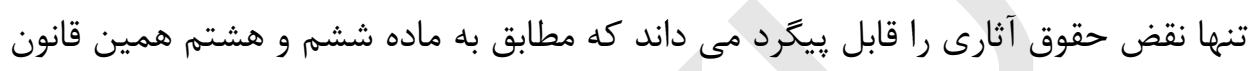

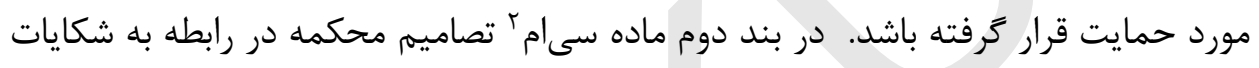

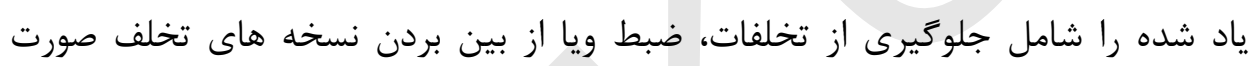

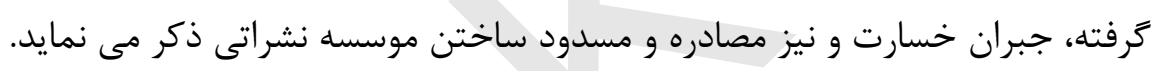

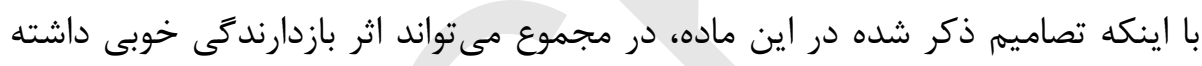

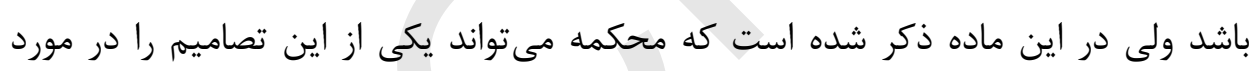

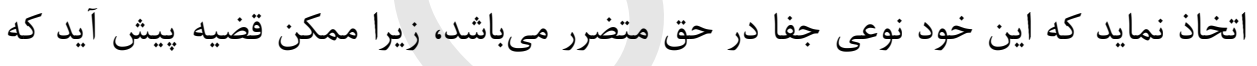

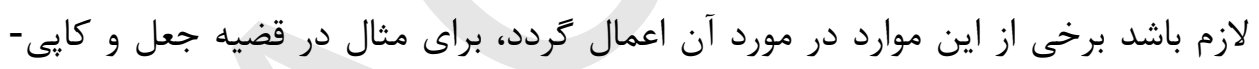


بردارى غير قانونى از يك اثر هنرى، علاوه بر اينكه ضرر اقتصادى به مؤسسه سازنده يا

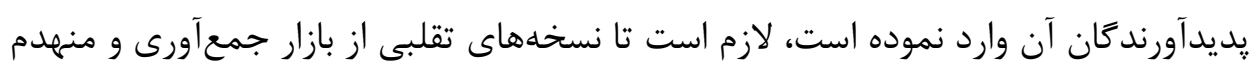

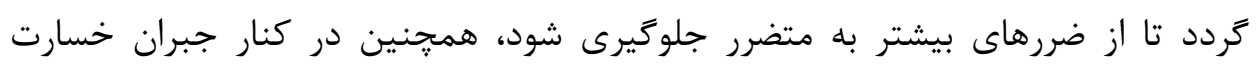

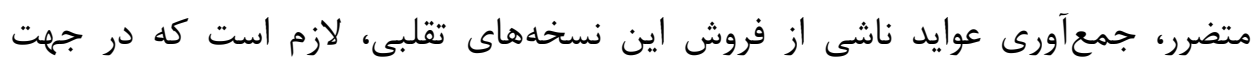

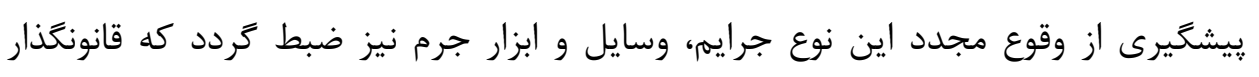

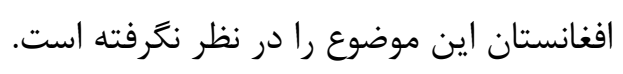

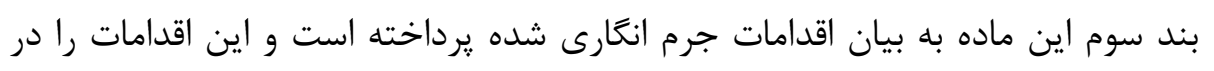
سه مورد بيان داشته است:

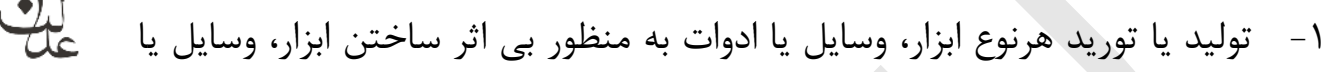

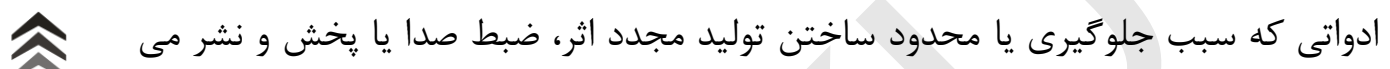
كردد يا اينكه هدف آن تضعيف كيفيت اثر باشد.

3.

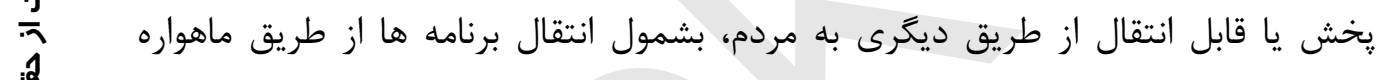

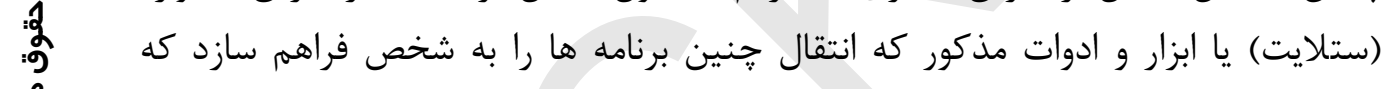
مستحق دريافت آنها نمى باشد.

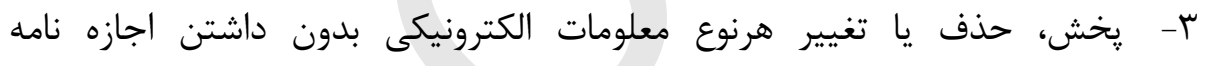
يديدآورنده آن. اين بند ماده سى ام نمى تواند كامل باشد و بيشتر ناظر بله آثار سمعى و بصرى و

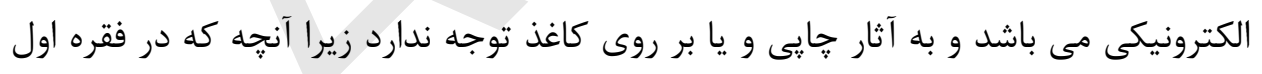

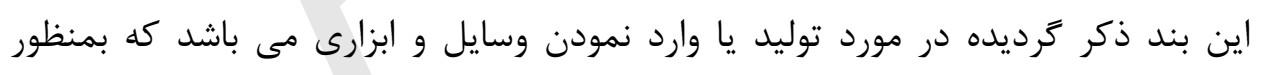

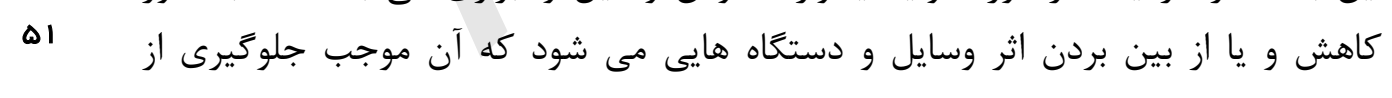

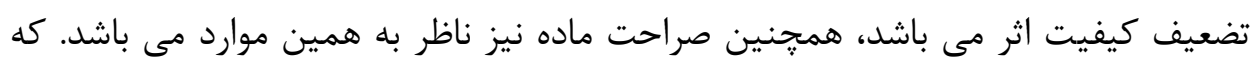

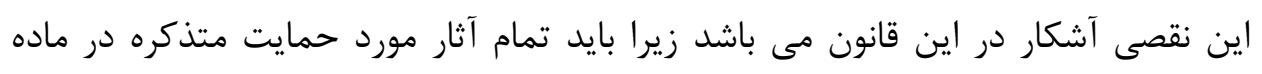
ششم را احتوا مى نمود. همجنين بيان قانون در ترتيب بند دوم و سوم اين ماده نمى تواند درست باشد، زيرا

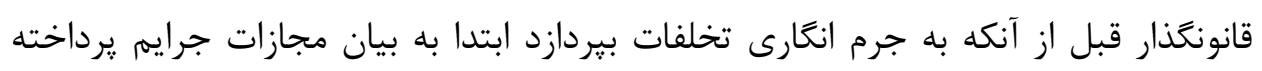

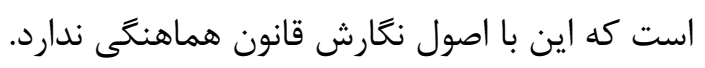


ماده سى و يكم به بيان مجازات براى اشخاص مرتكب نقض حقوق ادبى و هنرى يرداخته

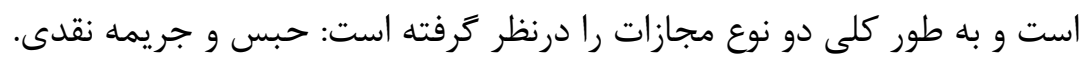

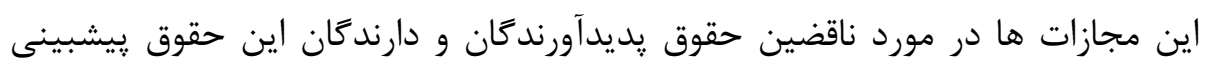
شده است و در ماده سب آن را به ناقضين حقوق جانبى نيز تعميم مى ده دهد.

\section{كفتار اول: بررسى جرايم نقض حقوق مالكيت فكرى در افغانستان:}

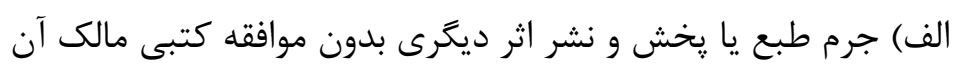

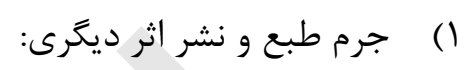

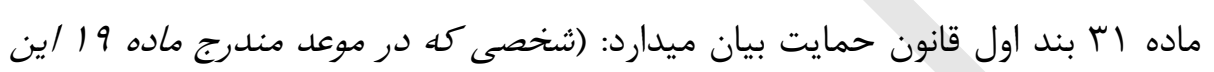

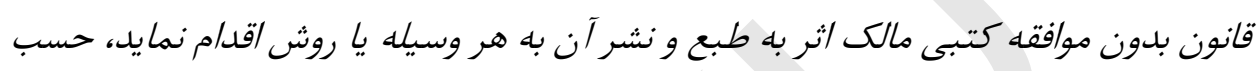

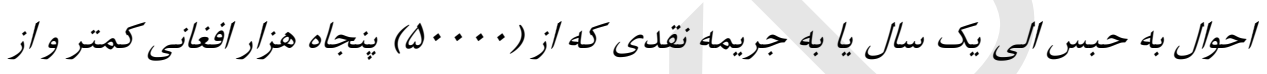

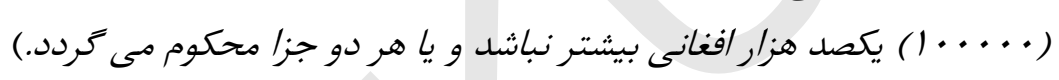

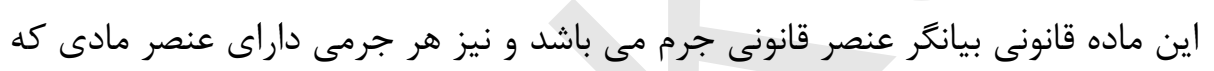

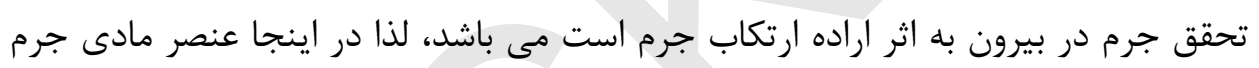

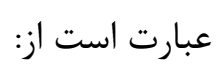

* شخصيت مرتكب: با توجه به وازه اشخصى" كه در صدر اين ماده آمده است، مجرم مى تواند شخص حقيقى و يا حقوقى باشد.

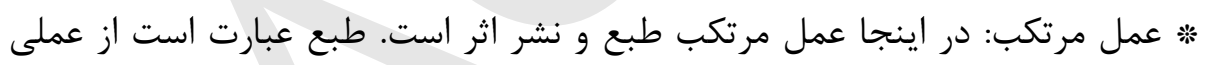

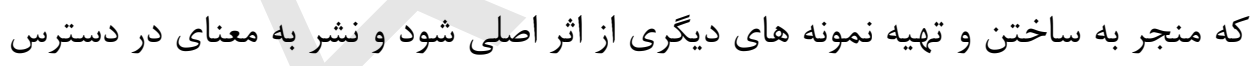

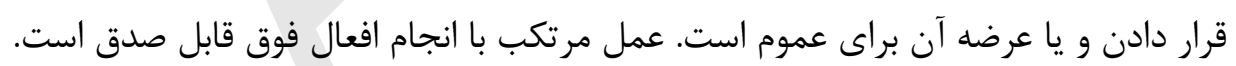

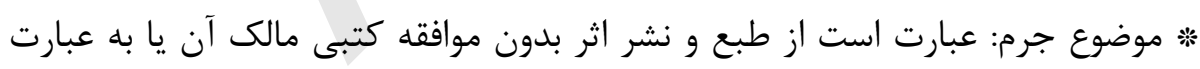

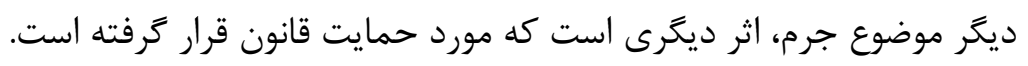

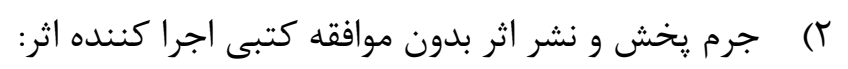

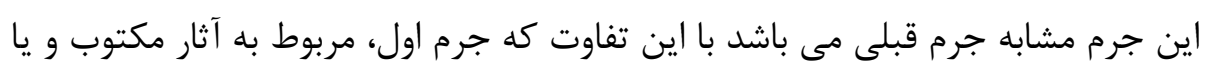

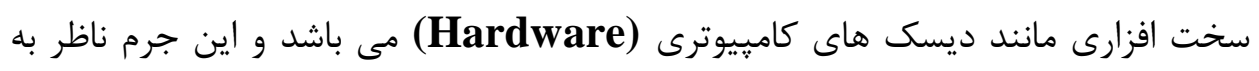

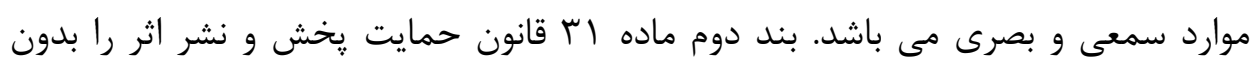

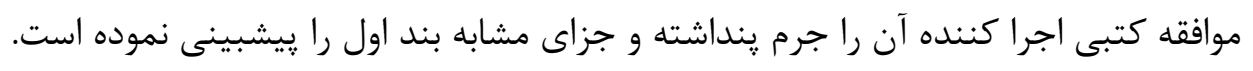




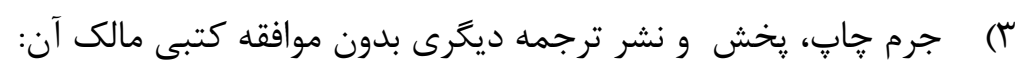

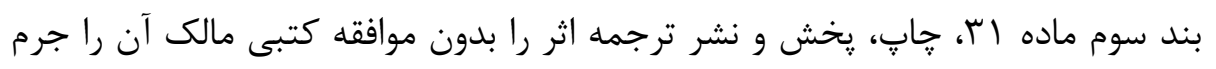

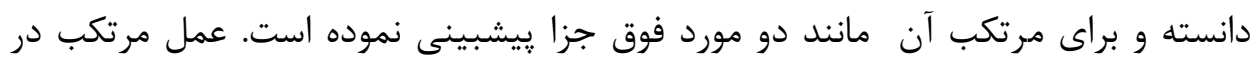

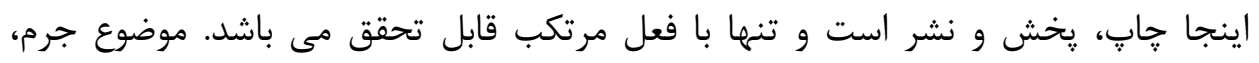

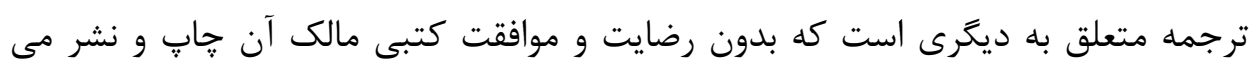

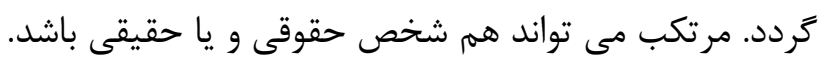

$$
\text { ب) جرم اقتباس غيرقانونى: }
$$

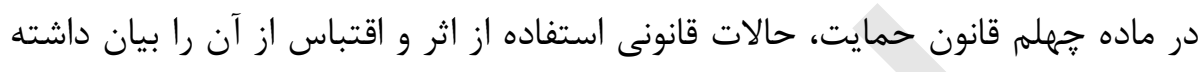

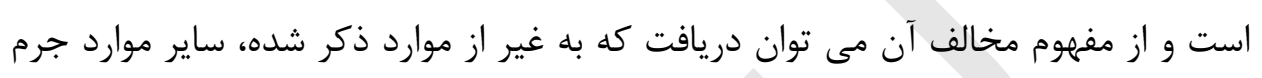
ينداشته خواهد شد.

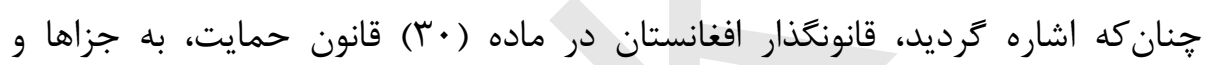

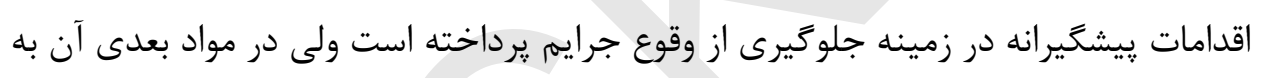

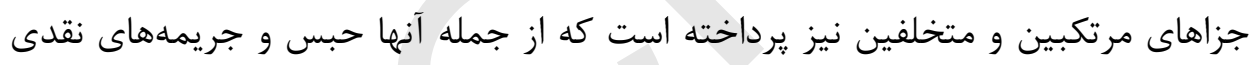
مىباشد.

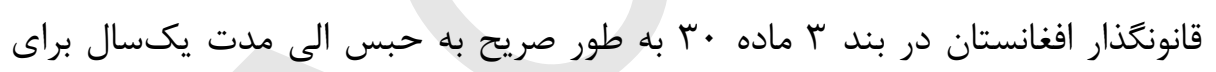

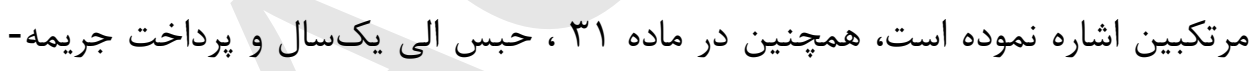

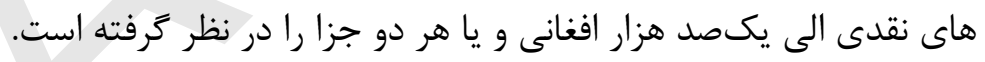

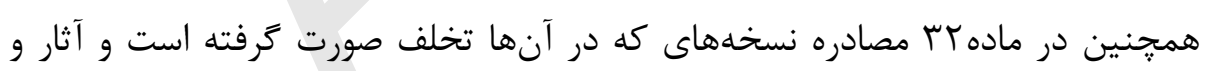
$\Delta \mu$

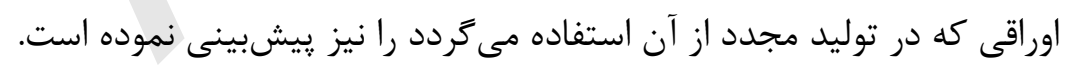

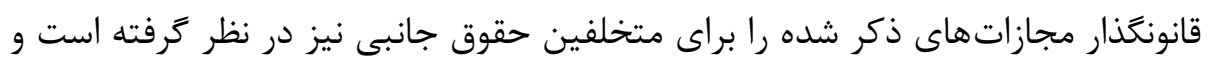

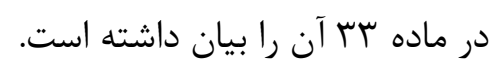

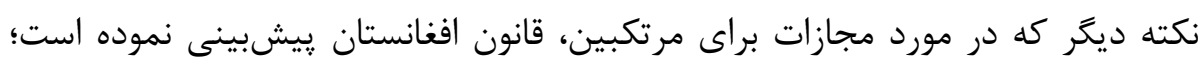

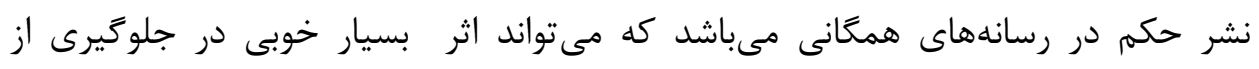

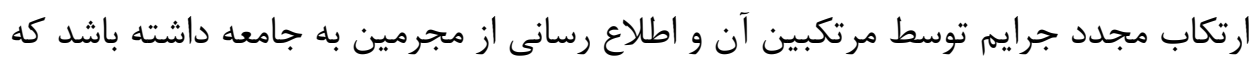

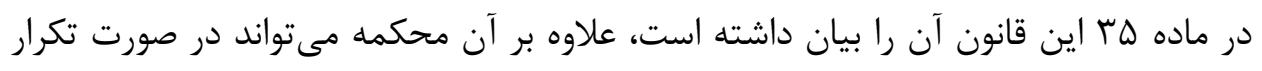


تخلف، حالت مشدده را در نظر گيرد كه آن دو برابر كردن مجازات در نظر كرفته شده در مواد اين قانون براى مرتكبين مى باشد.

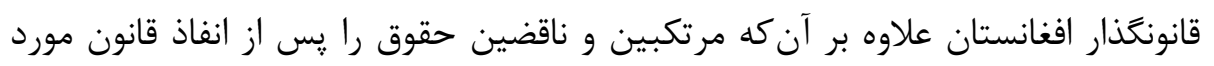

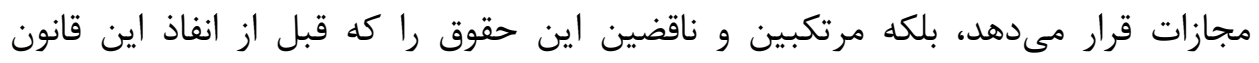

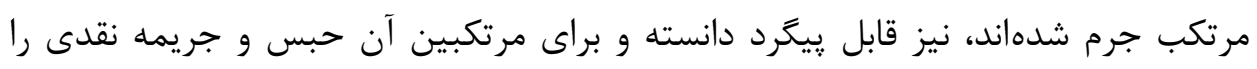
پيشبينى نموده است.

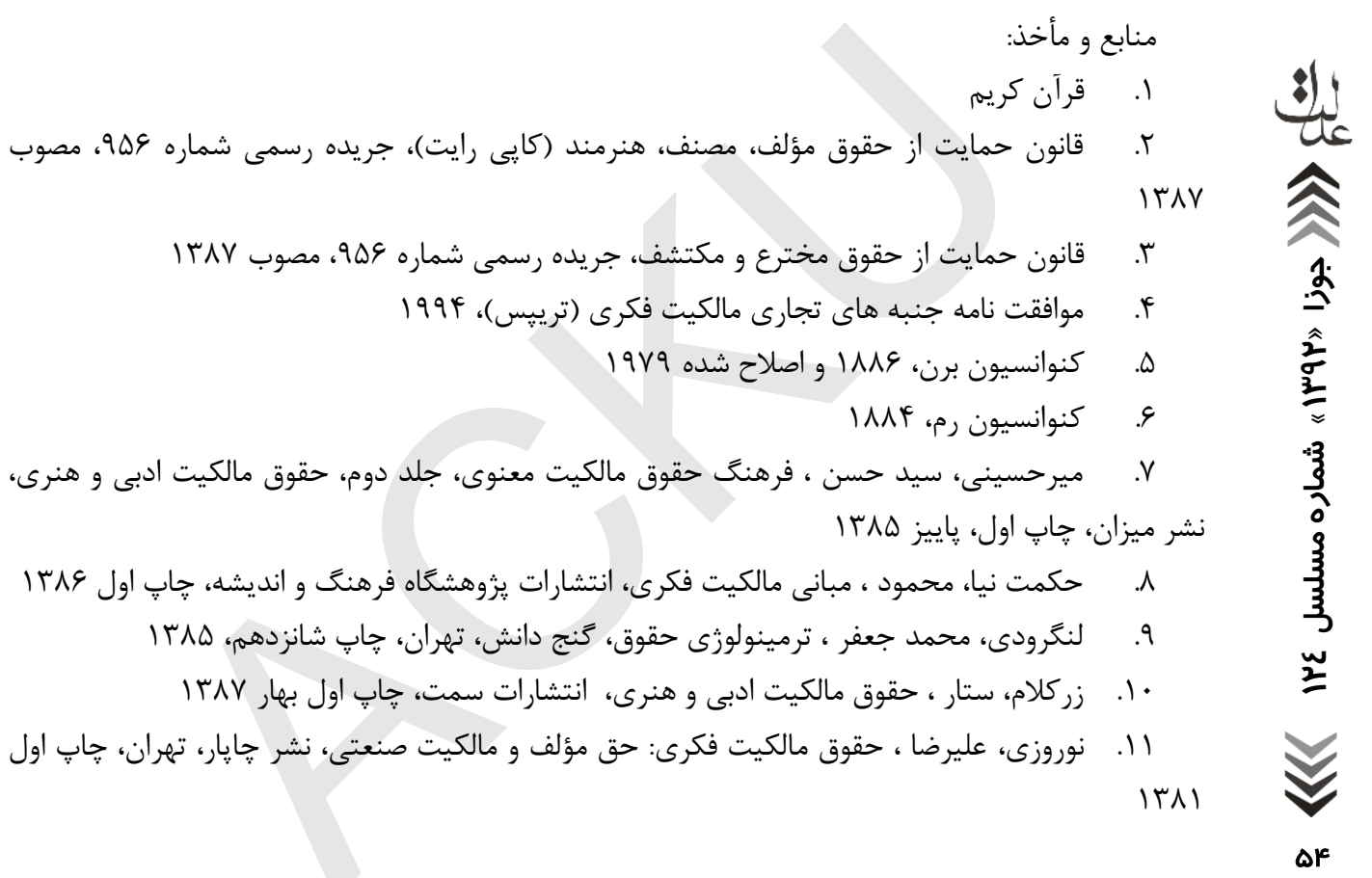




\section{نظام تأمين اجتماعى در افغانستان}

سيدمحمد هاشمى

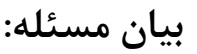

امنيت ازجمله مفاهيمى است كه در زندكى روزانه با آن سروكارمستمرداريم وباتوجه به

اينكه انسان ها درموقعيت هاى گوناگون بامنيت درگير هستند، بخونه اى مثال مثال الطمنان

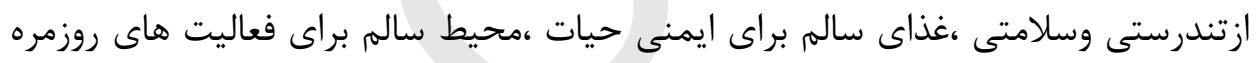

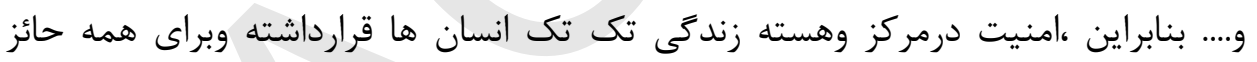
اهميت است.

در جامعه شناسى ،امنيت تنها به مفهوم توان مقابله ومبارزه باخطرات وتهديدات نيست

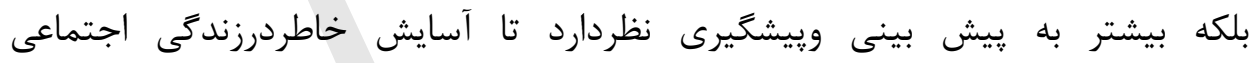

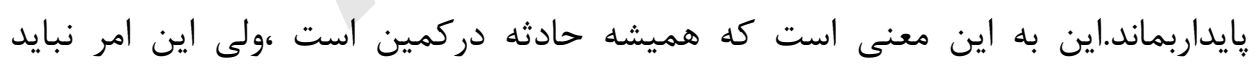

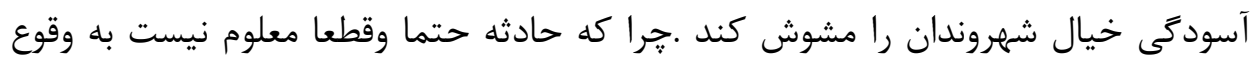

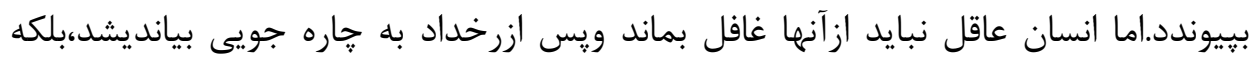

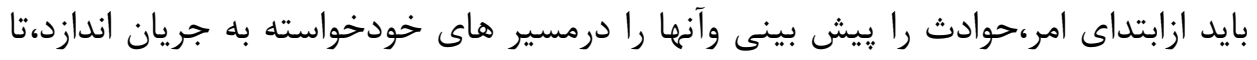
آرامش ماندگارشود.

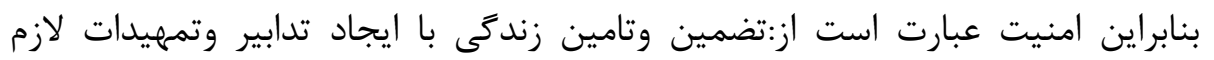

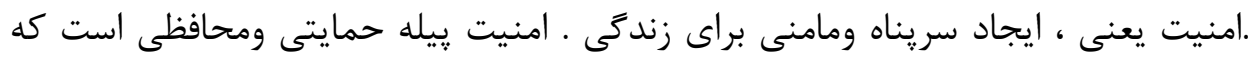


موجب آسودگى خيال وخاطر جمعى مى شود.امنيت ،ضمانت زندگى درآسايش است(نويد

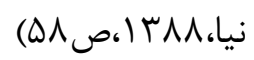

ازديد مكاتب جامعه شناسى جون :مكاتب توسعه ایى ماركسيسم وساختاركرايان ،نظم

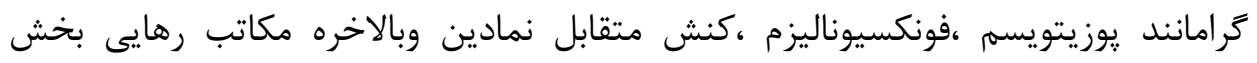

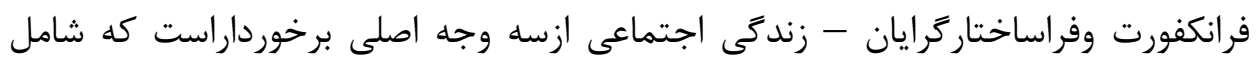

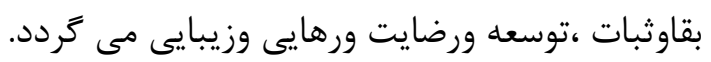

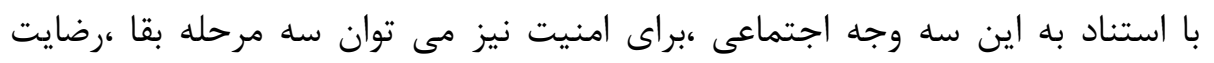

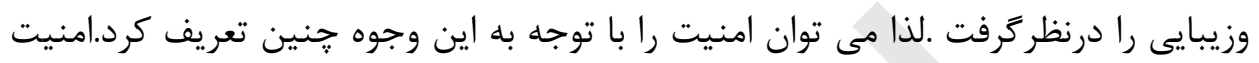

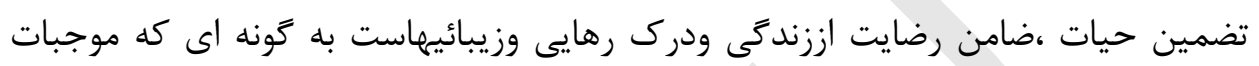

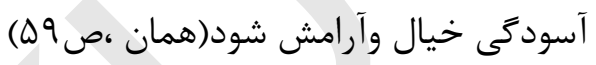

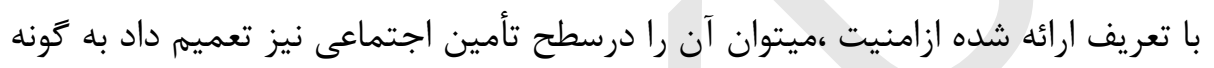

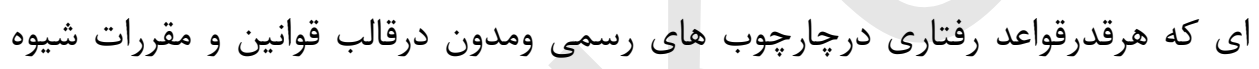

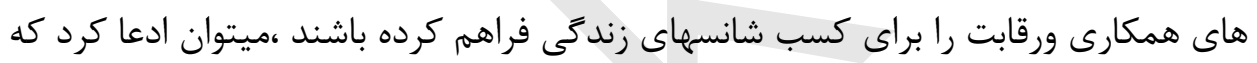

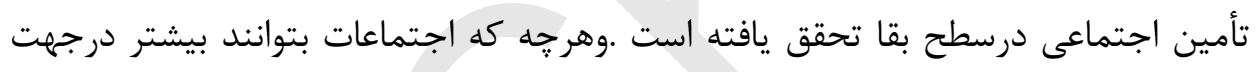

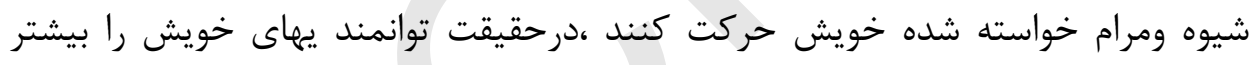

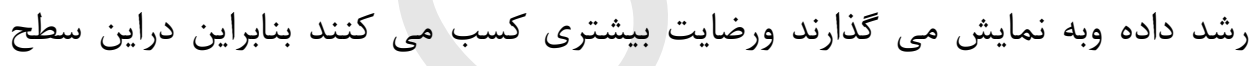

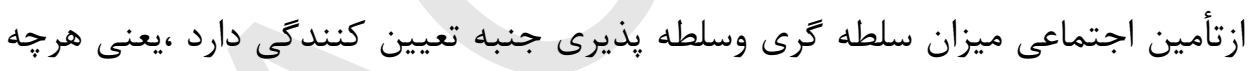

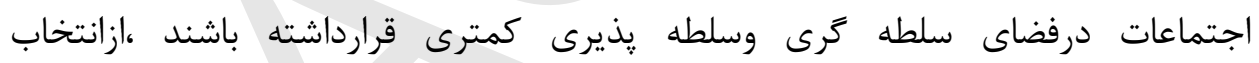

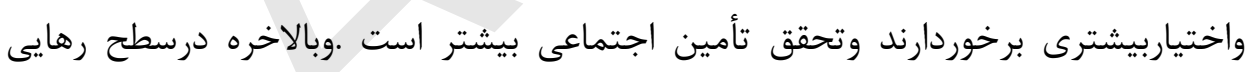

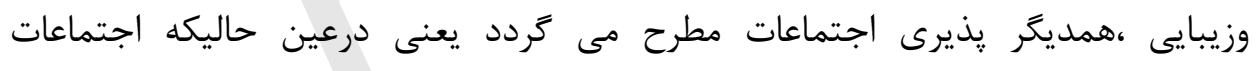

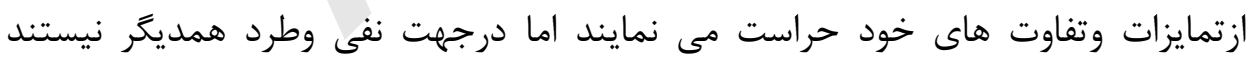

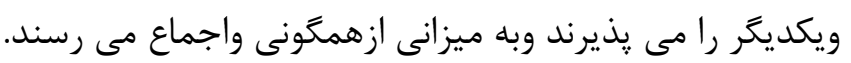

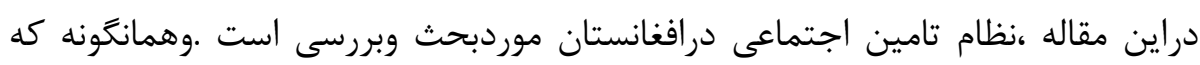

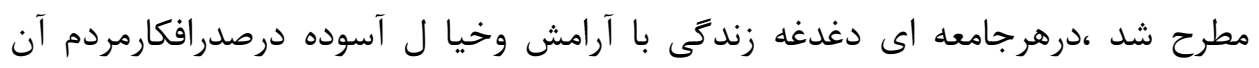

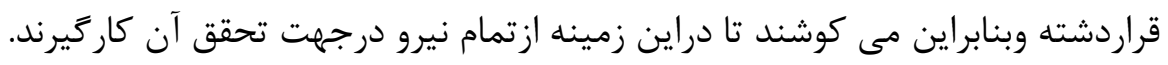

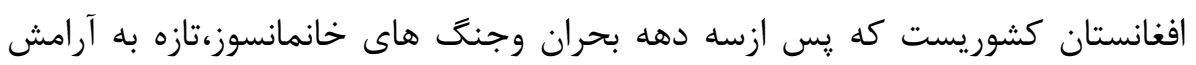

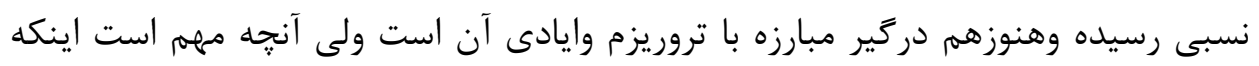


دراين دوره بايد با مديريت سالم ،همه اين مرارت ها ومشكلات را بشت سركّاشاشته وبراى

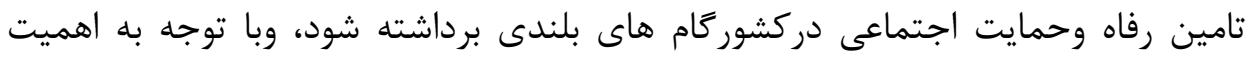

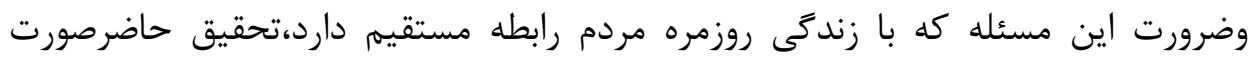

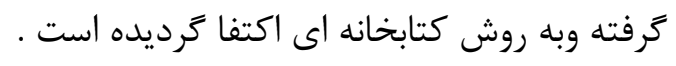

دراين تحقيق ،جامعه موردهدف ،كشورافغانستان است وهدف تحقيق ،نظام تامين اجتماعى با رويكرد جامعه شناسى توسعه ميباشد.

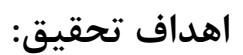

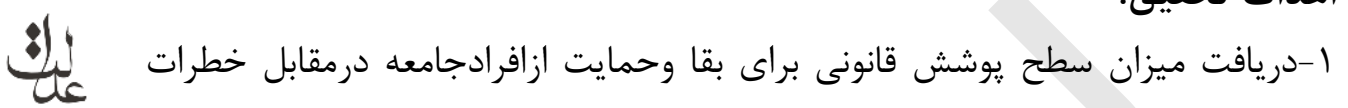

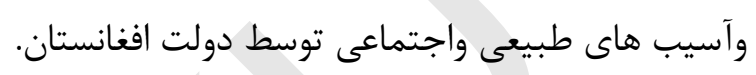

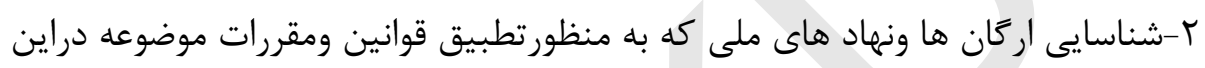
خصوص انجام وظيفه مى نمايند.

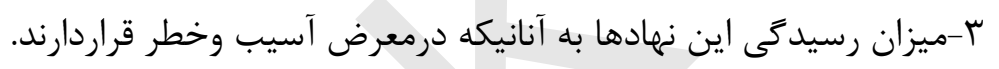

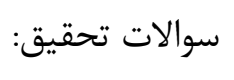
ا-آيا قوانين ومقررات وضع شده براى ارائه خدمات به مردمان آسيب يذير كافى ووافى به نظر ميرسد قبل ازيرداختن به تامين اجتماعى ويا حمايت اجتماعى درافغانستان

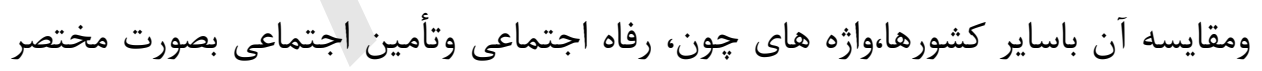
تشريح كردند.

\section{رفاه اجتماعى}

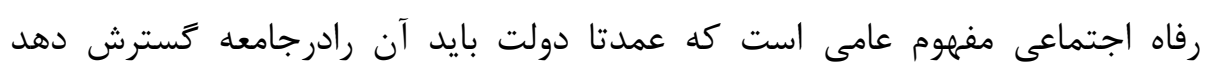

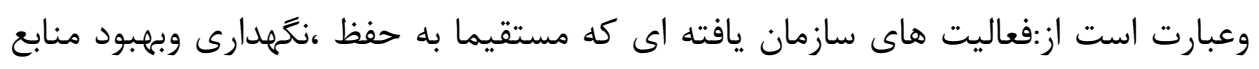

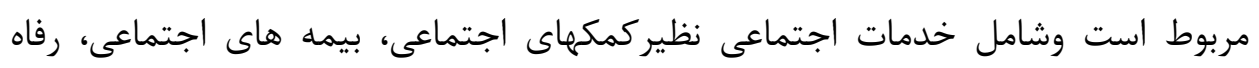


كودك، بهداشت روانى، آموزش ويرورش، تفريح وكذراندن فراغت ، حمايت ازنيروى كاروحل

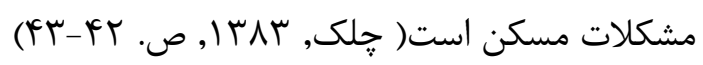

\section{تأمين اجتماعى}

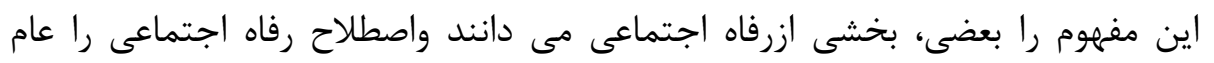

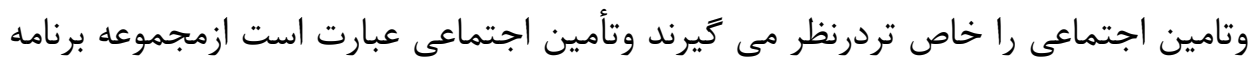

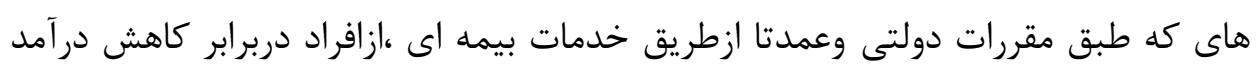

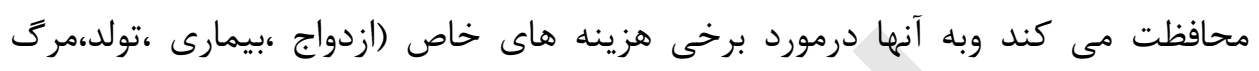

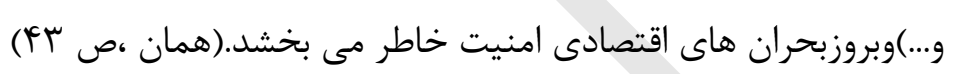

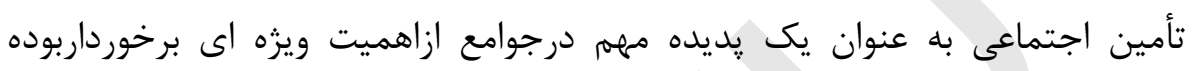

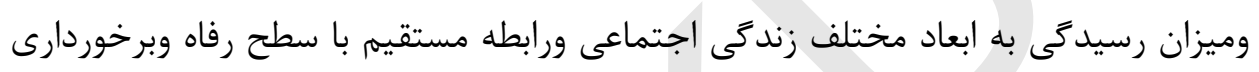

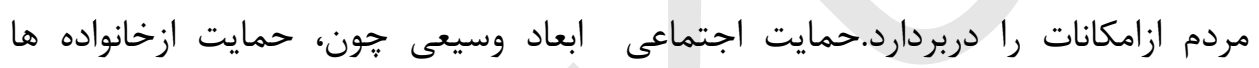

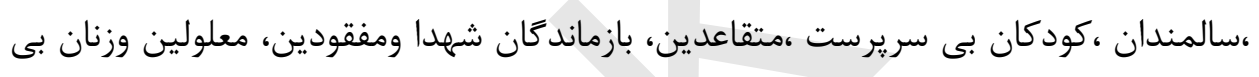

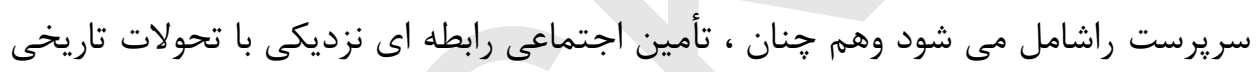

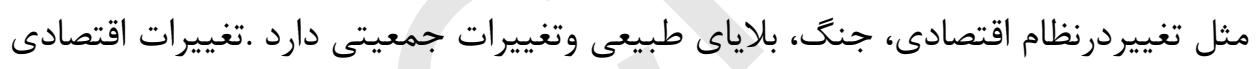

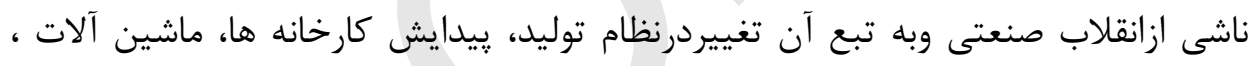

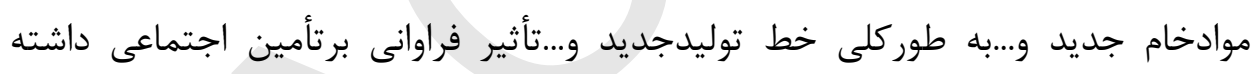

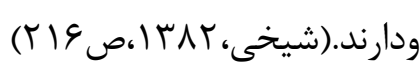

با انقلاب صنعتى، مسايل اجتماعى جديدى بوجود آمد، خانواده ها تغيير نموده ووابسته

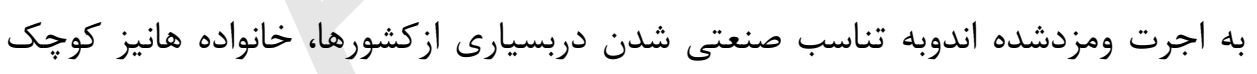

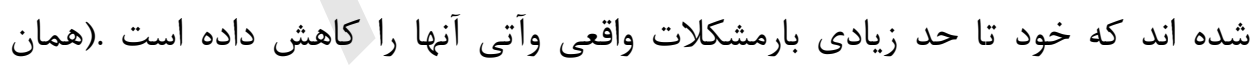

بسيارى ازدانشمندان معتقدند كه ارويا سه هديه به جهان ارزانى داشته است :انقلاب

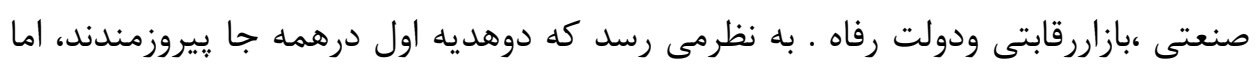
سومين موضوع موردبازنخرى وتجديد ساختارقراركرفته است. 


\section{نظام تأمين اجتماعى درافغانستان:}

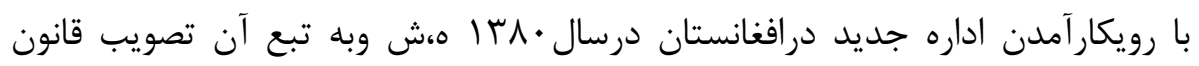

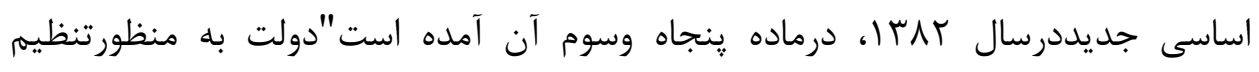

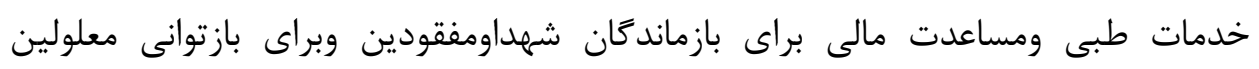

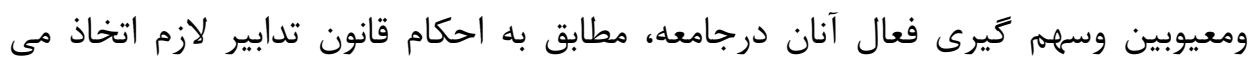

نمايد.

دولت حقوق متقاعدين را تضمين نموده ،براى كهن سالان ، زنان بى سريرست ، معيوبين

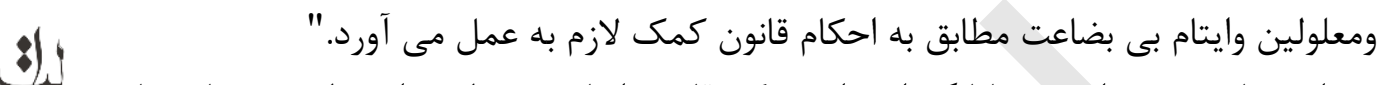

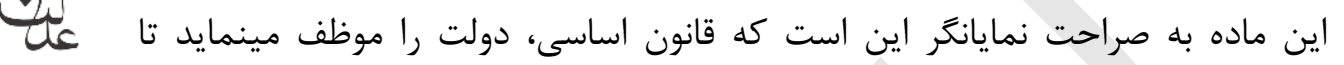

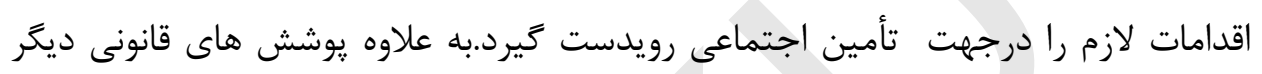

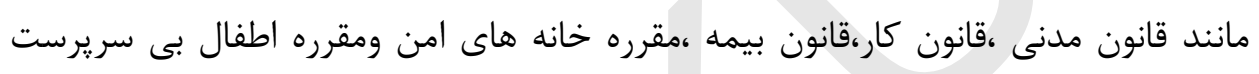

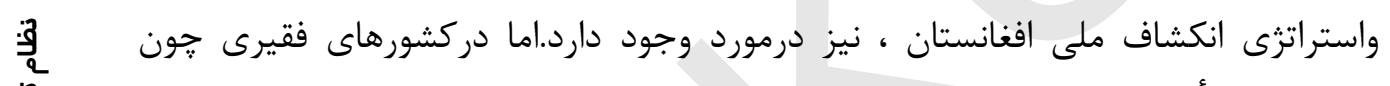

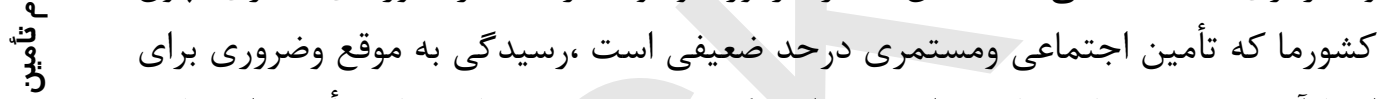

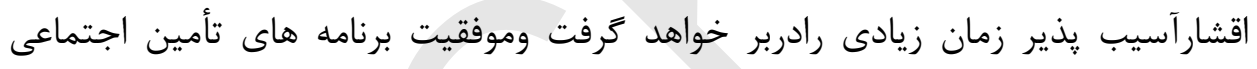

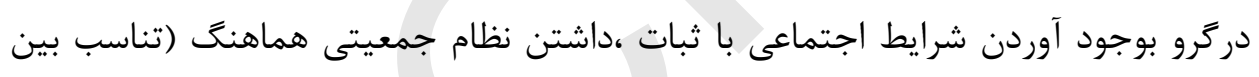

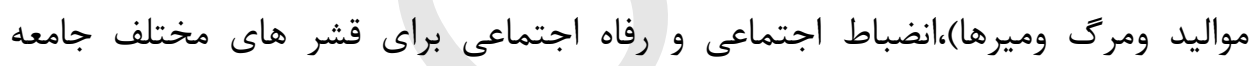

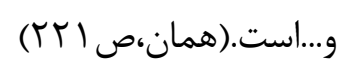

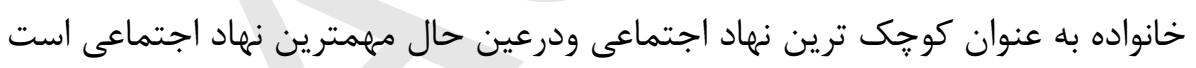
،زيرا كانون امنى همراه با صفا وصميميت است ووظيفه عمده تربيت نسل به عهد عهده اين نهاد نهاد

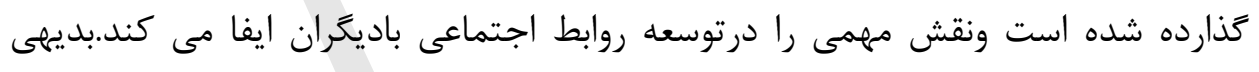

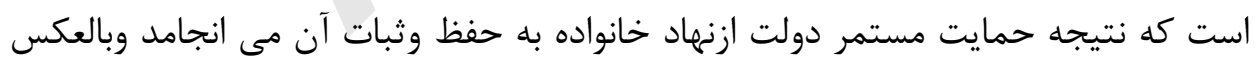

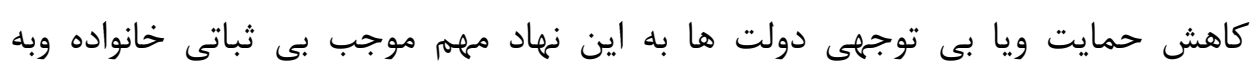

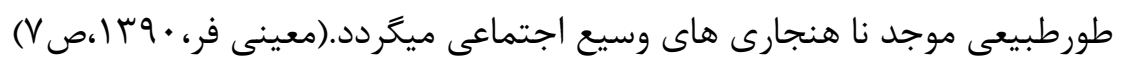

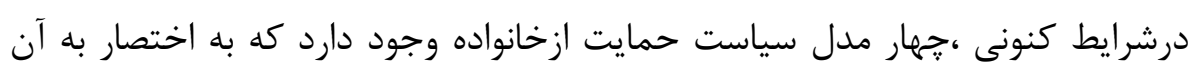
يرداخته مى شود. مودل طرفدارخانواده/طرفدارزادوولد :دراين مدل ، موضوع سطح پايين بارورى ازاهميت

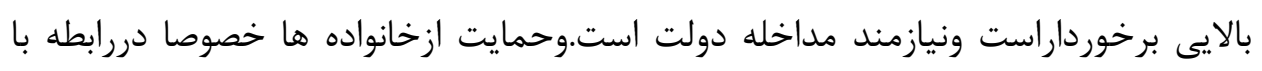


تشويق باردارى ، مسئوليت دولت تلقى مى شود.دراين مدل تاكيد زيادى بركمك هزينه هاى

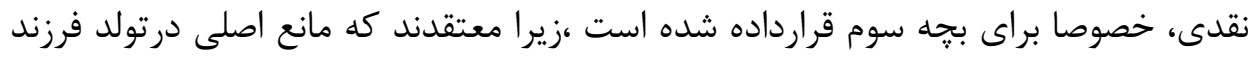

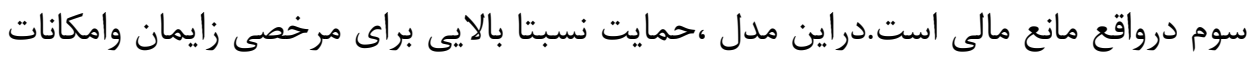

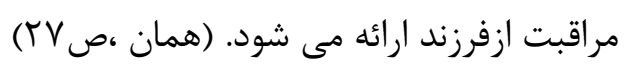

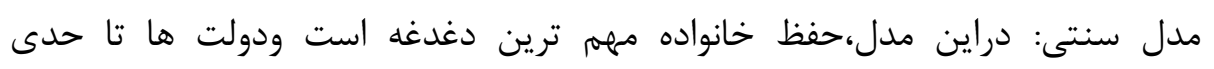

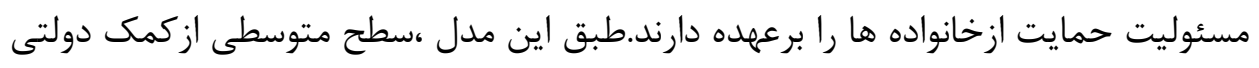

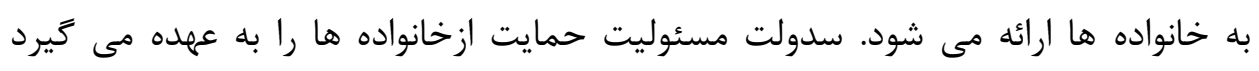

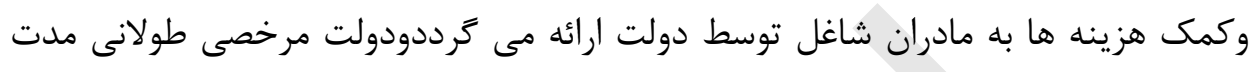

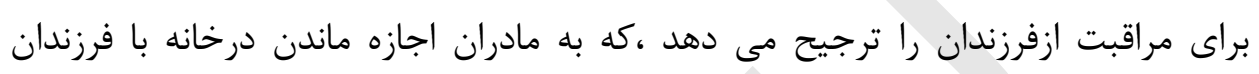

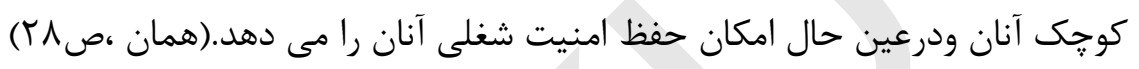

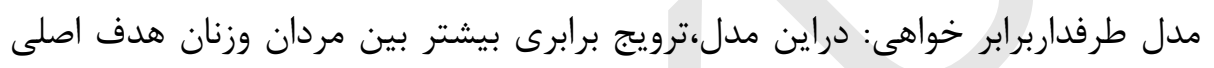

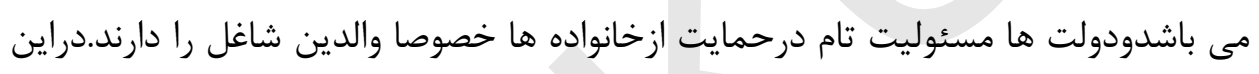

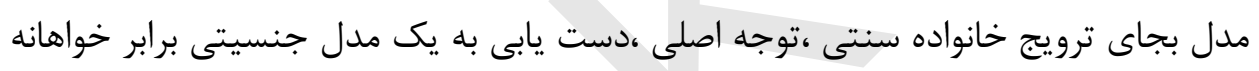

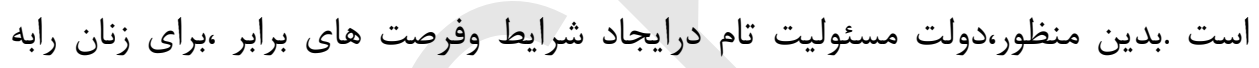

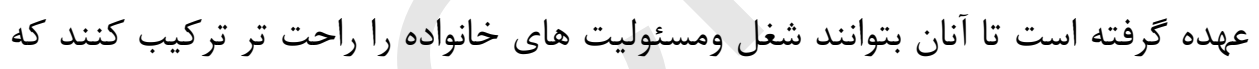

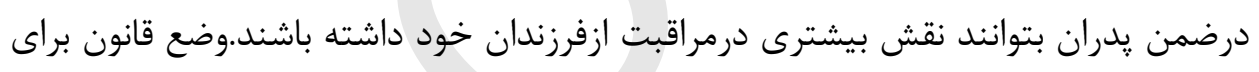

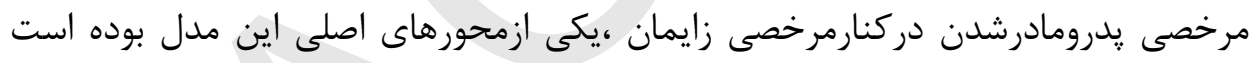

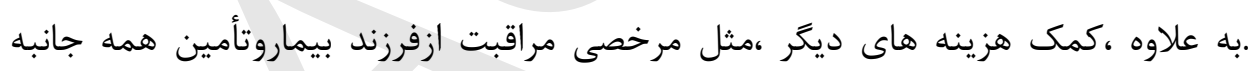

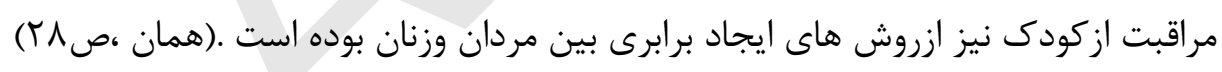

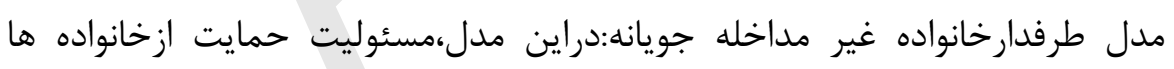

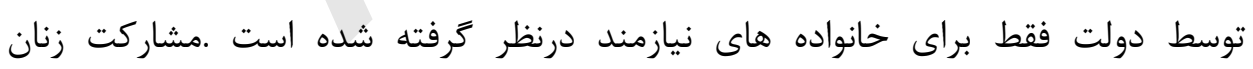

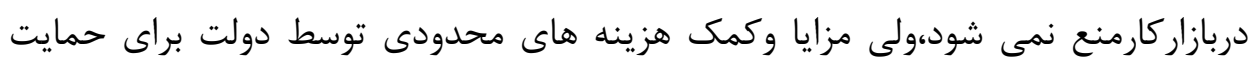

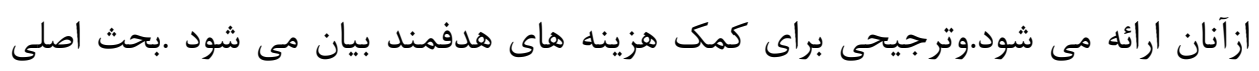

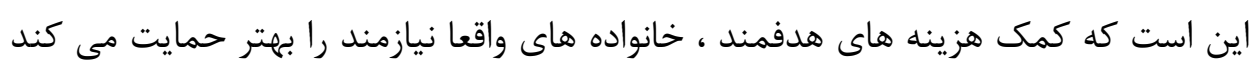

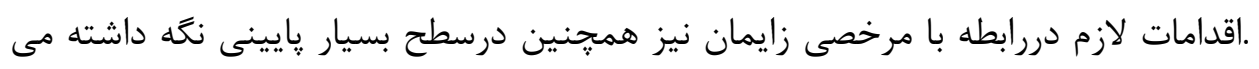


با توجه به جهارمدل سياست حمايت ازخانواده ها ، دربسيارى ازكشورها تركيبى ازمدل

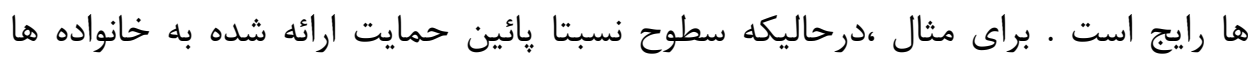

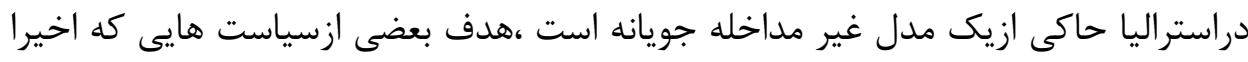

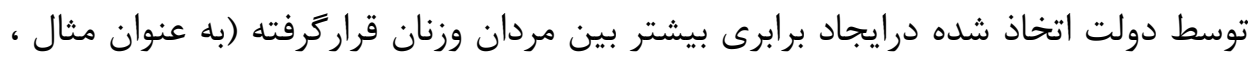

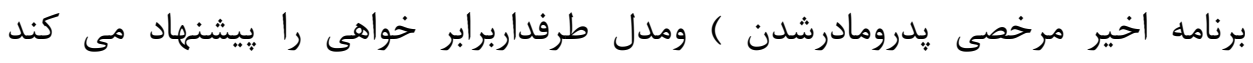

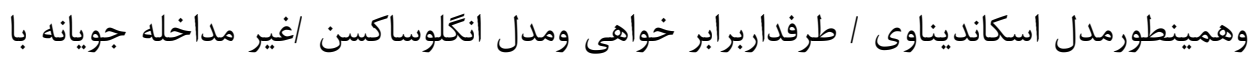

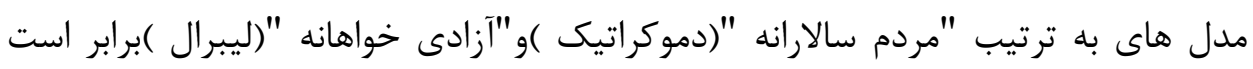

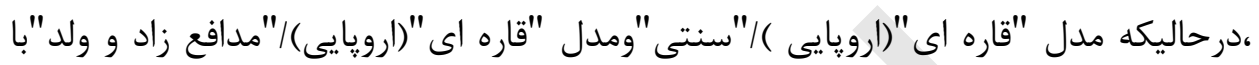

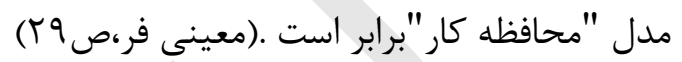

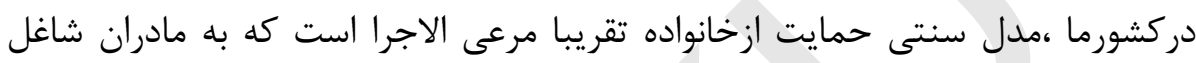

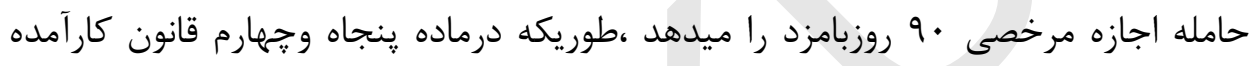

"كاركن زن مستحق (•9) روزرخصتى ولادى با مزد مى باشد كه يك ثلث آن قبل

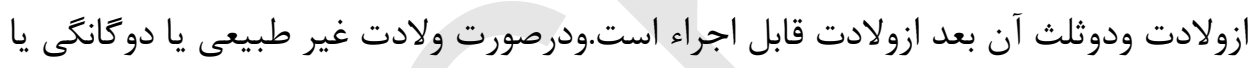

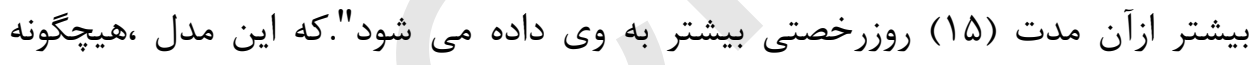

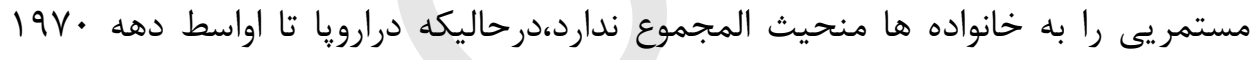

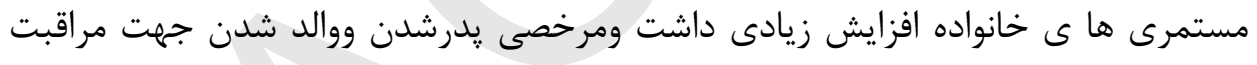

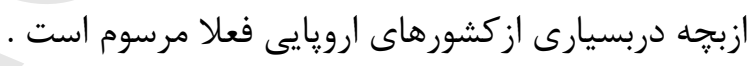

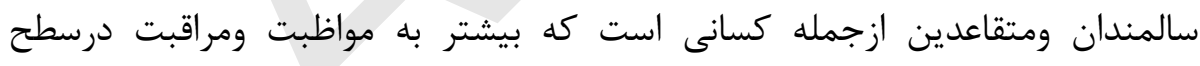

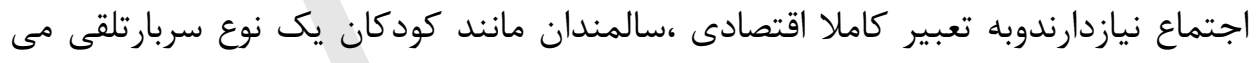

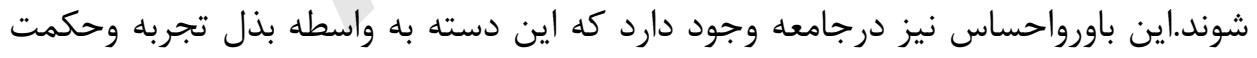

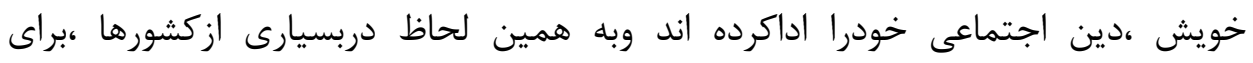

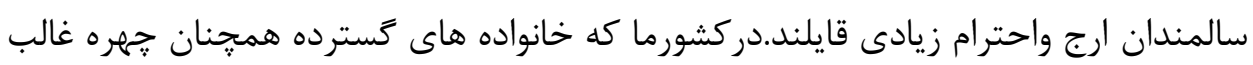

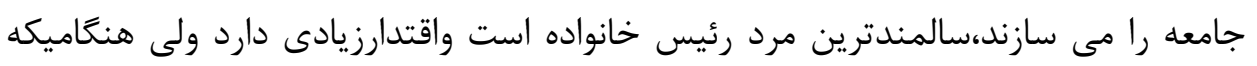

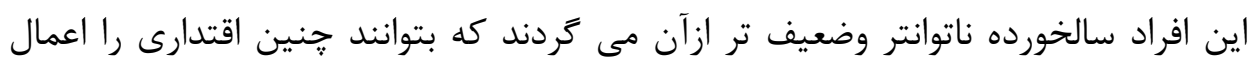

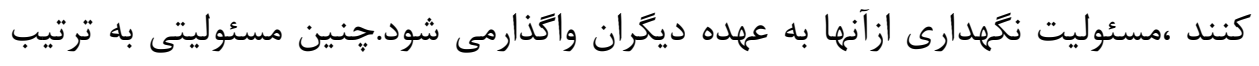

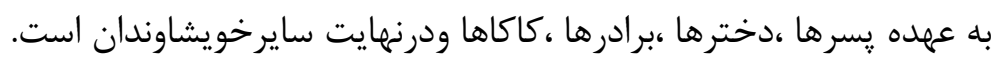


اما با بيدايش وكسترش پديده شهر نشينى وطرزتفكر صنعتى ،اين ارزش ها نيز تغيير

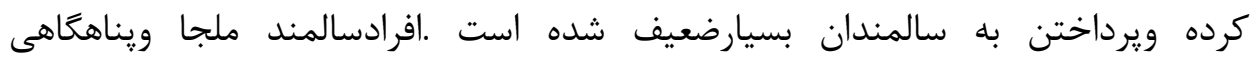

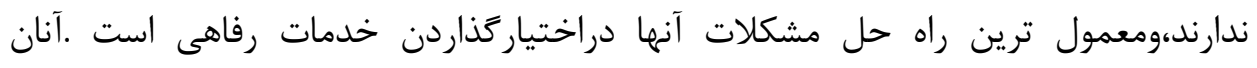

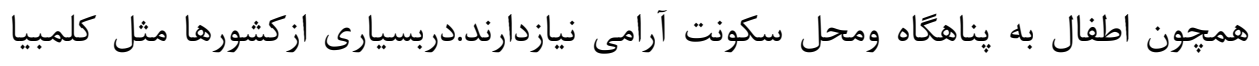

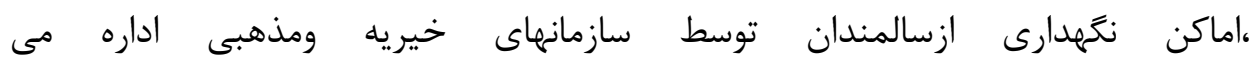

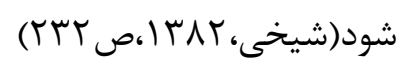

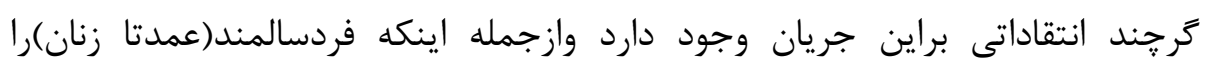

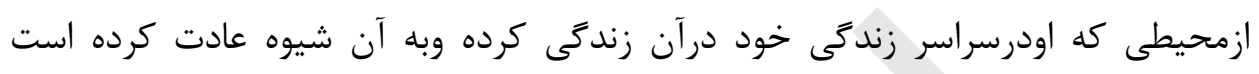

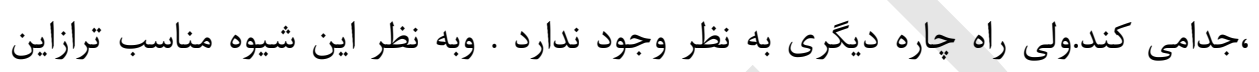

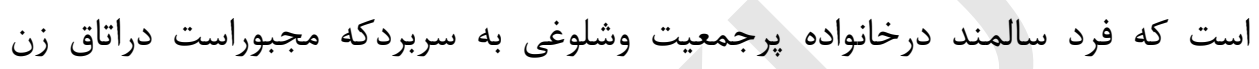

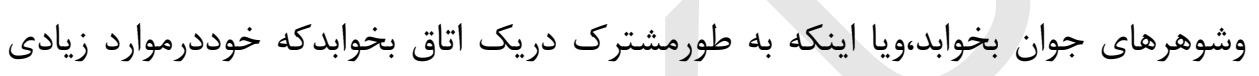
باعث بروزمسائلى مى شود.

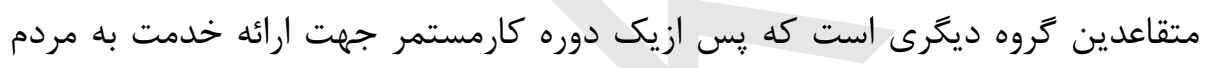

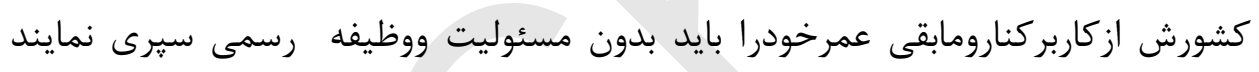

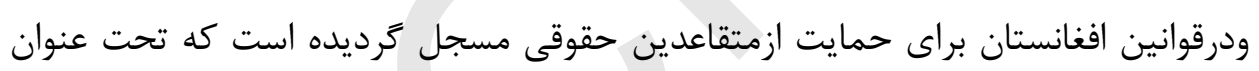

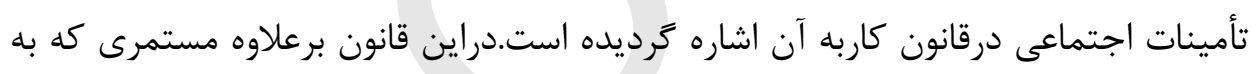

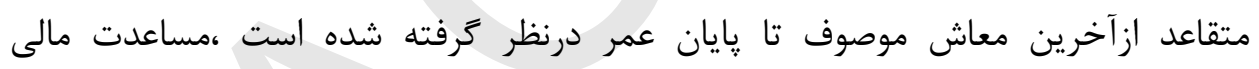

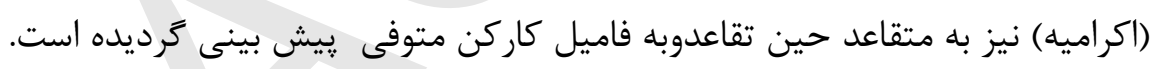

$$
\text { فقرات ه و V ماده يكصدوسى وجهارم قانون كار جنين مشعراست }
$$

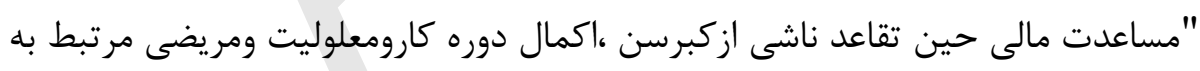

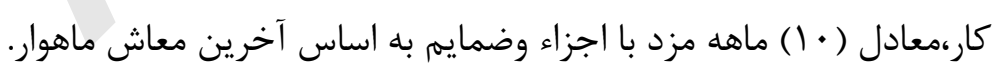

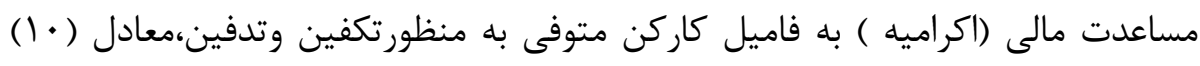

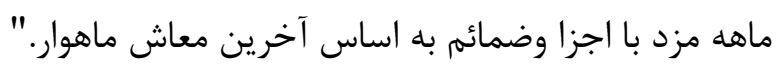

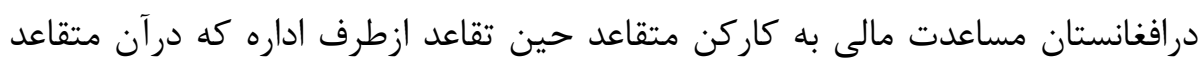

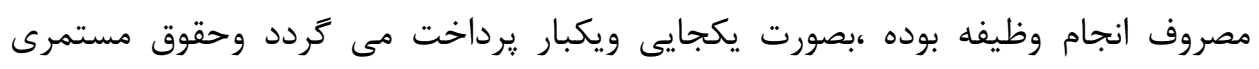

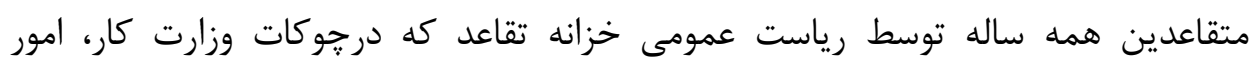

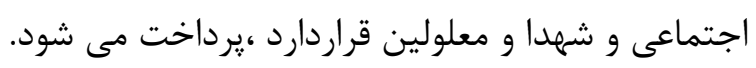


هم جنان براى بازماندگان شهدا،اطفال يتيم وبى سريرست نيز حقوق مستمرى يرداخت

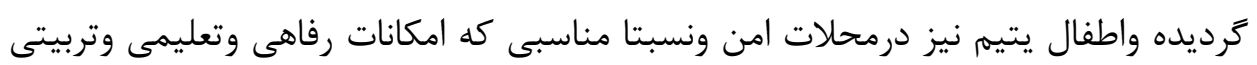

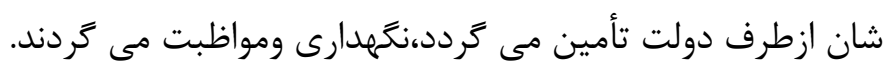

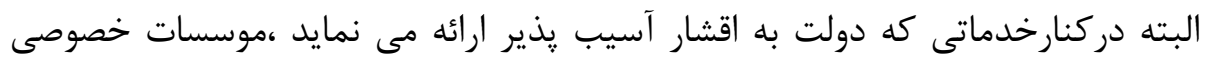

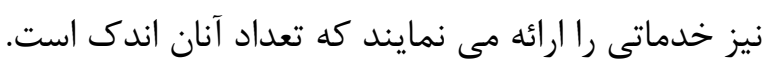

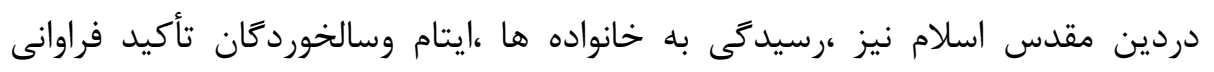

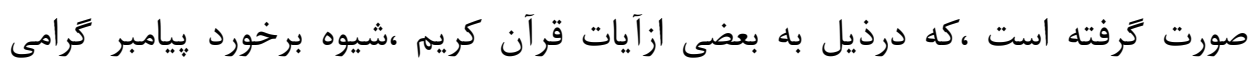

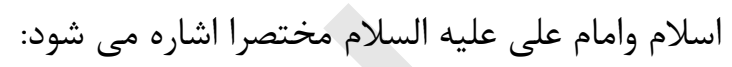

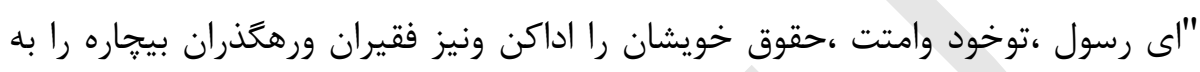

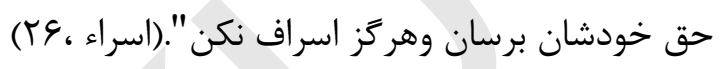

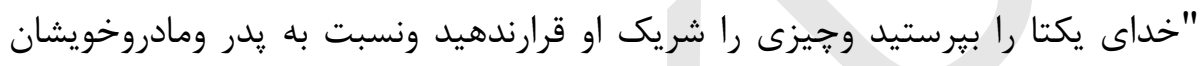

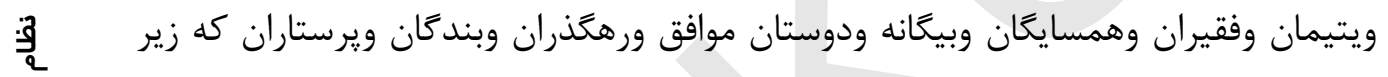

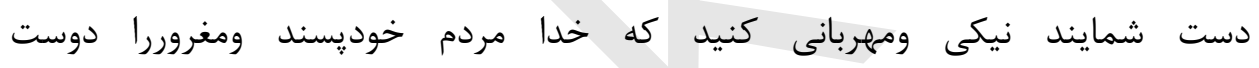

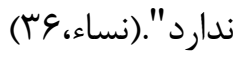

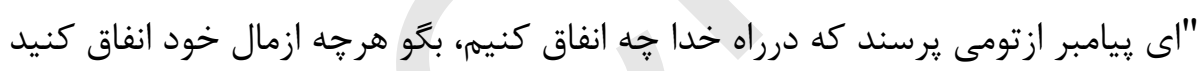

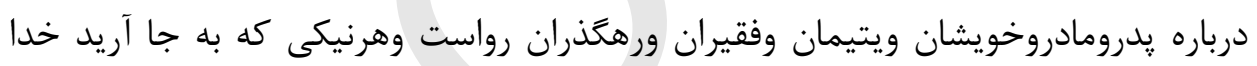

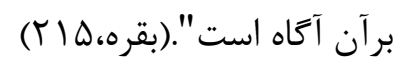

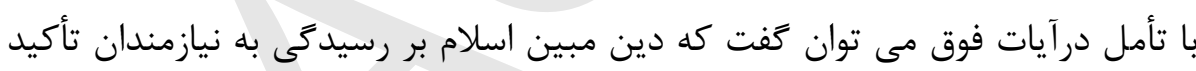

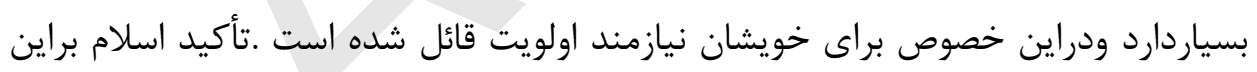

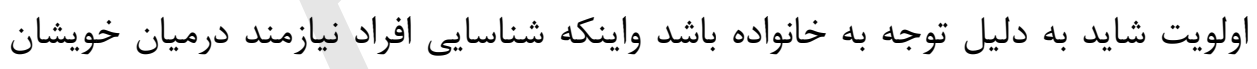

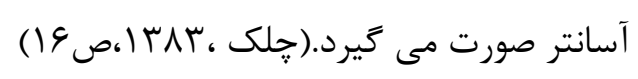

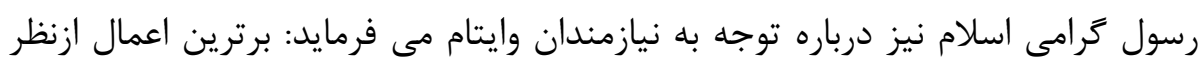

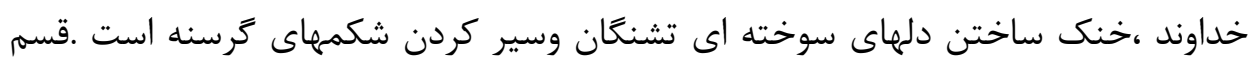

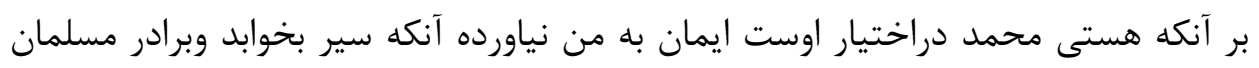

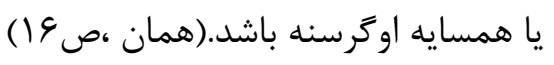

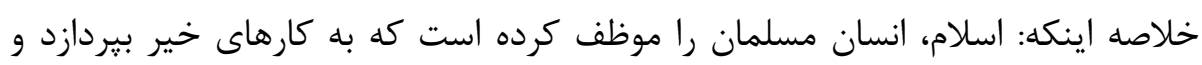

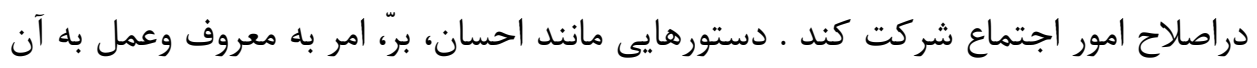


، ترحم، رأفت ومدارا، تعاون برخير، دستخيرى ازمحروم وكمك به فقراونيازيازمندان، انفاق

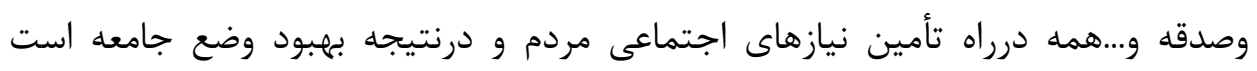

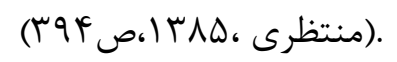

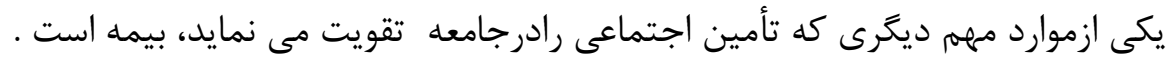

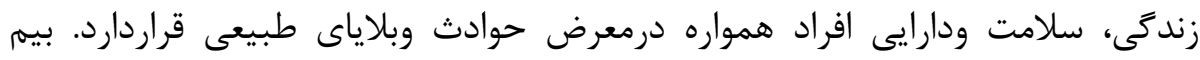

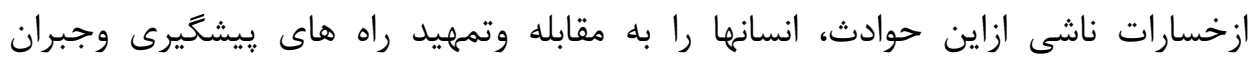

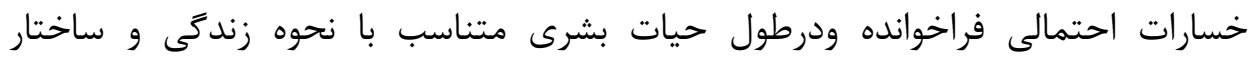

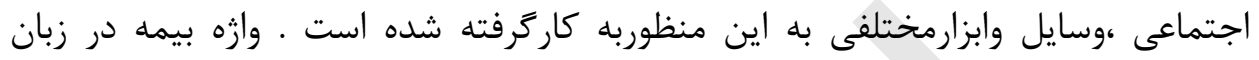

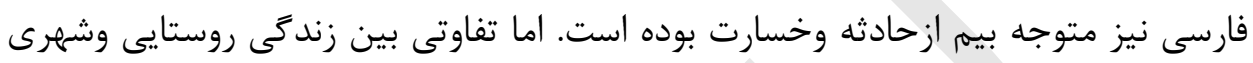

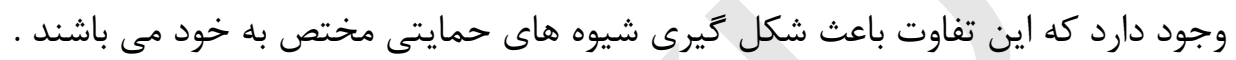

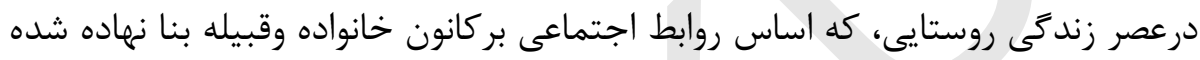

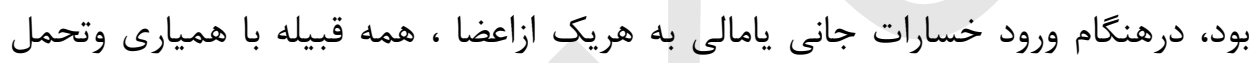

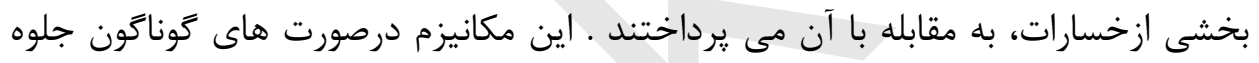

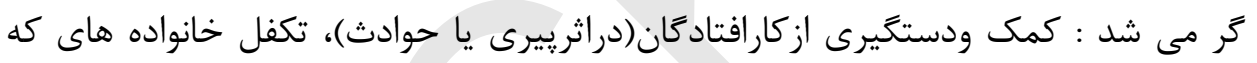

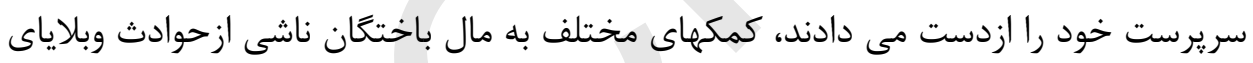

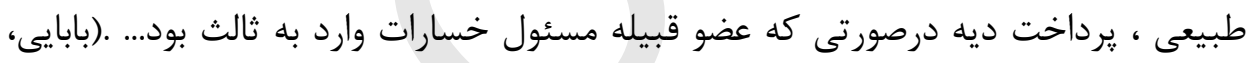

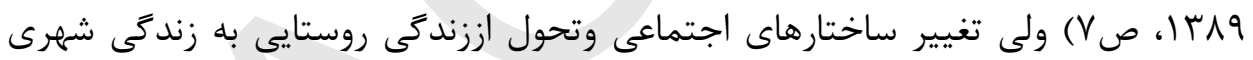

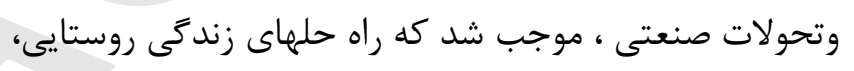

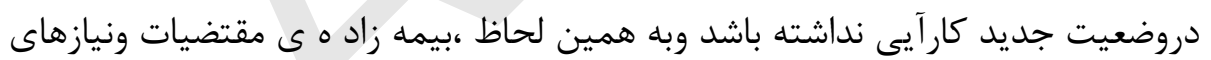

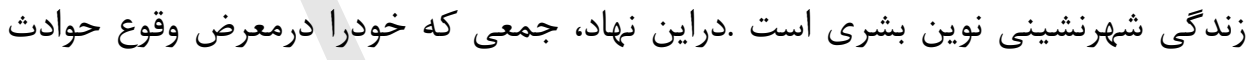

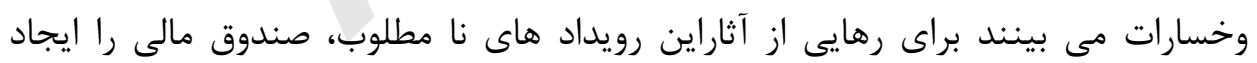

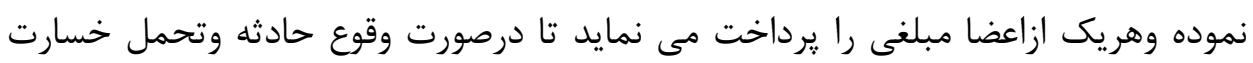

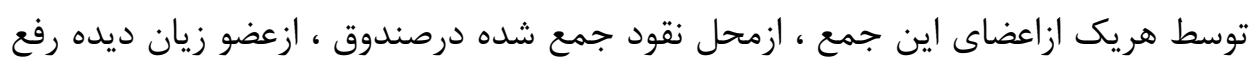

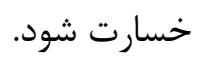

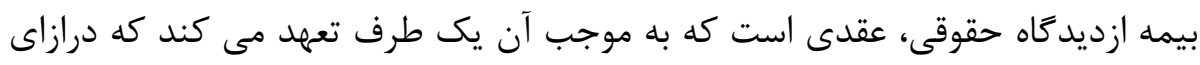

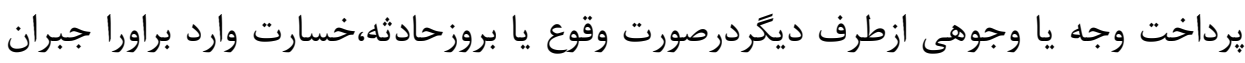

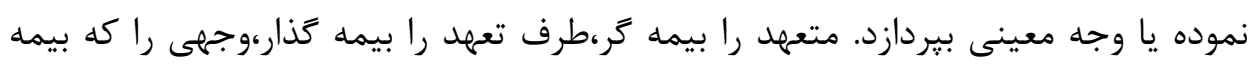


كذاربه بيمه گرمى يردازدحق بيمه وآنجه را كه بيمه مى شود موضوع بيمه نامند.(همان

$$
\text { (T) ب (T) }
$$

بيمه ازنظر فقه اسلامى : بيمه به عنوان نهاد جديد، موردتوجه فقهاى شيعه وسنى

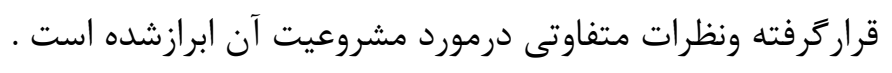

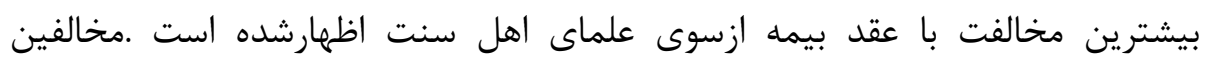

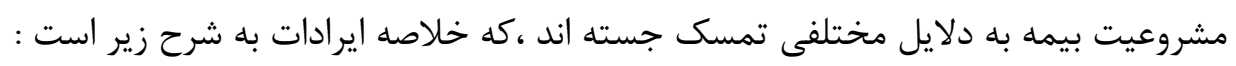

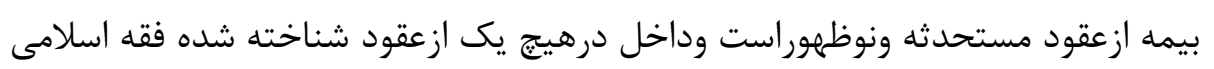

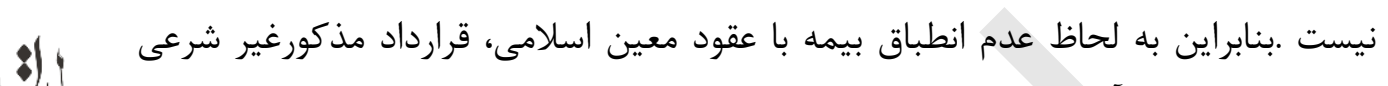

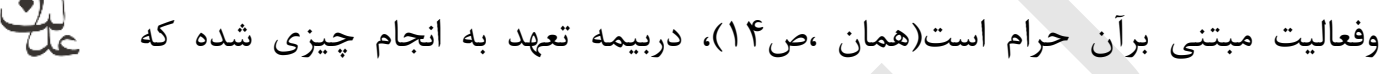

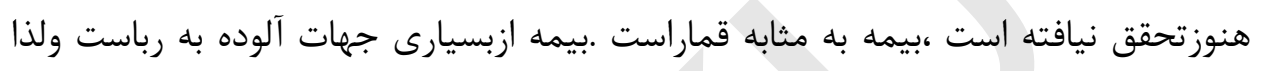

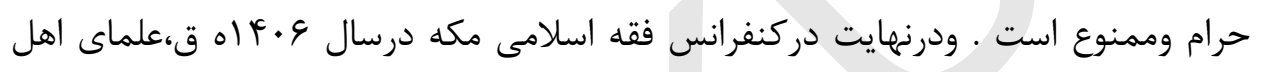

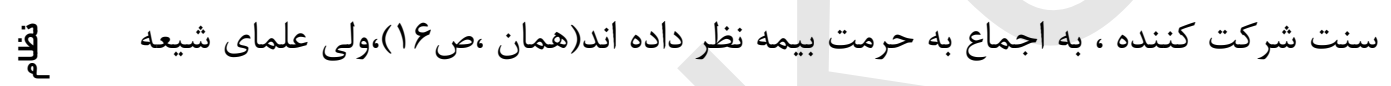

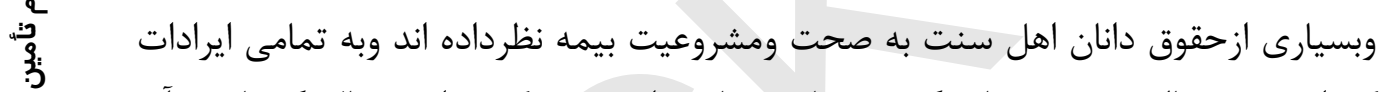

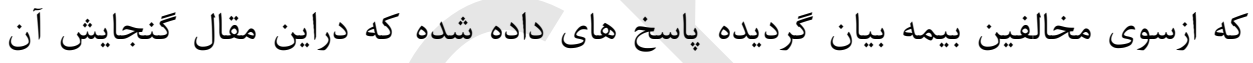

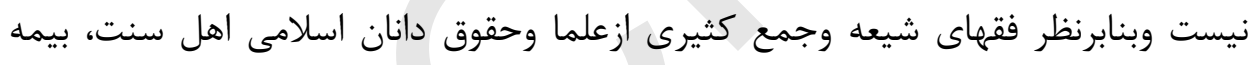

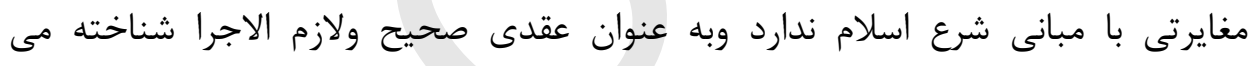

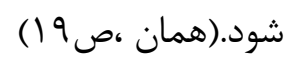
قرارداد هاى بيمه براساس طبيعت تعهدات قراردادى بيمه گر وبيمه گذاربه بيمه خسارات

$$
\text { وبيمه اشخاص تقسيم مى شوند: }
$$

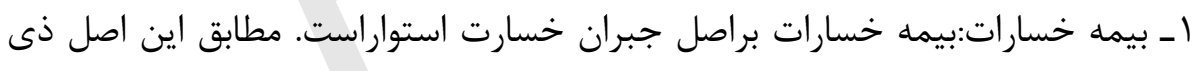

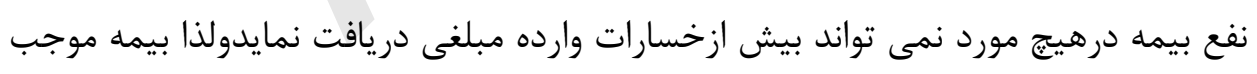
افزايش دارايى نمى شود. بيمه خسارات به دوبخش عمده بيمه اموال وبيمه مسئوليت تقسيم مى شى شود.

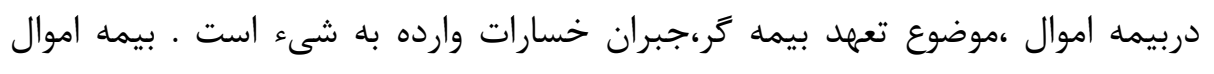

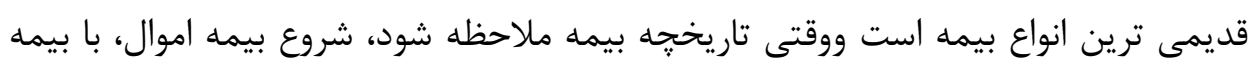

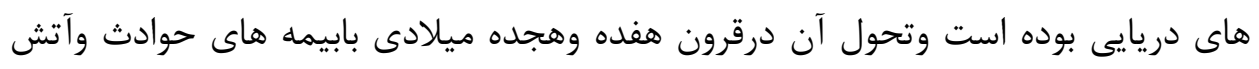


سوزى همراه بوده است. هدف بيمه اموال جبران خساراتى است كه بيمه كذارمستقيما ازلطمه به اموال ودارايى خود تحمل مي نمايد.

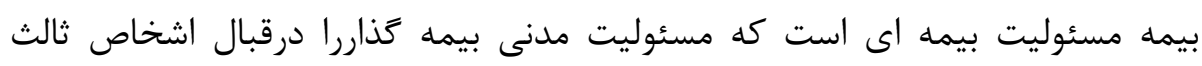

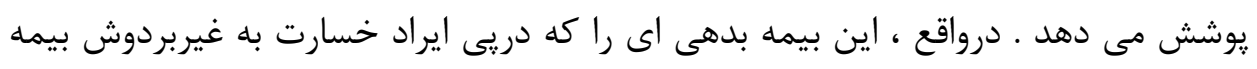

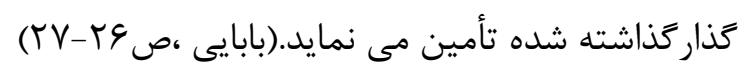

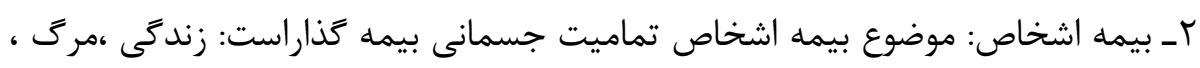

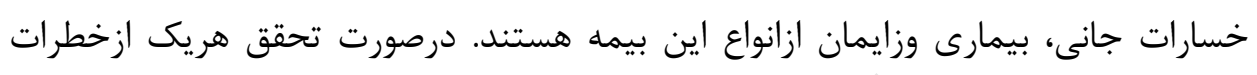

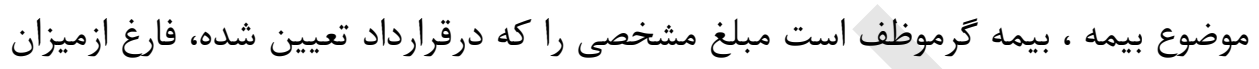

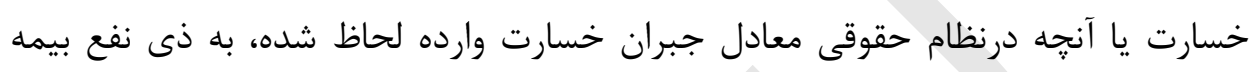

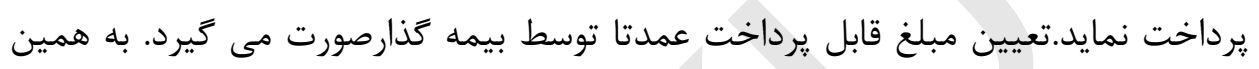

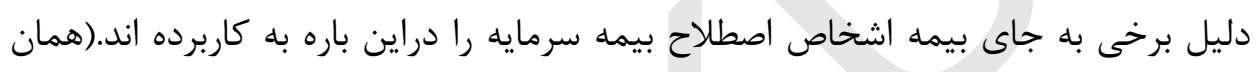

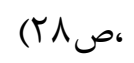

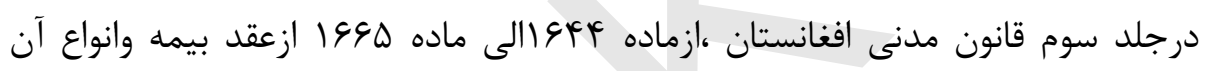

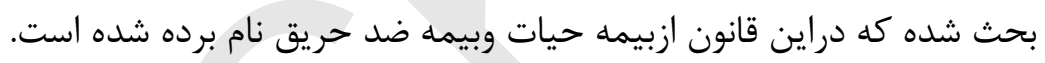

\section{نتيجه تيرى}

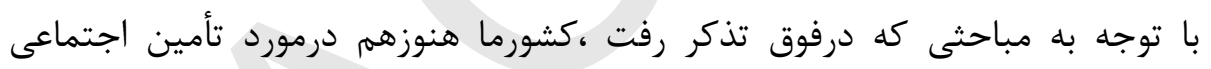

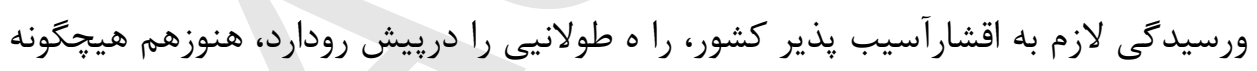

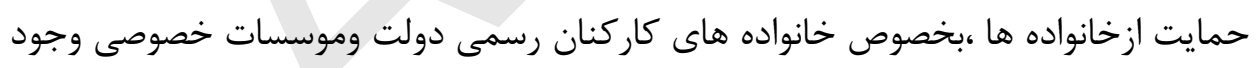

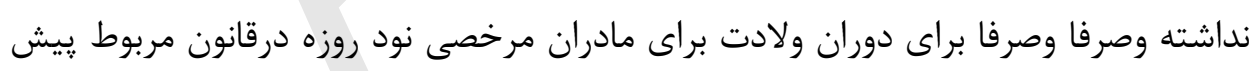

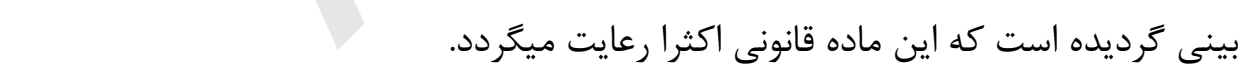

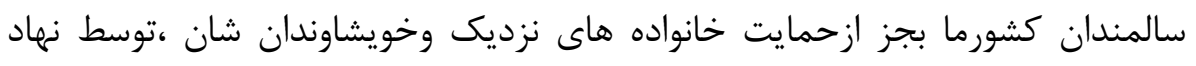

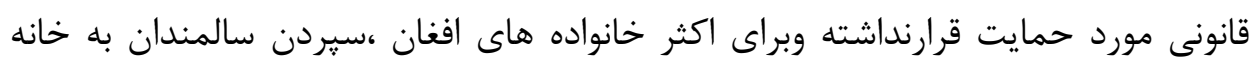

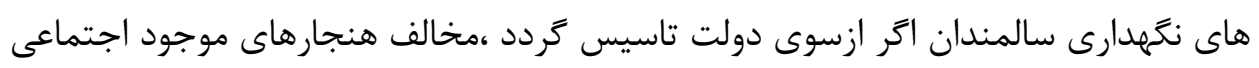

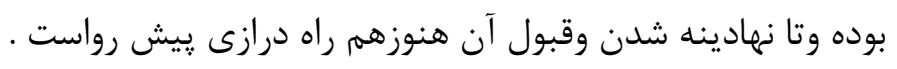

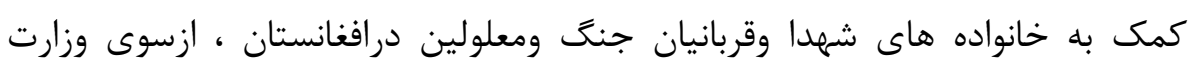

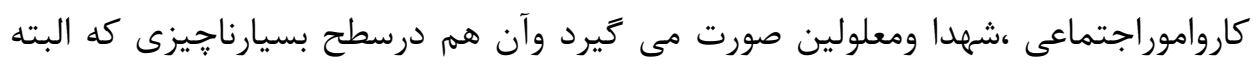


كميت اين نوع كمك ها به اقتصاد ورشد كشورارتباط دارد كه با تاسف، وطن ما فعلا ازلحاظ

$$
\text { وضعيت اقتصادى درحالت خوبى قرارندارد. }
$$

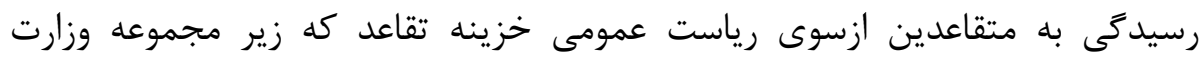
كارواموراجتماعى ميباشد ،صورت مى كيرد وبا توجه به وضعيت عمومى فعلى كشور نسبتا

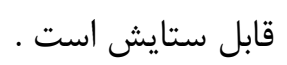

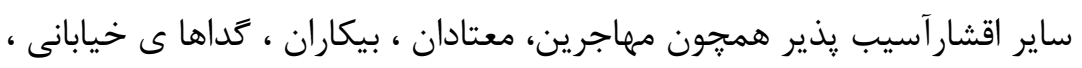

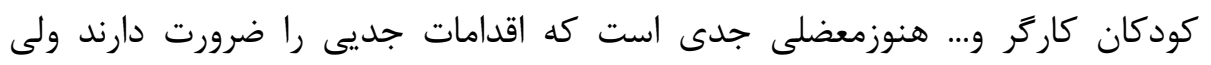

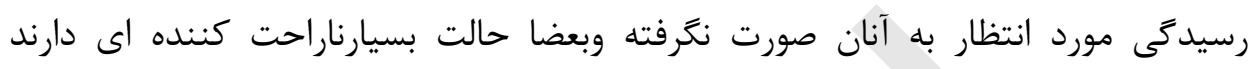

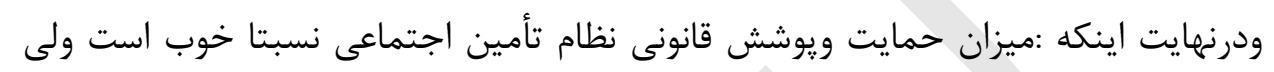

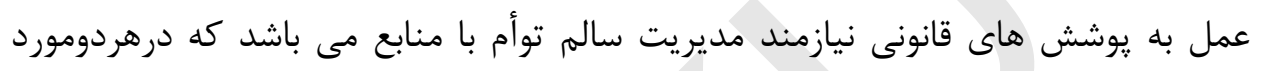
مشكلاتى وجود دارد.

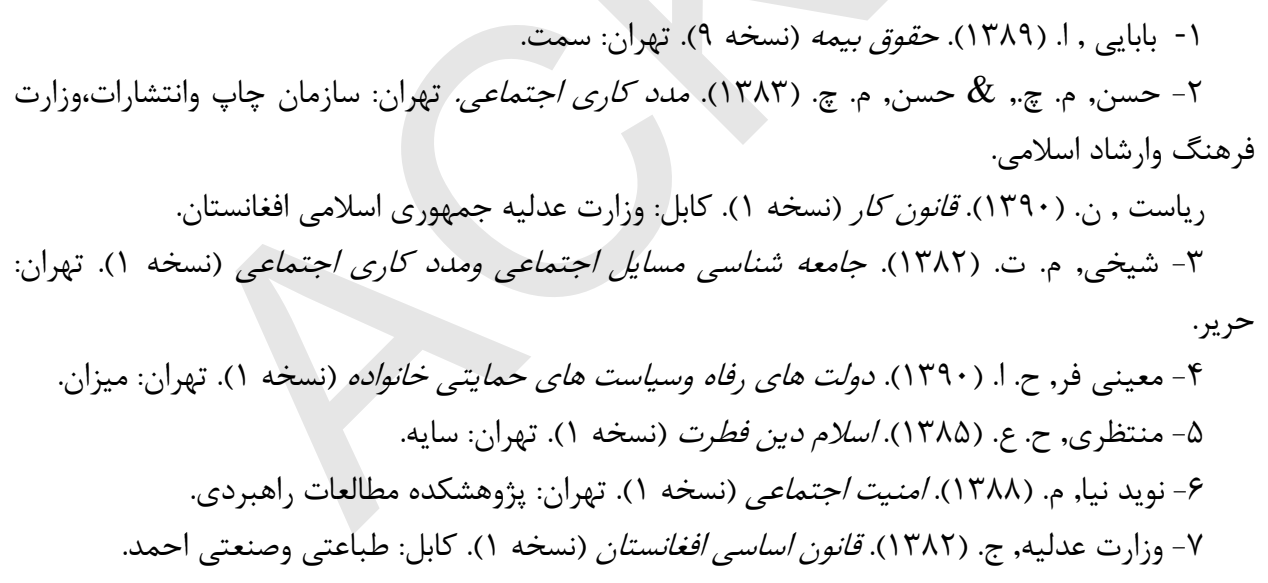

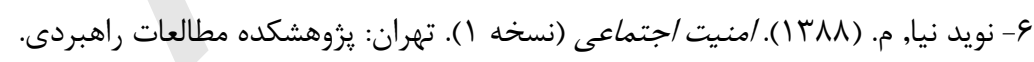

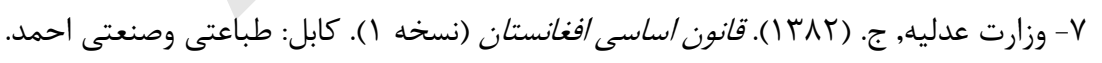

Article I

ᄉ- International Social Security Association. $(r \cdot 11)$. Retrieved I $11, r \cdot 11$, from http://www.issa.int/Topics/About-social-security 


\section{ه عقد اركان او شرطونه}

خيرنوال فضل الرحيم محمود

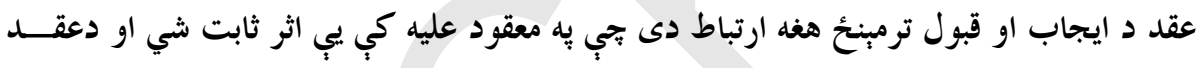

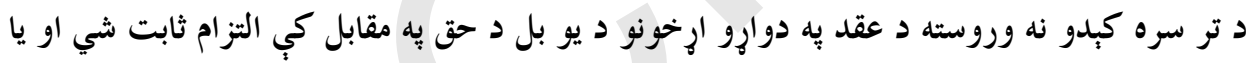

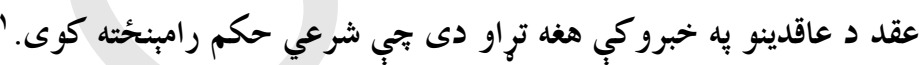

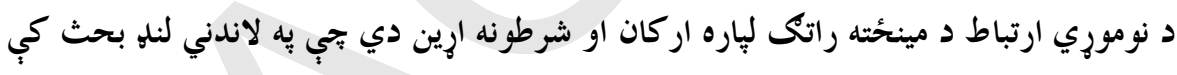
د عقد اركان او شرطونه خيرل كيري. لومرى: د عقد اركان

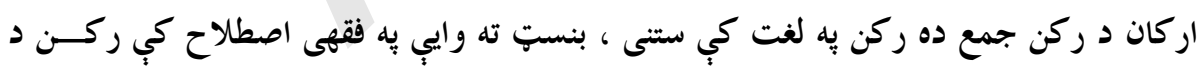

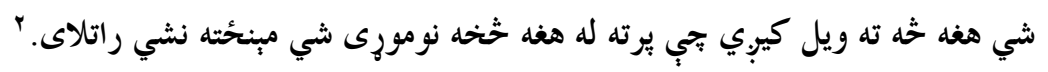

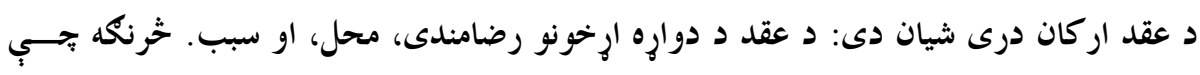

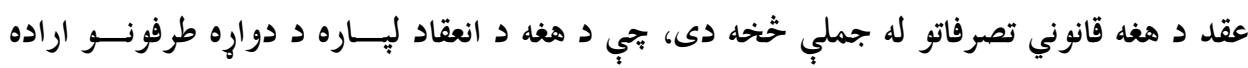

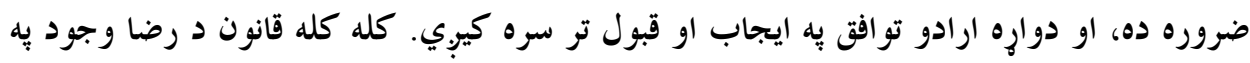

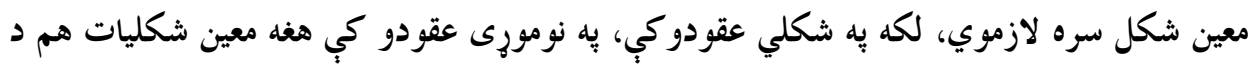

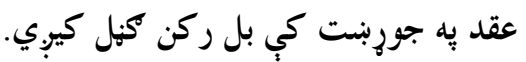




$$
\text { الفه لاندب كربنو كي بِه مختصر دول د عقد اركان بيانيبِى: }
$$

$$
\text { رضا يه عقد كي اساسي ركن دى او د لاندب عناصرو خخه جوريوبى: }
$$

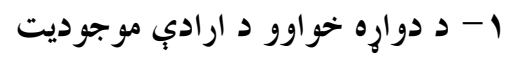

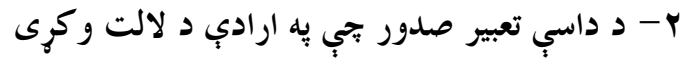

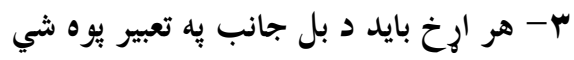

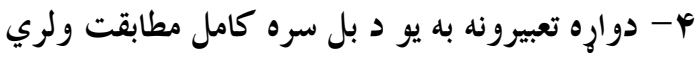

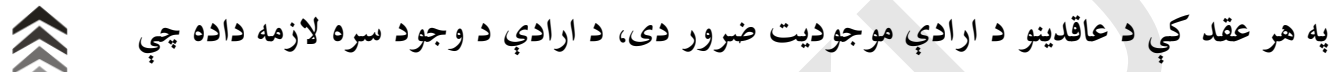

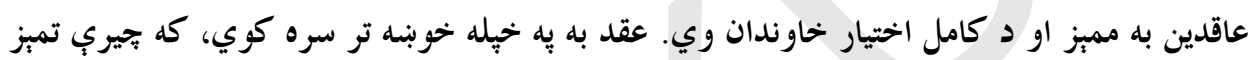

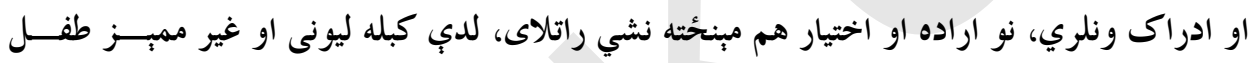

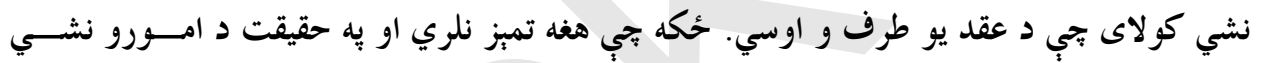

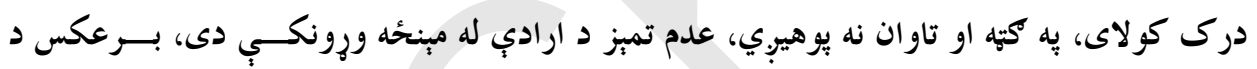

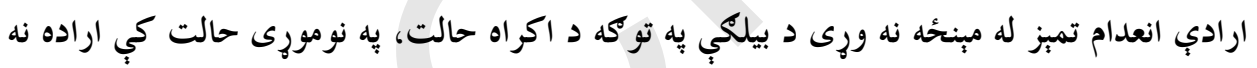
وي، خو تمبز يه خبل حال باقى باتى وي.

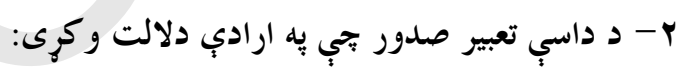

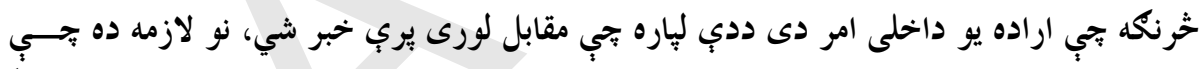

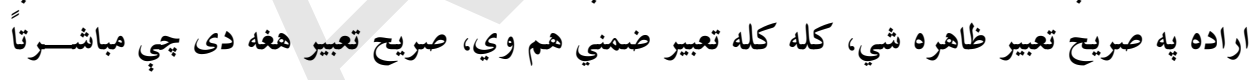

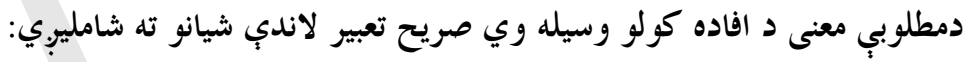

1- 1 د لفظ استعمال.

$$
\begin{aligned}
& \text { ץ- د اشارب استعمالول لكه د سر بنورول. } \\
& \text { ب- دكنايي استعمالول. }
\end{aligned}
$$

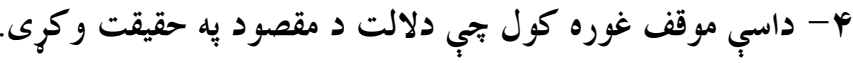

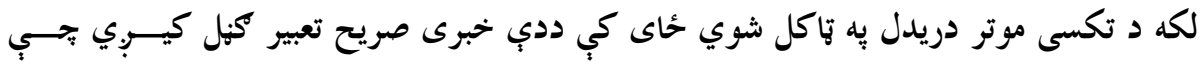
خاونديي هغه د خلكو د سورلى او انتقال لِاره درولى ده. 


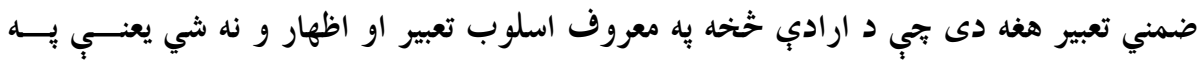

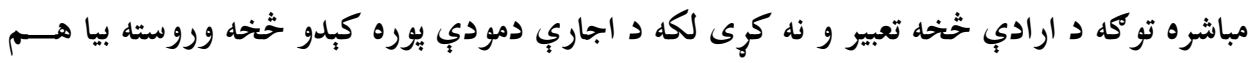

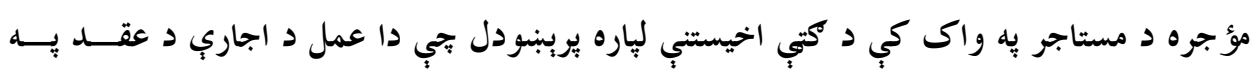

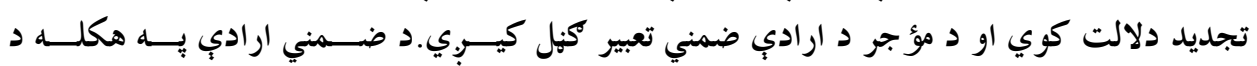

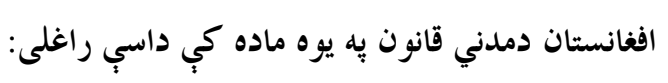

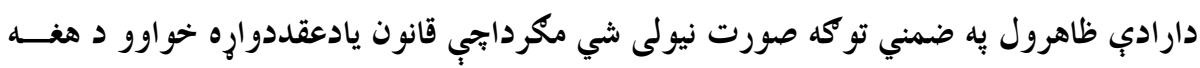
صراحت شرط كرى وي.

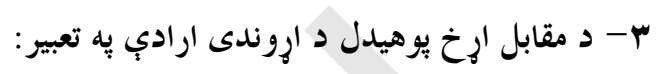

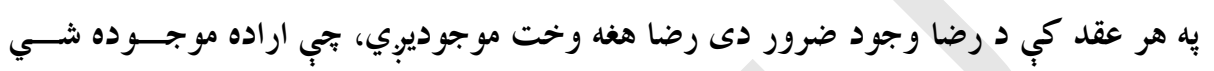

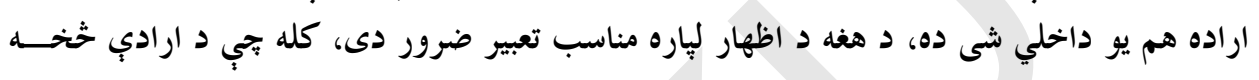

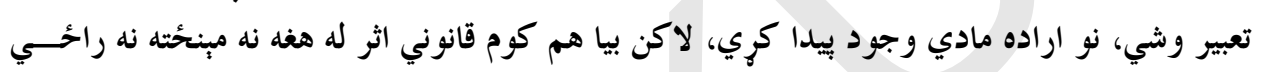

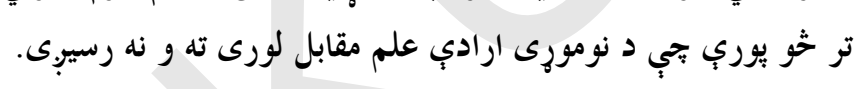

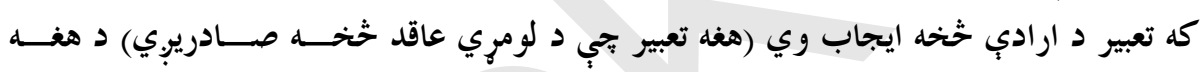

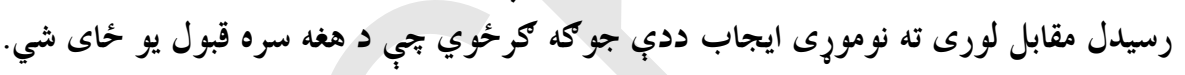

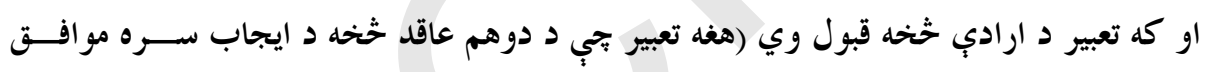
صادر شي) د هغه رسيدل مقابل لوري ته عقد تر سره كوي.

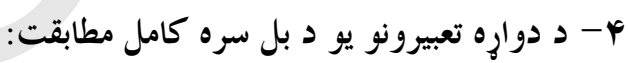

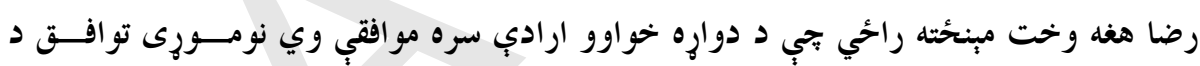

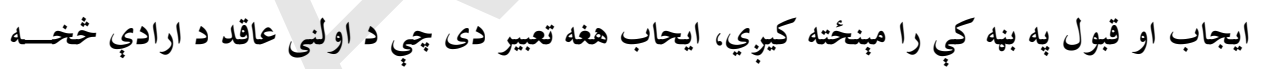

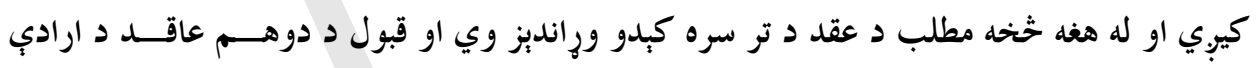

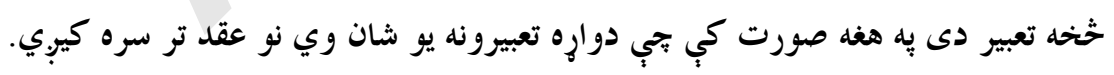

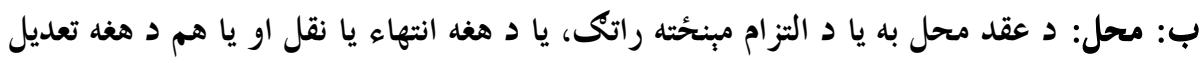

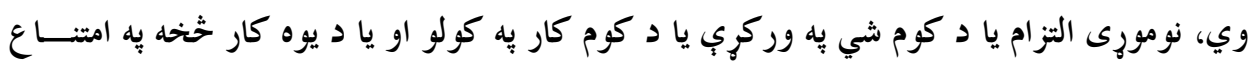

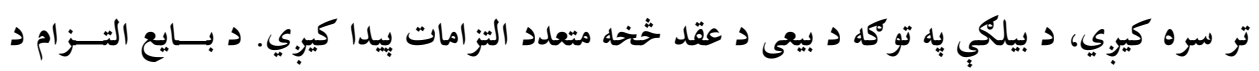

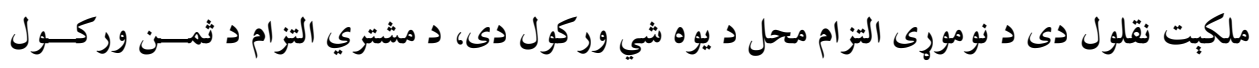

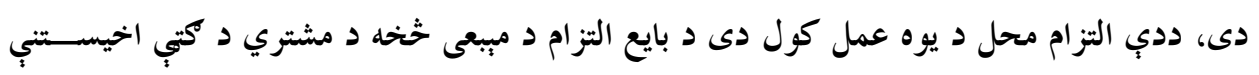




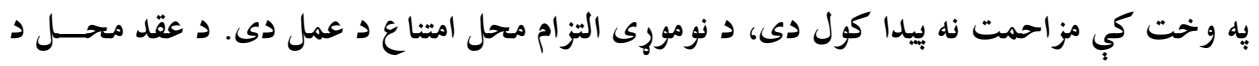

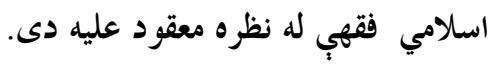

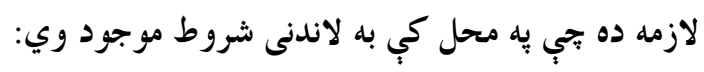

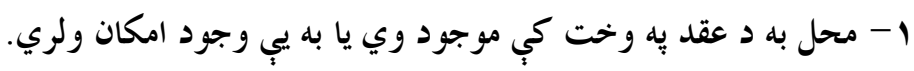

r - محل به معين وي يا به د تعين ورج وي.

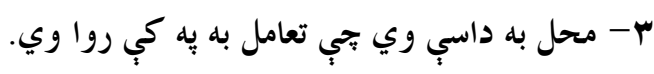

ج: سبب:

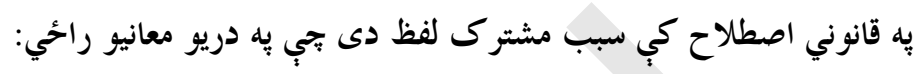

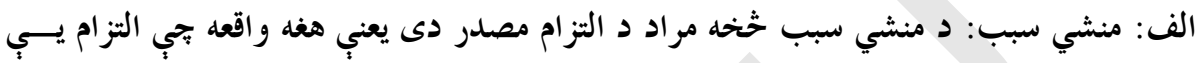

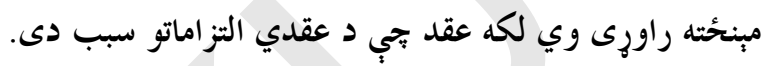

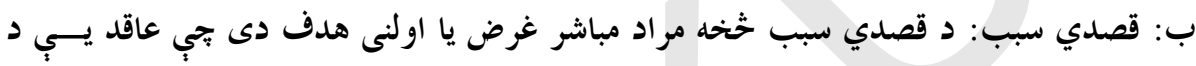

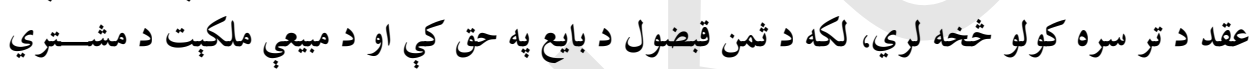

\section{دوهم: د عقد شرطونه}

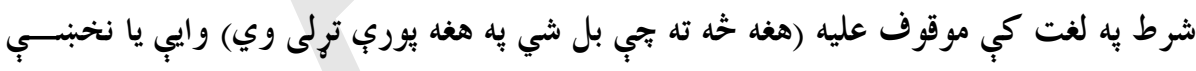

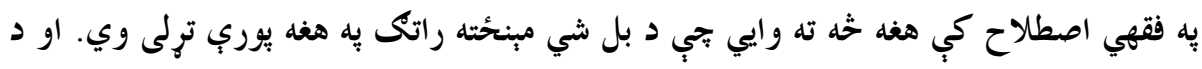

هغه د حقيقت خخه خارج وي.

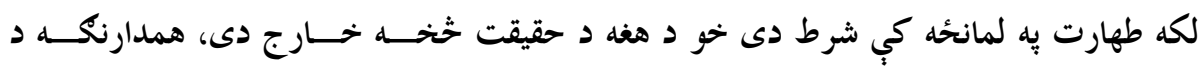

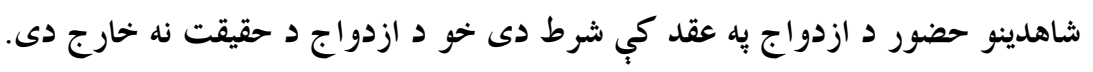


خرنكه تجي مخكي ذكر شول جب د قانون له نظره د عقد اركان درى شيان دى هغه عبارت دى

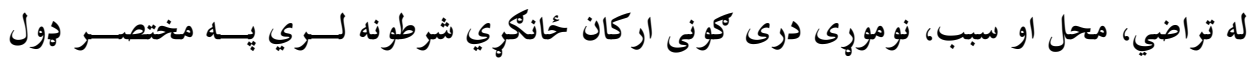
بيانيوي: د تراضي د تحقق او انعقاد لهاره دادى تجي د مميز شخص له خوا به صادر شوي وي بل شـــرط

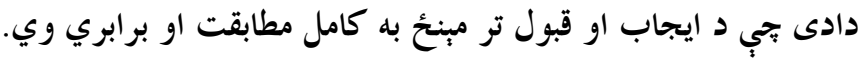

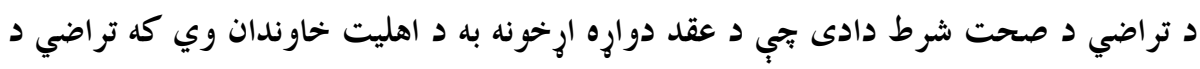

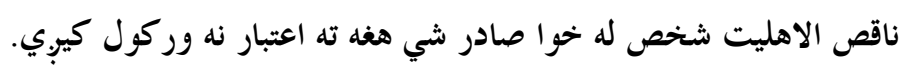

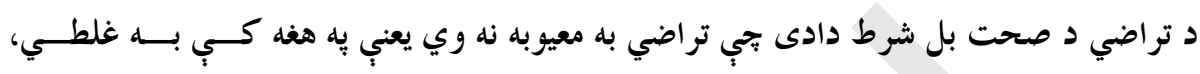

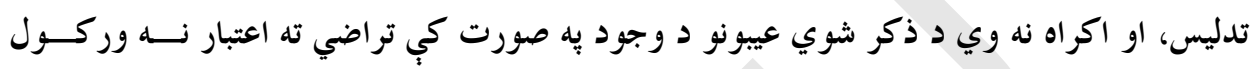

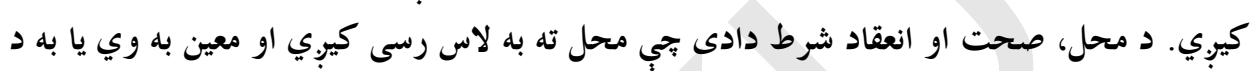
تعين كولو وروي.

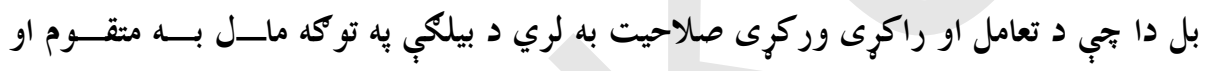

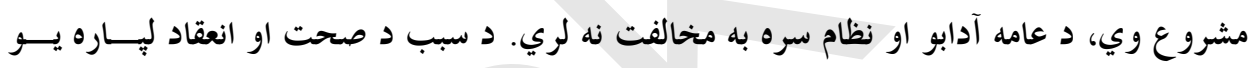

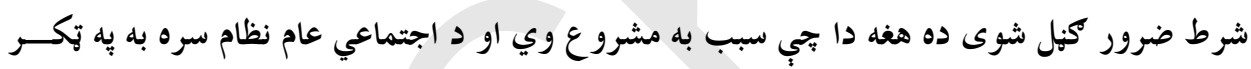

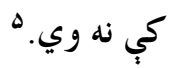

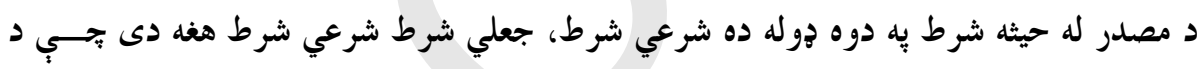

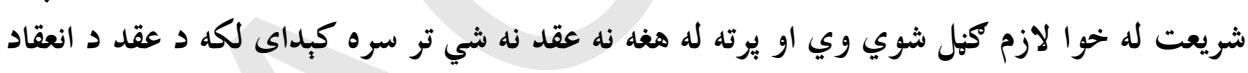

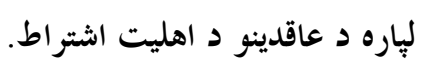

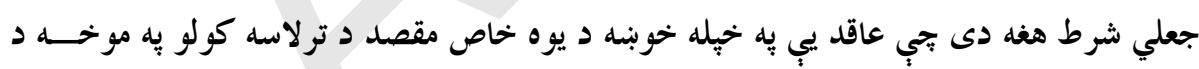

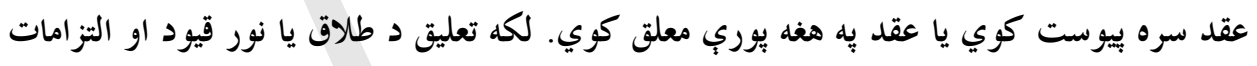

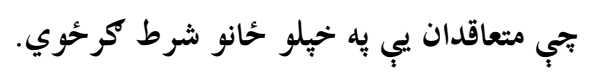

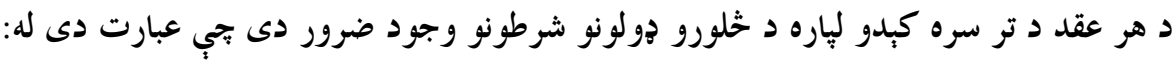

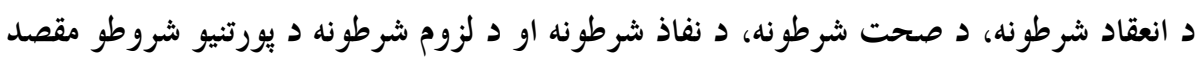

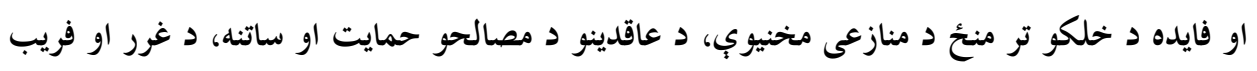

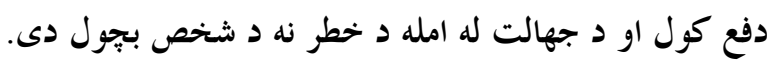


د عقد شرعي شرايط بِه لاندب تو كهه دى:

1- إن د انعقاد شرطونه

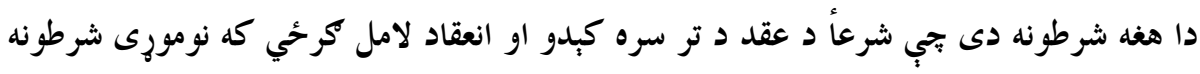

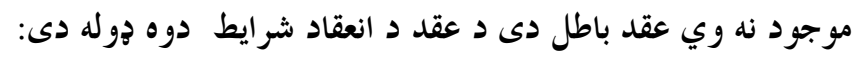

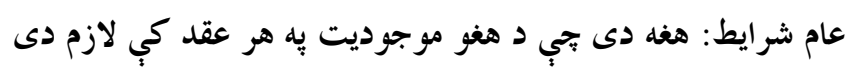

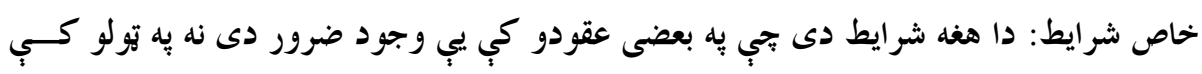

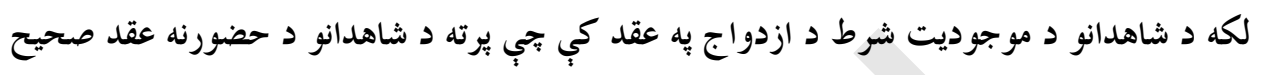

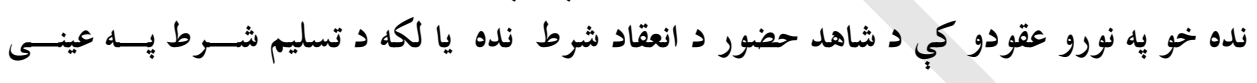

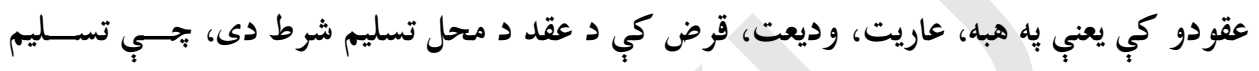
متحقق نشي عقد باطل دى. د عقد د انعقاد عام شرايط هغه شرايط دى بجي وجود يب به صيه صيغه د عقد، عاقد او معقود عليسـه

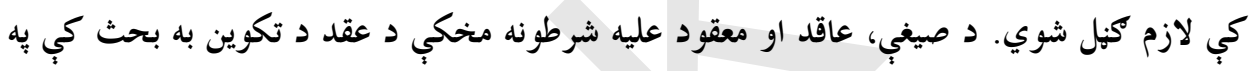

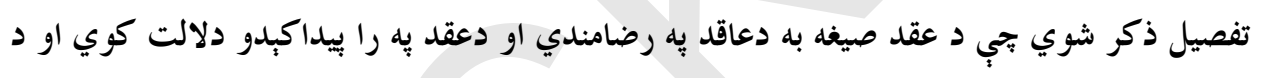

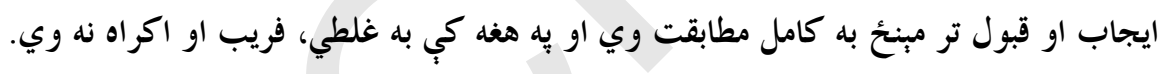

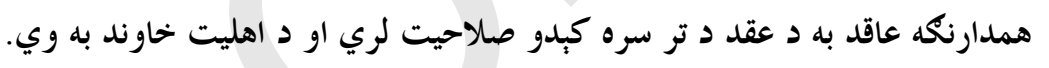

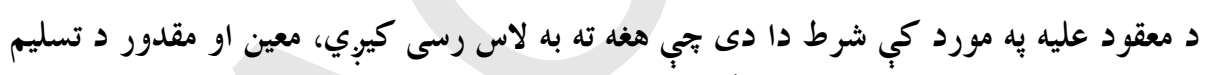

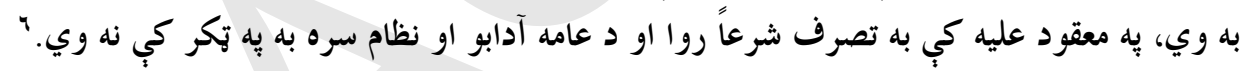

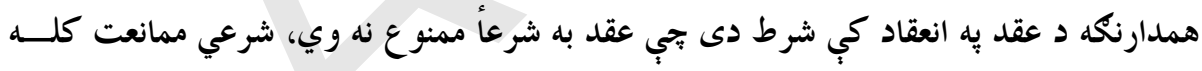

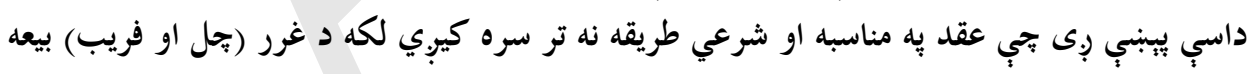

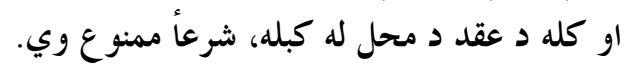

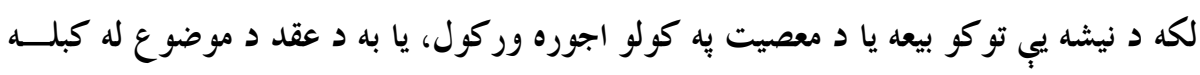

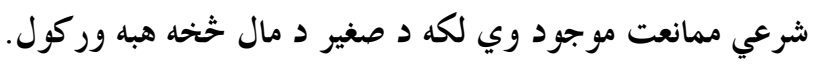

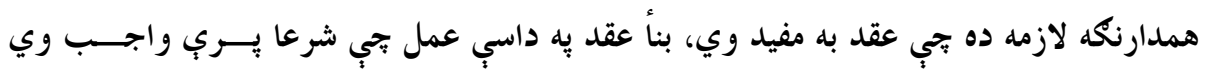

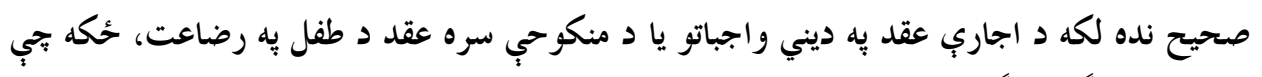

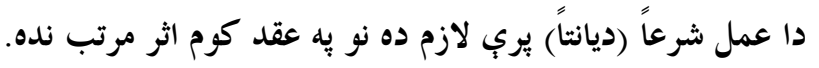


Y Y-د عقد د صحت شرطونه:

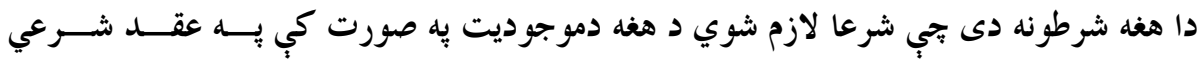

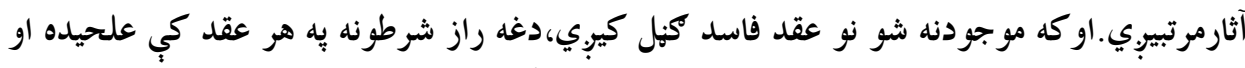

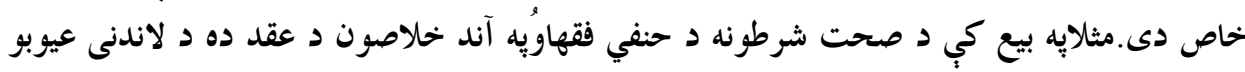
خخه:

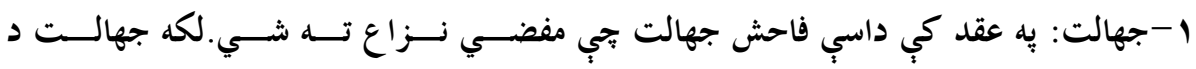

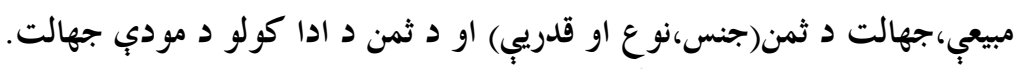

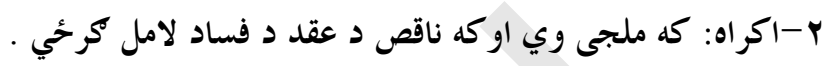

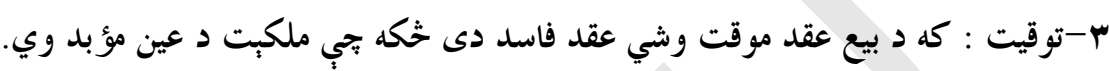

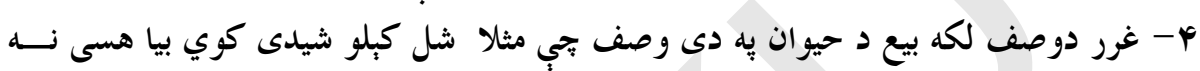

ه- ضرر: لكه بيع ديو متر تو كر، دكندلب كاليو خخه يا يو تير د كوتى د سقف خخه.

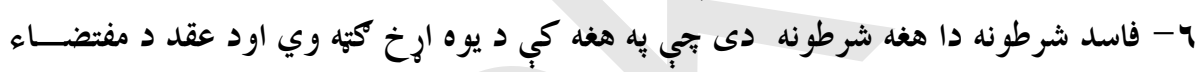

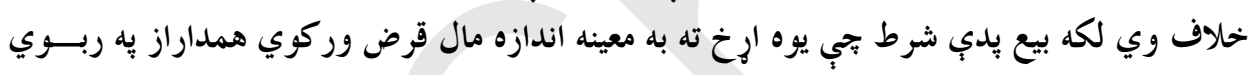

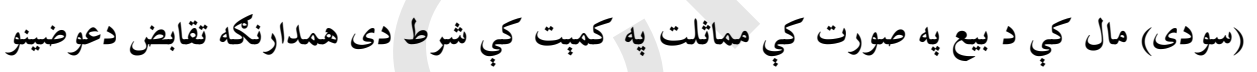
شرط دى (سودى

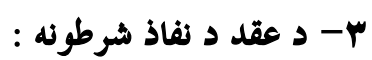

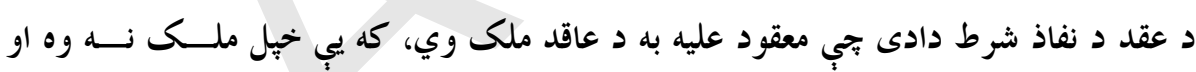

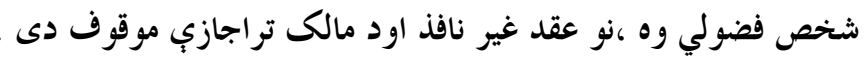

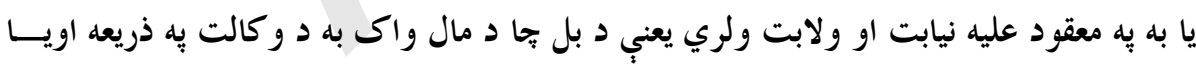

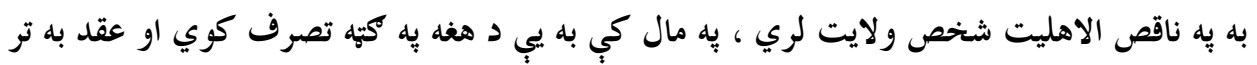

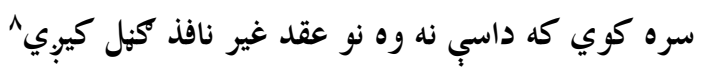

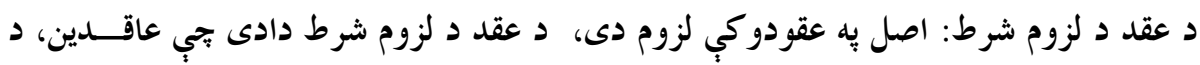

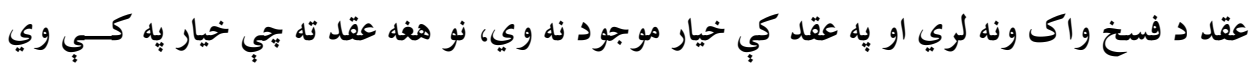




\section{به عقد كي د جعلي شرايطو ايبنودل:}

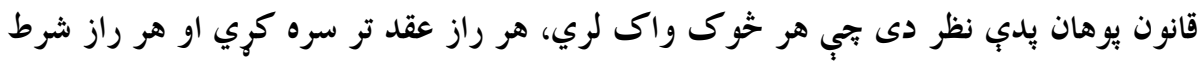

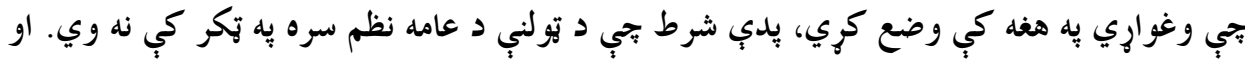

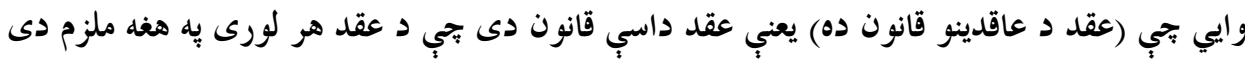

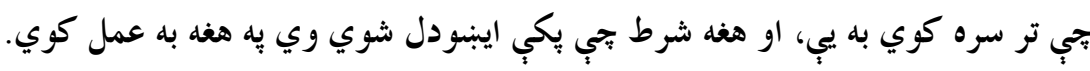

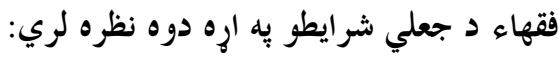

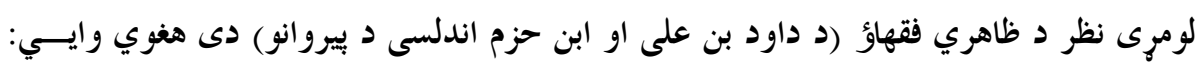

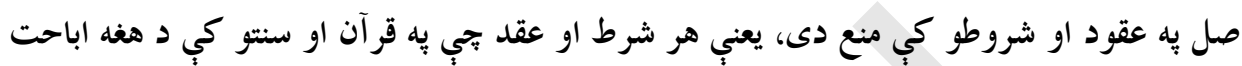
نه وي ذكر شوي هغه باطل دى.

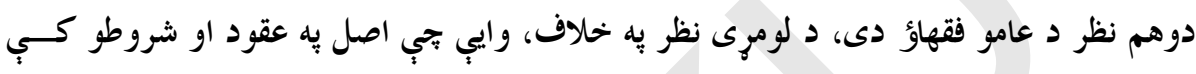

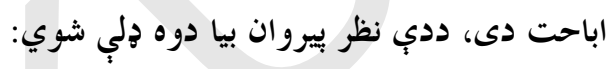

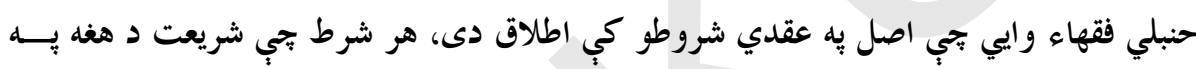

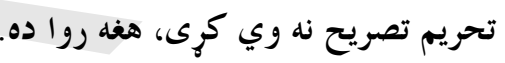

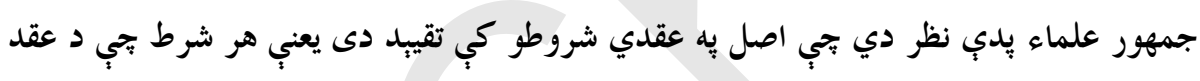

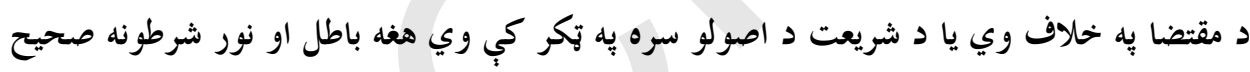

كه ذكر شوي نظرونونه ته حير شو به مالي عقودوكي د حنبلي فقهاؤ نظر تجي عاقدينو ته به عقد

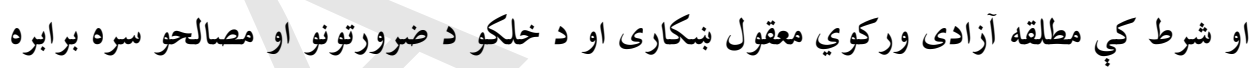

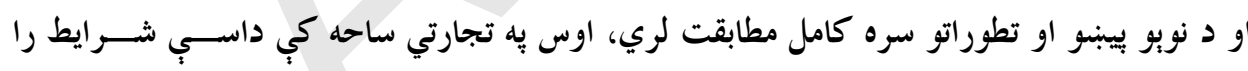

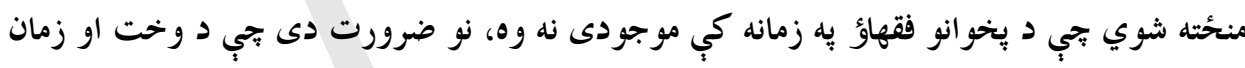

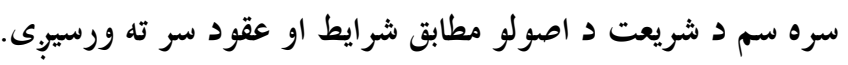

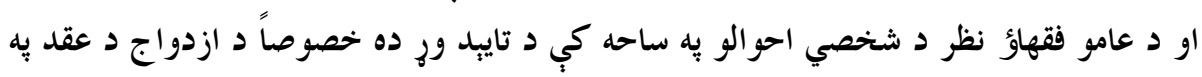

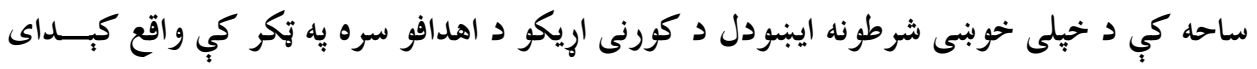




\section{د شرط به اره د حنفي فقهاؤ دريخ:}

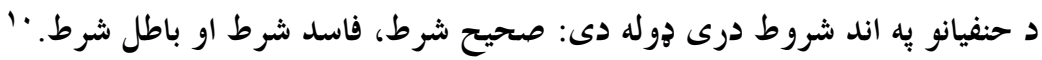

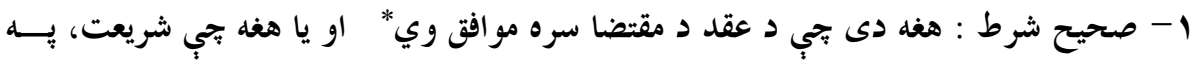

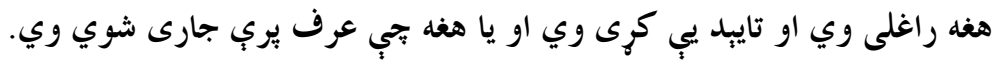

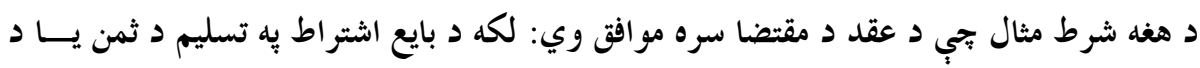

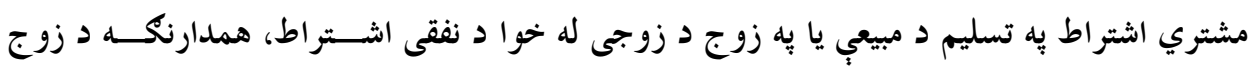

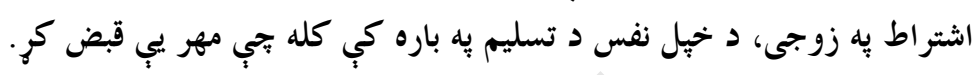

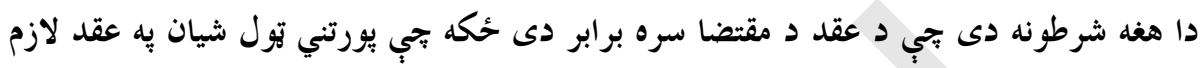

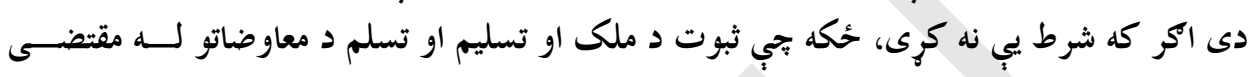

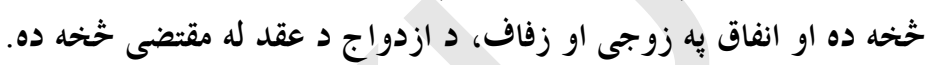

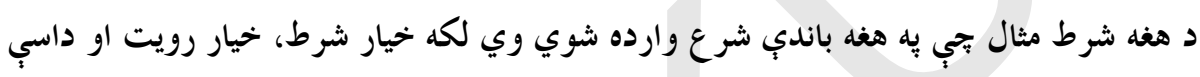

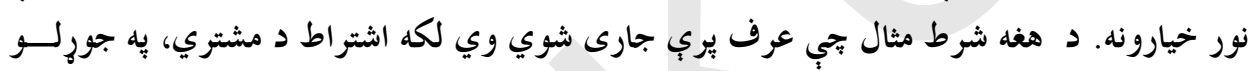

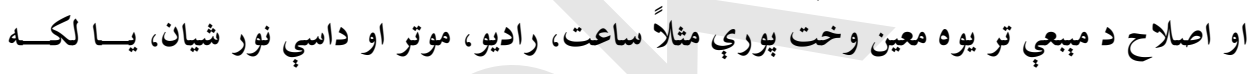

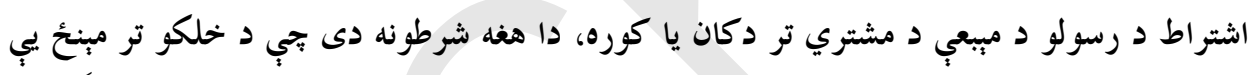

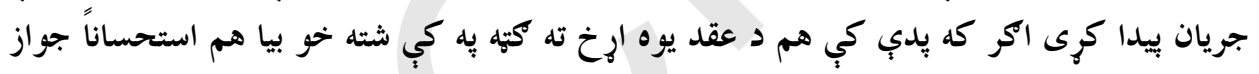

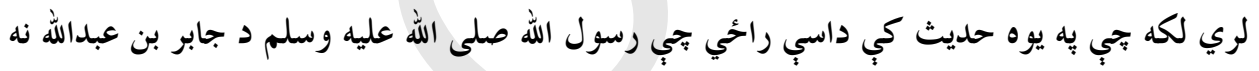

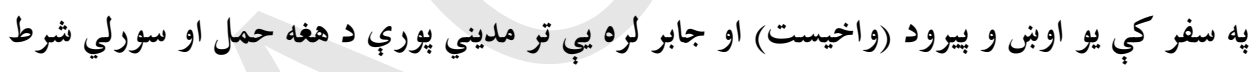
وكرحوله.

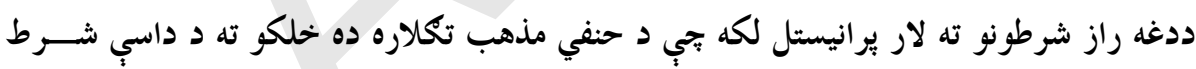

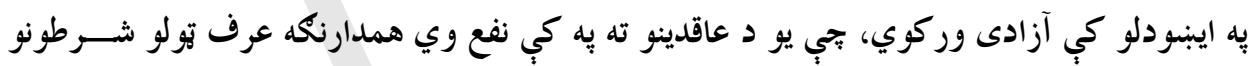

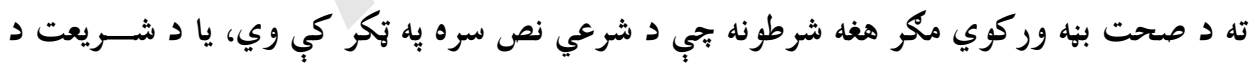

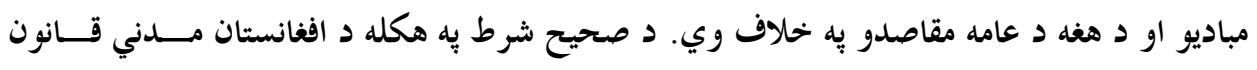

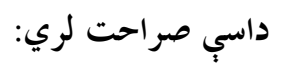

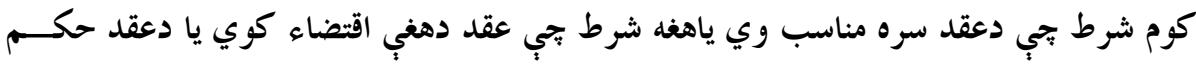

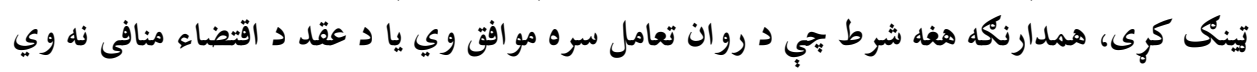


r- فاسد شرط: هغه دى تب د صحيح شرط مواصفات به كب نه وي يعنب داسب شـــرط وي

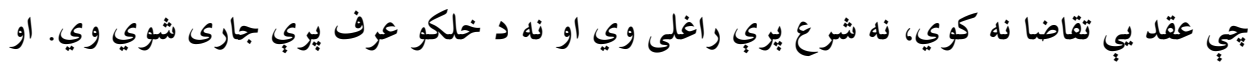

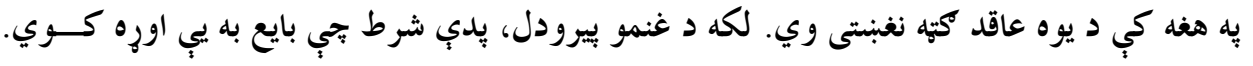

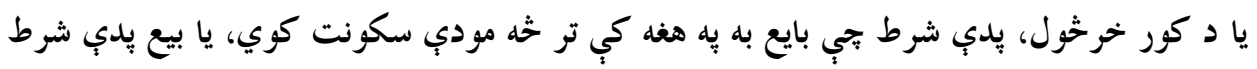

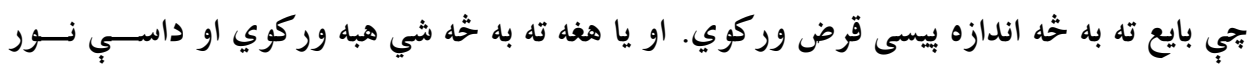

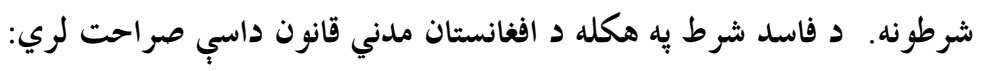

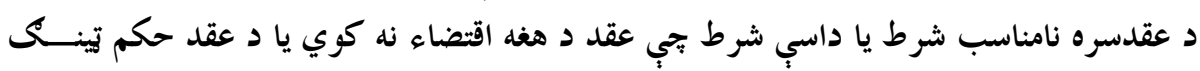

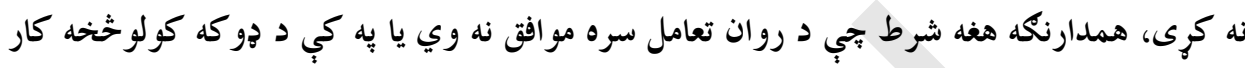

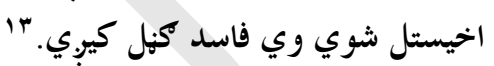

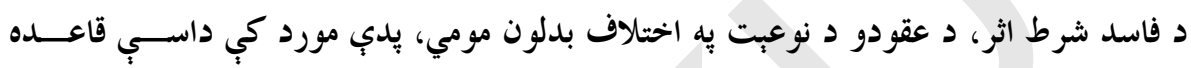

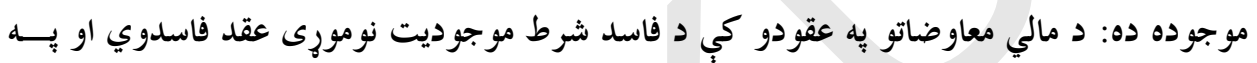
غير مالي عقودو كي يب نه فاسدوي.

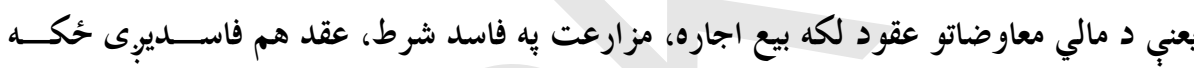

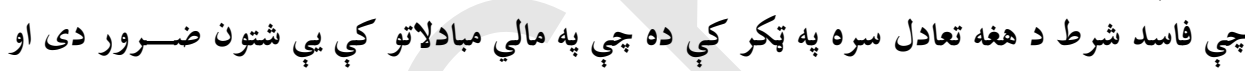

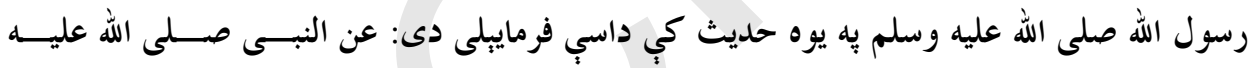
وسلم: انه نهى عن بيع و شرط. 10

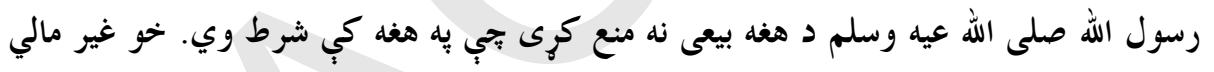

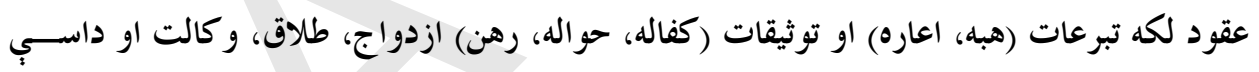

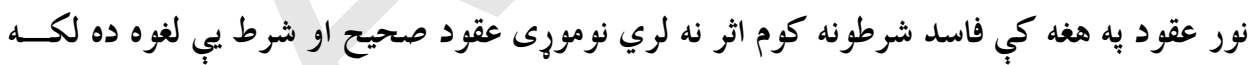

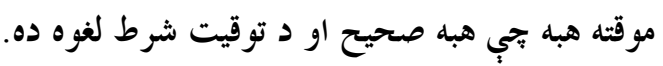

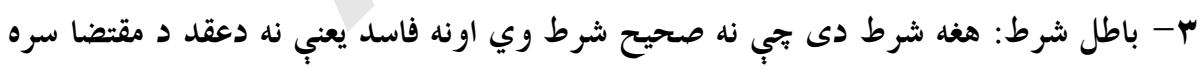

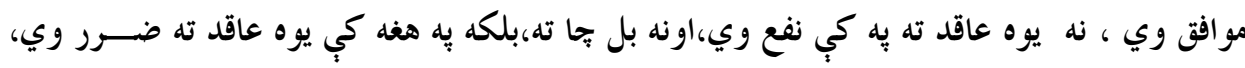

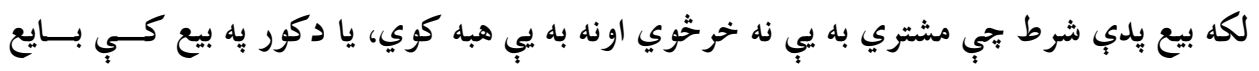

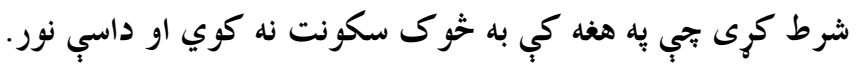

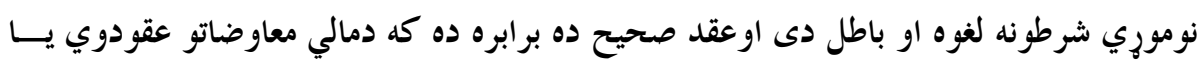

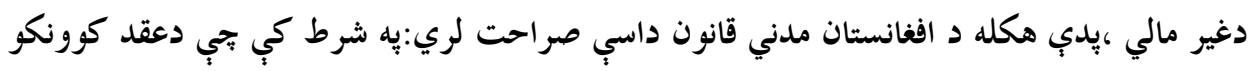

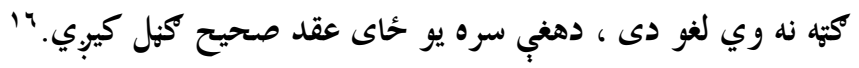




\section{دشرط به اره د حنبلي فقهاؤ دريخ:}

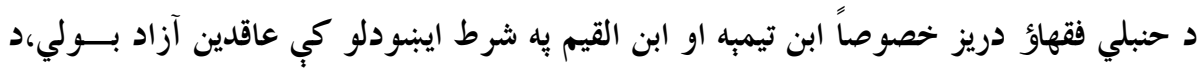

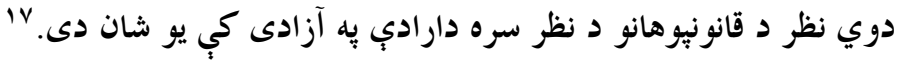

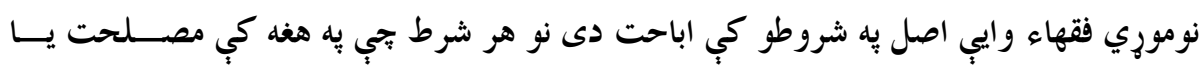

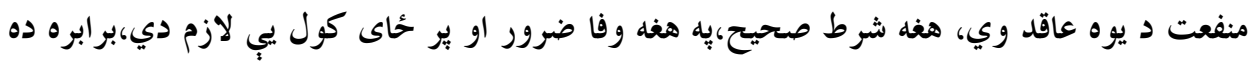

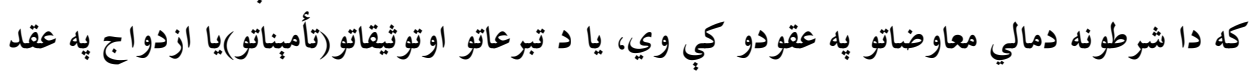
كي وي.

به نومورى عقودوكي كه به اينبودل شوي شرطونو باندي وفا ونه شي،اروند لورى ته د عقد د

$$
\text { فستخ كولو اختيارشته. }
$$

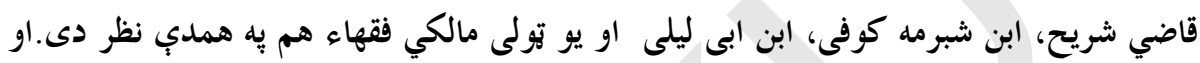

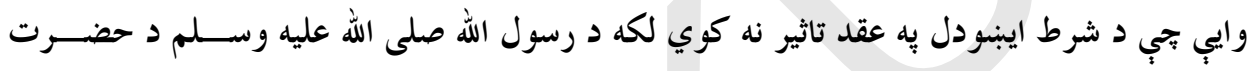

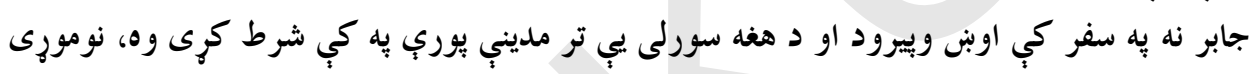

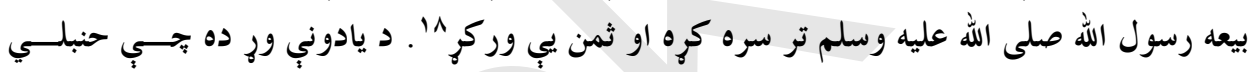
فقهاءهم دوه دوله شرطونه روا نه بولي:

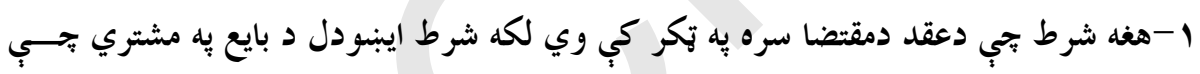

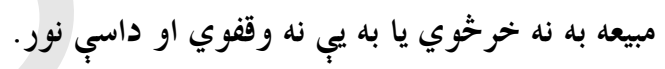

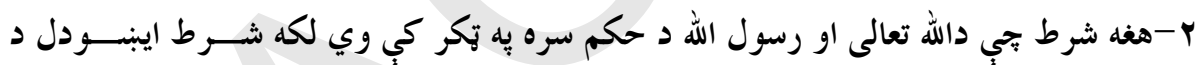

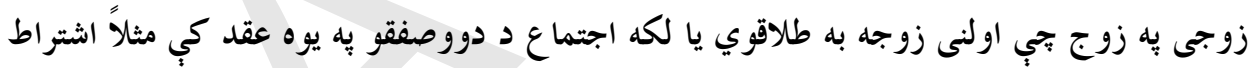

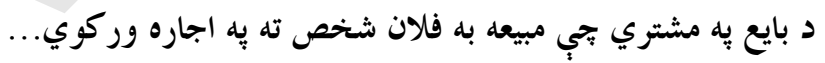

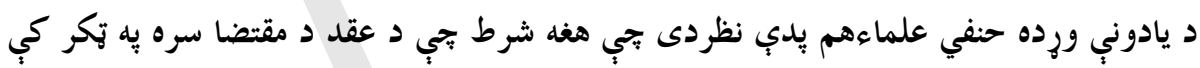

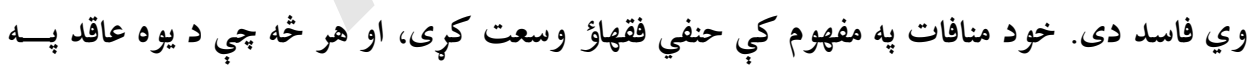

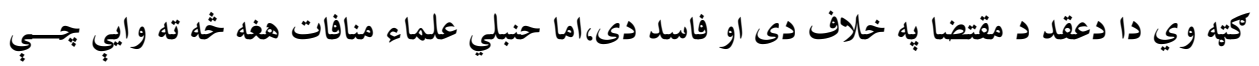

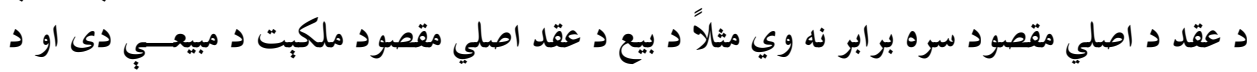

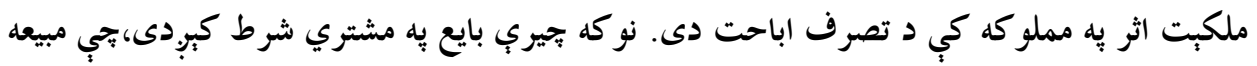

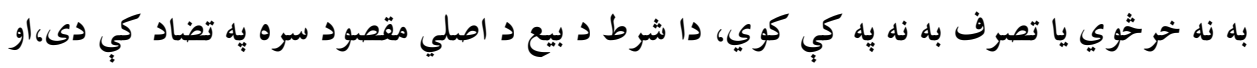

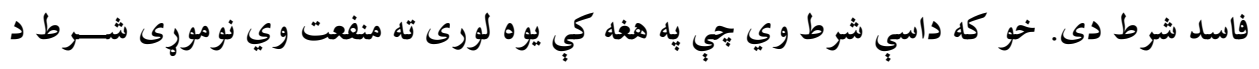


عقد د مقتضا سره مخالفت نه لري هغه صحيح ده لكه به بيع كي تر معين مودي يــوري د بـــايع د

$$
\text { سكنى شرط ايبنودل. }
$$

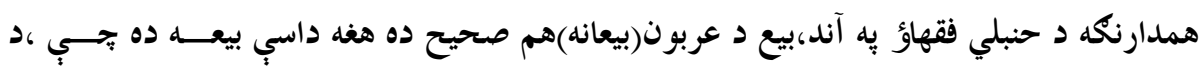

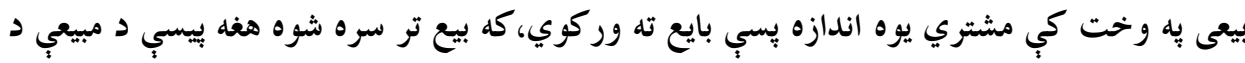

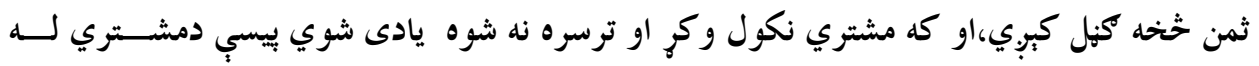

$$
\text { خوا بايع ته هبه كنبل كبرب. }
$$

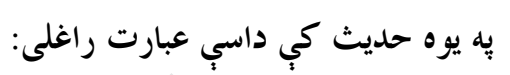

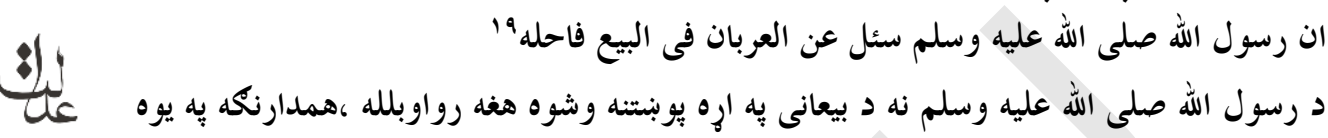

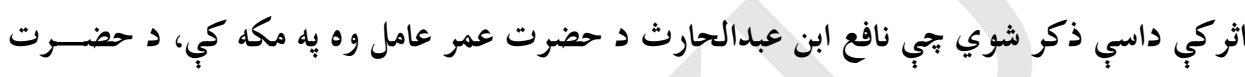

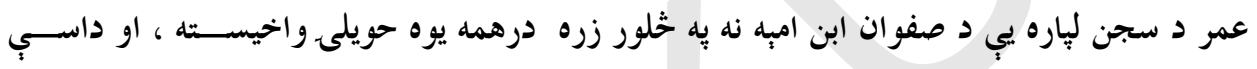

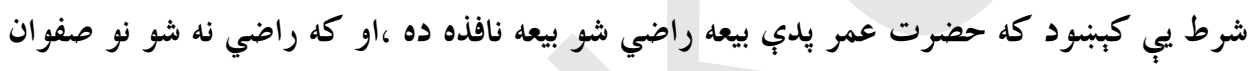

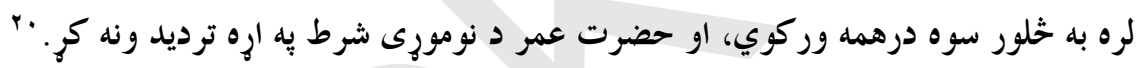

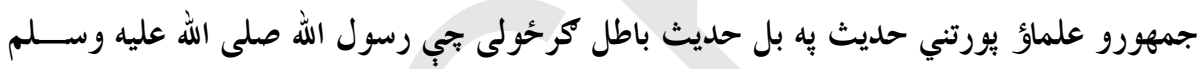

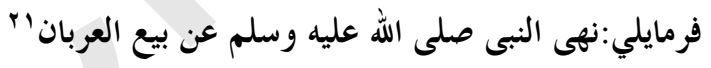

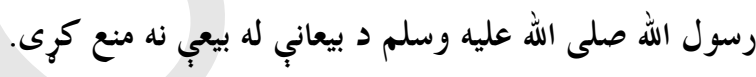

\section{د مطلق تصرفاتو تعليق، به شرط يوري:}

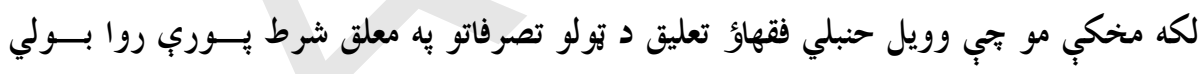

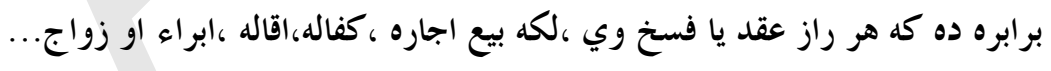

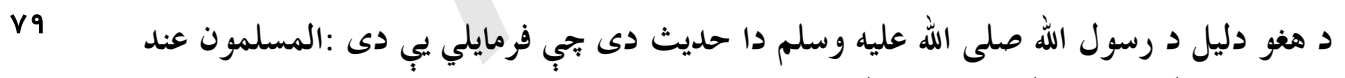

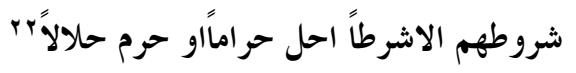

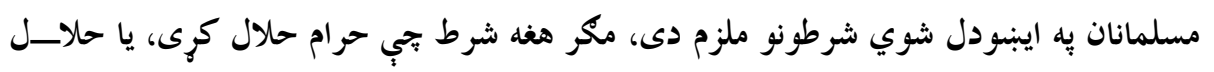

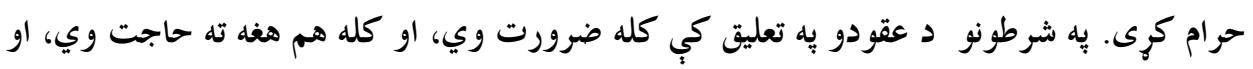

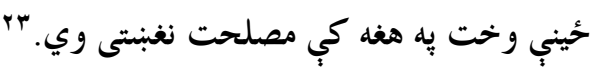




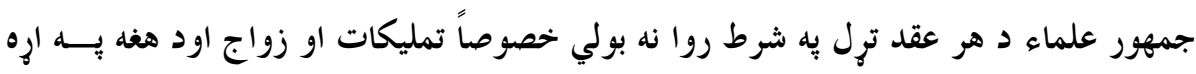

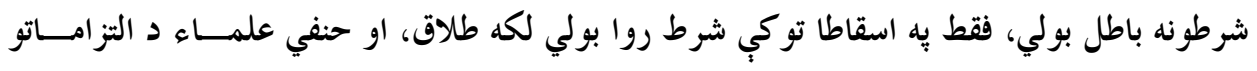

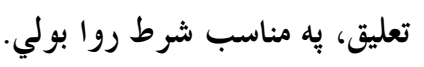

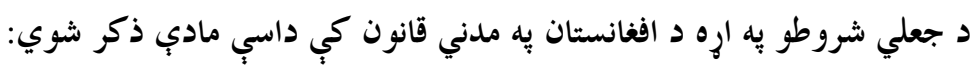

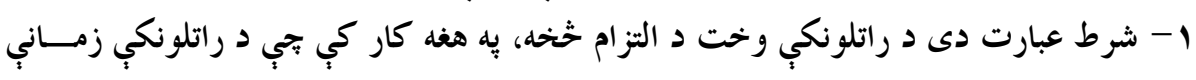

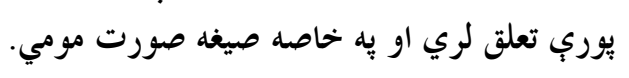

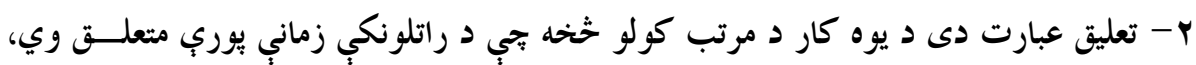

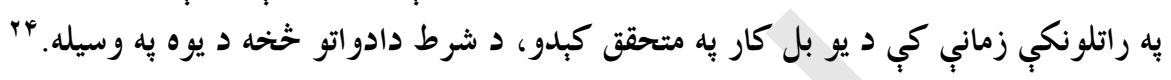

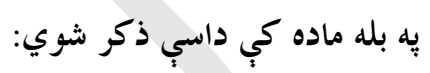

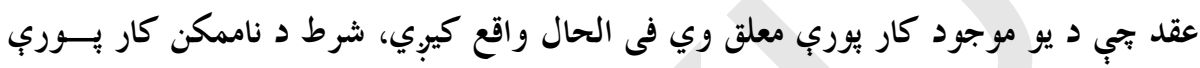

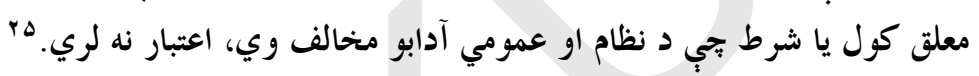

ماخدونه:

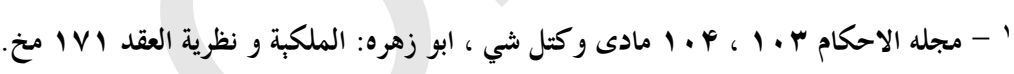

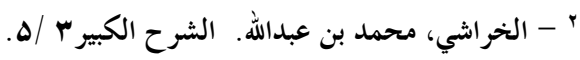

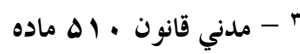

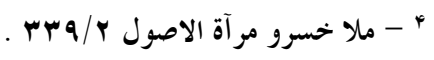

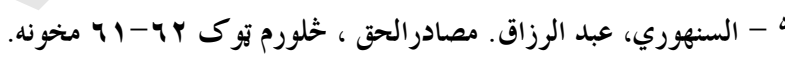

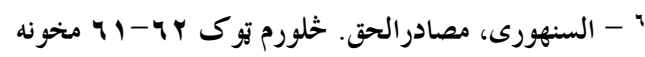

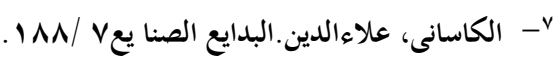

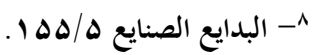

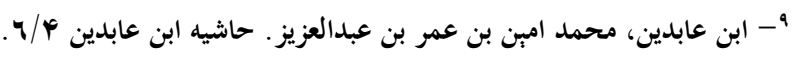

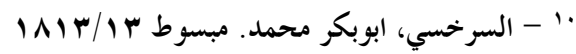

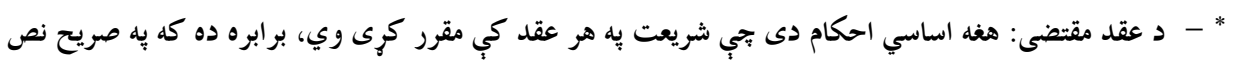

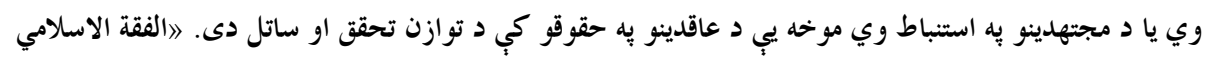




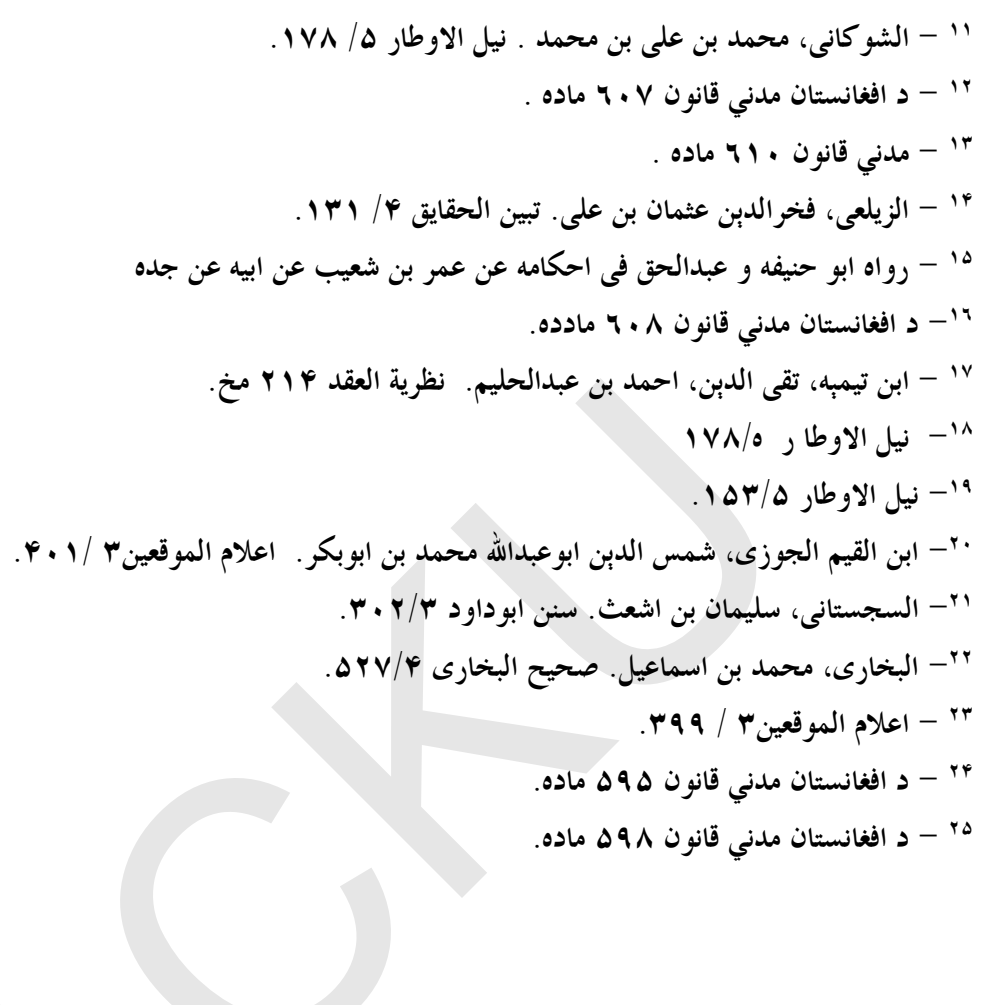




\section{كشور فنلند در راستاى اهداف بشر دوستانه}

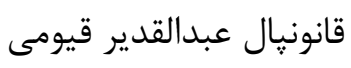

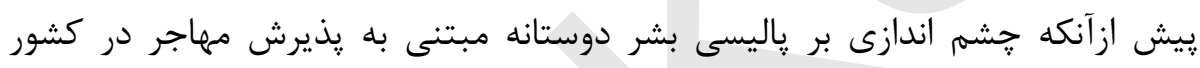

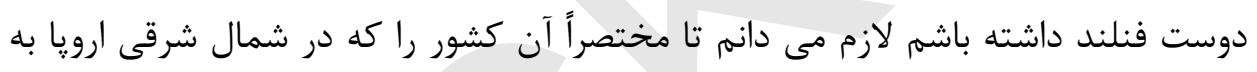

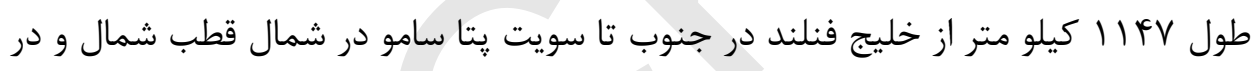

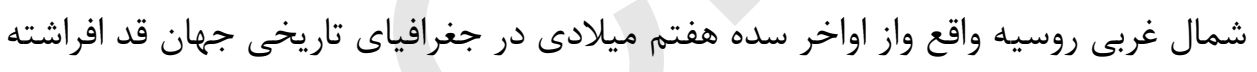

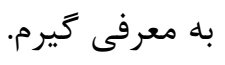

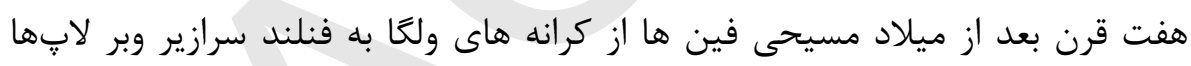

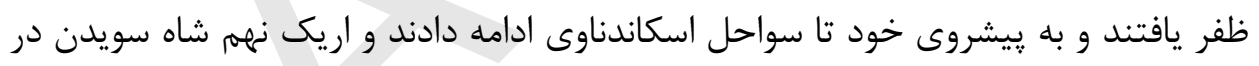

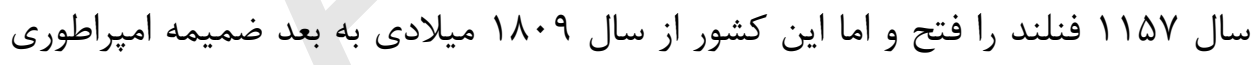

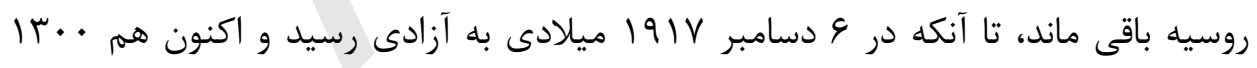

$$
\text { كيلو متر با روسيه تعلق مرزى دارد. تانس }
$$

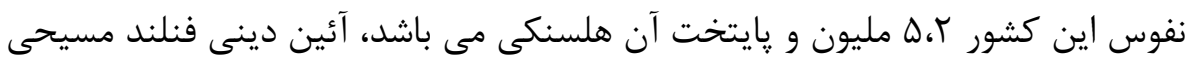

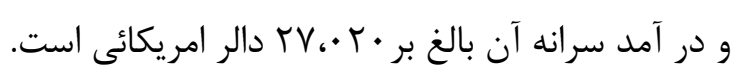

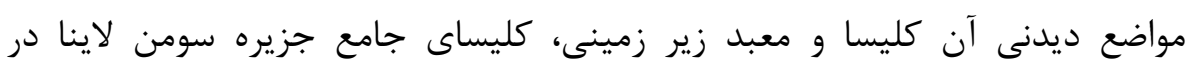

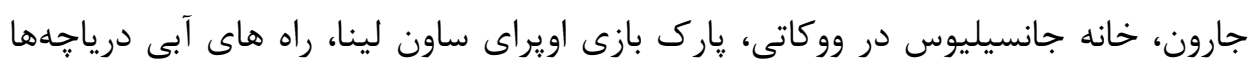

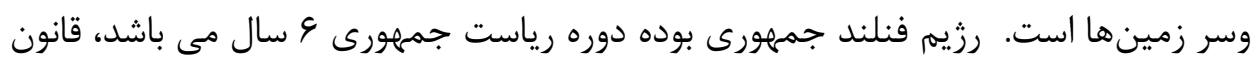

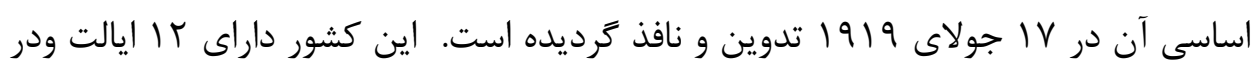


سول19 ميلادى به شوراى كمك هاى متقابل اقتصادى ييوسته است. گر جه مردم آن به زبان

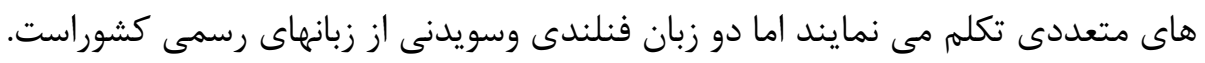

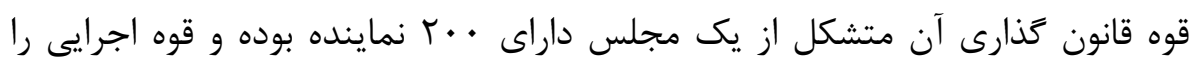

$$
\text { رئيس جمهور وشوراى دولتى بعهده دارد. }
$$

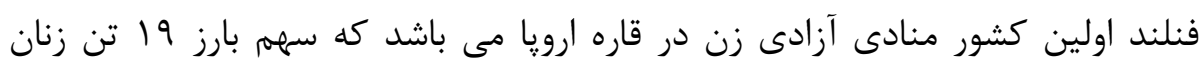

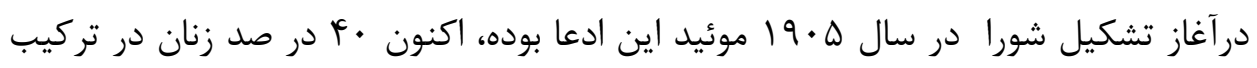

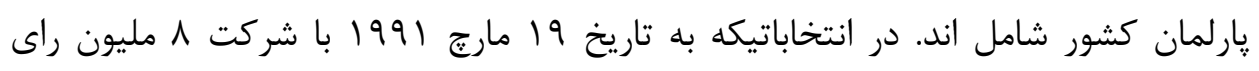

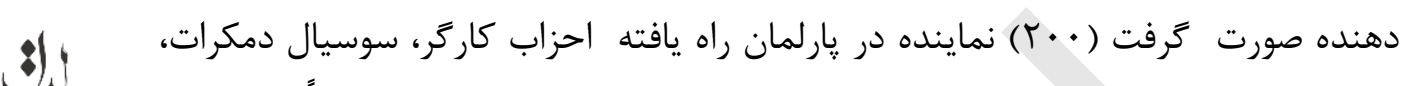

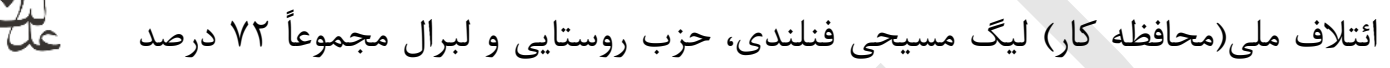
آراء را به دست آوردند. دفاع از حاكميت ملى وحراست تماميت اراضى را اتباع آن از وظايف خود مى داء دانداند،

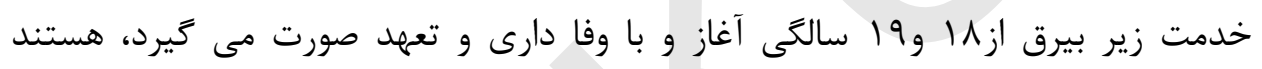

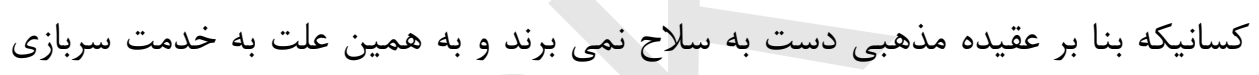

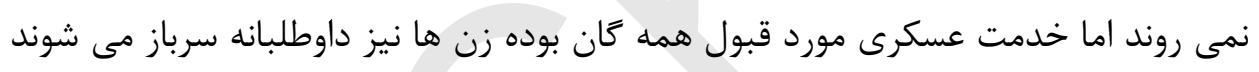
و در اجراى وظايف با مرد ها فرق ندارند.

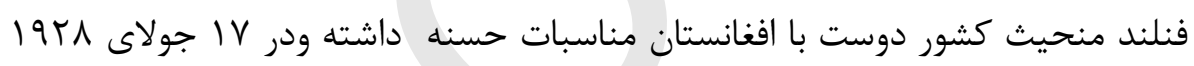

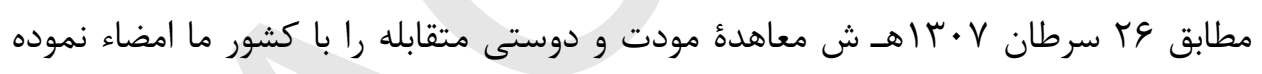

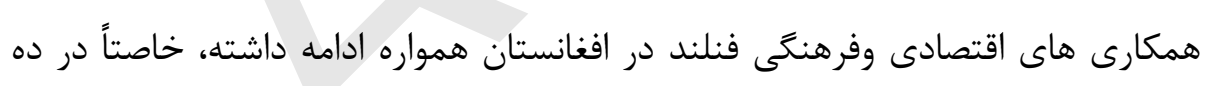

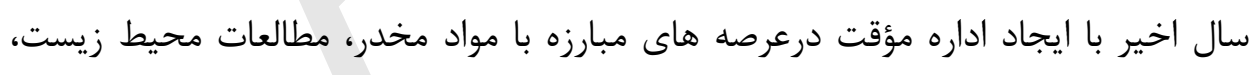

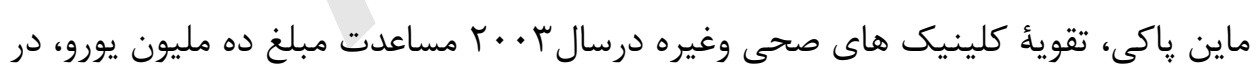

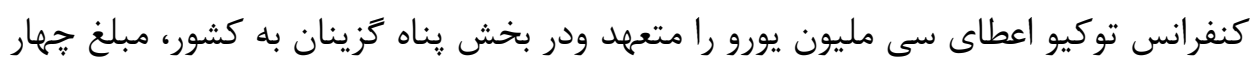

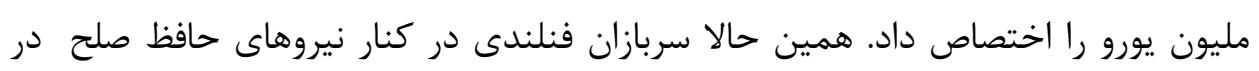
مبارزه عليه تروريزم در كشور ما شركت فعال دارند.

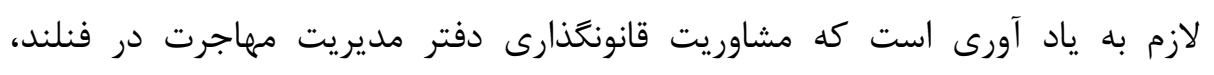

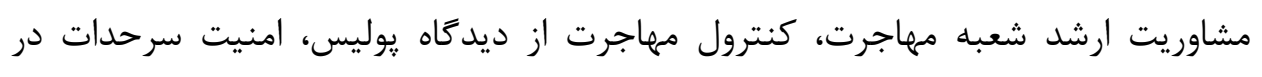

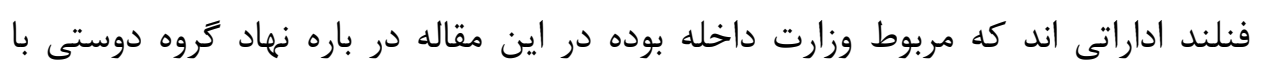


افغانستان، يارلمان فنلند، شهردارى(شار والى) مختصرى از وضع مهاجرين در ناحيه لاتى، مهئ

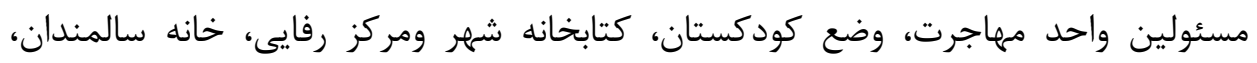

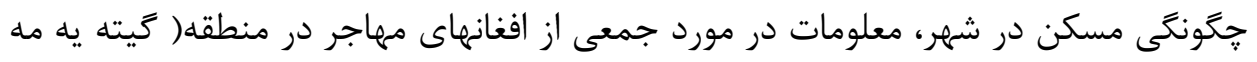

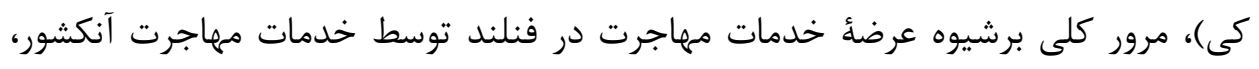

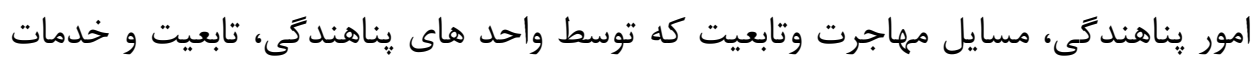

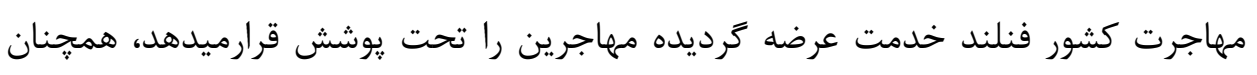

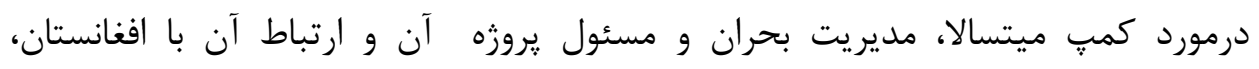

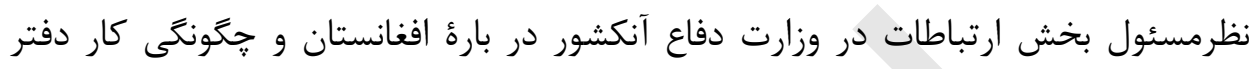
i.o.m

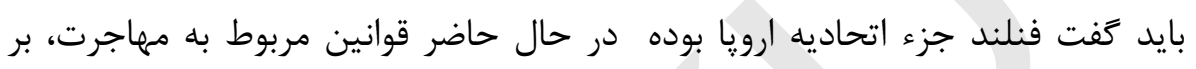

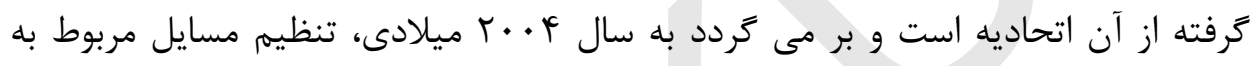

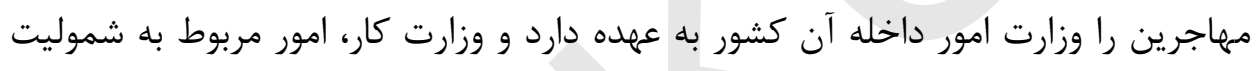

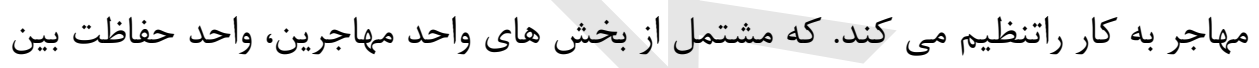

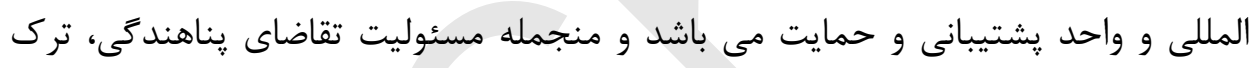

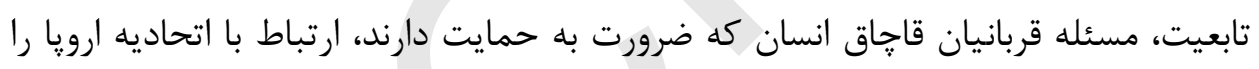

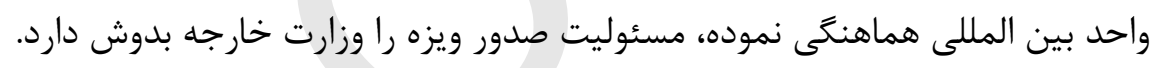
در حال حاضر بيشترين مهاجرين درفنلند از كشورهاى سويدن، استونيا، جين، هين،

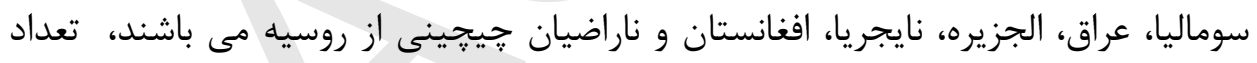

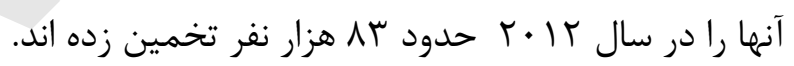

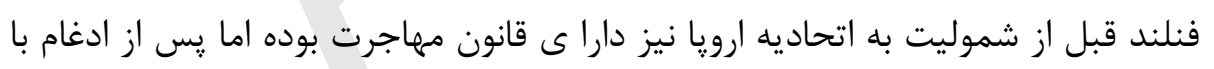

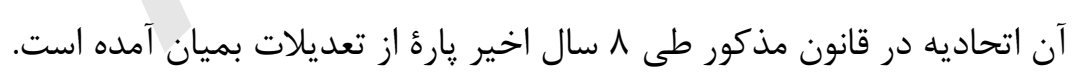

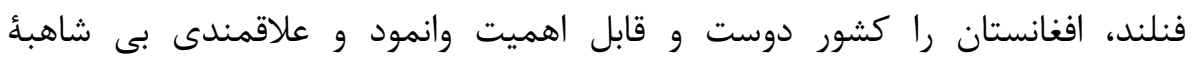

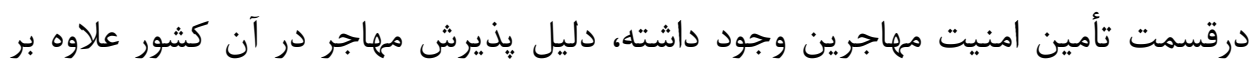

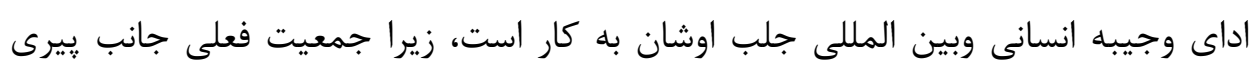

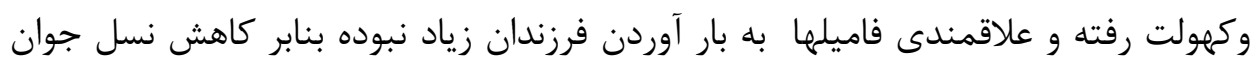

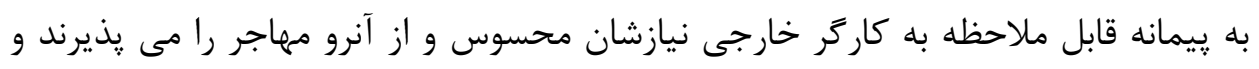

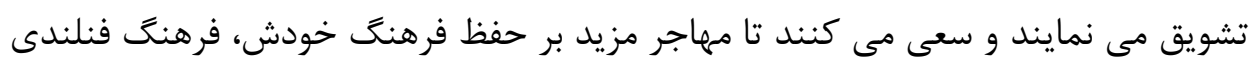


را نيز بيذيرد، جنانجه جهت تحقق اين هدف با يك عده كشورها خواستار عقد موافقتنامه ها

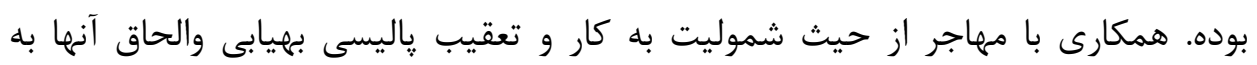

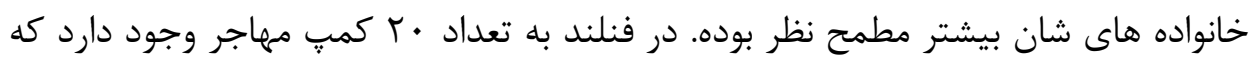

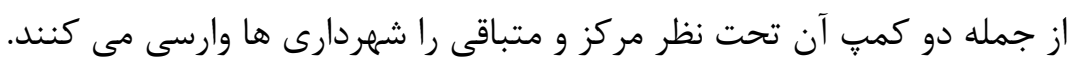

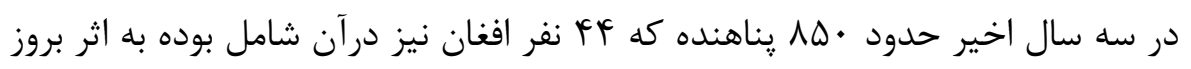

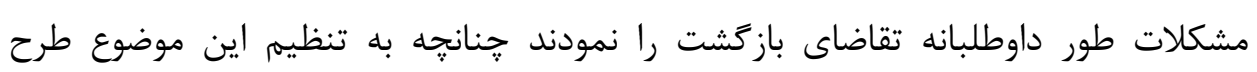

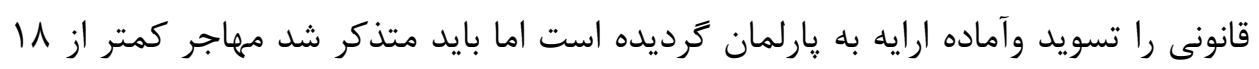

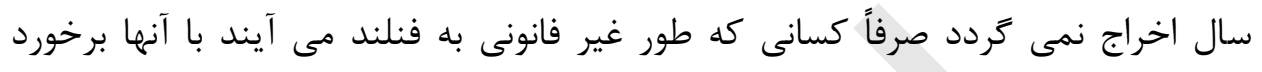
قانونى صورت مى كيرد. قانون تابعيت در فنلند در مقايسه با قانون مهاجرت ماتود سابقه زيادترى دارد، تابعيت آنكشور

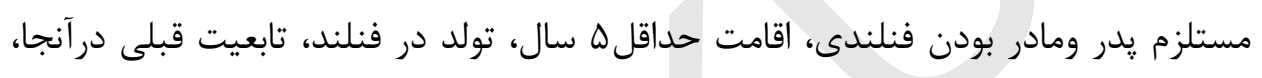

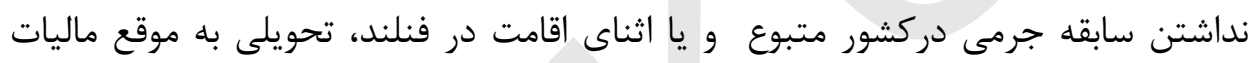

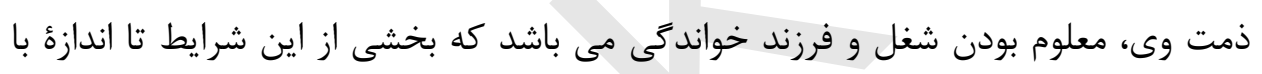
قانون تابعيت كشور ما همخوانى دارد.

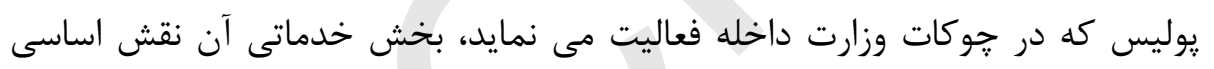

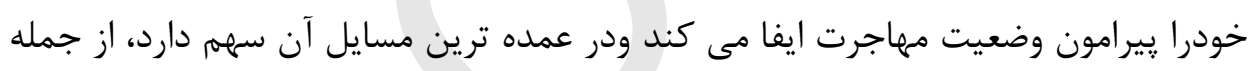

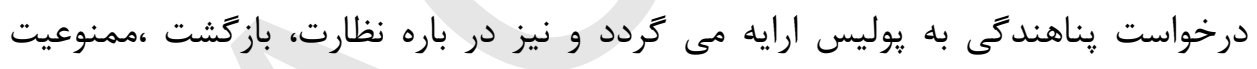

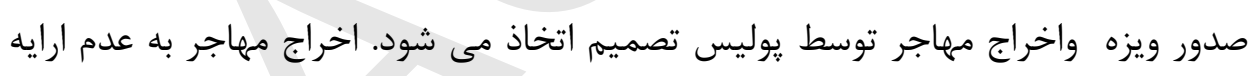
دليل معقول مهاجرت و ارتكاب جنايت، مربوط مى بـ باشد.

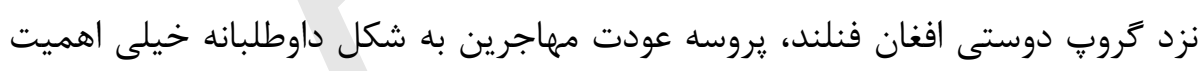

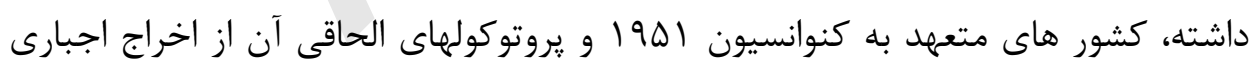

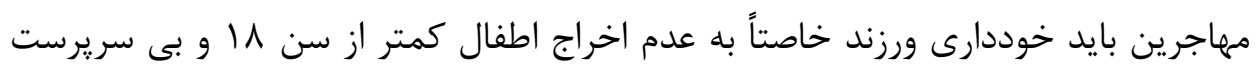

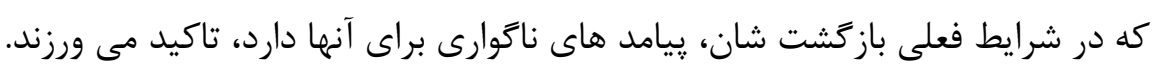

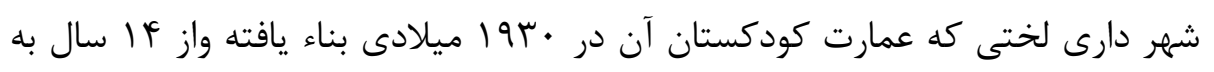

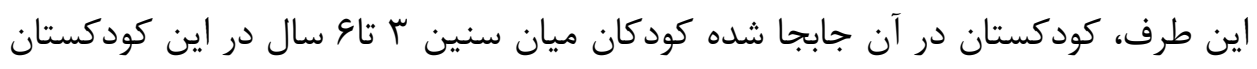

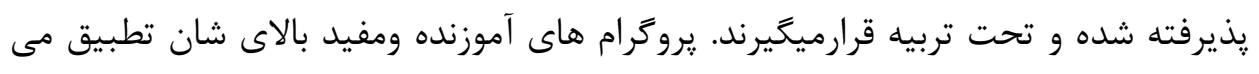

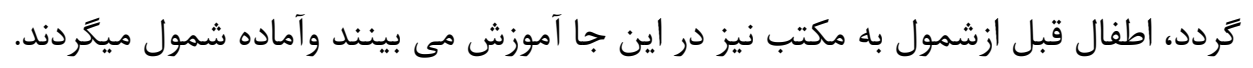


در سال سوا9 قانون كودكستان در اين كشور وضع شده كه به موجب آن امور مربوط به

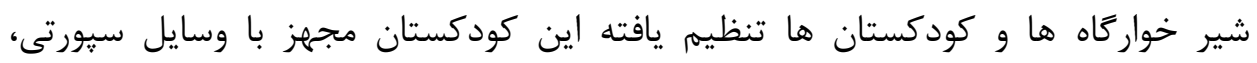

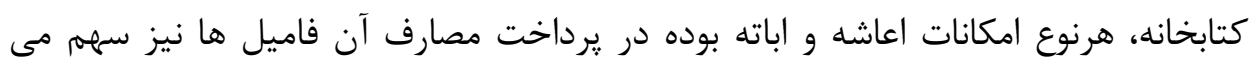

$$
\text { گيرند. }
$$

اطفال مهاجر را يس از سه سالكى در كو دكستان ها مى يذيرند، نخستين كار آمو زش از

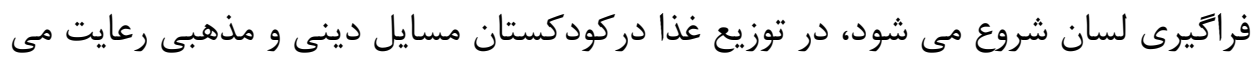

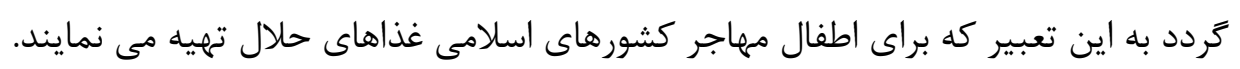

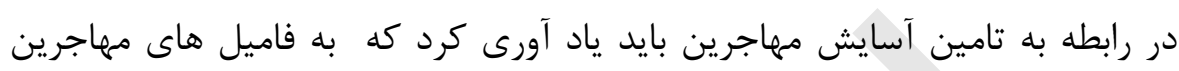

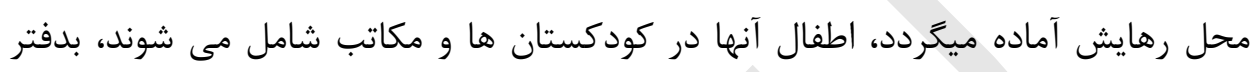

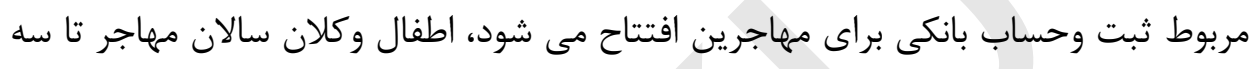

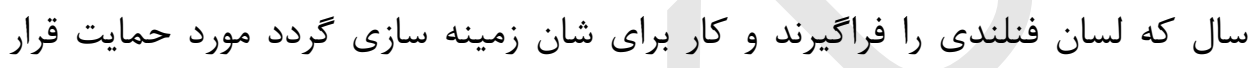

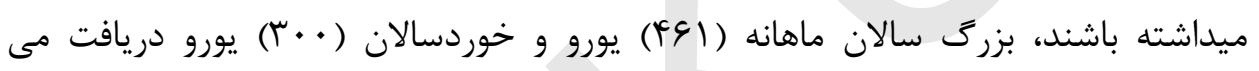
در اين كشور به عقايد وسنن مهاجرين ارج كذاشته مى شود جنانجه درناحيه كيته يه مه

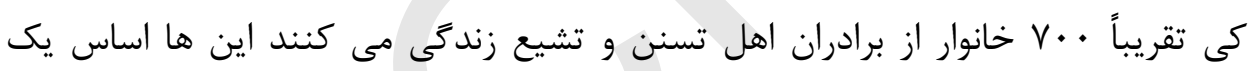

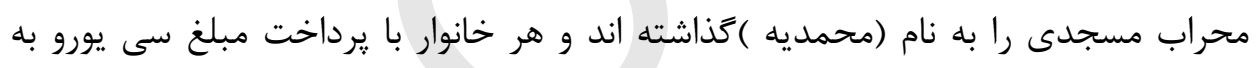

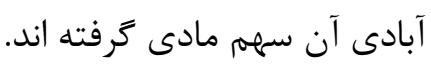

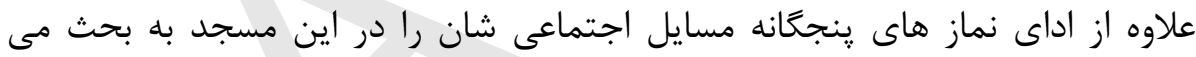

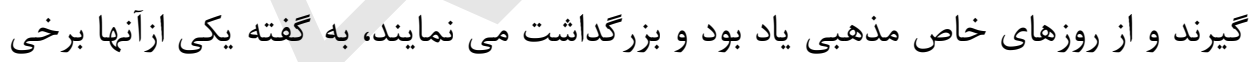

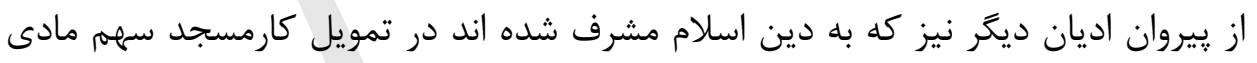
كرفته اند.

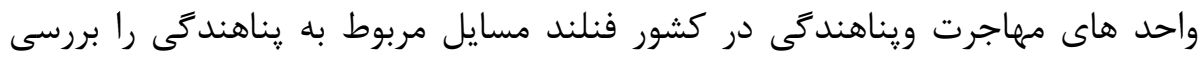

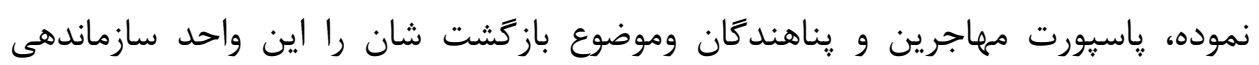

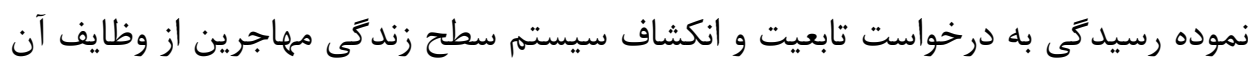

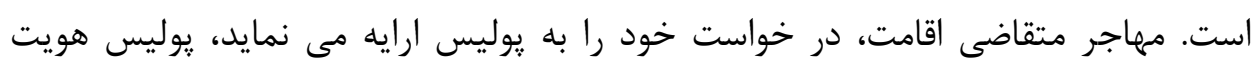

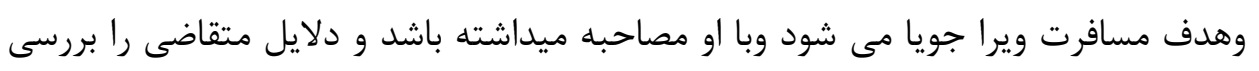

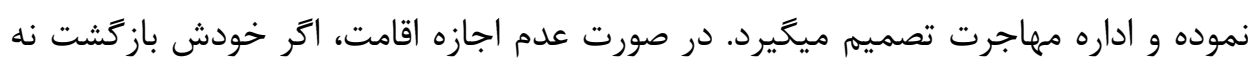


نمود، ذريعه يوليس اخراج ميكردد. اما بيشتر سعى مى شود تا مهاجر خانس اجازه اقامت نوع

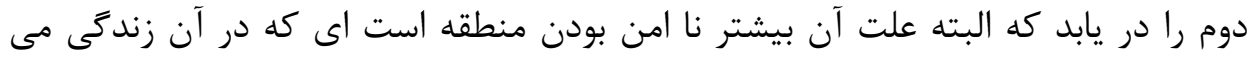

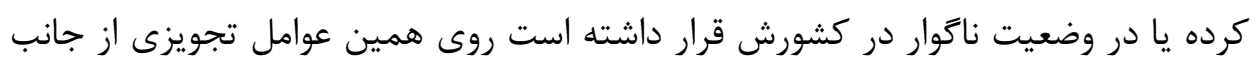

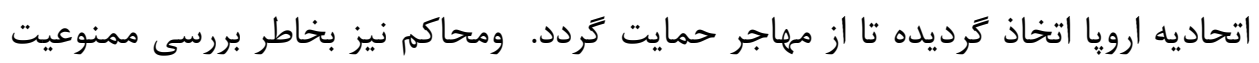

$$
\text { بركرداندن آنها تشكيل مى يابد. }
$$

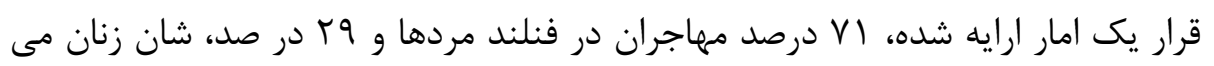

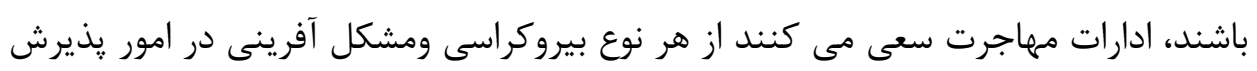

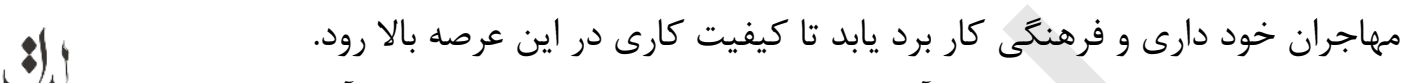

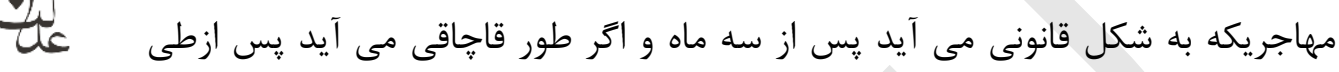
مراحل لازمه بعد از شش ماه اجازه كار حاصل مى كى كند.

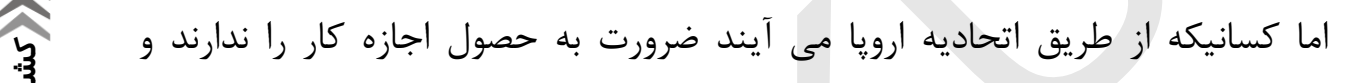

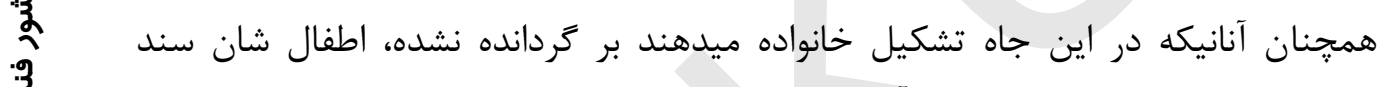

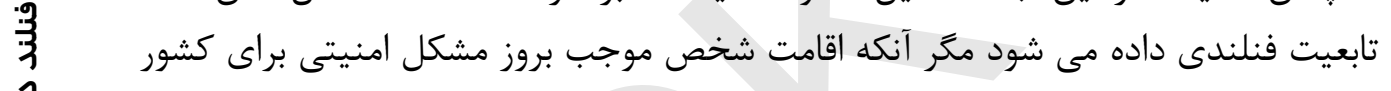

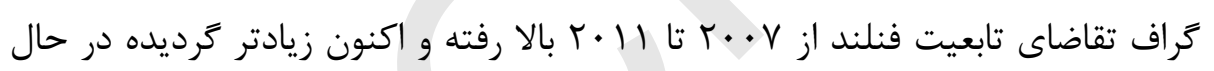

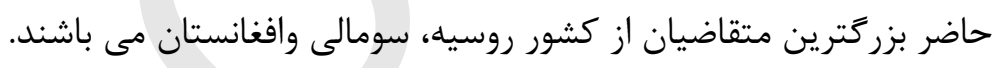

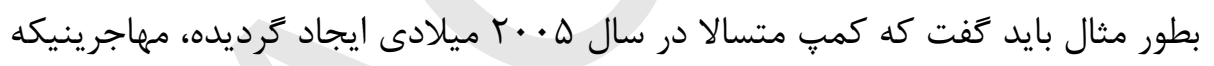

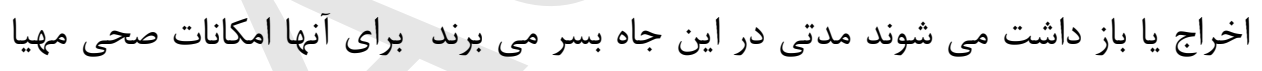

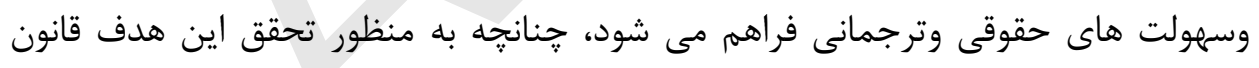

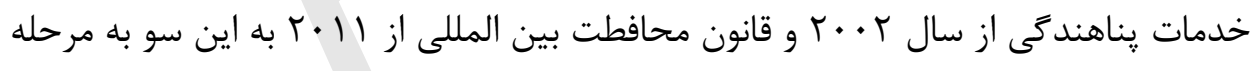

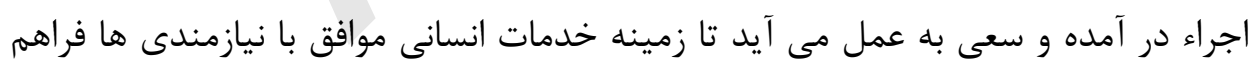

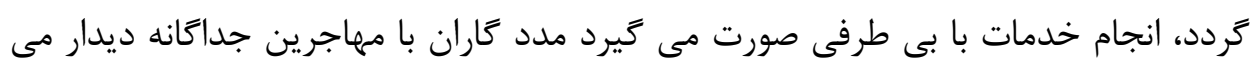

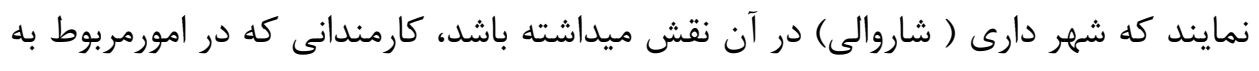

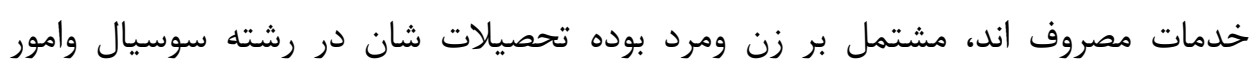

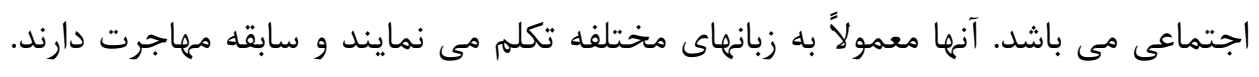

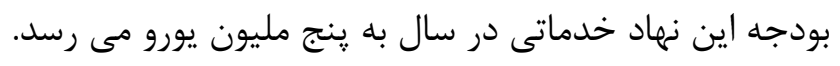


كه هدف كلى آن حل مخاصمات و جلوكيرى از دركيرى ها مى باشد، درسال

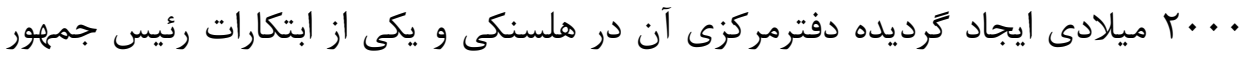

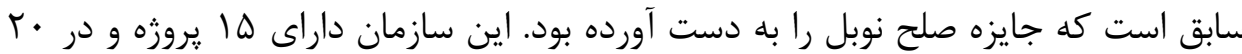
كشور نمايندگى دارد، بودجه اين نهاد سالانه هفت مليون يورو و توسط اتحاديه ارويا و ساير منابع خيريأ تمويل مى شود. گرجه حل در گيرى بايد طور سنتى و از طريق دولت ها عملى

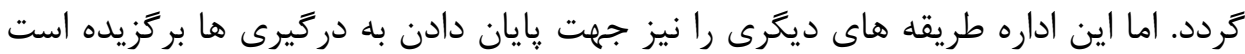

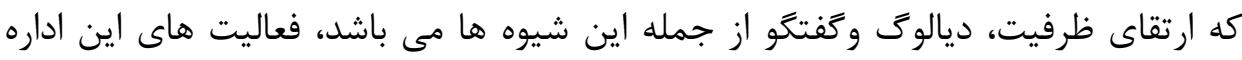

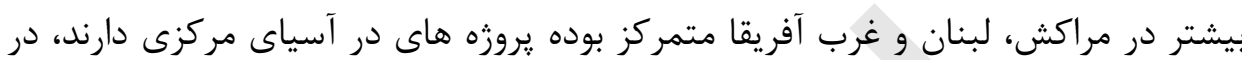

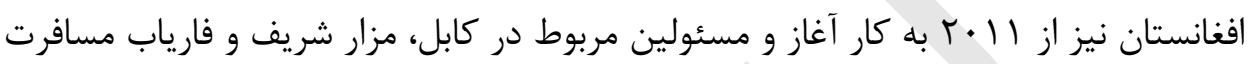
هاى داشته اند، به عقيده آنها رسيدن به صلح وابتكار عمل وابسته به سعى و تلاش خود آنا

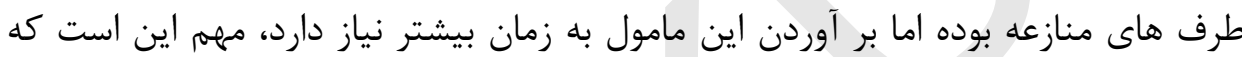

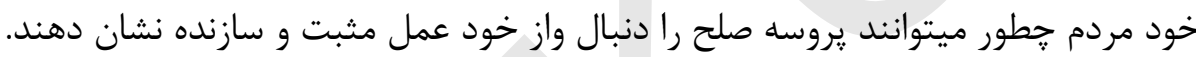

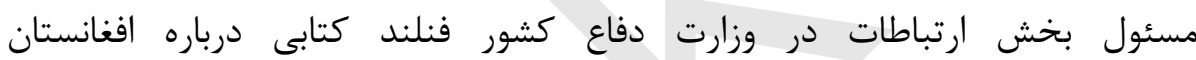

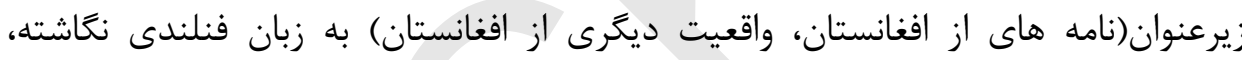

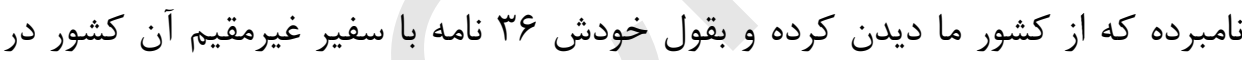
افغانستان رد و بدل نموده، واقعيت هاى را كه در باره كشور ما انعكاس داده در اين كتاب

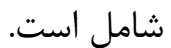

به نظراو كمك ها در بخش انكشافى خاصتاً ساختار هاى زير بنائى براى كشورما خيلى

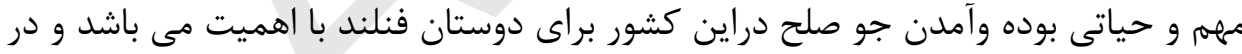

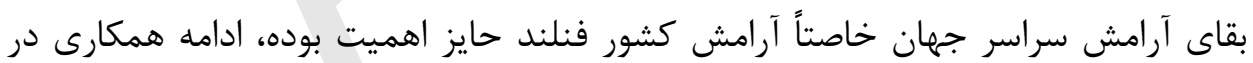

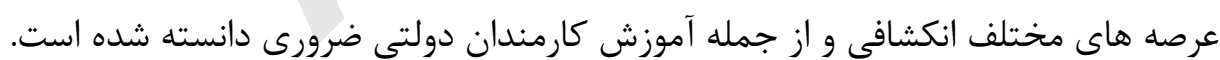

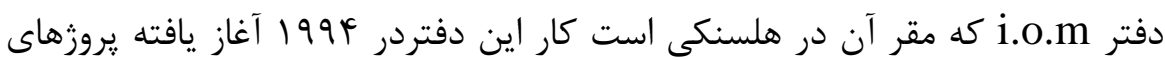

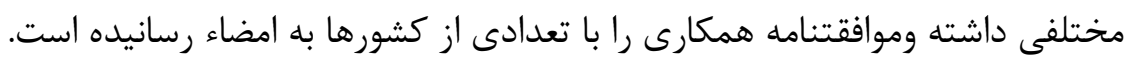

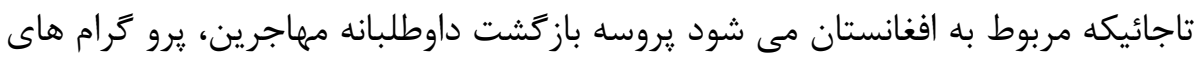

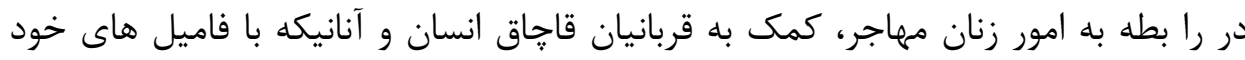

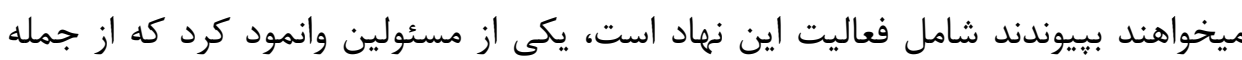

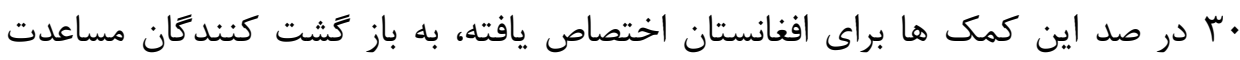


هاى نقدى مى كردد. وقتى از مسوولين درباره اخراج مهاجر ين سوال شد معلومات دادند كه دإنه

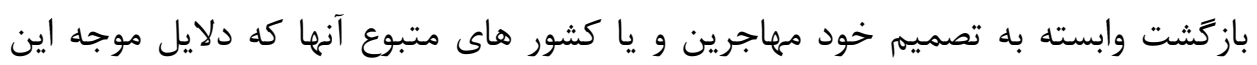

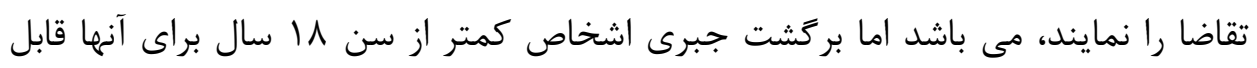

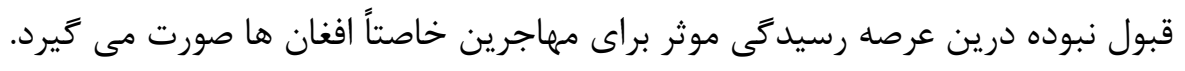

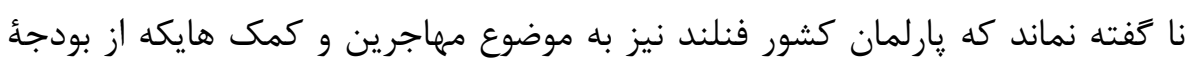

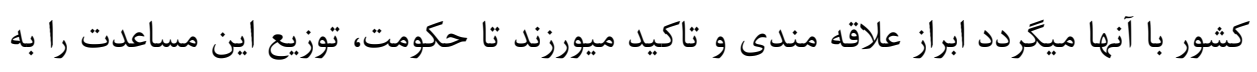

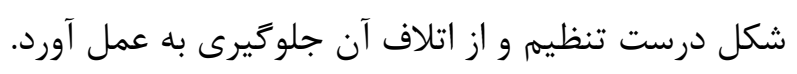

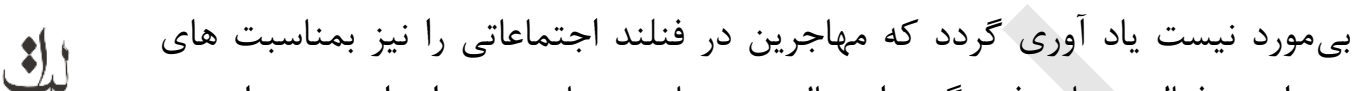

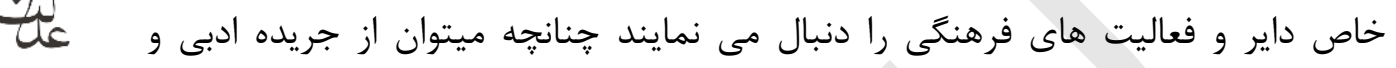

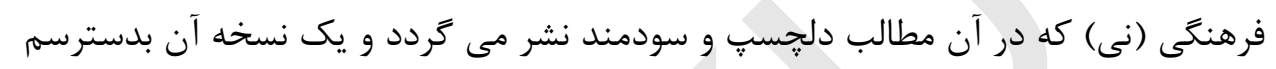
رسيده، ياد آورى كرد.

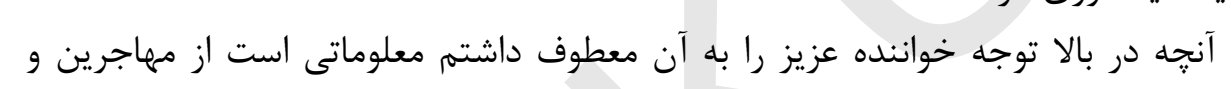

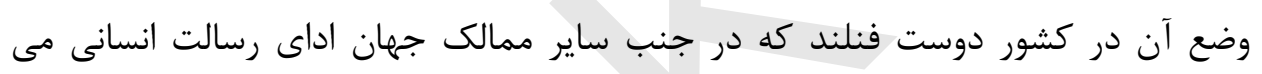

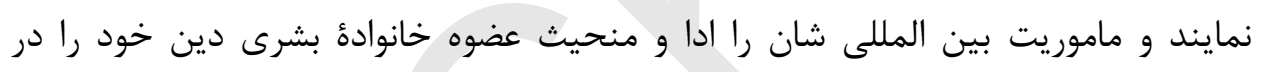

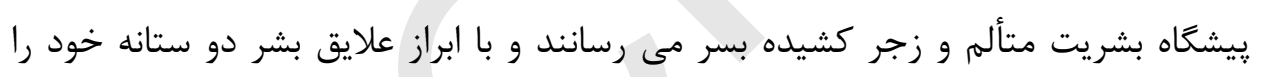

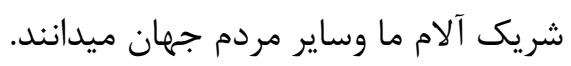

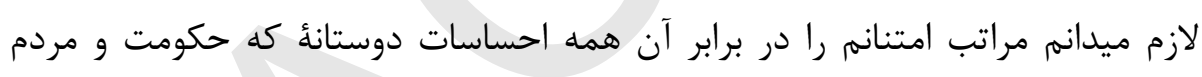

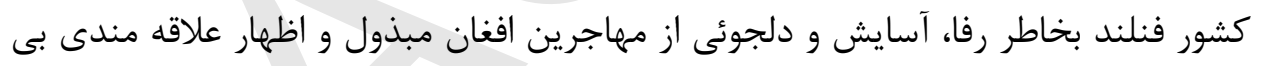

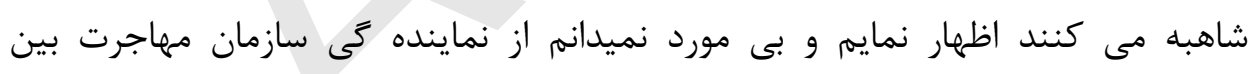

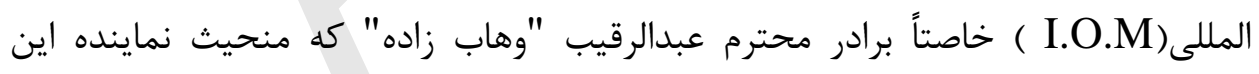

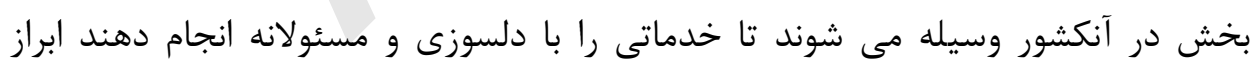
تشكر وقدر دانى نمايم. 


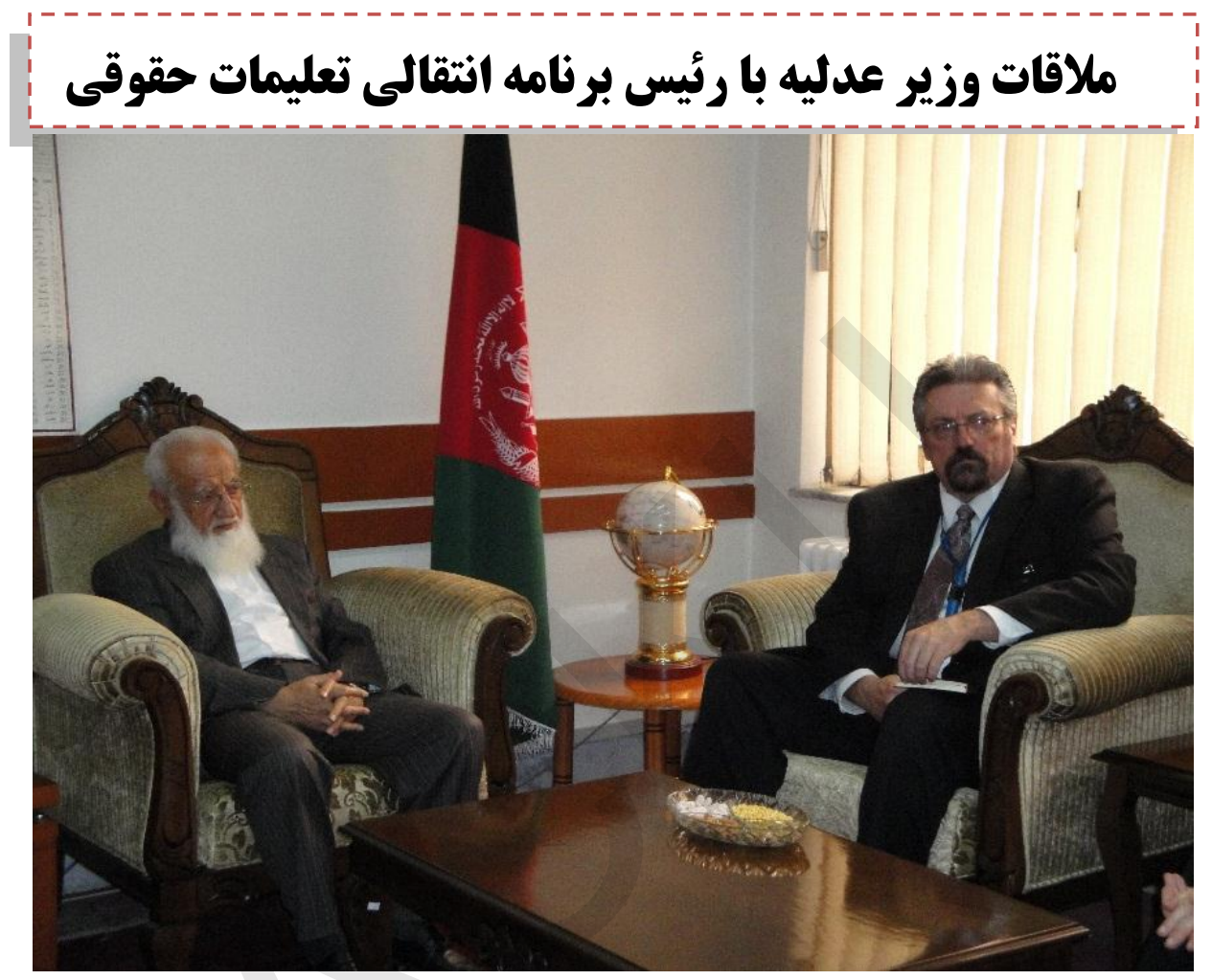

خارنيوه حبيب الله (غالب) وزير عدليه دولت جمهـورى اسـلامى افغانسـتان روز دو شـنبه

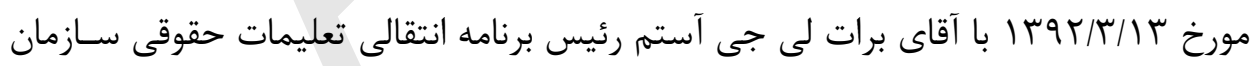

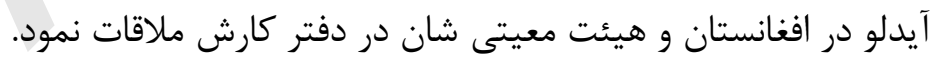

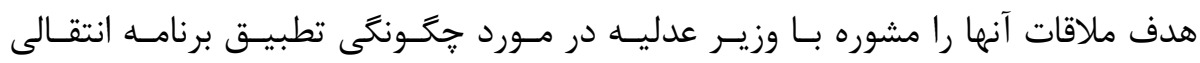
تعليمات حقوقى در وزارت عدليه تشكيل ميداد.

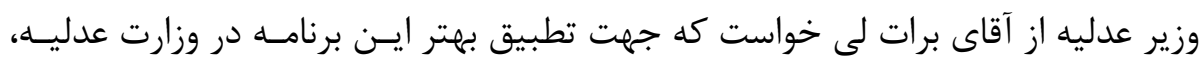
در قدم نخست رياست عمومى تقنين وزارت عدليه را تقويه نموده و سطح دانش مسلكى آنى آنها را ارتقاء ببخشند. 
وزير عدليه از آنها خواست كه ابتدا يك ارزيابى كلـى از رياسـت عمـومى تقنـين، كميتــه

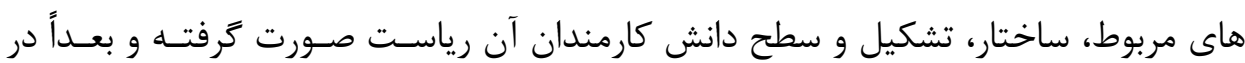
جهت ارتقاى سطح دانش آنها اقدام صورت كيرد تا آنها بتوانند ساير كارمنـدان وزارت عدليــانهـ را آموزش دهند.

در اخير وزير عدليه از رئيس برنامه انتقالى تعليمات حقوقى جهت ايجاد يك نهاد تعليمى داند

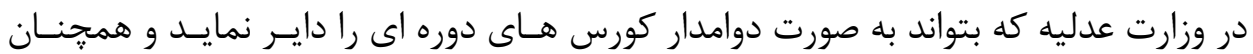

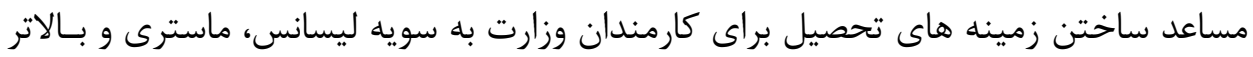

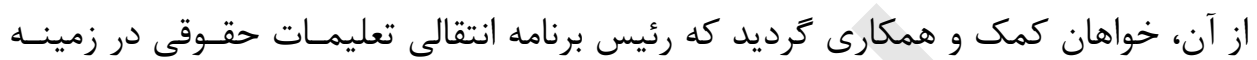




\section{ملاقات وزير عدليه با رئيس بخش حاكميت قانون ماموريت}

بوليس اتحاديه ارويا در اففانستان

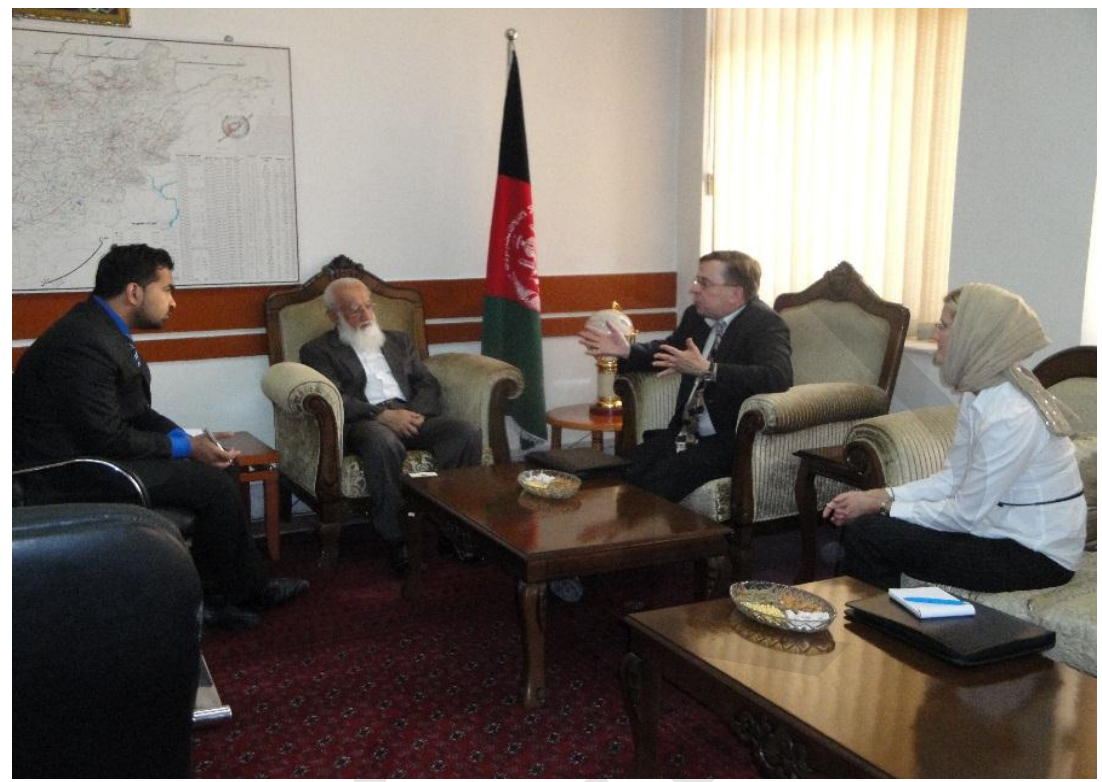

خارنيوه حبيب الله غالب وزير عدليه دولت جمهورى اسلامى افغانستان روز دوشنبه مورخ • ارويا در افغانستان (UPOL) در دفتر كارش ديدار و كفتخو نمود. ابتدا آقاى هايكى وندروف از خدمات كه در بخش حاكميت قانون با ادارات عدلى و قضايى افغانستان انجام داده اند ياد آورى نمود. خصوصاً با وزارت عدليه كه در تهيه كد جزايى (penal cod ) و آكاهى حقوقى عامه نيز همكارى نموده اند.

وى همجنان كفت كه ما در هماهنگى برنامه هاى اولويت ملى نيز نقش خود را ايفا ميكنيم و از وزير عدليه خواست كه اتر كدام سفارشى درين مورد داشته باشند با آنها در ميان بخذارند.

وزير عدليه از اهميت قانون در يك جامعه ياد آورى نموده فرمود: در حاكمت قانون تسويد، تدقيق، تصويب و بالاخره توشيح قانون در يك جامعه ارزش بارز داشته و در حقيقت 
اساس حاكميت قانون در يك جامعه را قانون جامع، همعانى و بدون در نظر داشت كدام

$$
\text { ملحوظ سياسى، تشكيل ميدهد. }
$$

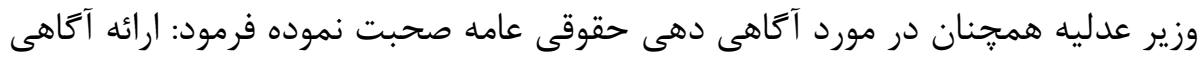

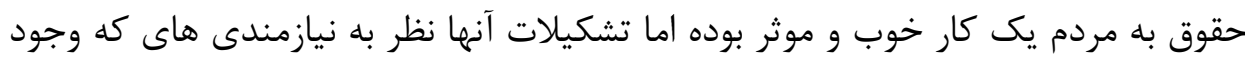

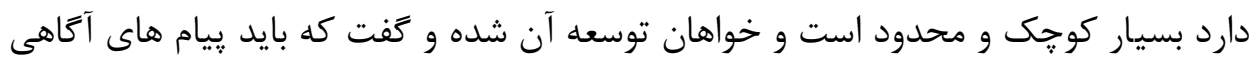

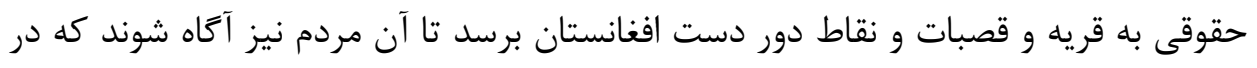

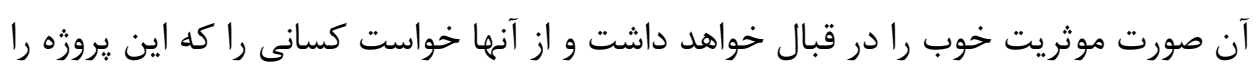

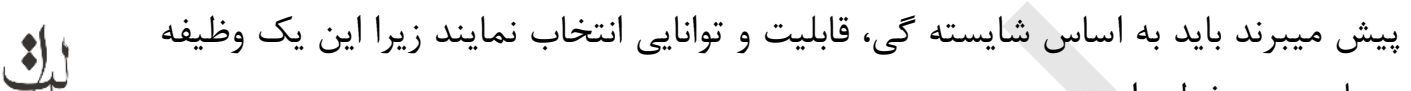
بسيار مهمم و خطير است.

وى همجنان كفت: موضوعات كه به آكاهى مردم رسانده ميشود بايد مطابق به فرهنَ،

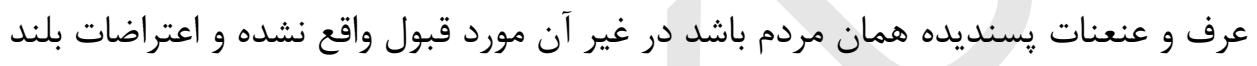

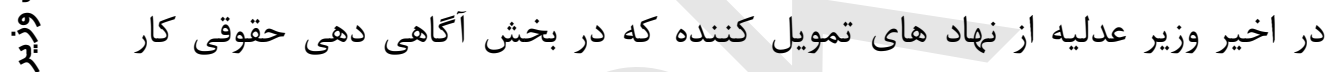

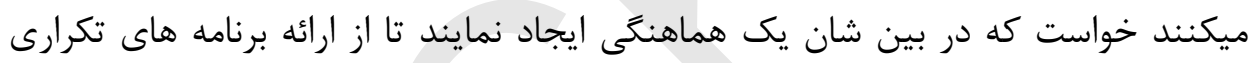

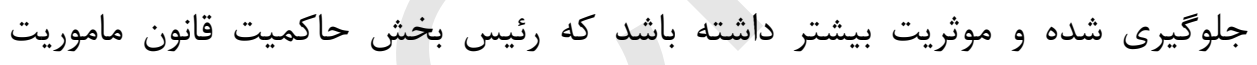

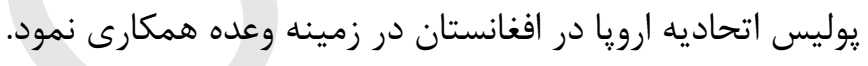

منبع: آمريت مطبوعات 
